FACULDADE DE ARQUITETURA E URBANISMO

UNIVERSIDADE DE SÃO PAULO

\title{
DESIGN E ARQUITETURA: \\ A CRIANÇA E AS BIBLIOTECAS PÚBLICA INFANTILE ESCOLAR
}

ALINE PESSOA DE OLIVEIRA AMORIM

SÃO PAULO 2017 
AUTORIZO A REPRODUÇÃO E DIVULGAÇÃO TOTAL OU PARCIALDESTE TRABALHO, POR QUALQUER MEIO CONVENCIONAL OU ELETRÔNICO, PARA FINS DE ESTUDO E PESQUISA, DESDE QUE CITADA A FONTE.

Catalogação na Publicação

Serviço Técnico de Biblioteca

Faculdade de Arquitetura e Urbanismo da Universidade de São Paulo

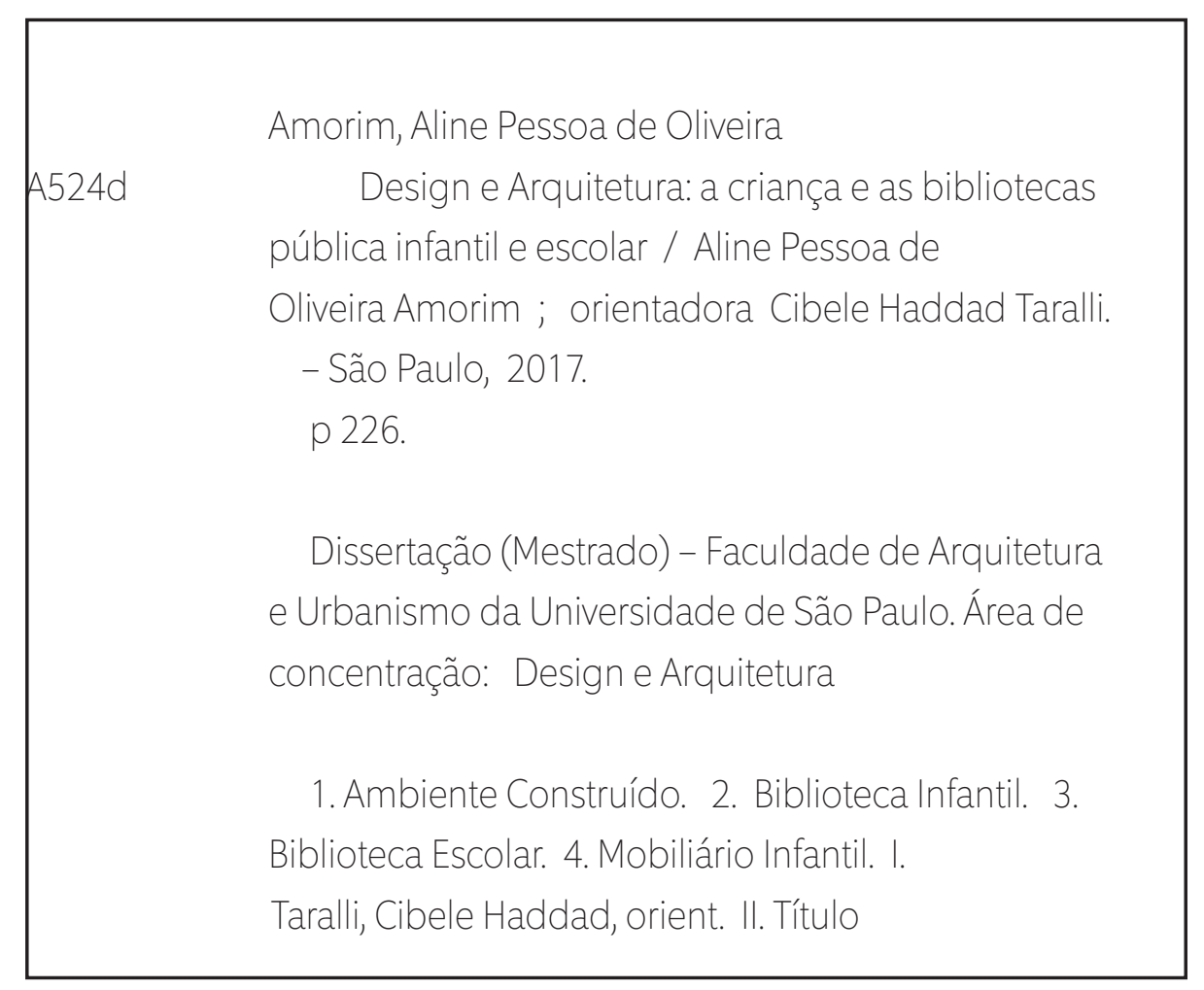




\section{DESIGN E ARQUITETURA: A CRIANÇA E AS BIBLIOTECAS PÚBLICA INFANTILE ESCOLAR}

DISSERTAÇÃO APRESENTADA AO PROGRAMA DE PÓS-GRADUAÇÃO EM ARQUITETURA E URBANISMO DA UNIVERSIDADE DE SÃO PAULO PARA OBTENÇÃO DO GRAU DE MESTRE

ÁREA DE CONCENTRAÇÃO: DESIGN E ARQUITETURA

\section{VERSÃO CORRIGIDA}

ALINE PESSOA DE OLIVEIRA AMORIM

ORIENTADORA: PROFA. DRA. CIBELE HADDAD TARALLI

EXEMPLAR REVISADO E ALTERADO EM RELAÇÃO À VERSÃO ORIGINAL, SOB RESPONSABILIDADE DA AUTORA E ANUẾNCIA DA ORIENTADORA. O ORIGINAL SE ENCONTRA DISPONÍVEL NA SEDE DO PROGRAMA SÃO PAULO, 11 DE JUNHO DE 2017 


\section{DESIGN E ARQUITETURA: A CRIANÇA E AS BIBLIOTECAS PÚBLICA INFANTILE ESCOLAR}

ALINE PESSOA DE OLIVEIRA AMORIM

DISSERTAÇÃO APRESENTADA AO PROGRAMA DE PÓS-GRADUAÇÃO EM ARQUITETURA E URBANISMO DA UNIVERSIDADE DE SÃO PAULO PARA

OBTENÇÃO DO GRAU DE MESTRE

APROVADA EM: 03/05/2017

BANCA EXAMINADORA

PROFA. DRA. CIBELE HADDAD TARALLI

INSTITUIÇÃO

JULGAMENTO

ASSINATURA

PROFA. DRA. ÁGATA TINOCO

INSTITUIÇÃO

JULGAMENTO

ASSINATURA

PROFA. DRA. TERESA MARIA RICCETTI

INSTITUIÇÃO

JULGAMENTO

ASSINATURA 
Para minhas avós, muito amadas, sempre vivas em minha memória. 



\section{AGRADECIMENTOS}

Agradeço, em primeiro lugar, a meus pais, Geni e João, pelo amor incondicional, pela dedicação e força, pelo cuidado e investimento, de todas as formas possíveis, sem os quais eu não teria conseguido, e por existirem para mim da forma como existem.

A minha orientadora, Profa. Dra. Cibele Haddad Taralli, pelo acolhimento, por acreditar na relevância do tema pertinente a este trabalho, pelo apoio, direcionamento e suporte, e por todo conhecimento que me transmitiu durante estes anos de mestrado. Foi um privilégio tê-la como orientadora nesta jornada.

A minha amada irmã e amiga, Mariana, pela qual tenho imensa admiração por sua força e inteligência e por quem sinto saudades diariamente, agradeço a compreensão por minha ausência.

A Fau-Usp, pela oportunidade de colocar em prática o desejo de investigar o tema proposto nesta pesquisa e por todo conhecimento que adquiri durante o mestrado nesta instituição; aos funcionários da FAU Maranhão por toda ajuda sempre que precisei.

A Profa. Dra. Denise Dantas, pela oportunidade de ter sido sua monitora no PAE, além de todo o aprendizado acumulado na disciplina Design Centrado no Usuário e, sobretudo, por ter aberto portas que tornaram possível parte fundamental deste trabalho.

Aos professores da USP, de todos os departamentos, que me deram o privilégio de cursar suas disciplinas durante o mestrado e me enriqueceram intelectualmente com o aprendizado transmitido.

A todas as funcionárias e funcionários das instituições que visitei e que, de alguma forma, tornaram esta dissertação possível, em especial a Tauany, Beth, Cleuda, Silmara e Isaura, Eulália, Fátima, Deise, Antônio, Azilde, Ângela, Fernanda e Lucas Colebrusco, que foram muito gentis e prestativos para com minhas necessidades em relação a este trabalho. Além disso, gostaria de agradecer à diretoria do Colégio X, que permitiu meu acesso às bibliotecas da escola, tornando este trabalho possível. Em especial, gostaria de agradecer a todos os alunos, pais e professoras do Colégio X que participaram da experiência do storytelling, ferramenta essencial para este trabalho. 
A Nina Neves, amiga iluminada e amorosa, companheira de rotina e de moradia, que me deu forças e suporte durante toda esta jornada, agradeço pela amizade, pelo amor, pelos cuidados, pelas risadas e, sobretudo, por acreditar na minha capacidade quando eu me esquecia.

A Raul Lorenzeti, por existir, pelos cuidados e quereres, pela torcida e, sobretudo, por me lembrar que é possível.

A Julia Asche pela amizade, por se preocupar comigo, por tomar conta de mim, pelas refeições partilhadas e por me apresentar ao Design Possível, me acolhendo também em sua vida profissional.

A Lilith Neiman, com quem tenho o prazer de morar e tive a sorte de descobrir amiga durante esta jornada, que me ajudou nesta reta final, com cuidados e conselhos, meus sinceros agradecimentos.

A Aline Lemos e Thales Molina, por acreditarem em mim, pelo carinho e pela vida dividida em São Paulo. Obrigada também pela ajuda que me deram neste trabalho. Ao amigo Victor Próspero, por participar de meu cotidiano, tornando minha rotina leve e divertida.

A Elisa Feltran, pela amizade e carinho, por se preocupar comigo, por estar presente e pela compreensão em relação ao meu momento. Neste sentido, agradeço também a Erica Ribeiro pelo conhecimento partilhado e pela compreensão.

A meu avô Inácio, a minhas tias e tios, primas e primos, que compreendem minha ausência e que torceram pelo meu sucesso e pela existência deste trabalho, meus agradecimentos e meu amor.

Aos amigos e colegas que participaram, de perto ou de longe, da minha vida nestes anos de mestrado, tornando tudo mais leve e prazeroso, em especial a Thais, Irina, Bia, Rafa, Felipe, Julia Goyata, Luiza Ramos, Maíra, Jozie, Flávio, Catarina, Letícia, Camila, Evelyne, Mariana, Carol, Luli, Ricardo, Betina, Teo, Martha, Rapha, Fina, Laura, Gui, Marcos, Renato, Lucas, João Paulo e todos os que não estão diretamente citados aqui, mas que me fizeram sentir capaz de passar por este processo até a finalização do mestrado, meus sinceros agradecimentos. 
"É do cultivo dado à infância, da sua direção nos primeiros anos, que advirá a formação do caráter e da mentalidade da geração que nos há de suceder."

- Antônio Caetano de Campos 



\section{RESUMO}

As bibliotecas são espaços dinâmicos, centros de aprendizagem e de lazer que necessitam estar em consonância com o público ao qual atendem. Por sua importância relacionada ao desenvolvimento cognitivo, à emancipação em termos de aprendizagem e à cultura e socialização imbricadas a sua essência, as bibliotecas voltadas para o público infantil são o tema da presente pesquisa.

Reconhecendo-se que o bom uso da biblioteca está intrinsecamente conectado a aspectos relativos à organização espacial do local e a seus equipamentos, esta pesquisa teve como objetivo compreender como se dá a relação da criança em bibliotecas voltadas para este público, com seu ambiente e com os equipamentos ali presentes, visando extrair da análise destas experiências aspectos que possam servir para projetos futuros relacionados ao tema.

Para tanto, foi feita uma pesquisa bibliográfica que buscou compreender como se deu a criação da infância enquanto aspecto cultural e a relevância da criação da Biblioteca Infantil Municipal, atualmente denominada Biblioteca Infantojuvenil Monteiro Lobato, para a cidade de São Paulo na década de 1930.

Além disso, discutiu-se a Infoeducação e os aspectos a ela imbricados, que norteiam as análises dos ambientes aqui estudados. Uma compilação dos mobiliários atualmente ofertados pela indústria brasileira pra escolas e bibliotecas e a análise de bibliotecas com espaços infantis que apresentam projetos inovadores para a área também constituem esta pesquisa.

Por fim, foram realizados dois estudos de caso de bibliotecas voltadas para o público infantil (uma pública e a outra escolar), coletando dados referentes à atuação de crianças entre seis e nove anos nas mesmas, com a adição da coleta de dados com outros personagens que fazem parte, direta ou indiretamente, da experiência das crianças nestes locais como, por exemplo, os pais e/ou responsáveis, as bibliotecárias e as contadoras de histórias.

A análise dos dados coletados e os resultados obtidos com os estudos de caso foram confrontados por meio de uma triangulação dos dados gerados com os aspectos relacionados à Infoeducação e à ofertada da indústria brasileira para os ambientes em questão, permitindo, assim, tecer considerações acerca dos re- 
sultados obtidos com esta experiência.

Palavras-chave: design, ambiente construído, biblioteca infantil, biblioteca escolar, mobiliário infantil, Biblioteca Infantojuvenil Monteiro Lobato 


\section{ABSTRACT}

Libraries are dynamic spaces, centers of learning and recreation that need to be in consonance with the public they serve. Because of its importance in relation to cognitive development, emancipation, in terms of learning, culture and socialization imbricated to its essence, children's libraries are the subject of this research.

Recognizing that the good use of the library is intrinsically connected with aspects related to the spatial organization and to the equipments that belong to these libraries, this research has as its main objective, to understand how kids interact with these libraries and its equipments, aiming to extract from the analysis of these experiences, aspects that may be useful for future projects related to this area of study.

To make it possible, a bibliographical research was realized in aiming to understand the creation of the childhood's concept, as a cultural aspect and also about the relevance of the creation of the Municipal Children's Library (nowadays called Biblioteca Infantojuvenil Monteiro Lobato) to the city of São Paulo in the 1930s.

In addition, aspects concerning the essence of the Infoeducation were discussed, which guided the analysis of the spaces studied here. A compilation of the furniture provided by the Brazilian industry for schools and libraries and an analysis of libraries with children's spaces that have innovative projects for the areas of design and architecture are also part of this research.

Finally, there are two cases of children's libraries (a public children library and a school library), collecting data related to the performance of children between six and nine years old, with an addition of data collected with other characters that are directly or indirectly part of the experience of the kids at these places, such as parents and / or guardians, librarians and storytellers.

The analysis of the data collected and the results obtained with the cases were confronted using a triangulation of the data generated with the aspects related to the Infoeducation and the furniture offered by the Brazilian industry in general, making it possible to generate considerations about the results obtained with this experience.

Keywords: design, built environment, children's library, school library, children's furniture, Biblioteca Infantojuvenil Monteiro Lobato 
SUMÁRIO

INTRODUÇÃO - 19

APRESENTAÇÃO -19

QUESTÃO FUNDAMENTAL -22

OBJETIVO GERAL —- 22

OBJETIVOS ESPECÍFICOS - 23

APRESENTAÇÃO DA ESTRUTURA DA DISSERTAÇÃO —-23

CAPÍTULO 1 - INFÂNCIA: CONSTRUÇÃO SOCIAL —-25

1.1 INFÂNCIAL CONSTRUÇÃO SOCIAL -26

1.2 ANTES DA PRENSA TIPOGRÁFICA - A INFÂNCIA

NA IDADE MÉDIA $\longrightarrow 28$

1.3 INFÂNCIAS MODERNA E CONTEMPORÂNEA — 33

1.4 ANOS 1930: MODERNISMO, SÃO PAULO E A

BIBLIOTECA INFANTIL DE SÃO PAULO -35

1.5 O DEPARTAMENTO DE CULTURA DE SÃO PAULO - 37

1.6 A BIBLIOTECA INFANTIL DE SÃO PAULO — 41

CAPÍTULO 2 - BIBLIOTECA $\longrightarrow 47$

2.1 BIBLIOTECA: RELEVÂNCIA SOCIAL E TIPOS 48

2.2 BIBLIOTECA PÚBLICA INFANTIL E ESCOLAR:

ESPECIFICIDADES E SIMILARIDADES -50

2.3 A INFORMAÇÃO NA CONTEMPORANEIDADE:

SOCIEDADE DA INFORMAÇÃO -52

2.4 INFOEDUCAÇÃO: PROTAGONISMO JUVENIL E

APROPRIAÇÃO DA INFORMAÇÃO -55

2.5 BIBLIOTECA: DISPOSITIVO CULTURAL $\quad 56$

CAPÍTULO 3 - ESTADO DA ARTE -59

3.1 APRESENTAÇÃO 60

3.2 MOBILIÁRIO INFANTIL PARA ESCOLAR E BIBLIOTECAS 60 
3.2.1 CRITÉRIOS PARA AVALIAÇÃO DO MOBILIÁRIO

3.2.2 AS EMPRESAS SELECIONADAS

3.2.3 ANÁLISE ACERCA DAS DIMENSÕES DOS PRODUTOS

3.2.4 MATERIAIS E CORES OFERTADOS PELO

MERCADO

3.3 ANÁLISE DE BIBLIOTECAS INFANTIS

3.3.1 CRITÉRIOS 76

3.3.2 ANÁLISE DOS AMBIENTES

CAPÍTULO 4 - ESTUDOS DE CASO

4.1 OS OBJETOS DOS ESTUDOS DE CASO 91

4.2 STAKEHOLDER MAP 92

4.3 MÉTODOS E FERRAMENTAS 93

4.3.1 STORYTELLING

4.3.2 OBSERVAÇÃO NÃO PARTICIPANTE

4.3.3 ENTREVISTAS SEMI-ESTRUTURADAS 96

4.3.4 QUESTIONÁRIO IMPRESSO 97

4.4 ESTUDO DE CASO 1- BIBLIOTECA

INFANTOJUVENIL MONTEIRO LOBATO

4.4.1 SOBRE A BIBLIOTECA 98

4.4.2 SALA DO ACERVO INFANTIL E DA 98

PRIMEIRA INFÂNCIA

4.4.3 STAKEHOLDER MAP

4.4.4 MÉTODOS E FERRAMENTAS $-106$

4.4.5 RESULTADOS OBTIDOS 107

4.5 ESTUDO DE CASO 2 - COLÉGIO X 110

4.5.1 SOBRE A ESCOLA 133

4.5.2 STAKEHOLDERS MAP

4.5.3 MÉTODOS E FERRAMENTAS

4.5.4 BIBLIOTECA ALFA

4.5.5 BIBLIOTECA BETA 
CAPÍTULO 5 - CONCLUSÕES E CONSIDERAÇÕES $-189$

5.1 O ESPAÇO, SUA ORGANIZAÇÃO E OS

EQUIPAMENTOS QUE O COMPÕEM

5.2 A BIBLIOTECA E SEU USUÁRIO 194

5.3 O PAPEL DA BIBLIOTECA: EDUCAÇÃO E CULTURA —196

REFERÊNCIAS BIBLIOGRÁFICAS 200 


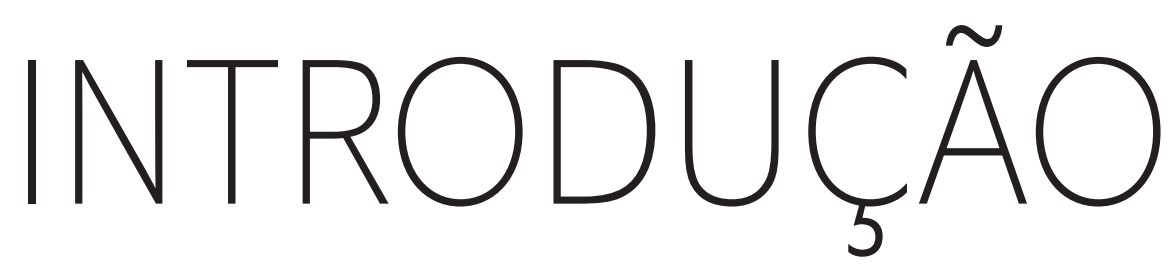





\section{APRESENTAÇÃO}

A biblioteca, independentemente de sua classificação, é um local que possibilita a prática da cidadania, a busca e a expansão do conhecimento, o lazer, o descanso e o acesso à informação em suas mais variadas formas. No que diz respeito às bibliotecas voltadas para o público infantil, são ambientes repletos de possibilidades literárias, com a função de socializar a criança, construir conhecimento, qualificar o ensino. As bibliotecas infantis são espaços sociais que contribuem para a formação da criança enquanto indivíduo e, para além disso, enquanto cidadã inserida em uma sociedade dinâmica e complexa.

Para o campo do Design, voltar-se para os ambientes que compõem as bibliotecas infantis é dever que exige não apenas conhecimento técnico, mas também sensibilidade para compreender as necessidades deste público tão particular. Além disso, considerando-se a essência social de ambas as áreas do conhecimento, é imprescindível que contribuam para soluções de projeto adequadas a estes ambientes.

Quando se fala em bibliotecas voltadas para o público infantil, abre-se espaço para pensar em bebês, crianças e pré-adolescentes. No caso específico desta pesquisa, optou-se por restringir seu escopo em relação à idade das crianças para entre seis e nove anos. Tal restrição deu-se, primeiramente, pela necessidade de fixar-se em um grupo específico de usuários e, segundamente, por acreditarse que este segmento etário é interessante, no sentido que, em alguns aspectos, se encontram em uma realidade de desenvolvimento muito próximos; porém, no que diz respeito ao desenvolvimento cognitivo pertinente à leitura e à escrita, crianças de seis anos estão iniciando seu processo de letramento, encontrando-se muito distantes das crianças de nove anos, que já possuem bastante intimidade com a leitura e com a escrita. Neste sentido, foi possível abarcar em um único estudo grupos em idade escolar com semelhanças e diferenças que os unem em algumas necessidades ou os fazem necessitar de soluções diferentes para seus anseios.

No que diz respeito à intenção investigativa desta pesquisa, buscou-se compreender, apoiando-se no uso de métodos e ferramentas pertinentes, como 
se dá a dinâmica das crianças nos espaços a elas destinados, em bibliotecas de caráter infantil, no caso de bibliotecas públicas e de bibliotecas escolares.

Em seus primeiros momentos, esta pesquisa tinha como objetivo depreender como se dá a relação da criança com equipamentos de leitura digital, como por exemplo tablets, em bibliotecas infantis de caráter público. Após primeiras investigações acerca do tema, compreendeu-se que não seria possível dar continuidade à pesquisa, devido à inexistência destes aparelhos em bibliotecas públicas infantis no Brasil. Buscou-se, então, analisar os ambientes de bibliotecas públicas infantis na cidade de São Paulo e como se dava a experiência das crianças nestes locais. Observou-se que, para enriquecer as possibilidades relacionadas aos ambientes e às atividades neles oferecidos, seria necessário abarcar, neste trabalho, bibliotecas escolares, pois há um investimento maior nas bibliotecas destas instituições, principalmente das bibliotecas de escolas particulares.

Desta forma, para atingir seus objetivos, foram feitas pesquisas de cunho bibliográfico que retratam o percurso da infância enquanto construção social, cujo significado para este trabalho se encontra na necessidade de reforçar a importância de investir em ambientes de cunho sócio-educativo, como é o caso da biblioteca. Além disso, foram feitas investigações acerca do estado da arte de mobiliários pertinentes a bibliotecas e escolas na indústria brasileira, bem como uma análise de bibliotecas com espaços infantis, que se tornam interessantes para esta pesquisa devido ao reconhecimento em premiações mundialmente recebidas. Além disso, foram realizados dois estudos de caso, um na Biblioteca Infantojuvenil Monteiro Lobato e o outro em duas bibliotecas escolares, em um colégio denominado "Colégio X"1 nesta pesquisa.

Esta pesquisa amparou-se em aspectos intrínsecos à Infoeducação para validar questões como apropriação do espaço e de seus elementos por parte do usuário e do protagonismo infantil nas instituições analisadas, que serão discutidos no Capítulo 2 desta dissertação.

Para atingir seus objetivos, este trabalho levou em consideração parâmetros comumente tratados em resoluções de projetos nas áreas do Design e da Ar-

1 Esta denominação tem como intuito preservar a escola e a segurança de seus alunos e funcionários, além de fazer parte das exigências da ética na pesquisa com crianças. 
quitetura, tais como os relativos à ergonomia e a antropometria, por exemplo; mas teve também o cuidado de se voltar para aspectos de ordens subjetiva e emocional, relativos à percepção do próprio usuário em relação aos espaços estudados. Não obstante, é válido mencionar que foram analisados diversos indivíduos que fazem parte da experiência da criança na biblioteca, a depender da classificação da mesma, com o intuito de aprofundar esta investigação e de trazer dados que foram fundamentais para compreender as razões que levam às dinâmicas estabelecidas nas bibliotecas analisadas.

É sabido que a biblioteca, no que diz respeito aos objetos que a compõem e à sua organização espacial, pode ser analisada em relação a diversos aspectos, levando-se em consideração desde a sinalização do ambiente até aspectos relativos à acústica e à temperatura do local. Para esta pesquisa, os principais aspectos analisados para compreender como se dá a relação da criança com estes espaços foram relativos aos mobiliários e equipamentos que as compõem, buscando depreender se estes estão adequados à realização das atividades propostas para os usuários. Aspectos relativos à estética e à ludicidade também foram levados em consideração na análise dos locais.

Considerando-se tratar de uma pesquisa de natureza qualitativa, esta busca, portanto, analisar as qualidades pertinentes aos estudos de caso que foram objetos deste estudo, não significando que os resultados aqui obtidos sejam tomados como verdade universal para ambientes de mesma espécie, mas que levam, nos resultados obtidos com a análise dos dados em questão, a apontamentos que podem sim servir como sugestões projetuais para ambientes semelhantes.

A pesquisadora gostaria de ressaltar que, dentre as dificuldades encontradas no percurso da realização desta dissertação, o mais problemático para a existência deste trabalho foi a dificuldade em se tratar de um estudo que necessita de acesso a crianças, sobretudo em ambientes escolares. A impossibilidade de filmá -las ou fotografá-las em ambientes públicos ou privados e de todas as cláusulas que envolvem o uso da imagem do menor, considerando-se que foi possível fazer uso das ferramentas mencionadas, dificultou a rapidez no desenvolvimento do cronograma da pesquisa. Torce-se para que, no futuro, mais instituiç̧̃̃es de ensino abram suas portas para que a pesquisa acadêmica possa se valer das mesmas, 
considerando-se que é de extrema importância a aplicabilidade dos conhecimentos gerados em ambientes acadêmicos na sociedade e a colaboração de ambas as partes para que isto aconteça.

Espera-se, portanto, com esta pesquisa, colaborar com o campo do Design, da Arquitetura, da Ciência da Informação, da Biblioteconomia e da Educação, no sentido de que estas áreas estão intimamente relacionadas a uma boa experiência da criança na biblioteca infantil. Busca-se, aqui, levantar aspectos relevantes para tornar o ambiente da biblioteca acolhedor para que as crianças o vejam como um local destinados a elas e que, desta forma, se apropriem das bibliotecas em todas as possibilidades que esta tem a oferecer.

\section{QUESTÃO NORTEADORA DA PESQUISA}

Como se relacionam, crianças entre seis e nove anos, com as instalações e os sistemas informacionais em bibliotecas de caráter sócio-educativo voltadas para este público, na cidade de São Paulo, observando-se as implicações no arranjo espacial e em seus componentes, tais como mobiliários e equipamentos, tendo em vista a interação da criança com a informação e com o acervo disponíveis em todas as possibilidades que esta tem a oferecer?

\section{OBJETIVOS}

\section{OBJETIVO GERAL}

Investigar como se dá a relação da criança com o ambiente da biblioteca infantil, seu mobiliário, equipamentos e acervo, tendo em vista a apropriação da informação e do conhecimento pela criança, bem como sua autonomia nos espaços estudados, utilizando-se de ferramentas de pesquisa específicas que ajudem a indicar os usos e as práticas nos espaços. 


\section{OBJETIVOS ESPECÍFICOS}

- Compreender se os estudos de caso se revelam local de apropriação do espaço e da informação com protagonismo por parte do usuário, aspectos inerentes às práticas da Infoeducação;

- Investigar se as crianças observadas nos estudos de caso conseguem realizar as atividades propostas, considerando-se o peso da organização do espaço e de seus componentes nesta relação;

- Catalogar mobiliários pertinentes a espaços escolares e bibliotecas infantis, buscando compreender a oferta da indústria brasileira em relação a esses objetos, e se estas possibilidades de produtos justificam os equipamentos encontrados nos estudos de caso em questão;

- Analisar fotografias de bibliotecas que são consideradas, por diversas razões, referência de projeto em design e arquitetura, observando quais são os aspectos que as tornam locais bem qualificados, neste sentido.

\section{ESTRUTURA DA DISSERTAÇÃO}

Esta dissertação foi dividida na presente Introdução da Pesquisa, cujo objetivo é o de contextualizar este estudo nos aspectos básicos necessários para a compreensão prévia do que será estudado, juntamente com cinco capítulos, que serão apresentados a seguir:

Capítulo 1: Constitui-se de um panorama histórico, cujo objetivo é de explicar como se chegou à infância como conhecemos na contemporaneidade, debruçando-se sobre a relação da infância com o acesso à informação, buscando também fazer um paralelo entre a construção social da infância e a história da função da biblioteca. Parte deste capítulo é dedicado à Biblioteca Municipal Infantil da cidade de São Paulo, entre as décadas de 1930 e 1960, pela importância histórica e simbólica desta biblioteca para a cidade e que depois viria se chamar Biblioteca Infantojuvenil Monteiro Lobato, um dos objetos de estudo desta pesquisa.

Capítulo 2: Aqui são apresentadas as características que compõem as bibliotecas infantis e as bibliotecas escolares, bem como a relevância deste tipo de 
espaço para a sociedade e para a formação da criança. Além disso, são apresentados conceitos como Infoeducação, dispositivos educacionais e protagonismo infantil, que norteiam a análise dos estudos de caso da pesquisa.

Capítulo 3: Este capítulo traz uma compilação de mobiliários atualmente disponíveis para escolas e bibliotecas infantis pela indústria moveleira brasileira. Serão apresentados produtos considerados inovadores para a área e também aqueles mais comumente encontrados em bibliotecas públicas os escolares.

Capítulo 4: Neste capítulo são apresentados os estudos de caso da pesquisa, os métodos utilizados em cada um deles, a análise destes ambientes e os resultados obtidos com estas análises.

Capítulo 5: Dedica-se a discutir os resultados obtidos na análise dos estudos de caso, trazendo também as considerações finais sobre a pesquisa. 


$$
\begin{aligned}
& \text { CAPÍTULO } 1 \\
& \text { INFÂNCIA: } \\
& \text { CONSTRUÇÃO } \\
& \text { SOCIAL }
\end{aligned}
$$





\subsection{INFÂNCIA: CONSTRUÇÃO SOCIAL}

A história da infância ocidental está fortemente entrelaçada à história da informação e da leitura. Ao contrário do que se infere quando se pensa em infância, ela não é um fator biológico, mas sim uma construção social que precisou de mais de dois séculos para ser maturada e aproximar-se da noção de criança que temos hoje: um ser em desenvolvimento com características e necessidades próprias.

Até a Idade Média, a criança era uma espécie de "adulto em miniatura", que convivia e participava de todas as atividades sociais em conjunto com os adultos sem que houvesse qualquer pudor ou cuidado em privá-las de quaisquer acontecimentos e experiências do cotidiano. Não havia, portanto, o sentimento de infância pois, por diversos motivos posteriormente citados neste capítulo, não havia a concepção de adulto.

Com a criação da prensa tipográfica por Gutenberg, em meados de 1450, e a possibilidade de se compilar e distribuir informação, foi necessário criar uma fronteira entre aqueles que poderiam ter acesso aos conteúdos dos documentos impressos e aqueles que ainda não tinham maturidade para tal. Surge, assim, a criação do sentimento de infância e, com ele, a necessidade de se ampliar a quantidade de escolas, para formar futuros adultos capazes de ler e com maturidade para lidar com a vida adulta.

Durante a Idade Moderna, houve a gestação deste sentimento de infância, 
que desembocou no que conhecemos como "criança" na contemporaneidade. Foi neste período, também, que a biblioteca foi repensada enquanto espaço físico pois a vida pós-prensa tipográfica estava repleta de milhares de novos títulos, o tamanho dos acervos das bibliotecas crescera exponencialmente e, por isso, foi necessário repensar a forma como se organizava o acervo.

Este capítulo terá, além do aprofundamento destas etapas que culminam na criança contemporânea, um momento dedicado ao estudo do surgimento da Biblioteca Infantil de São Paulo, que ocorreu na cidade na década de 1930. Acredita-se que a criação de uma biblioteca pública voltada para crianças no início do século XX foi fator de grande importância, tanto para colaborar com a construção da afirmação de São Paulo enquanto centro cultural do país, quanto para compreender o espaço que a criança ocupava na sociedade modernista e como isto estava refletido num ambiente de caráter inédito, voltado para este público. Atualmente, esta biblioteca se chama Biblioteca Infantojuvenil Monteiro Lobato, e consta como objeto de estudo desta pesquisa, localizado no Capítulo 4 da mesma.

\subsection{ANTES DA PRENSA TIPOGRÁFICA - A INFÂNCIA NA IDADE MÉDIA}

A contemporaneidade enxerga a criança como um ser diferente do adulto, que necessita de cuidados e de tratamento especial para que atinja seu máximo potencial a partir dos cuidados da família e da escola. Esta visão está tão enraizada na sociedade contemporânea que alguns tomam a infância como um fator biológico. Nossa concepção de infância é, no entanto, fruto de uma construção social que atinge seu clímax no decorrer da Idade Moderna, época em que diversas transformações sociais, incluindo aqui o fator "sociedade letrada", possibilitaram mudanças drásticas que levaram, após aproximadamente duzentos anos, a sociedade a enxergar a criança como o faz a sociedade contemporânea.

A infância como o ocidente conhece há pelo menos três séculos só existe porque, em meados do século XVI, passou a haver um novo adulto. A tipografia criou um novo mundo simbólico

[...] que exigiu, por sua vez, uma nova concepção de idade adulta. A nova 
idade adulta, por definição, excluiu as crianças. E como as crianças foram expulsas do mundo adulto, tornou-se necessário encontrar um outro mundo que elas pudessem habitar. Este outro mundo veio a ser conhecido como infância. (POSTMAN, 1999, p.34)

O autor afirma ainda que a infância na Idade Média encerrava-se em torno dos sete anos de idade, quando a criança já dominava as palavras e podia, então, participar do mesmo universo que os adultos.

Sobre o tema, Maisons-Laffitte no prefácio para Àries (1973), afirma que "A duração da infância era reduzida a seu período mais frágil, enquanto o filhote do homem não conseguia abastar-se; a criança, então, mal adquiria algum desembaraço físico, era logo misturada aos adultos, e partilhava de seus trabalhos e jogos." É possível ratificar a conexão entre a idéia de infância com a de dependência, observando-se o emprego do uso de palavras como fils, valets e garçons, pois estas eram utilizadas tanto para falar sobre crianças (estágio da vida em que se depende totalmente de adultos para sobreviver), quanto para as relações feudais que implicam dependência dos vassalos para com seus senhores. (ARIÈS, 1981, p.11)

Postman (1999, p.25) destaca "quatro grandes razões que justificam uma civilização viver considerável período temporal sem se ater ao conceito de desenvolvimento infantil: a não-alfabetização, a educação, o conceito de vergonha e a massiva mortalidade infantil.”

No que concerne o desaparecimento da alfabetização, justifica-se principalmente porque, durante a Idade Média, os europeus esquecem da importância da legibilidade dos caractéres para o reconhecimento rápido e automático das palavras, quando passam a adotar estilos rebuscados e dissimulados de grafia. Desta forma, houve, nesta época, quase que a extinção da alfabetização social, significando a perda, para a maioria das pessoas, da ideia essencial da alfabetização. Outro fator que pode ter agravado a situação da falta de alfabetização socializada, foi a escassez das fontes de fornecimento de papiro e pergaminho e, além disso, a falta de condições do povo em investir neste tipo de dispêndio. "O que aconteceu na 
Europa - para dizê-lo com simplicidade - não foi o desaparecimento do alfabeto; foi sim, o desaparecimento da capacidade do leitor para interpretar o que se escrevia." (POSTMAN, 1999, p.26)

Com o desaparecimento de quase mil anos da alfabetização social, a população medieval majoritariamente não sabia ler, significando que todas as interações sociais se realizavam oralmente, face a face, como aconteceu no curso de quase toda a história dos seres humanos. A capacidade de ler e escrever destrói a sociologia da oralidade, num sentido que

\begin{abstract}
(a leitura) torna possível entrar num mundo de conhecimento não observável e abstrato, a leitura cria uma separação entre os que podem e os que não podem ler. A leitura é o flagelo da infância porque, em certo sentido, cria a idade adulta. Assim, num mundo letrado, ser adulto implica ter acesso a segredos culturais codificados em símbolos não naturais. Num mundo letrado, as crianças precisam transformar-se em adultos. Entretanto, num mundo não letrado não há necessidade de distinguir com exatidão a criança e o adulto, pois existem poucos segredos e a cultura não precisa ministrar instrução sobre como entendê-la. (POSTMAN, 1999, p. 27-28)
\end{abstract}

A ausência de uma sociedade letrada justifica a ausência de escolas primárias. As poucas escolas que existiam estavam associadas à Igreja ou eram particulares e seu modo de aprender era por meio da oralidade, com a prática de algum serviço. Elas se caracterizavam pela "falta de gradação nos currículos de acordo com a dificuldade no assunto, pela simultaneidade no ensino das matérias, pela mistura das idades e pela liberdade dos alunos." (ARIÈS apud POSTMAN, 1999, p.28)

Da mesma maneira, o conceito de biblioteca na época remetia apenas ao de depósito de informações. $\mathrm{O}$ acesso a estes ambientes era restrito ao monastério e aos poucos que tinham permissão para acessá-los. Milanesi (2002, p.23) afirma que "ler e escrever eram habilidades quase exclusivas dos religiosos e não se destinavam a leigos."

No que tange o conceito de vergonha, Postman (1999, p.29) afirma que 
na Idade Média, sem uma cultura na qual existisse uma diferença mar cante entre o adulto e a criança, não havia, portanto, a necessidade de prever momentos ideais para revelar a uma criança certas facetas da vida que a sociedade dela esconde, por acreditar que esta ainda não tem maturidade emocional para saber. "Imersa num mundo oral, vi vendo na mesma esfera social dos adultos, desembaraçadas de instituições segregadoras, a criança na Idade Média tinha acesso a quase todas as formas de comportamento comuns à cultura.

Soma-se aos três fatores mencionados como razões pelas quais o conceito de infância não existiu no mundo medieval, a alta taxa de mortalidade infantil, assim os adultos não tinham, e não podiam ter, com elas o envolvimento emocional que aceitamos como normal.

Sempre que surge uma nova tecnologia de comunicação, pode-se observar mudanças de ordem social e cultural nas sociedades. A prensa tipográfica permitiu uma explosão de conhecimento, a reordenação do pensamento dos leitores e, mais especificamente, criou o homem letrado.

Com o surgimento da prensa tipográfica e as possibilidades que trouxe, como barateamento de obras antes inacessíveis à massa, o aumento da quantidade de obras de todos os gêneros e ciências e até mesmo a facilitação em traduzir obras em idiomas estrangeiros, houve a necessidade de dar novo significado o adulto medieval.

Com a ampliação da diversidade e do volume de acervo que existiu após a criação da prensa de tipos móveis, a biblioteca precisou ser repensada enquanto espaço físico. Milanesi (2002, p.27) afirma que com a mudança do caráter religioso e sagrado que os livros tinham para o de instrumento de conhecimento segmentado, "as pequenas salas com livros acorrentados e com ar de capela não eram mais suficientes".

A invenção da tipografia foi uma das maiores revoluções da história da humanidade. Sua chegada trouxe diversos avanços na velocidade de produção, armazenamento e distribuição de informação. Meggs e Purvis (2009, p.91) afirmam que "o conhecimento se disseminou rapidamente e a alfabetização aumentou em 
decorrência dessa notável invenção. A demanda por livros se tornou insaciável."

Baseando-se na afirmação de Bruner (1997, p.23) de que "nós vivemos publicamente através de significados públicos, compartilhados por procedimentos públicos de interpretação e negociação", reforça-se que em uma sociedade baseada em oralidade, como é o caso da Idade Média, a informação e o conhecimento ficam restritos àqueles que detêm o acesso aos livros e à forma de decodificar as informações destes suportes: a leitura.

Assim, se até então o acesso aos livros estava restrito à Igreja e ao Estado, o barateamento e a difusão do livro quebraram o monopólio do conhecimento que poucos na sociedade detinham. Além disso, deve-se registrar o papel das transações comerciais no crescimento da produção e disseminação dos livros. Iniciava-seaqui, a criação de uma nova indústria baseada no registro do conhecimento: "o livro deixava de ser uma obra reverenciada pelo seu valor material e simbólico e transformava-se em um produto qualquer dentro do mercado". (MILANESI, 2002, p.28)

A quantidade de conhecimento gerado e disponível durante os cinquenta primeiros anos que seguiram a criação da tipografia criaram um novo ambiente simbólico que encheu o mundo de novas informações e de experiências abstratas. Em um mundo onde a oralidade já não era mais a forma utilizada para se comunicar e viver, quando se tornou absolutamente necessário saber decodificar os caracteres para sobreviver nesta nova sociedade, um novo homem adulto precisou ser criado e também se adaptar. Com a invenção deste idade adulta, automaticamente foi preciso encontrar espaço para as crianças.

\footnotetext{
A partir daí a idade adulta tinha de ser conquistada. Tornou-se uma realização simbólica e não biológica. Depois da prensa tipográfica, os jovens teriam de se tornar adultos e, para isso, teriam de aprender a ler, entrar no mundo da tipografia. E para realizar isso precisariam de educação. Portanto a civilização européia reinventou as escolas. E, ao fazêlo, transformou a infância numa necessidade. (POSTMAN, 1999, p.50)
}

Durante a Idade Moderna, esta nova noção de ser adulto e, consequentemente, de ser criança começa a amadurecer. Os papéis da família e das instituições também se alteram, colaborando para o enraizamento da noção de criança que o ocidente conhece. 


\subsection{INFÂNCIAS MODERNA E CONTEMPORÂNEA}

A modernidade foi marcada, em relação à infância e à educação, por ter sido a época ocidental na qual a criança passou a ser vista como uma criatura especial, que demandava necessidades específicas e que precisava estar separada do mundo adulto. Desta forma, as instituições educacionais passaram a se tornar o espaço que supria esta necessidade de se separar a criança do espaço que concerne ao adulto, e também de ensiná-la a ler e a escrever, tipo de criança que a nova sociedade letrada exigia. Este amadurecimento do que hoje vemos como normal no tratamento em relação à infância precisou de aproximadamente dois séculos para se consolidar, os XVI e XVII.

É válido ressaltar a fala de Postmann (1999, p.53) que afirma que a infância evoluiu desigualmente, porque após a filtragem das complexidades históricas, surge uma equação bastante simples: onde a instrução foi sempre altamente valorizada, havia escolas, e, onde havia escolas, o conceito de infância desenvolveu-se rapidamente. O autor afirma ainda que, neste momento em questão, "os processos de uma educação letrada deviam evoluir com o desenvolvimento da criança; a leitura devia começar aos 4 ou 5 anos, seguindo-se a escrita, e depois, gradualmente, deviam ser acrescentados assuntos mais sofisticados. A educação [ficou] quase inflexivelmente ligada à idade cronológica das crianças."

Interessante notar que este tipo de hierarquia dos aprendizados e da organização dos grupos escolares descritos para os séculos XVI e XVII se assemelham em demasia ao que é ofertado atualmente na maioria das escolas, comprovando que, de fato, a Idade Moderna foi o berço da forma como se enxerga a infância contemporaneamente.

Postman (1999, p.59) se baseia na fala de Du Boulay para discorrer acerca da associação deste fenômeno da infância com parâmetros relacionados à economia e aos poderes aquisitivos das famílias. O autor afirma que

"uma melhora na condição econômica propiciou a intensificação da consciência no que toca às crianças e as tornou mais visíveis socialmente. Assim como é bom lembrar que os meninos foram, de fato, a pri- 
meira categoria de pessoas especializadas, devemos também lembrar que eles eram os meninos da classe média. A infância começou indiscutivelmente como uma ideia de classe média, em parte porque a clas se média podia sustentá-la. Outro século se passaria antes que a ideia se infiltrasse nas classes mais baixas."

O pico da infância como a conhecemos ocorreu entre os anos 1850 e 1950, por ter sido o período no qual se moldou o esteriótipo da família moderna burguesa. De acordo com Prost (2009, p.15) foi também nesta época que os apartamentos ou casas burguesas começaram a se caracterizar por uma diferença entre as salas destinadas a receber visitas e os demais aposentos. "As salas de recepção estabelecem, portanto, um espaço de transição entre a vida privada propriamente dita e a existência pública”.

Neste sentido, há também a mudança nos papéis da família, e suas funções são remoldadas, inclusive no que diz respeito à educação da criança. Àries e Duby (2009, p.53) consideram que como a família agora tem suas funções exclusivamente voltadas à vida privada isto acarreta também uma nova natureza para as funções da mesma: deixando de ser uma instituição forte, sua privatização é uma desinstitucionalização.

Neste sentido, é válido apontar para o aumento da responsabilidade da escola na educação das crianças, em no seu mais amplo sentido, papel anteriormente desenvolvido pela família e pela comunidade na qual esta criança estivesse inserida.

Esta abordagem histórica acerca do percurso do olhar sobre a criança é de suma importância para se compreender a dimensão da importância do pensamento vanguardista do extinto Departamento de Cultura de São Paulo, com a criação da Biblioteca Infantil de São Paulo, na década de 1930 e do pioneirismo que esta ação trouxe para a cidade em termos de educação, cultura e lazer para as crianças.

É importante também enfatizar que, ao menos no Brasil, até a década de 1930, não havia bibliotecas públicas voltadas para o público infantil. Em realidade, foi a partir do final do século XVIII que o público passou a ter acesso direto às bibliotecas. 


\subsection{ANOS 1930: MODERNISMO, SÃO PAULO E A BIBLIOTECA INFANTIL DE SÃO PAULO}

Para compreender tanto a importância simbólica quanto a real, em termos de cultura e educação, acerca da criação da Biblioteca Infantil de São Paulo, faz-se necessário contextualizar a situação da cidade de São Paulo nos aspectos políticos, econômicos e sociais, que justificam também a importância do Departamento de Cultura da cidade, órgão responsável pela existência da mais antiga biblioteca pública infantil do país em funcionamento.

A primeira metade do século XX, no Brasil, é marcada por intensas mudanças de ordens política e econômica. A proclamação da república não serviu para a criação de um governo que pensaria uma gestão voltada para as necessidades do povo, mas sim para servir aos interesses da elite. De acordo com Domingues (2002) apud Szmrecsányi (2011, p.19), "a Modernidade brasileira tem sido classificada como conservadora. A rejeição do status de Colônia e o desejo de participar do rol das nações mais avançadas da civilização ocidental fazem parte do ideário professado por nossas elites há mais de século."

Os historiadores denominam de República Velha, ou Primeira República, o período entre a Proclamação da República no Brasil e a Revolução de 1930. Este primeiro momento republicano no país foi marcado por um governo conservador e de militares, interessados em se manter no poder.

Szmrecsányi (2011, p.27) afirma que o início da república no país deu espaço para o firmamento da economia capitalista, em termos de mercado interno. Nossa modernização econômica se concretizou com o industrialismo nacional de base, especialmente na cidade de São Paulo, em detrimento da agroexportação como modelo econômico.

Para Abaurre \& Pontara (2011), a República trouxe também um processo de "europeização" do país, pois cidades como São Paulo e Rio de Janeiro (grandes centros políticos do Brasil), passaram por uma transformação do espaço urbano: com o objetivo de eliminar traços arquitetônicos de origem portuguesa, as cidades repensaram seus prédios e avenidas, procurando uma reurbanização que favorecesse, ainda que em aparência, o nascimento de cidades novas, modernas. 
Ainda sobre o tema,

\begin{abstract}
Pensando-se no modo de vida, na revolução dos costumes, com a elevação progressista do status doméstico e cívico da mulher, o umbral do século XX e, sobretudo, as duas décadas logo após 1914 se impõem comomomentos transformadores. De toda forma, sob critérios culturalistas, pode-se remontar a séculos bem anteriores, buscando a origem da Modernidade na revolta renascentista da razão contra o dogmatismo, com a constituição das ciências empíricas e o decisivo solapamento da cultura medieval para, dali por diante, o Ocidente renovar-se, intelectual e materialmente, em avanço contínuo.
\end{abstract}

(SZMRECSÁNYI, 2011, p.25)

A quebra da bolsa de Nova lorque em 1929, marco que colocou em risco a estabilidade econômica do ocidente, colaborou para uma crise que se desencadeou devido a fatores como a diminuição do consumo do café no mercado mundial, a super-safra de 1929 e a incapacidade do governo de comprar este excedente. (ABAURRE \& PONTARA, 2011, p.539)

No que tange a cidade de São Paulo, foi nestas primeiras décadas do século XX que a mesma iniciou sua trajetória na liderança econômica do país. De acordo com Abaurre \& Pontara (2011) a cidade do Rio de Janeiro era, desde a chegada da família real portuguesa ao Brasil em 1808, a cidade de maior prestígio político e social até então. O cultivo do café no interior do estado de São Paulo, que proporcionou o investimento financeiro da industrialização da capital, foi o principal fator de aceleração dos processos de urbanização e de industrialização da cidade de São Paulo.

É importante lembrar que, em meio a estas mudanças de ordens políticas e econômicas, o Modernismo foi o movimento cultural em voga na época. O movimento, que teve sua fase áurea na década de 1930, orquestrou o cenário artístico, social e intelectual da primeira metade do século XX.

Fez parte do espírito modernista de primeira hora a experimentação, o que levou muitos artistas a se manifestarem através de diferentes meios de expressão, libertando-se da cristalização das formas 
acadêmicas. Assim, as preocupações dessa vanguarda incluíram experiências nos vários setores da produção: literatura, dança, pintura, arqui tetura, música e até design. Vivendo tudo isso, Mário de Andrade (1893-1945) estudou com familiaridade e admirável clareza temas de todas as áreas de nossa cultura, revelando, a cada momento, uma de suas 'trezentas e cinquenta' faces, sempre apaixonadas pelas coisas das nossas artes e cultura. O mais expressivo representante do movimento moderno no Brasil talvez tenha concluído que não bastava enunciar os princípios desse movimento; era preciso pô-los em prática. (SANTOS, p.31, 2015)

A inauguração da Biblioteca Infantil de São Paulo (atualmente Biblioteca Municipal Infantojuvenil Monteiro Lobato), que aconteceu em 1936, estava atrelada, portanto, a uma São Paulo que começava a se consolidar como centro econômico e cultural do país, em meio a uma industrialização de base que necessitava, portanto, se reconfigurar para tentar alcançar outras cidades mundialmente importantes.

O Departamento de Cultura da cidade de São Paulo foi um dos grandes responsáveis, sob o comando de Mário de Andrade, por esta modernização da cidade, em termos de acesso da massa à cultura, até então privilégio da elite.

Portanto, faz-se necessário aprofundar-se no tema para esmiuçar a relevância da criação de uma biblioteca pública voltada para crianças, num país que ainda se iniciava enquanto república, em um contexto social tão discrepante, onde riqueza e miséria já coexistiam.

\subsection{O DEPARTAMENTO DE CULTURA DE SÃO PAULO}

A instalação das bibliotecas em SP remonta à década de 1930, quando houve, principalmente na cidade de São Paulo, o que Cândido (1985) denomina Rotinização do Modernismo, onde (se viu) "o alargamento das práticas literárias e artísticas, transformando aos poucos em padrão de uma época o que era considerado manifestação de pequenos grupos vanguardeiros".

O contexto cultural proporcionou mudanças, como esta transformação do 
que antes era visto como futurista, tanto na arte quanto na arquitetura, observouse também a preocupação destes pioneiros não só em rotinizar a cultura mas, de acordo com Cândido (1985), "a tentativa consciente de arrancá-la (a cultura) dos grupos privilegiados para transformá-la em fator de humanização da maioria, através de instituições planejadas." É nesta atmosfera de inovação e neste espírito de fazer do saber um bem comum que nasce o Departamento de Cultura, proposto e planejado por Paulo Duarte durante o mandato do prefeito Fábio Prado, entre 1934 e 1938.

Segundo Assis (2013, p.46), "os trabalhos do Departamento de Cultura do Município de São Paulo têm início em 30 de maio de 1935, a partir do Ato Municipal no 861". Quando Fábio Prado aprovou o plano estruturado por Paulo Duarte para a criação do Departamento, este impôs a condição que os Chefes de Divisão do Departamento seriam por ele (Duarte) indicados.

Assim, Mário de Andrade foi indicado para a Divisão de Expansão Cultural e para direção do Departamento. De acordo com Duarte (1985, p.6), "foi a minha insistência, mais do que isso, foi a minha exigência, a minha imposição que o demoveram”. Mário chegou ainda, em 1937, a ser representante em São Paulo do Departamento do Patrimônio Histórico e Artístico Nacional.

O Departamento de Cultura teve repercussão internacional. Cidades consideradas modelo em educação e cultura chegaram a se espelhar no Departamento para criar órgãos inspirados na atuação do mesmo. De acordo com Duarte (1985 p.60), "a cidade de Paris instituía uma organização cujas linhas gerais eram as linhas gerais do departamento paulista”. Além de Paris, cidades como Praga, Nova lorque e Buenos Aires também procuraram entender o funcionamento do Departamento para talvez aplica-lo em suas cidades.

O trecho a seguir da carta enviada à Mário de Andrade pelo professor de história latino-americana da Universidade de Standford, Percy Alvin Martin, em 1937, corrobora com a afirmativa do reconhecimento internacional do Departamento de Cultura:

I have examined this with much pleasure and I wish to congratulate you on the marvelous progress which the great municipality of Sao Pau- 
lo has taken for the welfare of its less privileged children. ${ }^{2}$

(Fonte: Acervo do Instituto de Estudos Brasileiros da USP)

Foram várias as cartas enviadas a Mario de Andrade parabenizando-o pelos feitos do Departamento de Cultura e por seus feitos para a população. Em carta, o autor gaúcho e contabilista do Banco do Brasil, Abeillard Barreto não só elogia ações consideradas pioneiras, como os parques infantis e a Revista do Arquivo Municipal, como explicita a importância e o cuidado tido pelo município de São Paulo em relação à educação e à cultura:

E é justamente de admirar que alguns anos depois o 'espirito renovador' venha a demonstrar, na direção de um Departamento como êsse a seu cargo, que a revolução tambem sabe construir! Além do mais, o Departamento de Cultura (que Deus o conserve!) se notabiliza pelas publicações, pela magnifica 'Revista do Arquivo Municipal', sem dúvida um dos maiores monumentos que registra a nossa imprensa periodica. Isto, no que é dado observar de longe. Vejo agora, porém, que há muitas cousas mais que se não conhecem: os parques infantis, por exemplo. E, assim, vai S. Paulo demonstrando ao Brasil quanto ha a fazer e quanto se póde realizar, desde que a inteligência e a cultura deem braço à operosidade. ${ }^{3}$ (Fonte: Acervo do Instituto de Estudos Brasileiros da USP)

Um dos exemplos acerca do esforço feito pelo Departamento de Cultura para incluir a massa operária nos programas culturais da cidade é o incentivo à apreciação de espetáculos teatrais, onde o Teatro Municipal seria aberto, pela primeira vez, para que os trabalhadores assistissem a peças voltadas para este público, gratuitamente e em dias específicos. Até então, o público do Teatro Municipal era formado pela alta burguesia, que podia pagar pelos ingressos. Este público condenou a iniciativa do Departamento, com receio que os operários depredas narra que:

2 Eu examinei isto com muito prazer e gostaria de parabeniza-lo pelo maravilhoso progresso realizado com o grande município de São Paulo para com o bem-estar das crianças menos privilegiadas. (tradução nossa)

3 Permanece a grafia original do documento. 
Se nos espetáculos acessíveis apenas à elite, com frequência, cadeiras e outras instalações eram danificadas com pontas de canivete ou lâmina de gilete, que dirá o Teatro entregue às massas populares que certamente nada respeitariam? Pois a surpresa foi sensacional: a gente do povo era muito mais educada do que a gente educada!... Nunca se verificou um estrago, um desrespeito durante aqueles espetáculos de música ou de teatro oferecidos especialmente aos operários, com entrada grátis. (DUARTE, 1985)

Nota-se, então, a importância do Departamento de Cultura para a criação e consolidação de uma identidade cultural e absorção da cultura pela população da cidade de São Paulo, numa época marcada pela ascensão e povoamento da cidade que estava se tornando o coração econômico do Brasil.

Dentre os principais pontos positivos trazidos pelo Departamento, fica a real preocupação em disseminar o acesso à cultura e à educação para a população, o reconhecimento no país e internacionalmente do Departamento de Cultura e, para esta pesquisa, a preocupação em criar-se uma biblioteca voltada especificamente para o público infantil.

Durante o período em que Mário de Andrade foi diretor do Departamento de Cultura, a Divisão de Bibliotecas ficaria a cargo de Rubens Borba de Moraes, renomado pesquisador no campo da bibliografia. Entre o período de 1935 a 1943, Moraes foi também diretor da atualmente conhecida como Biblioteca Pública Municipal Mário de Andrade. Segundo Reipert (1972, p. 21), "Foi Rubens Borba de Morais um diretor dinâmico e a êle deve a Biblioteca a sua reorganização, que a torna um laboratório da inteligência dentro de São Paulo”.

De acordo com o artigo 4 do Regulamento do Departamento de Cultura 4 (sem data), a divisão de Bibliotecas constitui-se de uma subdivisão e duas secções técnicas, a que estão afetos os seguintes serviços:
a) Biblioteca Pública Municipal;
b) Bibliotecas Populares;
c) Bibliotecas Infantis;

4 Fonte: Documento cedido para pesquisa pelo Instituto de Estudos Brasileiros da USP 
d) Bibliotecas Circulantes;

e) Bibliotecas de Parques.

De acordo com o Artigo 102 do mesmo Regulamento, incumbe à Divisão de Bibliotecas:

10) - criar e organizar os serviços municipais de bibliotecas públicas;

$2^{\circ}$ ) - organizar concursos literários de toda espécie, tendentes a incentivar a cultura nacional e completá-la em suas deficiências;

$3^{\circ}$ ) - orientar os serviços de catalogação, classificação e conservação dos livros;

$4^{\circ}$ ) - procurar e manter intercâmbio com bibliotecas nacionais e estrangeiras;

$5^{\circ}$ ) - organizar e dirigir anualmente um curso de biblioteconomia;

$6^{\circ}$ ) - divulgar mensalmente os dados estatísticos relativos ao movimento de consultas, entrada de livros e revistas

Dentre estes, é importante ressaltar que este curso anual de formação em biblioteconomia foi de suma importância para capacitar as pessoas que viriam a trabaIhar nestas bibliotecas, visto que não existiam curso com tanta especificidade na área.

Quanto as bibliotecas populares, que teriam como objetivo atender ao público que morasse mais afastado do centro da cidade para que este não precisasse se deslocar até o centro para fazer uso das bibliotecas, infelizmente foi um plano que não saiu do papel.

\subsection{A BIBLIOTECA INFANTIL DE SÃO PAULO}

"As bibliotecas infantis, centros de larga irradiação cultural, partes indispensáveis dum sistema de educação, reúnem tríplice finalidade: social, moral e intelectual. " Esta afirmação, hoje de conhecimento de qualquer profissional envolvido com educação, cultural ou biblioteconomia, foi feita por Lenyra Fraccaroli, em 1940, no documento escrito por ela para o Departamento de Cultura, que aborda as finalidades de uma biblioteca pública infantil e como esta deve ser, em termos de atividades, instalações e catalogação do acervo.

Antes de se tornar diretora da Biblioteca Infantil de São Paulo, Fraccaroli teve vasta experiência enquanto bibliotecária em uma escola paulista, onde iniciou 
suas práticas organizacionais para este tipo de ambiente, zelando por construir um espaço onde as necessidades do usuário, no caso a criança em idade escolar, fossem verdadeiramente atendidas.

No documento para o Departamento de Cultura sobre bibliotecas infantis, a autora explicita, acerca deste tipo de ambiente e ao que serve, que devem (ter) "muita luz, bastante ar, salas espaçosas e de pintura sugestiva à imaginação infantil, quadros e cartazes vistosos, estantes acessíveis, livros produtivos de belo colorido." e que

a criança deve sentir-se bem, perfeitamente a vontade, ter a impressão de estar num ambiente todo seu, onde a sua natural curiosidade seja satisfeita e os seus desejos acolhidos com extremo carinho e solicitude, porque numa biblioteca infantil encontram-se duas forças que se conjugam: a atividade da criança e a influência orientadora da bibliotecária.

(FRACCAROLI 1940, p.293)

Com estas afirmações feitas há quase oitenta anos, Fraccaroli apresenta aspectos voltados para bibliotecas infantis que não apenas se mostram inovadores para a época em que foram pensados, mas que ainda norteiam, de certa forma, os critérios dos profissionais que lidam com este tipo de ambiente.

Inaugurada oficialmente em 1936, em um casarão na rua Major Sertório, a Biblioteca Infantil tinha, sob a gestão de Fraccaroli, diversas atividades voltadas para seu público, consideradas inovadoras em suas características e em seu modelo de atendimento ao público, conforme afirma Andreotti no trecho a seguir:

O projeto da Biblioteca Infantil foi considerado de vanguarda, pois abrigava características de um centro cultural em torno do livro e da leitura, como confirmam suas primeiras atividades: sessões de cinema sonoro, exposições de selos e moedas, concurso infantil de pintura, hora do conto e um jornal feito pelas crianças. Foi também o embrião de outras bibliotecas infantis na cidade, no estado de São Paulo e em outras capitais do país, tamanha a repercussão quanto à sua cria ção e funcionamento. (ANDREOTTI, 2005, p.163) 
Sobre a organização espacial da Biblioteca nesta época, não há muitos registros que possam colaborar para uma análise mais aprofundada do local, porém, observando-se imagens da época da inauguração da Biblioteca, considerase que, apesar de seu intuito inovador e revolucionário, o local não apresentava mobiliários projetados especificamente para as crianças atendidas, que tinham que se adequar ao que era oferecido. Tal situação se justifica muito mais pela época vivida, em que o mobiliário voltado para o público infantil estava mais restrito a projetos voltados para o quarto da criança ou para salas de aula.

Observa-se na Figura 1 que as crianças fazem a leitura, apesar de individual, em mesas grandes e redondas, que possibilitam socialização entre elas.

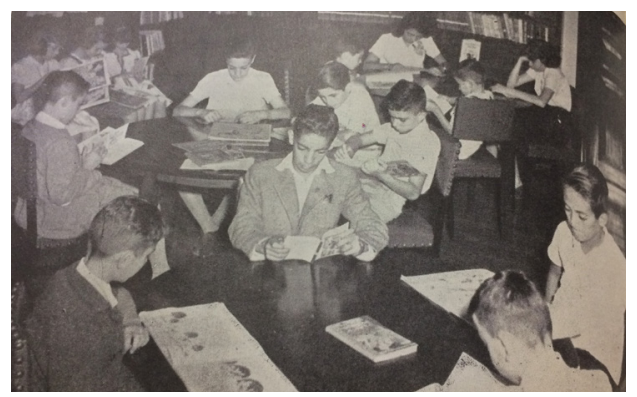

Figura 1 - Sala de Leitura da Biblioteca Infantil Fonte: Acervo da Biblioteca Infantojuvenil Monteiro Lobato

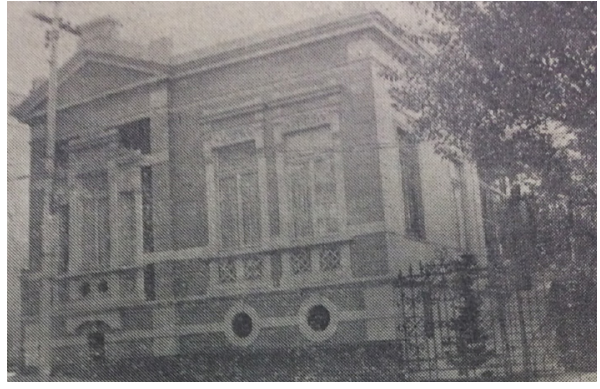

Figura 2 - Fachada da primeira sede da Bibliteca Infantil na Rua Major Sertório Fonte: Acervo da Biblioteca Infantojuvenil Monteiro Lobato

A Figura 2 aponta para a fachada da primeira localização da Biblioteca que, devido ao grande número de acesso de crianças diariamente, já não comportava a quantidade de usuários, mudando-se para uma chácara no terreno da atual localização da Biblioteca. Esta chácara abrigou as atividades da Biblioteca, até que em 1950 houve a construção do atual prédio da instituição.

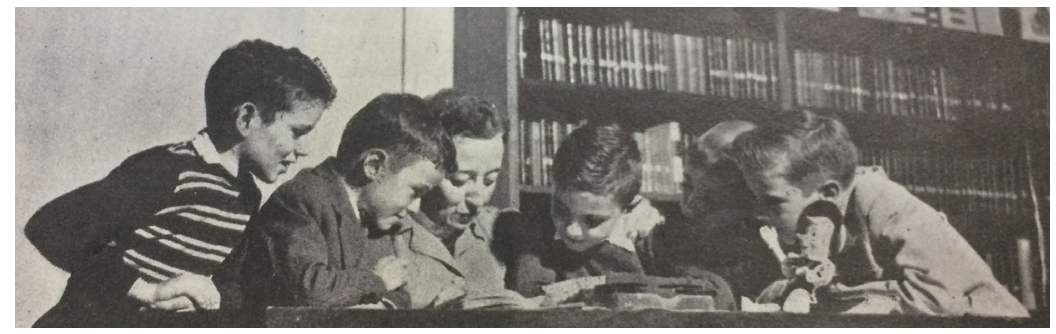

Figura 3 - Contação de histórias para as crianças Fonte: Acervo da Biblioteca Infantojuvenil Monteiro Lobato 
As imagens abaixo não podem fornecem muitas informações acerca da organização espacial da biblioteca e de seus equipamentos, porém é possível tecer comentários sobre a diversidade de atividades oferecidas pela Biblioteca, inclusive deve-se ressaltar a importância do jornal "A voz da infância", no qual as crianças participavam de todas as etapas de sua construção (ver Figura 6), desde a escrita até a impressão do mesmo, tipo de atividade excelente para instigar a curiosidade investigativa da criança e dar a ela protagonismo em relação ao uso da biblioteca que a elas pertence.

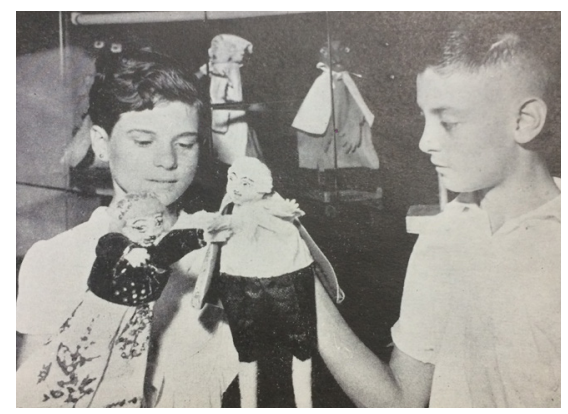

Figura 4 - Crianças interagem com fantoches na década de 1940

Fonte: Acervo da Biblioteca Infantojuvenil Monteiro Lobato

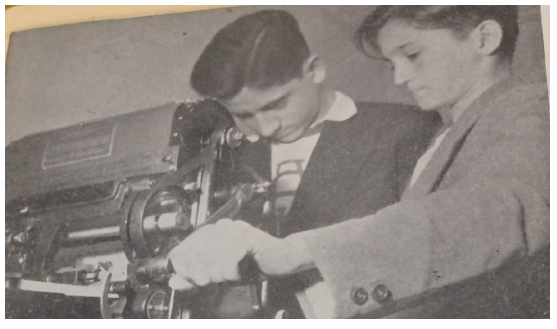

Figura 6 - Crianças produzindo o "Jornal da Infância” na Biblioteca, década de 1940

Fonte: Acervo da Biblioteca Infantojuvenil Monteiro Lobato

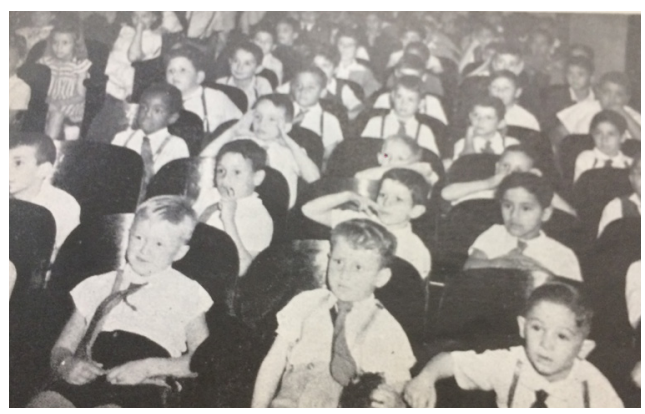

Figura 5 - Sala de Teatro da Biblioteca, década de 1940

Fonte: Acervo da Biblioteca Infantojuvenil Monteiro Lobato

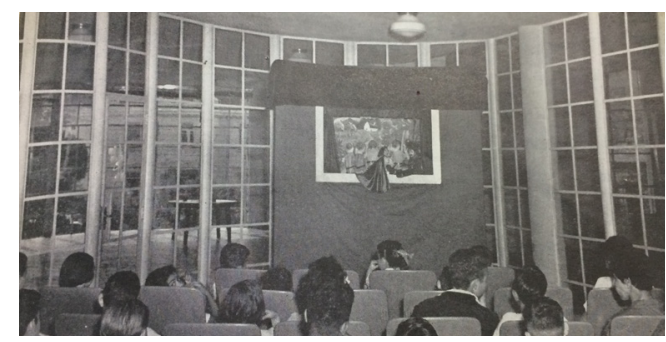

Figura 7 - Sala para teatro de fantoches e teatro de sombras, década de 1940

Fonte: Acervo da Biblioteca Infantojuvenil Monteiro Lobato

Sobre o mobiliário que pode ser observado, nota-se que as crianças estão sentadas em cadeiras cujas proporções antropométricas não condizem com a deste público, porém este tipo de cuidado ainda não existia na época. 
A Biblioteca foi batizada Biblioteca Infantojuvenil Monteiro Lobato (BIJML) no ano de 1955, para homenagear seu patrono, que tinha como parte de sua rotina contar histórias para as crianças nos antigos casarões que abrigavam a Biblioteca em seus primórdios.

Com o passar das décadas, a dinâmica da BIJML foi mudando, algumas de suas antigas atividades foram sendo encerradas, porém a biblioteca nunca perdeu seu valor simbólico para a cidade, sendo constantemente notícia nas mídias, como mostram os recortes de jornais a seguir:

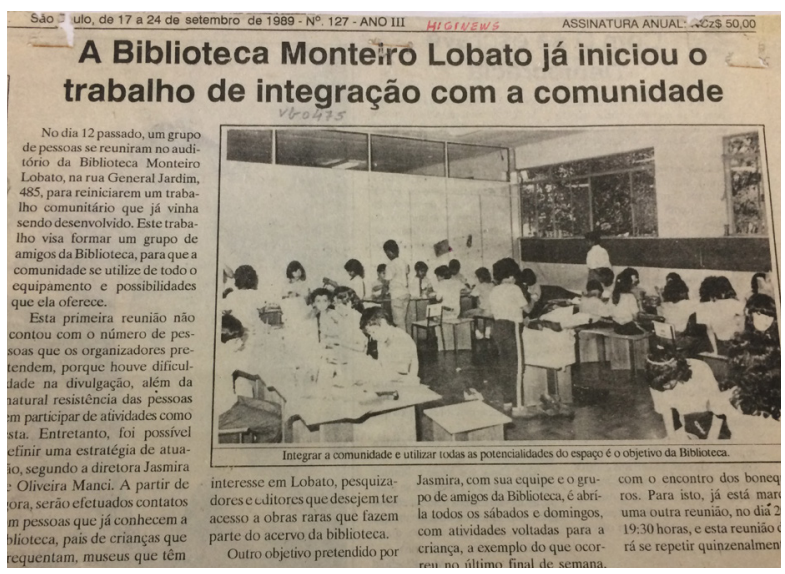

Figura 8 - Matéria em jornal, 2006, aponta para a diversidade de atividades oferecidas pela biblioteca, sua história e acervo e mostra na imagem um dos espaços, ressaltando que brinquedos dividem espaço com livros nas estantes. Fonte: Acervo da Biblioteca Infantojuvenil Monteiro Lobato

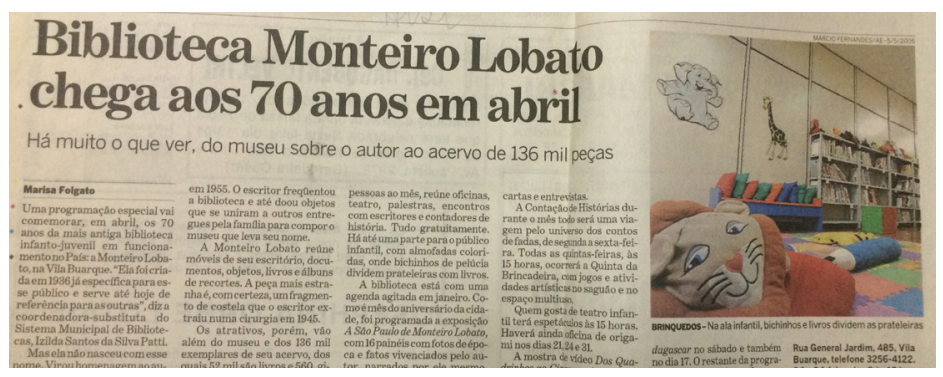

Figura 9 - Matéria no Jornal de Higienópolis, 1989. A chamada da fotografia anuncia: "Integrar a comunidade e auxiliar todas as potencialidades do espaço é o objetivo da biblioteca.

Fonte: Acervo da Biblioteca Infantojuvenil Monteiro Lobato 


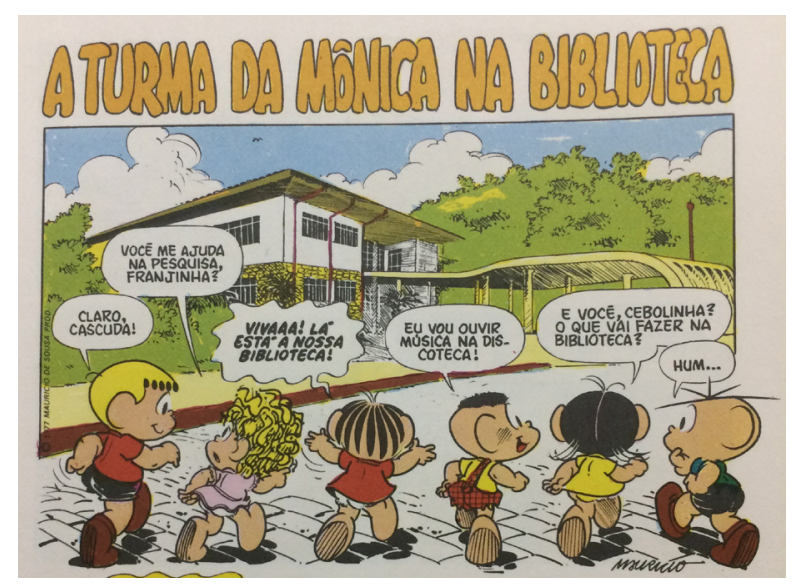

Figura 10 - Gibi especial da Turma da Mônica conhecendo a Biblioteca Infantojuvenil Monteiro Lobato, anos 1970. É possível observar a entrada da biblioteca que foi ilustrada inspirada na real construção.

Fonte: Acervo da Biblioteca Infantojuvenil Monteiro Lobato
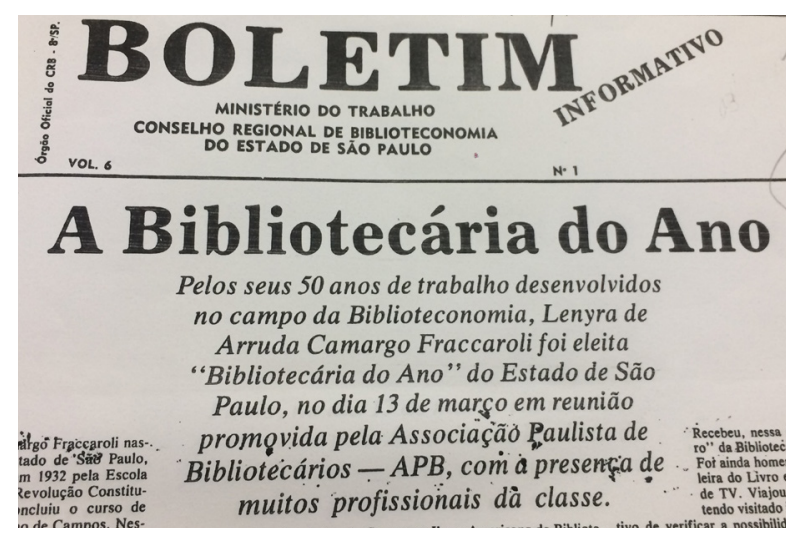

Figura 11 - Boletim informativo do Conselho Regional de Biblioteconomia do Estado de São Paulo homenageando Lenyra Fraccaroli por seus 50 anos de trabalho realizados no campo da Biblioteconomia.

Fonte: Acervo da Biblioteca Infantojuvenil Monteiro Lobato

Esta compilação de notícias retiradas de diversos anos teve como objetivo reforçar a importância do trabalho de Fraccaroli, o valor simbólico que apresenta a Biblioteca Infantojuvenil Monteiro Lobato e também sua real importância enquanto centro cultural e de lazer para a cidade. 
CAPÍTULO 2
BIBLIOTECA 


\subsection{BIBLIOTECA: RELEVÂNCIA SOCIAL E TIPOS}

Neste capítulo, serão abordados aspectos referentes às funções das bibliotecas por tipologia, em especial, as bibliotecas de caráter infantil, escolares ou não, pois trazem consigo elementos essenciais ao desenvolvimento da criança, que extrapolam as atividades específicas de formação e informação, como significados e percepções que colaboram para a construção do cidadão.

Aqui, serão discutidos alguns aspectos que justificam o investimento público em qualificar os ambientes das bibliotecas: como dispositivo cultural, é um espaço onde a criança pode exercer sua liberdade de aprender temas que deseje, sem amarras escolares, tornando-se protagonista de seu aprendizado.

A biblioteca é um centro de informação, cultura e conhecimento. No passado, teve funções restritas ao depósito, guarda e conservação de documentos, conforme explicitado no Capítulo 1 deste documento. Na contemporaneidade, assume papel fundamental para a educação, no fomento à leitura e na formação do cidadão, principalmente de crianças do pré-escolar adolescência, acompanhando a sequencia do sistema educacional de ensino fundamental até o médio.

Este estudo tem como foco as bibliotecas infantis escolares, as publicas e de natureza institucional com acesso facilitado, considerando-as como centros dinâmicos de informação e de formação, vinculada ao processo ensino-aprendizagem, interagindo com a sala de aula no caso das bibliotecas escolares, num ambi- 
-ente repleto de possibilidades literárias que aguçam a imaginação. Nos casos da biblioteca infantil pública ou institucional, onde não há relação direta com a escola, podendo agregar outras atividades socioculturais.

Alguns autores colocam ainda que a biblioteca estimula a criatividade, a construção de conhecimentos; dá suporte à capacitação de professores, à educação permanente, à qualificação do ensino. Contribui para a formação integral do indivíduo, capacitando-o a viver em um mundo em constante evolução. (ANTUNES apud. MACEDO, 2005, p.169).

Neste sentido, viabiliza a produção do conhecimento aos seus usuários a partir do crescimento de seu repertório cultural, do acesso a outras visões de mundo que possibilitem estabelecer novas relações com a sociedade que a cerca.

A seguir, apresenta-se algumas colocações sobre os tipos de bibliotecas, focando-se principalmente na escolar e na pública, ambas voltadas para o público infantil e objetos de interesse desta pesquisa. Apesar de possuírem diversos objetivos e funções convergentes, estas apresentam funções referenciadas à tipologia destes equipamentos e podem ser caracterizados por suas particularidades.

De acordo com o Sistema Nacional de Bibliotecas Públicas (SNBP), de domínio do governo federal do Brasil, as bibliotecas são classificadas de acordo com suas funções e serviços, com a comunidade que atende e por seu vínculo institucional. O SNBP classifica as bibliotecas em nove tipos, cujas informações a seguir sobre suas tipologias foram extraídas do site do governo federal do Brasil:

- biblioteca pública - atende a todos os públicos concernentes à comunidade na qual está inserida e obedece os preceitos estabelecidos no Manifesto da IFLA/ Unesco sobre bibliotecas públicas;

- biblioteca pública temática - são as bibliotecas públicas que possuem acervos especializados ou que oferecem atendimento especializado a um determinado público sendo, desta forma, identificada por tal público, como é o caso da bibliotecas pública infantil;

• biblioteca comunitária - sua criação e manutenção estão vinculadas à comunida- 
de local, sem vínculo direto com o estado;

-pontos de leitura - espaços criados em comunidades, fábricas, hospitais, presídios, dentre outras instituições com o objetivo de incentivar a leitura;

-biblioteca nacional - em cada país existe uma Biblioteca Nacional, cuja função é reunir e preservar toda a produção bibliográfica do país. No Brasil, está sediada no Rio de Janeiro;

-biblioteca escolar - atende os interesses de leitura e informação de sua comunidade, trabalhando em consonância com o projeto pedagógico da escola na qual está inserida. Segue os preceitos do Manifesto da IFLA/Unesco para a biblioteca escolar;

- biblioteca universitária - é vinculada a uma unidade de ensino superior, podendo ser uma instituição pública ou privada e dá continuidade ao trabalho iniciado pela biblioteca escolar;

-biblioteca especializada - voltada a um campo específico do conhecimento, é vinculada a uma instituição pública ou privada;

-biblioteca/centro de referência - bibliotecas especializadas que atuam com foco no acesso, disseminação, produção e utilização da informação para um determinado público.

Dos tipos de biblioteca que existem, seguindo a classificação do SNBP, esta pesquisa restringirá seu olhar para as classificadas como "biblioteca pública infantil" e como "biblioteca escolar".

\subsection{BIBLIOTECA PÚBLICA INFANTIL E ESCOLAR - ESPECIFICIDADES E SIMILARIDADES}

De acordo com Milanesi (2002, p.56), as crianças aparentam ser o público mais complexo do ponto de vista dos serviços de informação, além de ser o que 
mais exige cuidados e atenção por parte da equipe da biblioteca, pois é o cidadão do futuro que será moldado em função dos estímulos que recebe. Nesse aspecto, bibliotecas cumprem papel relevante e podem ser consideradas como ambientes educadores, nos quais o espaço e seus componentes físicos e perceptivos; os acervos e materiais diversos, além de móveis, equipamentos e objetos que os compõem colaboram para a formação integral do cidadão, incluindo cultura, socialização e educação .

Neste sentido, Andrade em Campello (2008) atribui à biblioteca valor cultural, e aponta a necessidade de se criarem oportunidades para que as crianças acessem os bens culturais da região onde vivem, a fim de ampliar o desenvolvimento do que o autor denomina de capacidades estéticas, de pensamento, de expressão, de comunicação e de interação social, entendendo que estas congregam também atitudes éticas.

As bibliotecas públicas e as escolares tratadas nesta dissertação se inserem dentro de uma tipologia adotada em políticas, associações e organizações desta área de atuação, com competências e atividades estabelecidas de acordo com usuários, recursos e situações diversificadas. A infantil pública tem acesso livre e gratuito, oferecendo acervo e serviços de leitura e informação para a comunidade em que está localizada. Como um equipamento cultural, está inserida nas políticas públicas do Ministério da Cultura (MinC), sendo gerenciada e mantida pelo Estado.

Já a escolar atende aos interesses de leitura e informação segundo orientações e diretrizes da unidade de ensino e estão previstas em todo território nacional pela lei federal no 12.244 de 24 de maio de 2010. Sua principal função, de acordo com Melo e Neves (2008, p.6), é a de "incentivar e estimular a aprendizagem, a criatividade, e a comunicação da criança e do adolescente daquela instituição ou sociedade em que está inserida”.

Estas duas tipologias têm em comum atividades culturais entre as quais se ressaltam as mais presentes: a hora do conto, jogos educativos e recreativos, teatrinho, exposições temáticas e até cineminha.

Sobre a relação da criança com este ambiente, Milanesi (2002, p.61), numa visão progressiva e encadeada de usos e experiências, afirma que há uma sequên cia de familiarizações com este espaço, sendo que após adquirir intimidade com a biblioteca infantil, a criança começa a ser inserida no ambiente da escolar. Entretanto, considera-se que esta afirmação pode não encontrar correspondência na o- 
ferta atual de bibliotecas para crianças em cidades como São Paulo, escopo físico desta pesquisa, onde por vezes a situação contrária é a que prevalece. Isto se acentua em alguns casos onde o autor ressalta como problema agravante a falta de preparo, especialmente o físico, para receber os adolescentes nas bibliotecas escolares, o que ajuda a tornar o local um símbolo não de prazer, mas de castigo. Desta forma, reforça a necessidade e a importância da adequação do espaço ao público que o usa, evitando o risco de tornar o local um ambiente estranho ao usuário.

Na categoria escolar, se estiver associada apenas a servir de anexo da sala de aula, como espaço adjacente, complementar, contendo o mínimo de materiais, acervo, e programações a biblioteca escolar começa a perder sua importância, ou até seu protagonismo na qualidade de ambiente educador. Porém, se bem estruturada, este tipo de biblioteca pode, por si só, servir de dispositivo educacional, atuando como espaço onde os saberes transitam e se encontram com seus usuários.

As bibliotecas infantis do tipo públicas estão disponíveis para todas as crianças que habitam ou frequentam seu entorno. Já as bibliotecas escolares se restringem, em sua maioria, aos alunos de determinada instituição. Independentemente da sequência de contato, conhecimento e frequência da criança a estes tipos de equipamento, adquirindo vivência em bibliotecas escolares e/ou públicas que apresentem qualidades ambiental, espacial, informacional, formativa, e de conhecimento, o futuro adulto estará familiarizado com este bem cultural.

Desta forma, é possível compreender a importância de ambos os tipos de biblioteca, dispositivos estes que abrigam aquilo que Milanesi (2002) considera um bem desejável e essencial para alavancar o desenvolvimento de uma sociedade: a informação.

\subsection{A INFORMAÇÃO NA CONTEMPORANEIDADE - SOCIEDADE DA IN- FORMAÇÃO}

A sociedade atual é classificada por alguns como sociedade da informação, cujas características designam "uma sociedade na qual, a informação, apoiando-se sobre as possibilidades oferecidas pelas Tecnologias de Informação e da comunicação (TIC) tem papel central na vida econômica, social, cultural e política”. 
(La Société de l'information: glossaire critique, 2005)

As últimas décadas trouxeram adventos tecnológicos que mudaram a organização mundial, a forma como nos comunicamos e registramos a informação. Com a invenção do computador (hoje instrumento com o qual parte considerável da população se informa) e, mais recentemente com a chegada e difusão da internet, a forma como repassamos, recebemos e armazenamos a informação mudou.

A informação, de acordo com Coadic, comporta um elemento de sentido. Assim, para o autor, o objetivo da informação é o conhecimento.

Um conhecimento (um saber) é o resultado do ato de conhecer, ato pelo qual o espírito apreende um objeto. Conhecer é ser capaz de formar a ideia de alguma coisa; é tê-la presente no espírito. Isso pode ir da simples identificação (conhecimento comum) à compreensão exata e completa dos objetos. (COADIC, 1994, p.4)

Na chamada "Sociedade da Informação", onde temos a forte presença das tecnologias da informação, muda-se a forma de produzir, distribuir e receber cultura. Neste contexto, vivemos uma época de "avalanche informacional", onde não temos condições de filtrar e compreender toda a carga de informações cotidianamente "jogadas" para nós. Perrotti e Pieruccini apontam para esse excesso de informações, ressaltando a importância de se apropriar da informação na contemporaneidade.

Nestes termos, é preciso construir tais recursos e deles nos apropriarmos, como condição de navegação nas águas agitadas e turvas da informação na contemporaneidade. Informação que, nesse ponto, encontra-se com a Educação, uma vez que a apropriação dos bens simbólicos não é ato simplesmente natural, mas culturalmente construído. (PERROTTIi \& PIERUCCINI 2007, p.53)

Os mesmos autores colocam que se a informação é agora um objeto autônomo, ou um produto, isto requer mudanças na forma como encaramos a transmissão e a recepção da mesma, e neste aspecto cabe pensar que os ambientes construídos existentes deve também ser repensados para abrigar, difundir, e faci- 
litar apropriação da informação pelos cidadãos. Esta colocação se rebate diretamente nos ambientes de bibliotecas onde os vários elementos que a compõem desde os móveis e equipamentos, passando pela iluminação até os suportes e a comunicação visual, devem estar em perfeita harmonia com os objetivos do espaço construído, para atender da melhor forma possível às necessidades do usuário.

A noção de ambiente construído, como espaço projetado e edificado para o desenvolvimento das atividades humanas, vem carregada de valores que remetem, ou não, a um lugar bom de se ficar, de aprender, de brincar, de conhecer e de se relacionar. (TARALLI 2006, p.6)

De acordo com Campello (2008, p.9), faz-se necessário preparar as crianças e os jovens para viver em nossa sociedade, caracterizada como contraditória e fluida, sendo um destes apoios o uso da informação. Além disso, a autora afirma que é parte do papel pedagógico da biblioteca poder participar de forma criativa do esforço de preparar o cidadão do século XXI.

O modelo ideal de sociedade, no que diz respeito ao papel da informação, seria aquela na qual

cada um tenha a possibilidade de criar, de obter, de utilizar, de partiIhar a informação e o saber e na qual os indivíduos, as comunidades e os povos possam assim desenvolver todas as suas potencialidades, meIhorando sua qualidade de vida, de acordo com seus objetivos.

(La Société de l'information: glossaire critique, 2005)

Neste sentido, na biblioteca, a consulta, a leitura, e as programações complementares que colaboram para vivenciar, promover trocas e aquisições de conhecimentos, repertório e experiências através de historias e autores, se colocam ao lado, e com a mesma importância, da informação farta, disponível, consumível ofertada pelas tecnologias digitais. Esta última é fundamental para a educação e a formação, e saber procurar, filtrar e trabalhar com ela constitui matéria base da Infoeducação. 


\subsection{INFOEDUCAÇÃO, PROTAGONISMO JUVENIL E APROPRIAÇÃO DA INFORMAÇÃO}

Na Era da Informação, não basta ter acesso à informação, ao conhecimento. Se antes visava-se a necessidade de renovar, de criar instituições culturais que dessem acesso ao conhecimento, esta já não é a preocupação dos dias atuais. De acordo com Perrotti e Verdini (2008), a distribuição de livros, que não necessariamente resultam no acesso à leitura, não consideram a dimensão simbólica dos bens culturais.

Neste sentido, a Infoeducação, área de estudos e contribuição científica reconhecida internacionalmente advinda de estudos realizados por pesquisadores da Escola de Comunicação e Artes da USP, centrada nas relações entre Informação e Educação, tem em vista o domínio de saberes que, até então, não eram tidos como essenciais no processo de formação.

A infoeducação propõem, dentre outros aspectos, novos modos de aprender, de se apropriar da informação, nomear questões teóricas e práticas resultantes de pesquisas, visando abordage, transdisciplinar e dinâmica, reconhecendo a complexidade dos saber e fazeres informacionais.

Os fenômenos informacionais e educacionais não se separam, apesar de apresentarem autonomia e identidades próprias. Os dispositivos e as aprendizagens informacionais são, parte de um todo articulado que está na base dos processos de significação. (PERROTTI, 2008)

Ao contrário das salas de aula habituais, na biblioteca o aluno acessa diferentes fontes de informação. Nesta, a educação é aberta, imparcial. A escola reúne tempo e espaço; as novas tecnologias mudam as dimensões de tempo e espaço. As bibliotecas deveriam estar aptas a assimilar, trabalhar e colocar a disposição do público, inclusive o infantil, não só conteúdos (informacionais e educacionais), como os meios, os recursos e os dispositivos que possibilitam as interações destes com os usuários, incluindo os componentes do espaço, o mobiliário e demais produtos essenciais para seu funcionamento. 
O protagonismo da criança em sua busca pelo conhecimento é essencial aos preceitos da Infoeducação. De acordo com Ferretti (2004), o jovem é formado como cidadão por meio do protagonismo. Neste sentido, Costa (2011) explicita o protagonismo como a participação do aluno no enfrentamento de situações reais na escola, na comunidade e na vida social mais ampla.

É preciso, portanto, criar espaços e condições, ainda de acordo com o autor, que propiciem ao jovem empreender a construção de seu ser em termos pessoais e sociais. Para tanto, faz-se necessário um modelo educativo onde a própria criança tenha participação autêntica, não simbólica na busca pelo conhecimento.

Neste sentido, esta pesquisa buscou também compreender se houve nas bibliotecas vistas nos estudos de caso do Capítulo 4, por parte das crianças, uma real apropriação do local e dos equipamentos que estes disponibilizam, na experiência do usuário em um ambiente destinado à busca pelo conhecimento e constituído basicamente de informações, no formato de acervo das bibliotecas em questão; e se estes tinham autonomia no local para utilizar o espaço, o mobiliário e os equipamentos ali existentes da forma que sentissem vontade.

\subsection{BIBLIOTECA - DISPOSITIVO CULTURAL}

O conceito de dispositivo levado em consideração neste estudo é o adotado por Foucault, que o coloca no centro dos processos de mediação.

\footnotetext{
O conceito de 'dispositivo' foi prioritariamente desenvolvido por Foucault para o campo das Ciências Sociais, implicando noção de intencionalidade, de ação realizada por pessoas ou materiais, tendo em vista um objetivo a ser atendido. (PIERUCCINI, 2004, p.34)
}

A autora usa o termo dispositivo cultural para contextualizar o papel da biblioteca na contemporaneidade, frente à complexidade dos meios e conteúdos da informação, nem sempre claros e explícitos, e complementa com os argumentos: 
No novo contexto, as formas de transmissão direta de informação ocorrem, cada vez mais, com formas indiretas, mediadas por instâncias de naturezas e dinâmicas diversificadas, definidas por estudiosos da cultura como dispositivo. (PIERUCCINI, 2009, p.24)

Neste sentido, considera-se a biblioteca como um dispositivo cultural carregado de intenções, programações e ações para o seu funcionamento material e simbólico. O espaço da biblioteca pode ser compreendido, portanto, como dispositivo onde ocorrem processos de infoeducação e, por conseguinte, para a apropriação da informação.

Considera-se que a configuração da biblioteca, constituído de produtos materiais e imateriais, tem em si um discurso implícito. Desta forma, ratifica-se a necessidade de estudo acerca dos arranjos físicos, espaciais, dos objetos e produtos que a constituem; dos materiais de acervo e informação e sua interação com os usuários e atividades voltadas para o público infantil, pois é nestes dispositivos que as crianças poderão vir a se apropriar de seus recursos, acumulando e desenvolvendo conhecimentos em sua formação e socialização.

A biblioteca escolar habilita os estudantes para a aprendizagem ao longo da vida e desenvolve sua imaginação, preparando-os para viver como cidadãos responsáveis. (Manifesto Unesco/Ifla para a biblioteca escolar, p. 419 apud Macedo, p. 168).

De acordo com Taralli (2007, P.7), faz-se necessário tornar o espaço da biblioteca apropriado para atender este público, capaz de ajudá-lo a desenvolver seu aprendizado e para que estimule a participação ativa de todos os atores da comunidade escolar.

No ambiente construído para a biblioteca, o espaço é qualificado e organizado pelas relações de interação entre o indivíduo e os grupos, os recursos tecnológicos, as mídias audiovisuais, a informação, o acervo impresso e digitalizado, e os processos de estratégias pedagógicas e culturais. 
Acerca das necessidades de se alterar a organização do espaço físico da biblioteca escolar, em atenção às mudanças tecnológicas e à inserção dos suportes eletrônicos de informação, Milanesi (2002, p.60) aponta que

\begin{abstract}
A criança não só absorve os conteúdos, mas se manifesta sobre eles, desenvolvendo também a capacidade de compreendê-los, criticá-los e de inventar novos conteúdos. O espaço físico para as crianças deve ser, pois, mutante, com áreas para o acervo, que não exige nenhuma sofisticada técnica de organização, e áreas para todas as formas de ações individuais ou de grupo, objetivando desenvolver a capacidade criativa.
\end{abstract}

O próximo capítulo aborda e analisa exemplos de alguns espaços de bibliotecas que se destacam positivamente nos quesitos de configuração ambiental, com aspectos lúdicos e linguagem espacial e material que aguçam ao interesse e a imaginação, contribuindo na interação com a criança e demais usuários. Serão apontadas algumas características que os tornam ambientes qualificados para receber crianças, além de uma compilação de mobiliários voltados para bibliotecas infantis disponíveis no comércio. 


$$
\begin{aligned}
& \text { CAPÍTULO } 3 \\
& \text { ESTADO DA } \\
& \text { ARTE }
\end{aligned}
$$




\subsection{APRESENTAÇÃO}

O presente capítulo buscou inteirar-se acerca da atual oferta, por parte da indústria moveleira, de produtos voltados para bibliotecas e para ambientes escolares, bem como analisar aspectos referentes ao ambiente físico e de seus componentes em bibliotecas infantis de acesso público consideradas inovadoras em suas propostas de ambientação.

Dividido em dois sub-tópicos, este capítulo tem como principais objetivos compreender o cenário das opções de mobiliário infantil para ambientes de ensino, com o intuito colaborar com a investigação da situação dos mobiliários e equipamentos dos estudos de caso, encontrados no Capítulo 4 desta dissertação, antecipando aqui tratar-se de ambientes contemporâneos em uso. Além disso, a análise das bibliotecas consideradas inovadoras em suas ambientações tem como objetivo apontar características que podem, ou não, estar também presentes nos estudos de caso já citados, observando-se aspectos presentes em ambientes considerados bem resolvidos em suas propostas.

\section{2 - MOBILIÁRIO INFANTIL PARA ESCOLAS E BIBLIOTECAS}

Inicialmente, buscou-se compilar e analisar unicamente mobiliários perti- 
nentes à biblioteca infantil ou escolar, por se tratar do tema que rege esta pesquisa. No entanto, após as primeiras buscas, ficou clara a deficiência em termos não só de diversidade mas também de existência no que concerne a oferta deste tipo de produto pela indústria. Assim sendo, foram incluídos na pesquisa mobiliários pertinentes à escola, mas que podem ser encontrados em bibliotecas infantis públicas ou privadas e escolares, conforme observado nos estudos de caso desta dissertação e em pesquisa de campo prévia para apurar a situação de bibliotecas infantis e escolares.

\subsubsection{CRITÉRIOS PARA AVALIAÇÃO DOS MOBILIÁRIOS}

Foram levados em consideração aspectos ergonômicos, antropométricos e a norma NBR 14006 da ABNT para mobiliário escolar para avaliar a pertinência dos produtos analisados, no que diz respeito à relação de suas medidas com a idade do público a quem estes produtos são destinados. Além disso, buscou-se também discorrer sobre a diversidade de materiais e cores oferecidos pelas empresas selecionadas.

\subsubsection{AS EMPRESAS}

A busca por estes produtos foi realizada majoritariamente via pesquisa em sites, justificada pela impossibilidade de se visitar as fábricas ou escritórios das empresas em questão, seja por razões de deslocamento geográfico ou pela indisponibilidade por parte das empresas em colaborar com a presente pesquisa. Algumas informações acerca dos produtos foram cedidas via conversa telefônica ou via e-mail com algumas das empresas em questão.

No total, foram compilados produtos originários de nove empresas brasileiras, o principal critério para sua escolha foi o conhecimento acerca da popularidade das mesmas, no sentido que fornecem seus produtos para um grande número de franquias de estabelecimentos públicos ou privados relacionados ao campo da educação ou que apresentassem uma gama considerável de produtos com diversidade em materiais e públicos atendidos.

O quadro que apresenta as empresas em questão, ressaltando-se que todas as informações sobre elas está presente no Apêndice 1. 
A apresentação das empresas foi inserida para validar a escolha das mesmas, além de servir como indicador dos aspectos que importam para elas em relação ao projeto de mobiliários escolares e de bibliotecas.

Os mobiliários escolhidos nos sites foram aqueles que, de alguma forma, se relacionavam com a dinâmica de bibliotecas escolares ou infantis, em sua maioria: cadeiras, mesas, estantes, expositores e revisteiros. Foram levados em consideração apenas mobiliários voltados para o público analisado por esta pesquisa, ou seja, crianças entre seis e nove anos.

Dentre os aspectos pertinentes aos produtos, foram escolhidos "dimensões", "composição" e "cores disponíveis" para análise dos mesmos, por se tratarem de informações que propiciam um debate acerca das possibilidades apresentadas.

Na sessão de Apêndice desta dissertação, podem ser encontrados os quadros que apresentam a compilação dos mobiliários pesquisados e avaliados como importantes para a pesquisa. Foram registradas informações acerca das dimensões dos produtos, as cores disponíveis e os materiais que os compõem.

Os espaços em branco nos quadros indicam que, apesar da pesquisa nos sites e do contato via telefone ou e-mail com as empresas em questão, não foram apuradas as informações pertinentes ao produto. Contudo, optou-se por apresentar o mobiliário, por considerá-lo importante, por razões particulares em cada produto, para a pesquisa.

\subsubsection{ANÁLISE ACERCA DAS DIMENSÕES DOS PRODUTOS - CADEIRAS E MESAS}

\subsubsection{Dimensões dos produtos:}

É de extrema importância para a saúde física e para um bom desempenho das atividades desenvolvidas pelo usuário que os equipamentos em questão estejam em consonância não apenas com as normas técnicas regentes no país, mas também com aspectos pertinentes à ergonomia e à antropometria.

Uma forma resumida de se explicar a ergonomia é a dada pela Associação Internacional de Ergonomia, que diz que a ergonomia trata-se de uma disciplina orientada para uma abordagem sistêmica de todos os aspectos da atividade humana.

Por se tratar se uma disciplina com amplo espectro, os domínios da ergo- 
nomia, foram subdivididos em três subdomínios de especialização, sendo eles: ergonomia física, ergonomia cognitiva e ergonomia organizacional.

Para este estudo, interessa a ergonomia física, "relacionada com as características da anatomia humana, antropometria, fisiologia e biomecânica em sua relação à atividade física." (MORAES, 2009)

De acordo com Pheasant apud Moraes (2009), se um objeto, um sistema ou um ambiente é projetado para o uso humano, então seu design deve se basear nas características físicas e mentais do seu usuário humano. Ergonomia é a ciência que objetiva adaptar o trabalho ao trabalhador e o produto ao usuário.

Sobre a antropometria, ciência que trata das medidas do corpo humano para determinar diferenças em indivíduos e grupos, de acordo com Panero (2011), para este trabalho, foram utilizads as referências relativas às medidas médias do corpo das crianças entre seis e nove anos, com o intuito de analisar a pertinência dos produtos selecionados em relação ao usuário.

Considerando-se o crescimento do corpo humano que ocorre de maneira que suas proporções variam de acordo com a estatura, recomenda-se que o mobiliário adotado seja compatível com as proporções da criança, que variam de acordo com a idade.

No que concerne as normas técnicas, a ABNT adota duas normas em relação ao mobiliário escolar: a NBR 14006 - Móveis escolares - Assentos e mesas para instituições educacionais - Classes e dimensões; e a NBR 14007 - Móveis escolares - Assentos e mesas para instituições educacionais - Requisitos. A NBR 14006 abrange as recomendações ergonômicas e antropométricas para mesas e cadeiras escolares. (2008)

A imagem e o quadro a seguir representam as recomendações contidas na norma NBR 14006. 

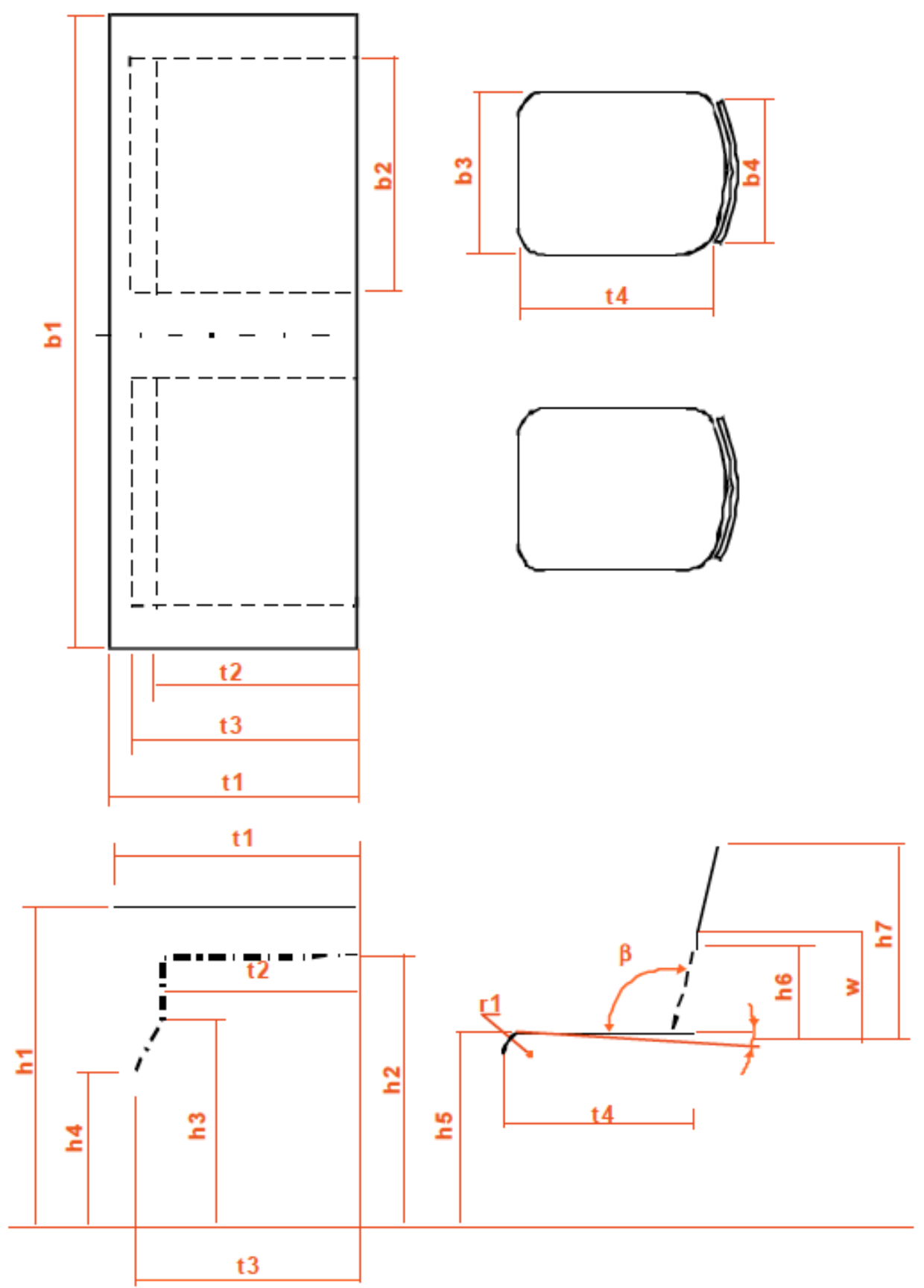

Figura 12 - Recomendações da NBR 14006 para cadeiras e mesas escolares

Fonte: Ministério da Educação - FUNDESCOLA 


\begin{tabular}{|c|c|c|c|c|c|c|c|c|}
\hline \multicolumn{2}{|r|}{ Número/cor } & $0 /$ branco & $1 /$ Iaranja & $2 /$ lilás & $3 /$ amarelo & $\begin{array}{c}4 / \\
\text { vermelho }\end{array}$ & $5 /$ verde & $6 /$ azul \\
\hline \multirow{2}{*}{$\begin{array}{r}\text { Classes/ } \\
\text { Estatura } \\
\text { Referencial }\end{array}$} & $\begin{array}{r}\text { Altura } \\
\text { corporal média }\end{array}$ & 900 & 1050 & 1200 & 1350 & 1500 & 1650 & 1800 \\
\hline & $\begin{array}{r}\text { Limites } \\
\text { inferior - superior }\end{array}$ & até 970 & 980 a 1120 & 1130 a & $\begin{array}{l}1280 \mathrm{a} \\
1420\end{array}$ & $\begin{array}{c}1430 \mathrm{a} \\
1570\end{array}$ & 1580 a 1720 & 1730 acim: \\
\hline \multicolumn{2}{|c|}{$\begin{array}{l}\text { h1 altura da superfície da mesa } \\
\text { (tolerância } \pm 10 \text { ) }\end{array}$} & 400 & 460 & 520 & 580 & 640 & 700 & 760 \\
\hline \multicolumn{2}{|c|}{$\begin{array}{l}\text { h2 altura mínima para o espaço } \\
\text { livre entre as pernas }\end{array}$} & & 350 & 410 & 470 & 530 & 590 & 650 \\
\hline \multicolumn{2}{|c|}{$\begin{array}{l}\text { h3 altura mínima para o espaço } \\
\text { do joelho }\end{array}$} & & 350 & 350 & 400 & 400 & 450 & 500 \\
\hline \multicolumn{2}{|c|}{$\begin{array}{l}\text { h4 altura mínima para o espaço } \\
\text { da tíbia }\end{array}$} & & 250 & 250 & 300 & 300 & 350 & 350 \\
\hline \multicolumn{2}{|c|}{$\begin{array}{l}\text { t1 largura mímina da superfície do } \\
\text { tampo }\end{array}$} & & 450 & $(500) 450$ & $(500) 450$ & (500) 450 & (500) 450 & $(500) 450$ \\
\hline \multicolumn{2}{|c|}{ b1 comprimento $\quad$ individual } & & 600 & 600 & $(700) 600$ & $(700) 600$ & $(700) 600$ & $(700) 600$ \\
\hline \multicolumn{2}{|c|}{ do tampo dupla } & & 1200 & 1200 & 1200 & $1200(1300)$ & $1200(1300)$ & $1200(1300)$ \\
\hline \multicolumn{2}{|c|}{$\begin{array}{l}\text { b2 largura mínima do espaço } \\
\text { livre do joelho }\end{array}$} & & 450 & 450 & 450 & $500(450)$ & $500(450)$ & $500(450)$ \\
\hline \multicolumn{2}{|c|}{$\begin{array}{l}\text { t2 profundidade mínima do } \\
\text { espaço livre do joelho }\end{array}$} & & 300 & 300 & 300 & $400(300)$ & $400(300)$ & $400(300)$ \\
\hline \multicolumn{2}{|c|}{$\begin{array}{l}\text { t3 profundidade mínima do } \\
\text { espaço livre da tíbia }\end{array}$} & & 260 & 290 & 330 & 360 & 380 & 400 \\
\hline \multicolumn{2}{|c|}{$\begin{array}{l}\text { h5 altura da superfície do assento } \\
\text { (tolerância } \pm 10 \text { ) }\end{array}$} & & 260 & 300 & 340 & 380 & 420 & 460 \\
\hline \multicolumn{2}{|c|}{$\begin{array}{l}\text { t4 profundidade do assento } \\
\text { funcional (tolerância }+10 \text { ) }\end{array}$} & & 260 & 290 & 330 & 360 & 380 & 400 \\
\hline \multicolumn{2}{|c|}{$\begin{array}{l}\text { b3 largura mínima da superfície } \\
\text { do assento }\end{array}$} & & 250 & 270 & 290 & 320 & 340 & 360 \\
\hline \multicolumn{2}{|c|}{$\begin{array}{l}\text { w altura do canto inferior do encosto em } \\
\text { relação à superfície do assento }\end{array}$} & & 160 & 170 & 190 & 200 & 210 & 220 \\
\hline \multicolumn{2}{|c|}{$\begin{array}{l}\text { h6 altura máxima da borda inferior } \\
\text { do encosto }\end{array}$} & & 120 & 130 & 150 & 160 & 170 & 190 \\
\hline \multirow{2}{*}{$\begin{array}{l}\text { h7 altura até a } \\
\text { borda superior } \\
\text { do encosto }\end{array}$} & mínima & & 210 & 250 & 280 & 310 & 330 & 360 \\
\hline & máxima & & 250 & 280 & 310 & 330 & 360 & 400 \\
\hline \multicolumn{2}{|c|}{$\begin{array}{l}\text { h8 altura mínima efetiva do } \\
\text { encosto }\end{array}$} & & 100 & 120 & 130 & 150 & 160 & 170 \\
\hline \multicolumn{2}{|c|}{$\begin{array}{l}\text { b4 largura mínima da superfície do } \\
\text { encosto }\end{array}$} & & 250 & 250 & 250 & 280 & 300 & 320 \\
\hline \multicolumn{2}{|c|}{ r1 raio da borda frontal do assento } & & 30 a 50 & 30 a 50 & 30 a 50 & 30 a 50 & 30 a 50 & 30 a 50 \\
\hline \multicolumn{2}{|c|}{ r2 raio mínimo do encosto } & & 300 & 300 & 300 & 300 & 300 & 300 \\
\hline \multicolumn{2}{|c|}{ d ângulo do assento } & & $0^{\circ}$ a $4^{\circ}$ & $0^{\circ}$ a $4^{\circ}$ & $0^{\circ}$ a $4^{\circ}$ & $0^{\circ}$ a $4^{\circ}$ & $0^{\circ}$ a $4^{\circ}$ & $0^{\circ}$ a $4^{\circ}$ \\
\hline \multicolumn{2}{|c|}{ ß inclinação do encosto } & & $95^{\circ}$ a $106^{\circ}$ & $95^{\circ}$ a $106^{\circ}$ & $95^{\circ}$ a $106^{\circ}$ & $95^{\circ}$ a $106^{\circ}$ & $95^{\circ}$ a $106^{\circ}$ & $95^{\circ}$ a $106^{\circ}$ \\
\hline
\end{tabular}

Quadro 1- Referências gráficas e quadro dimensional da NBR 14006 da ABNT (1997). As colunas realçadas em laranja são as que indicam dimensões características dos alunos em idade correspondente ao ensino fundamental.

Fonte: Ministério da Educação - FUNDESCOLA 
A partir destes documentos, foi possível tecer uma análise, ainda que superficial, acerca das mesas e cadeiras ofertadas pelas empresas selecionadas neste estudo, devido à falta de informações mais precisas sobre os produtos como, por exemplo, o ângulo do assento e informações pertinentes ao encosto das cadeiras. É válido ressaltar, porém, que não faz parte da proposta desta pesquisa investigar profundamente se o mobiliário ofertado pela indústria supre as necessidades ergonômicas e técnicas pertinentes ao desenvolvimento do produto ideal, apesar de reconhecer a importância crucial desta adequação para a saúde do usuário.

\subsubsection{Cadeiras:}

Foram compiladas, no total 20 cadeiras nos sites selecionados e, destas, 15 forneciam informações acerca de suas medidas, a maioria relacionada ao assento, como altura do assento ao chão, largura e profundidade.

Nas informações que constam nos quadros do Apêndice 2, em algumas cadeiras há informações como "para crianças entre 6 e 10 anos" ou "para o público infantil", extraídas do site com o intuito de verificar se, de fato, estes produtos estão preparados para atender a este público específico.

Conforme visto no quadro 1 - Recomendações da NBR 14006 para cadeiras e mesas escolares, é necessário que haja diversas informações referentes a cadeira para que se julgue apropriada ou não para o usuário, tais como ângulo do assento, inclinação do encosto da cadeira, altura da superfície do assento etc. Para cadeiras escolares, totalizam-se 12 informações pertinentes às medidas do produto, para julga-lo apropriado para o uso das crianças.

Considerando-se a falta das informações completas destas medidas, a análise foi feita baseando-se nas medidas referentes ao assento (altura do assento ao chão, largura e profundidade), cruzando-se estes dados com os da Imagem 12 (informações h5, b3 e t4 respectivamente) e com as medidas antropométricas das crianças por idade, obtidas em Panero e Zelnik (2011).

Desta forma, no Quadro 1 da NBR 14006 foram observadas as colunas referentes às alturas pertinentes às crianças entre seis e nove anos, que são as colunas denominadas "2/ lilás" (6 anos), "3/ amarelo" (7 e 8 anos) e "4/ vermelho" (9 anos), cruzando-se estes dados com os números pertinentes às medidas "h5" 
(altura da superfície do assento), "b3” (largura mínima da superfície do assento) e "t4" (profundidade do assento funcional) do Quadro 1 da NBR 14006, para compreender se, ao menos em relação a estas medidas, as cadeiras avaliadas estavam de acordo com a idade das crianças para as quais foram projetadas.

Os resultados obtidos foram que apenas as cadeiras de número 9, 65, 66 e 67 possuíam medidas que se adequavam a maioria das crianças na faixa etária de 7 e 8 anos (apesar de que todas as cadeiras, compiladas no Apêndice 2 deveriam servir teoricamente a crianças entre 6 e 10 anos, com exceção das cadeiras 8, 11 e 15 que servem para crianças entre 4 e 6 anos mas que, após a análise aqui realizada, não serviam para as de 6 anos, idade que interessa a esta pesquisa).

Todas as outras cadeiras, inclusive as citadas anteriormente, não estavam de acordo com as idades das crianças a que se destinavam. Em alguns casos, averiguou-se que a cadeira obteve algumas das medidas válidas porém não todas, como por exemplo é o caso das cadeiras 3 e 4 que, para crianças de 9 anos se adequam em relação à altura e à largura, porém não em relação à profundidade do assento; já a cadeira 14 seria adequada, em relação às medidas do assento, para crianças de 6 anos, exceto pela medida da altura do assento.

Acredita-se que esta disparidade entre o que as empresas afirmam (projetarem cadeiras ergonomicamente corretas para o público que atendem) e a realidade observada (produtos que em sua grande maioria não se adequam ao público em questão) é que as cadeiras são projetadas com o objetivo de atender ao maior número de crianças possível (por exemplo, crianças entre seis e dez anos), para compensar financeiramente às escolas e à compra das máquinas pelas empresas.

Desta forma, averiguasse que, apesar da grande diversidade de cadeiras ofertadas para o Ensino Infantil e para o Ensino Fundamental 1, estas acabam, em sua grande maioria, não sendo apropriadas a nenhuma das idades em questão, no que diz respeito às dimensões dos produtos, inclusive produzidas com materiais diversos, como pode ser observado na compilação dos produtos no Apêndice 2.

Notou-se também que as cadeiras cujas medidas dos assentos eram apropriadas, eram para crianças entre 7 e 8 anos, idades que estão na média entre os 6 e 10 anos, levando a entender que as cadeiras são projetadas para atender "ao meio do caminho" das idades em questão. 
É importante lembrar que todas as cadeiras analisadas são não-ajustáveis, fator que poderia solucionar os problemas das medidas, tornando possível moldar a cadeira em relação à criança em questão. Além disso, as medidas da crianças utilizadas por Panero e Zelnik (2011) são uma média e que, apesar de se tratar de 95\% de determinada população, exclui crianças com necessidades motoras especiais.

Esta análise das dimensões das cadeira foi importante porque, apesar de só utilizar 3 das 12 medidas relativas à ergonomia da cadeira escolar (de acordo com a NBR 14006), abre espaço para futuras análises acerca das ofertas deste produto, que faz parte da rotina de milhares de crianças no Brasil e que, conforme discorrido, necessita de melhores soluções para suprir as necessidades do público em questão.

\subsubsection{Mesas:}

As mesas compiladas nos sites das empresas totalizaram 60 produtos. Destes, 51 apresentaram as dimensões das alturas da superfície da mesa e da largura da superfície do tampo. Estas medidas são chamadas "h1" e " 1 1" no Quadro 1 da NBR 14006, que apresenta ainda outras 7 medidas necessárias para uma avaliação completa da viabilidade da mesa em relação ao público que atende.

Assim como foi feito com as cadeiras, foram observadas as colunas referentes às alturas pertinentes às crianças entre seis e nove anos, que são as colunas denominadas "2/ lilás" (6 anos), "3/ amarelo" (7 e 8 anos) e "4/vermelho" (9 anos), cruzando-se estes dados com os números pertinentes às medidas "h1" (altura da superfície da mesa) e "t1" (largura mínima da superfície do tampo) no Quadro 1 da NBR 14006, para compreender se, ao menos em relação a estas medidas, as mesas avaliadas estavam de acordo com a idade das crianças para as quais foram projetadas.

Após o cruzamento dos dados obtidos, chegou-se a conclusão que das 51 mesas:

- 8 modelos possuíam as medidas pertinentes apenas a crianças de 6 anos;

- 9 modelos possuíam a largura mínima da superfície da mesa adequadas para crianças de 6 anos, porém a altura da superfície da mesa não condizia com as me- 
didas médias da criança nesta idade;

- 17 mesas possuíam as medidas pertinentes apenas a crianças de 7 e 8 anos;

- 12 modelos possuíam a largura mínima da superfície da mesa adequadas para crianças de 7 e 8 anos, porém a altura da superfície da mesa não condizia com as medidas médias da criança nesta idade;

- 16 mesas possuíam as medidas pertinentes apenas a crianças de 9 anos;

- Nenhuma das mesas estava apropriada para crianças entre 6 e 9 anos ao mesmo tempo;

- As mesas 72, 73, 74, 75 e 76 serviram a crianças de 7,8 e 9 anos pois ofereciam versões com duas alturas da superfície da mesa distintas, para que o cliente escoIhesse a que melhor se adequa a idade da criança.

Averiguasse, portanto que, houve casos em que as empresas ofereciam diferentes alturas da superfície da mesa, possibilitando escolhas mais específicas por parte dos clientes. Porém, em grande parte dos casos, os produtos constavam como suprindo a necessidade das crianças do Ensino Fundamental 1 em geral.

Assim como com as cadeiras, foram compiladas mesas compostas por diversos materiais e em todos eles houve problemas em relação às medidas das mesas, não sendo, portanto, um problema que ocorra apenas com materiais específicos. Além disso, também é válido mencionar que acredita-se que esta disparidade das alturas da mesas dê-se também devido à necessidade do mercado de abranger o maior número possível de usuários de uma só vez, acarretando no prejuízo da saúda da criança, que faz uso destes produtos por, pelo menos, 20 horas semanais.

É válido lembrar que, apesar de só ter tido acesso a 2 ou 3 das 9 medidas utilizadas pela norma NBR 14006, já se pode inferir a necessidade de maiores estudos para projetos de mesas que atendam a uma maior parcela de crianças. 


\subsubsection{MATERIAIS E CORES OFERTADOS PELO MERCADO}

Os materiais ofertados pelas empresas selecionadas para os produtos analisados basicamente se dividem três grandes grupos: metais, plástico e derivados de madeira.

A cadeiras, em sua maioria, possuem estrutura em aço. O assento e o encosto encontraram-se em maior quantidade produzidas em plástico, como a resina plástica e o polipropileno. Algumas cadeiras possuíam apenas a indicação de terem base e assento em fórmica, porém acredita-se que seja apenas o revestimento neste material e a essência em algum derivados de madeira.

Em geral, nota-se que o aço é a estrutura concernente à grande maioria dos objetos avaliados. Os derivados de madeira, como o MDF, MDP e suas variações são mais utilizados nos tampos das mesas compiladas na pesquisa. As estantes e revisteiros quase se equiparam em quantidade no material pertinente a suas estruturas e prateleiras: aço e derivados de madeira, ou uma combinação dos mesmos.

O quadro a seguir retrata a quantidade de vezes, em unidade, que os materiais foram utilizados na composição dos objetos, de acordo com os sites da empresas pesquisadas. 


\begin{tabular}{|c|c|c|c|c|c|c|c|c|}
\hline \multirow{3}{*}{$\begin{array}{l}\text { material } \\
\text { aço }\end{array}$} & \multicolumn{2}{|c|}{ cadeiras } & \multicolumn{2}{|c|}{ mesas } & \multicolumn{2}{|c|}{ estantes e revisteiros } & \multicolumn{2}{|c|}{ outros } \\
\hline & estrutura & $\begin{array}{l}\text { assento } \\
\text { e encosto }\end{array}$ & estrutura & tampo & estrutura & prateleiras & estrutura & prateleiras \\
\hline & 8 & & 13 & & 12 & 11 & 2 & \\
\hline ferro & 1 & & & & & & & \\
\hline $\begin{array}{l}\text { metálica } \\
\text { sem especificação) }\end{array}$ & 1 & & 14 & & & & 2 & \\
\hline $\begin{array}{l}\text { esina plástica de } \\
\text { alto impacto }\end{array}$ & 1 & 3 & & 3 & & & 1 & \\
\hline polipropileno & & 5 & & & & & & \\
\hline $\begin{array}{l}\text { compensado } \\
\text { multilaminado }\end{array}$ & & 3 & & & & & & \\
\hline $\begin{array}{l}\text { compensado } \\
\text { revestido em fórmica }\end{array}$ & & & & 1 & & & & \\
\hline MDF & & & & 6 & & & & 2 \\
\hline $\begin{array}{l}\text { MDF revestido em } \\
\text { fórmica }\end{array}$ & & 2 & & 4 & 3 & 3 & & \\
\hline $\begin{array}{l}\text { MDF revestido em } \\
\text { aglomerado }\end{array}$ & & & & & 8 & 8 & & \\
\hline $\begin{array}{l}\text { chapa de aglomerado } \\
\text { texturizado }\end{array}$ & & & & & 1 & & & \\
\hline fórmica & & 5 & & 2 & & & & \\
\hline MDP & & & 1 & 1 & 2 & 2 & & 2 \\
\hline $\begin{array}{l}\text { MDP revestido em } \\
\text { fórmica }\end{array}$ & & & & 21 & & & & \\
\hline
\end{tabular}

Fonte: Autora 
Esta tabulação de dados teve por objetivo apontar os principais materiais utilizados para o projeto dos mobiliários escolares pesquisados e sua incidência. É interessante mencionar que algumas empresas, como a Desk, seguem um padrão de explorar o mesmo material em diferentes mobiliários, que seria o caso da resina plástica de alta densidade.

As outras empresas, no entanto, produzem mobiliários combinando diferentes materiais, como é o caso da Linearica, que disponibiliza a mesma cadeira com assentos e bases em derivados de madeira ou em plástico, por exemplo, acredita-se que visando atender ao maior número possível de públicos, que pode ter preferência por algum material (seja esta preferencia estética, relativa ao conforto ou ao financeiro).

Sabe-se que as empresas levam em consideração o melhor custo benefício no momento de decidir a escolha dos materiais envolvidos na concepção de seus produtos. Algumas alegam também priorizar a sustentabilidade e a qualidade dos materiais selecionados.

De acordo com o Ministério da Educação, por meio do documento FUNDESCOLA acerca dos mobiliários escolares, é fundamental que estes produtos cumpram determinados critérios para que sejam pertinentes ao uso. Um deles, acredita-se que foi cumprido por todas as cadeiras e mesas analisadas, que seria o uso de materiais mau-condutores de calor para todas as superfícies do móvel que têm contato com o corpo. Supõem-se que as estantes e expositores de livros apareçam com suas prateleiras e estruturas em materiais metálicos pelo breve contato que o usuário, ao menos a criança, tem com estes objetos.

Conclui-se que o uso da fórmica como revestimento mais utilizado na composição dos tampos de mesa se deu por este material trazer características importantes para o uso cotidiano destes produtos pelos usuários em questão, tais como: resistência a manchas, resistência a impactos, antialérgicos, de fácil limpeza e diversidade de cores. No entanto, o tipo de acabamento da fórmica pode levar à preocupação com a capacidade visual do usuário, a depender da intensidade do brilho desta fórmica, devendo-se, portanto, levar este critério em questão na escolha do produto.

O formato dos tampos das mesas também deve ser mencionado pois no- 
tasse que, apesar dos formatos se repetirem em diferentes empresas, mudando apenas cores e materiais, é interessante que já exista uma quantidade considerável de formatos de tampos de mesa, que permitem diferentes configurações dos mobiliários, possibilitando diversas atividades ou número de participantes, com o mesmo mobiliário. Este tipo de solução projetual interessa para aumentar o potencial de socialização da criança e para expandir as capacidades dos possíveis cenários em um mesmo ambiente.

No que diz respeito à maciez dos assentos das cadeiras, o mesmo documento da FUNDESCOLA prevê o uso de assentos duros e rígidos para as crianças, critério este cumprido por todas as cadeiras analisadas. No entanto, Kowaltowski (2011) traz, em um de seus parâmetros de projeto para escolas, o mobiliário macio para sentar, alegando que, devido à maior queixa dos alunos nas avaliações pós-ocupações nas escolas, que estes consideram as cadeiras muito duras. Assim, a autora defende o uso de estofado nas cadeiras escolares.

Sobre as cores oferecidas pelas empresas para os produtos analisados, percebesse, ao analisar o Quadro 3 que os derivados de plástico e a fórmica oferecem vasta gama de possibilidades de cores, como é possível observar no quadro a seguir: 


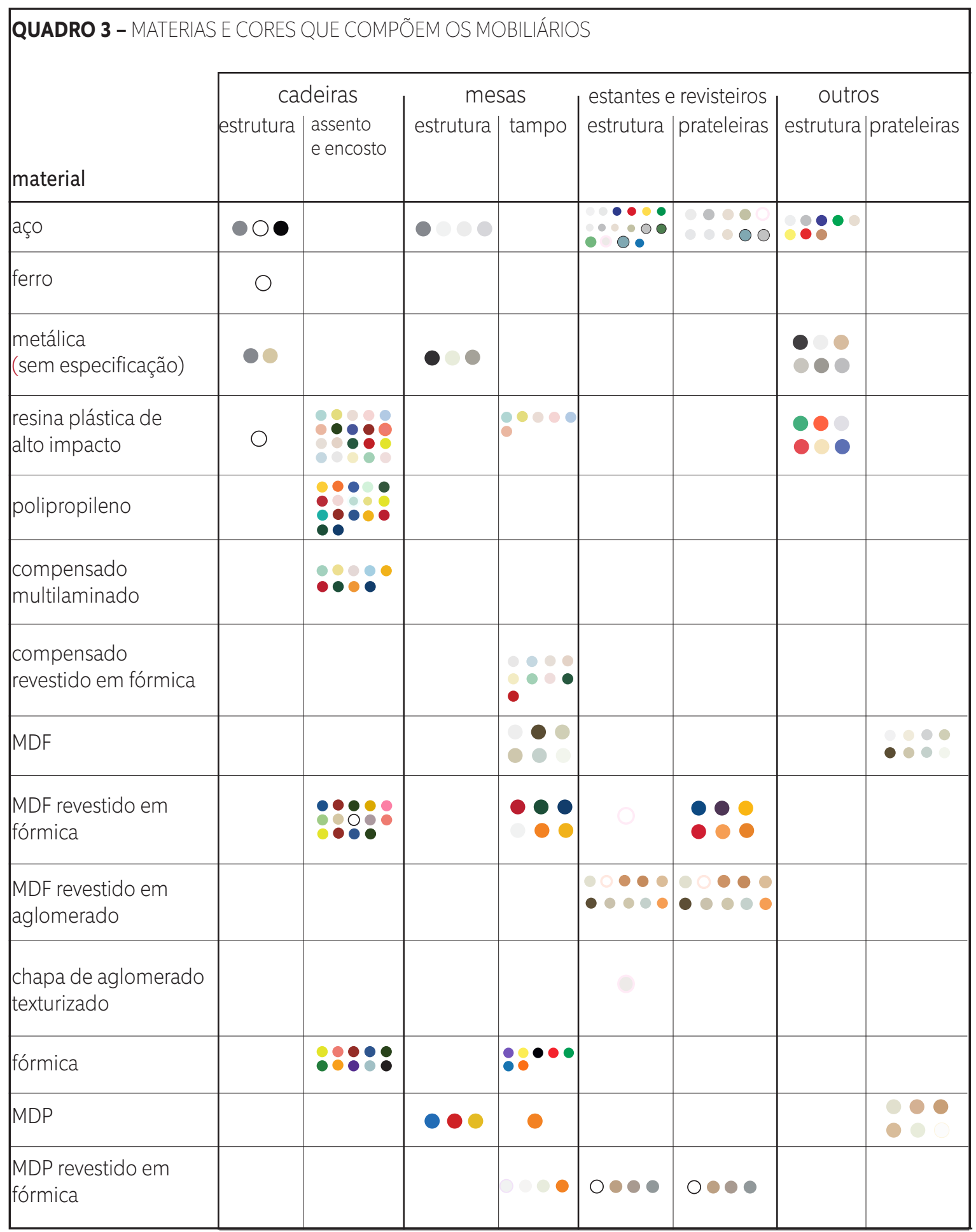

Fonte: Autora

Em relação à estrutura dos mobiliários, para mesas e cadeiras prevalecem cores sóbrias, como branco, tons de cinza e preto, independente da matéria-prima utilizada. Acredita-se que as empresas investem na diversidade de cores vivas, fortes e lúdicas nos tampos da mesas e nos assentos e encostos da cadeiras por 
serem as partes mais visíveis dos produtos, dando mais destaque às cores e proporcionando produtos mais lúdicos.

De acordo com o documento da FUNDESCOLA, todas as superfícies de mesas devem ser neutras. Neste sentido, são poucas as empresas das selecionadas para este estudo que atendem a este requisito, como é o caso da Biccateca e da Omega Design, que oferecem assentos e encostos em cores claras e neutras. As mesas oferecidas pela Linearica possuem tampo branco e estrutura em tom cinza, dando a elas características positivas em relação às exigências do Ministério da Educação.

Compreende-se a lógica do mercado em oferecer mobiliários voltados para o público infantil em cores lúdicas, vibrantes e "alegres" e não pretende-se aqui entrar em méritos de estudos psicológicos e dos escopos da física nesta pesquisa que comprovem a necessidade do uso de cores neutras nas superfícies das mesas e cadeiras. O que se gostaria de apontar é a possibilidade de se atender às demandas do Ministério da Educação utilizando-se cores neutras nas superfícies das mesas e oferecer ambientes agradáveis e lúdicos às crianças. Esta afirmação é feita após observar-se a aplicação destes móveis em espaços escolares infantis, conforme as imagens a seguir, retiradas dos sites das empresas:

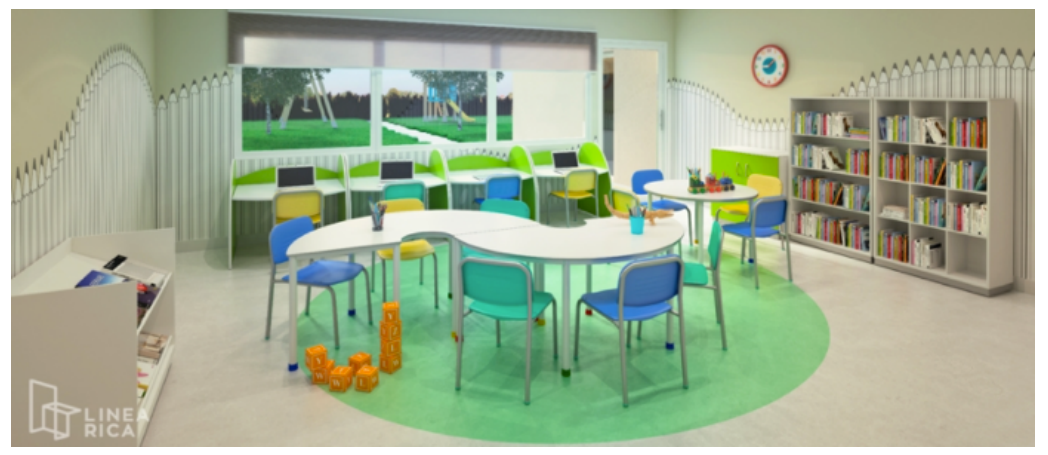

Figura 13 - Possível ambiente de uma biblioteca infantil. Fonte: site da empresa Linearica. Disponível em: < http://linearica.com.br/> Último acesso em: 15 de janeiro de 2017

Este tópico acerca dos mobiliários oferecidos pela indústria teve como objetivo situar o leitor sobre as possibilidades de mobiliários para o público infantil em questão, no intuito de apresentar o que existe no mercado e o que pôde ser encontrado nos estudos de caso do Capítulo 4 desta dissertação. 


\subsection{ANÁLISE DE BIBLIOTECAS INFANTIS}

Foram selecionados três espaços voltados para o público infantil relativos à leitura e ao lazer de diversas partes do mundo, com a finalidade de investigar a organização espacial e as características destes ambientes considerados referência de projeto em arquitetura ou design.

Considerando-se que os dados obtidos tiveram origem nas informações cedidas pelos sites das instituições selecionadas, antecipa-se aqui a superficialidade da análise, considerando-se que aspectos importantes para se obter uma completa avaliação do ambiente devem ser colhidos com ferramentas mais apropriadas, como em visita de campo e entrevista com arquitetos e designers responsáveis pelo projeto. Neste sentido, ainda que as análises dos ambientes em questão possam ser consideradas rasas, decidiu-se por levá-las adiante, por acreditar que, ainda assim, observar a organização destes espaços e os equipamentos oferecidos para seus usuários venha a trazer pistas acerca de possibilidades interessantes para as bibliotecas infantis brasileiras.

Por este motivo, deixou-se de investigar espaços de bibliotecas paulistanas que já possuem soluções interessantes de desenvolvimento de mobiliários e de organização de seus espaços, como a Biblioteca de São Paulo e a Biblioteca do Parque Villa Lobos pois, apesar de serem referência em bibliotecas públicas, nos aspectos buscados por esta pesquisa, a pesquisadora, no entanto, optou por focar em locais mundialmente reconhecidos, quer por questões voltadas para a relação do mobiliário com o espaço ou por terem conquistado prêmios na área do design de interiores.

\subsubsection{CRITÉRIOS PARA AS ANÁLISES}

Conforme explicado no tópico anterior, não foram feitas visitas presenciais aos espaços escolhidos, nem obteve-se acesso às medidas espaciais ou materiais dos equipamentos que os compõem. Desta forma, as análise foram feitas baseando-se em parâmetros que, de acordo com Kowaltowski (2011), podem enriquecer a experiência humana nos ambientes de ensino. Sabe-se que a autora escreve debruçando suas análise em ambientes escolares. No entanto, considerando-se 
que, em termos de análise de ambientes projetados para crianças, a autora é referência, optou-se por fazer uso destes parâmetros para a análise da bibliotecas infantis.

Kowaltowski (2011) apresenta a aplicação do método patterns para o projeto escolar "por um reenquadramento das discussões entre arquitetura e educação, com base em 25 parâmetros”. Tendo como preceitos os objetivos desta pesquisa e também os dados limitados para as análise dos espaços, os patterns que serão avaliados são os seguintes:

\section{-Parâmetro de projeto 1}

"Sugere a importância da análise sobre o tipo de ambiente considerado adequado para uma sala de aula." A autora apresenta onze necessidades básicas de salas de aula, das quais foram selecionadas as que podem se relacionar às necessidades do ambiente da biblioteca infantil, levando em consideração aspectos que interessam à Infoeducação e à autonomia e apropriação do espaço esperados para o usuário da biblioteca infantil:

- Os alunos podem se movimentar livremente;

- Os alunos podem desenvolver diversas atividades com equipamentos e objetos;

- Os layouts para diferentes tipos de atividades: individuais, em duplas, pequenos grupos, a classe toda;

- Os alunos conseguem ter um senso de identidade e de pertencimento ao grupo.

\section{-Parâmetro de projeto 9}

"Deve transmitir a ideia de que educação e aprendizagem são visíveis e celebradas na escola." Deve considerar:

- Uma área administrativa com acesso visual a áreas de socialização e estudo individual ou em grupo;

- Uma área administrativa aberta, em espaço convidativo;

- corredores com luz natural; áreas de estudo com aberturas para os corredores, permitindo a supervisão natural desses espaços.

Neste sentido, buscou-se adaptar este parâmetro para a relação entre o posicionamento da estação de trabalho do bibliotecário e dos funcionários da biblioteca e do ambiente para a criança pois, em bibliotecas mais tradicionais, o 
funcionário se encontra atrás de um balcão imponente que simboliza o limite do espaço reservado para a criança.

\section{- Parâmetro de projeto 11}

"A tecnologia faz parte de nossa vida e não pode ser ignorada no ambiente escolar." Em relação a este parâmetro, buscou-se observar se havia, nos espaços, equipamentos eletrônicos para uso das crianças.

\section{- Parâmetro de projeto 13}

Refere-se ao mobiliário para sentar, onde a autora defende o uso de assentos confortáveis e macios, devido à grande quantidade de reclamações por parte dos alunos da dureza dos assentos escolares.

\section{-Parâmetro de projeto 14}

Explica a necessidade de generosidade do espaço; paredes suficientes para permitir a colocação de bancadas, estantes, mesas etc; móveis como rodízios, dentre outros aspectos relativos a espaços considerados flexíveis.

\section{- Parâmetro de projeto 20}

Diz respeito à ventilação natural, que cria ambientes mais saudáveis devido à troca de ar.

\section{- Parâmetro de projeto 23}

Ressalta a importância da linguagem arquitetônica escolhida para o projeto em questão, que deve "expressar os valores da escola e da comunidade".

\subsubsection{ANÁLISE DOS AMBIENTES}

Serão apresentadas e analisadas a seguir, três bibliotecas que se destacam mundialmente, ganhando prêmios referentes a questões ligadas à arquitetura ou design. 


\subsubsection{Biblioteca Niños CONARTE - México}

O CONARTE (Conselho para a Cultura e as Artes de Nuevo León) é um órgão público do governo do estado de Nuevo León que visa, dentre outros objetivos, promover e incentivar a expressão artística e a cultura popular do estado.

Dentre os diversos espaços oferecidos pelo CONARTE, destaca-se a Biblioteca Niños CONARTE, inaugurada em junho de 2013, antes uma antiga fábrica de rodas que foi restaurada e adaptada para se tornar este espaço dedicado ao público infantil. De acordo com o site do local, "é um espaço lúdico e de aprendizagem para as crianças, pais, a comunidade educativa e formação da cultura infantil. Um lugar dedicado à inclusão de pessoas com deficiência, promoção da leitura e da arte-educação."

O espaço é aberto ao público de terça a domingo, das 9:00 às 19:00, com entrada gratuita. De acordo com informações obtidas no site do órgão, para visitar o espaço destinado à leitura é necessário levar meias.

A sala de leitura conta com um acervo de quase 5 mil livros de literatura infantil para diferentes faixas etárias.

Compreende-se que se trata de um espaço voltado para a socialização, leitura e outras atividades lúdicas, destinado ao público infantil e seus responsáveis, com projeto do ambiente que, de acordo com o site, busca atender também ao público com algum tipo de deficiência.

As imagens a seguir foram extraídas de sites com notícias sobre a Niños CONARTE e mostram partes dos ambientes que compõem o espaço. A pesquisadora buscou apontar nas imagens a existência ou não de alguns dos Parâmetros de projeto indicados por Kowaltowski (2011) para o projeto escolar, sendo estes adaptados para os ambientes analisados neste capítulo. 


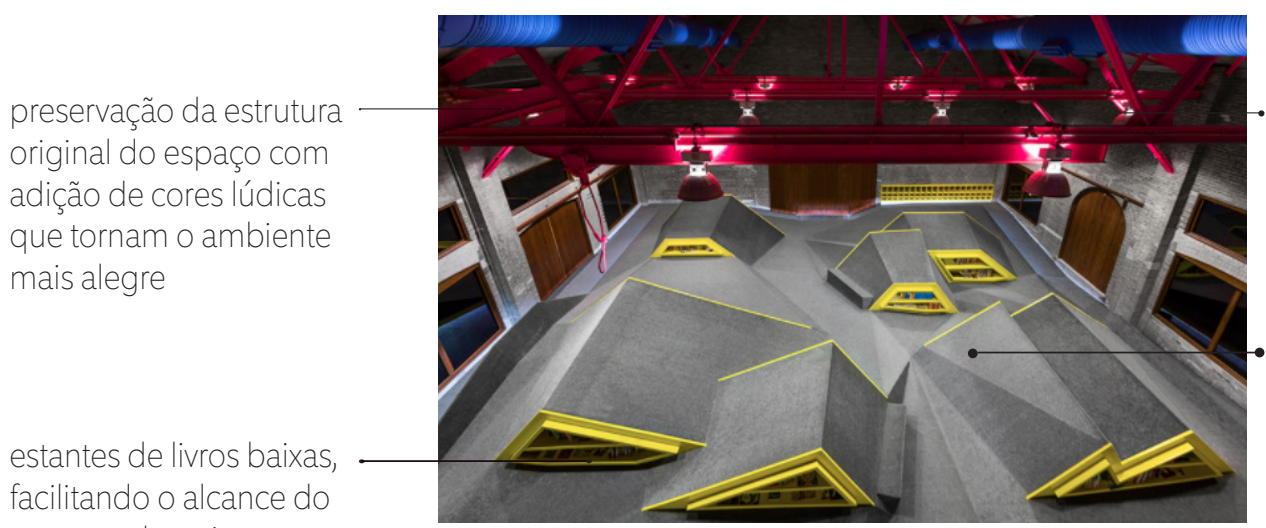

acervo pelas crianças. a

cor amarela em contraste com o cinza dá destaque ao mobiliário e torna o ambiente mais vivo
Figura 14 - Ambiente de leitura da Biblioteca Niños CONARTE

Disponível em: <http://www.conarte.org.mx/NINOS>

Último acesso em: 20 de janeiro de 2017 Fonte: site da CONTARTE. iluminação em

spots direcionáveis

que possibilitam

diferentes posições

material semelhante a um carpete, recobrindo as estantes. serve como local para leitura e outras atividades. para acessálo é preciso usar meias

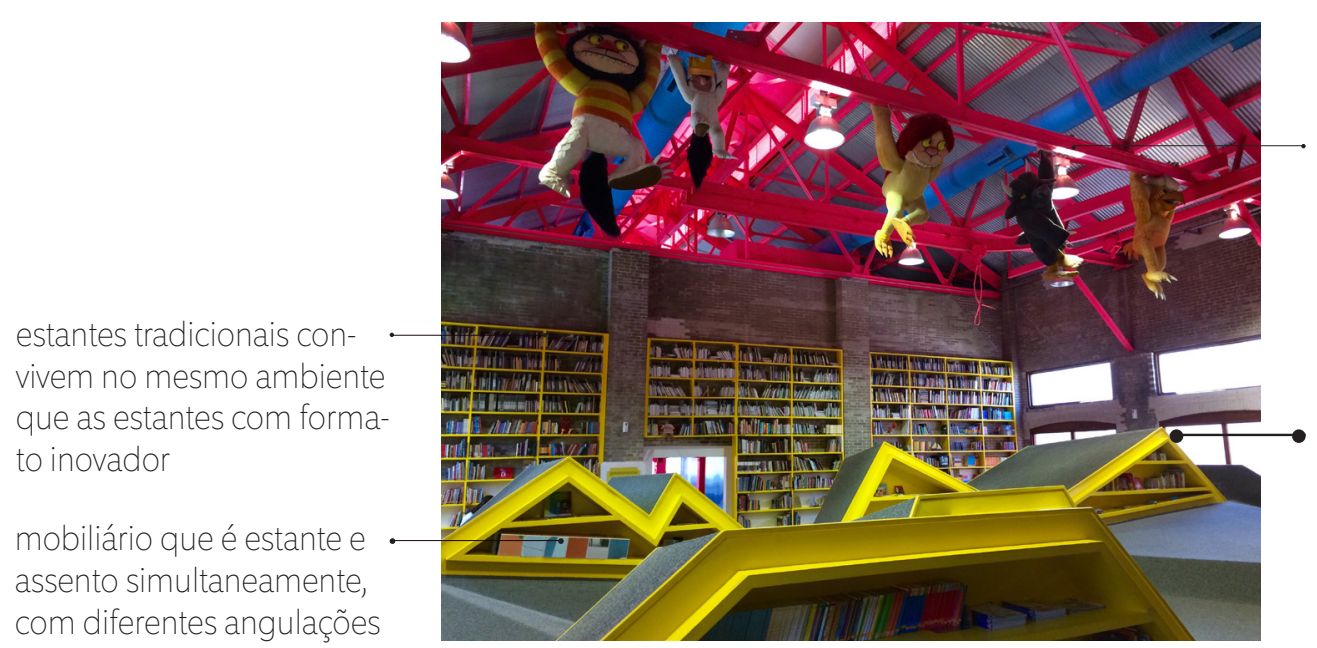

Figura 15 - Ambiente de leitura da Biblioteca Niños CONARTE Fonte: site da CONTARTE.

Disponível em: <http://www.conarte.org.mx/NINOS> Último acesso em: 20 de janeiro de 2017

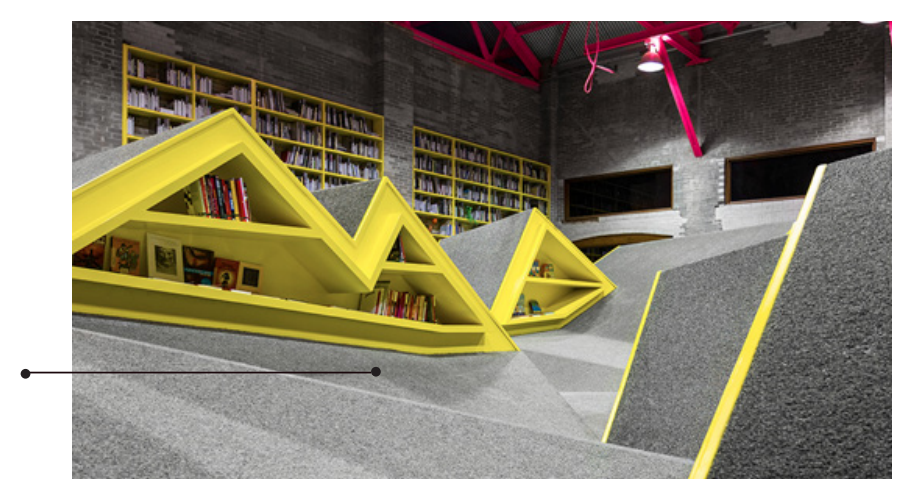

Figura 16 - Ambiente de leitura da Biblioteca Niños CONARTE Fonte: site da CONTARTE.

Disponível em: <http://www.conarte.org.mx/NINOS>

Último acesso em: 20 de janeiro de 2017 a depender de onde o usuário se encontre, terá a impressão de estar em um local com múltiplos esconderijos, devido ao desnivelamento do piso versatilidade da estrutura que permite adaptar cenários e decorar o ambiente esporadicamente

combinação de iluminação natural e artifical no mesmo ambiente 


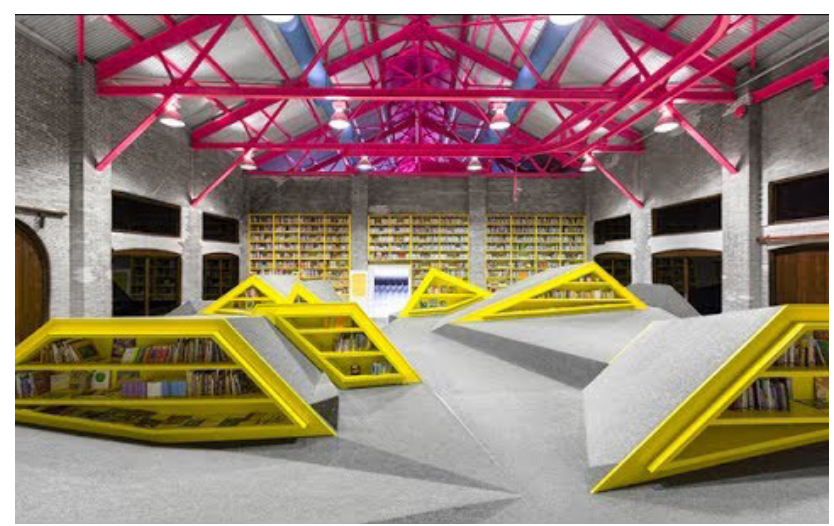

Figura 17 - Ambiente de leitura da Biblioteca Niños CONARTE Fonte: site da CONTARTE.

Disponível em: <http://www.conarte.org.mx/NINOS>

Último acesso em: 20 de janeiro de 2017
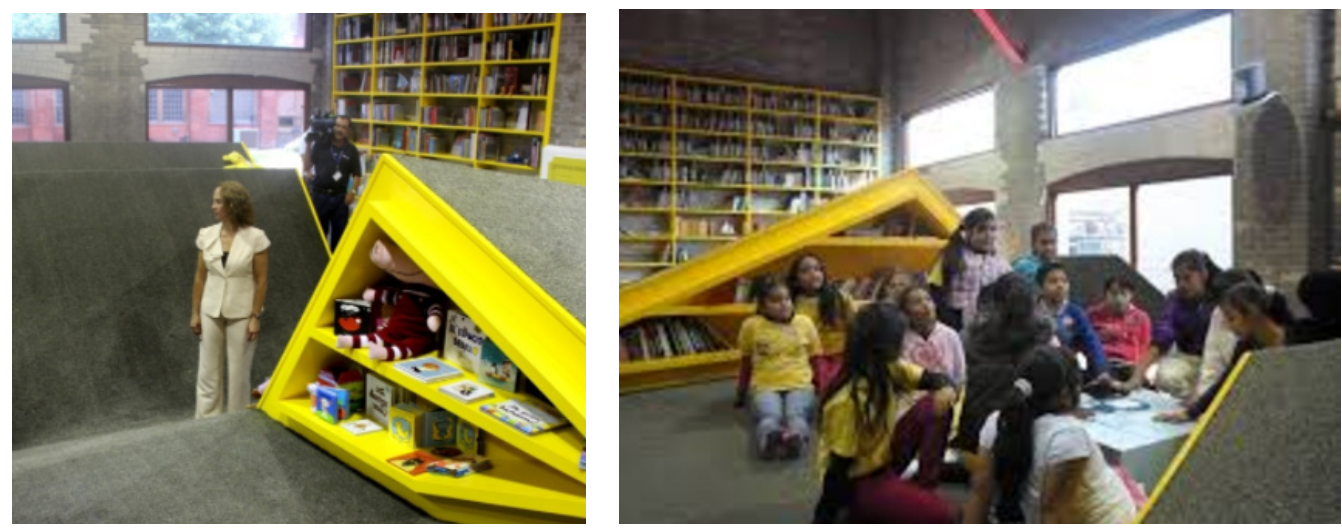

Figuras 18 (esquerda) e 19 (direita) - Ambiente de leitura da Biblioteca Niños CONARTE Fonte: site da CONTARTE.

Disponível em: <http://www.conarte.org.mx/NINOS>

Último acesso em: 20 de janeiro de 2017
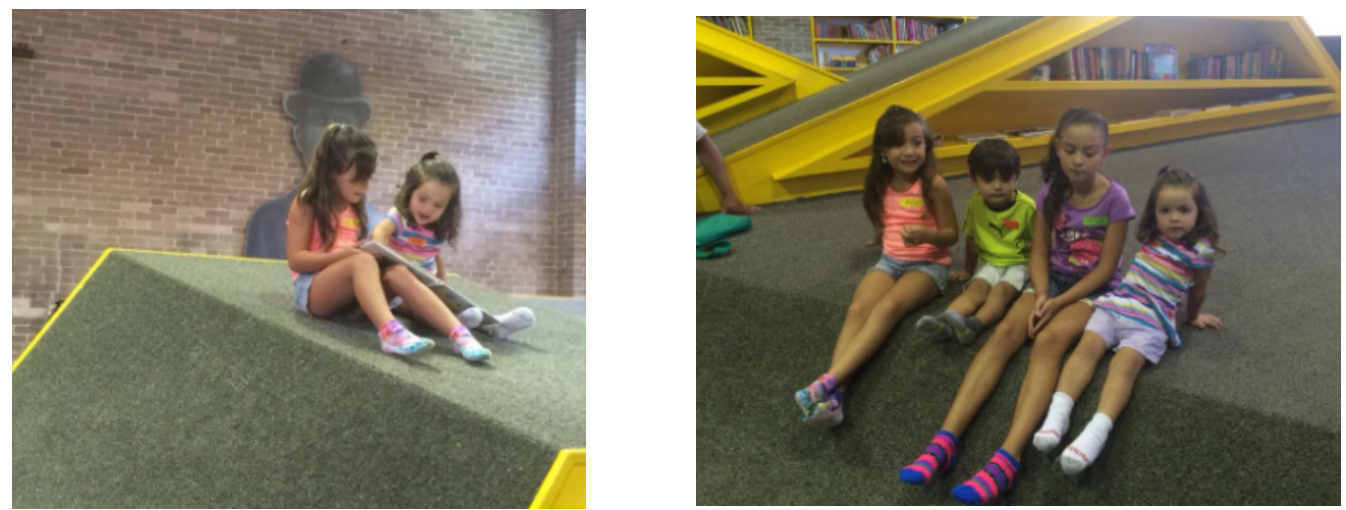

Figuras 20 (esquerda) e 21(direita) - Ambiente de leitura da Biblioteca Niños CONARTE Fonte: site da CONTARTE.

Disponível em: <http://www.conarte.org.mx/NINOS>

Último acesso em: 20 de janeiro de 2017 

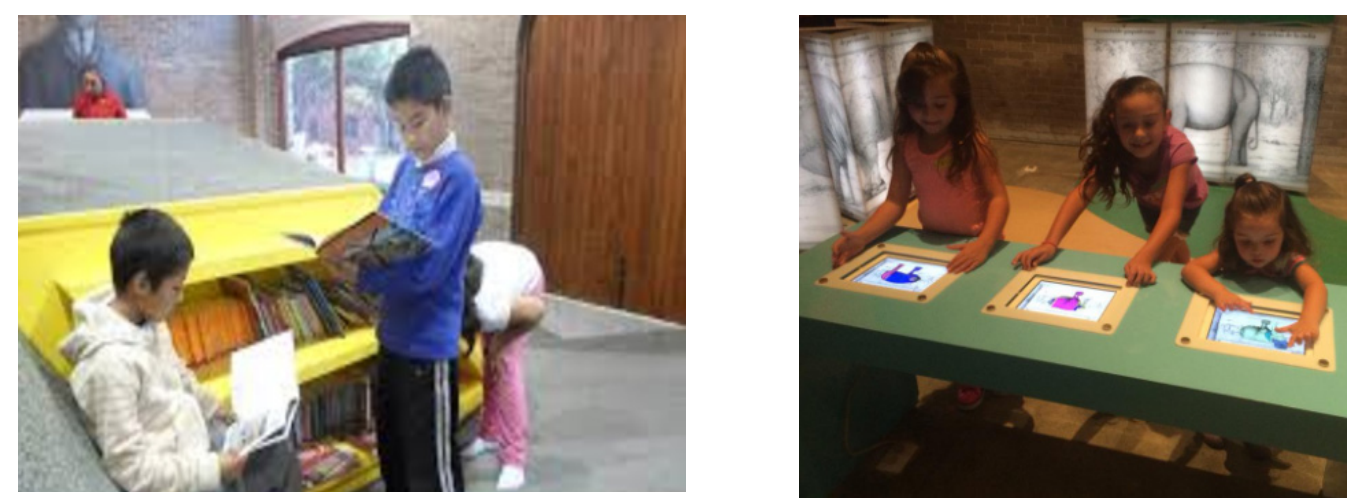

Figuras 22 (esquerda) e 23 (direita) - Ambiente de leitura da Biblioteca Niños CONARTE Fonte: site da CONTARTE.

Disponível em: <http://www.conarte.org.mx/NINOS>

Último acesso em: 20 de janeiro de 2017

As imagens acima mostram crianças fazendo uso do espaço de leitura (com exceção da Figura 23) tanto em atividades direcionadas quanto livres. Observa-se que o mobiliário e as estantes permitem diversas posições para sentar, deitar ou se escorar no mobiliário.

A Figura 23 mostra crianças fazendo uso de equipamentos eletrônicos, aparentemente tablets, fixados na mesa, mostrando que a biblioteca faz uso de equipamentos eletrônicos.

A visão frontal do ambiente de leitura, na Figura 17, mostra que o espaço é generoso e possibilita que o usuário se movimente livre, além de oferecer possibilidades do uso da imaginação pelas crianças, para o brincar.

A Figura 18 mostra a proporção do mobiliário em relação ao adulto: aparenta caber confortavelmente no espaço. observa-se também a presença de brinquedos nas prateleiras, significando que o espaço é uso para diversas atividades.

O quadro a seguir expõe de maneira sintetizada os aspectos referentes aos parâmetros selecionados para análise dos ambientes em relação à Biblioteca Niños CONARTE: 
PARÂMETRO 1 - observou-se nas imagens que é possível realizar-se diversas atividades, apesar da impossibilidade de movimentação do mobiliário presente. além disso, o espaço amplo permite que as crianças explorem o brincar, a leitura e outra atividades lúdicas.

PARÂMETRO 9 - não foi possível observar nas fotografias como se dá a delimitação da área voltada para os bibliotecários e outros funcionários. no que diz respeito à iluminação natural, observou-se que está diretamente presente no espaço, com a presença de amplas janelas.

PARÂMETRO 11 - em relação ao uso de tecnologia no local, houve apenas uma imagem que mostrava crianças interagindo com equipamentos eletrônicos (ao que tudo indica tablets). estes aparentavam estar atrelados a uma superfície, acredita-se que por motivos de segurança, mas que pode dificultar a interação da criança com o produto, caso a hipótese esteja correta.

PARÂMETRO 13 - de acordo com as imagens disponibilizadas, notou-se que o único assento para o usuário é o piso revestido com um material semelhante a um carpete. considerando-se que as análises são feitas por meio de fotografias, nnao se pode afirmar se os assentos são confortáveis.

PARÂMETRO 14 - o espaço se mostra grande o suficiente para receber uma quantidade considerável de crianças ao mesmo tempo

PARÂMETRO 20 - apesar da existência de janelas no local, não há informações de como é feita a manutenção da temperatura no local, se esta é natural ou se o local faz uso de equipamentos como ar-condicionado ou ventilador.

PARÂMETRO 23 - o ambiente é inovador na disposição e no formato de seu mobiliário, no fato da multipluralidade de usos para o mesmo objeto, que é estante e assento ao mesmo tempo. o desnível do piso torna o espaço uma possibilidade de aventura para crianças menores. além disso, o uso de poucas cores, porém fortes e vibrantes dão ao local um aspecto lúdico. o fato de terem preservado as estruturas metálicas do teto, como os tubos de ventilação e dado a eles cores para ajudar a ambientar o espaço foi uma ideia muito interessante para preservar a memória do local e ao mesmo tempo inserí-lo na contemporaneidade.

Fonte: autora

Considera-se, portanto, que, em relação aos parâmetros observados, esta biblioteca pode ser considerada inovadora em aspectos de projeto de mobiliário, que se unem ao espaço tornando-se um único equipamento. A multiplicidade dos potenciais das estantes que são, ao mesmo, estante e assento é um dos fatores mais memoráveis em relação a esta biblioteca. É válido lembrar que para acessar este espaço o usuário deve estar utilizando um par de meias, o que colabora para a manutenção do suposto carpete e diminui as chances de proliferação de doenças devido ao contato da criança com o carpete, pois muitas podem se deitar com o rosto ou colocar a boca no piso e assim adoecer. 


\subsubsection{Biblioteca Pública de Hjorring - Dinamarca}

A construção desta biblioteca data de 2008 e, apesar de não ser uma biblioteca voltada apenas para o público infantil, escolheu-se analisá-la devido a sua importância para ambientes semelhantes pois, após sua inauguração, seu projeto serviu de inspiração para muitas outras bibliotecas, livrarias e até ambientes escolares no mundo inteiro. Esta biblioteca ganhou prêmios mundiais devido a seu projeto inovador como, por exemplo, o Library Interior Design Award, categoria do International Interior Design Association que anualmente premia ambientes considerados inovadores ou que se destacam em suas áreas.

Um fator interessante sobre esta biblioteca é que ela se localiza dentro de um shopping center na Dinamarca e, de acordo com seu site, o custo total do projeto girou em torno de 1.750 .000 euros.

Devido a um aspecto de projeto que faz parte da essência da biblioteca, foram observadas também algumas características referentes aos ambientes voltados para adultos.

As imagens a seguir mostram partes dos ambientes que compõem a biblioteca. A pesquisadora buscou apontar nas imagens a existência ou não de alguns dos Parâmetros de projeto indicados por Kowaltowski (2011) para o projeto escolar, sendo estes adaptados para os ambientes analisados neste capítulo.

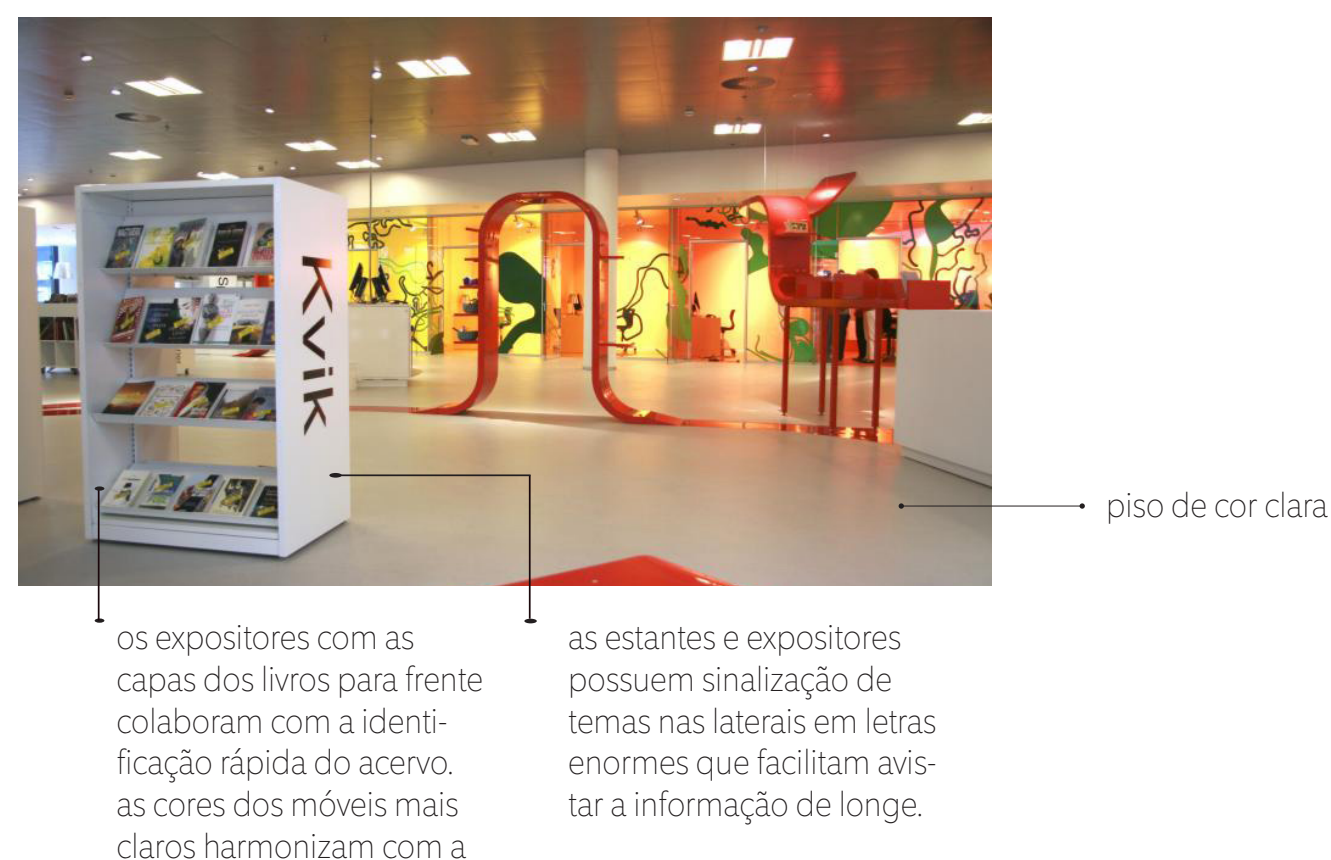
grande faixa larania local. 


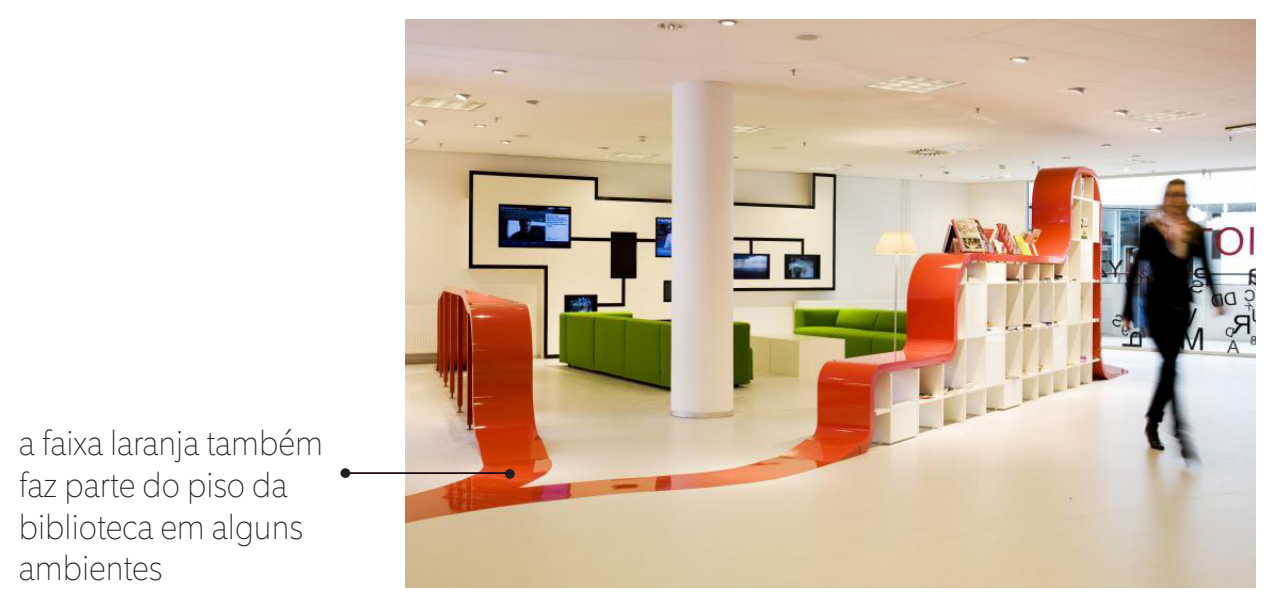

Figura 25- Biblioteca de Hjorring

Fonte: site Library Buildings

Disponívelem: < http://www.librarybuildings.info/denmark/hjorring-library-metropol >

Último acesso em: 19 de janeiro de 2017

O ambiente acima também apresenta mobiliários com tons fortes, como é o caso do sofá verde. esta inserção de cores mais vivas em harmonia com os ambientes predominantemente neutros torna o espaço mais lúdico, ainda que para adultos.

iluminação em spots direcionáveis que possibilitam diferentes posições e luminárias fixas no teto a árvore de leitura é um objeto ao mesmo tempo temático e com cor vibrante, porém que dialoga perfeitamente com o ambiente, que não possui um tema oficial, apenas uma paleta de cores e harmonia entre seus mobiliários

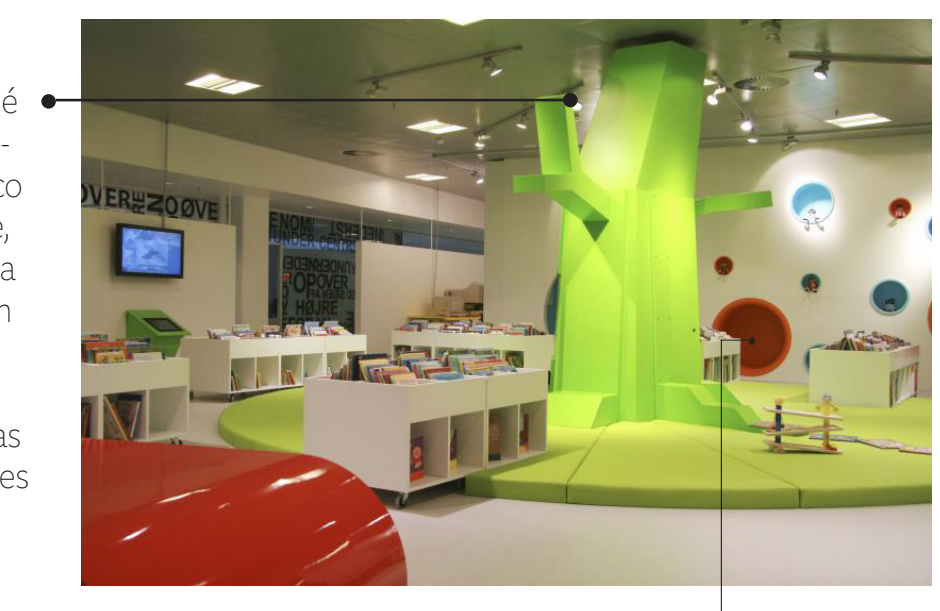

apesar de não saber para quê serve este equipamento, observou-se que trata-se de algum eletrônico no tótem, talvez para pesquisa do acervo. vê-se também uma televisão, mostrando a tecnologia inserida no ambiente os expositores aparentam serem projetados para ser usado por crianças. a forma como o acervo é organizado permite fácil manipulação dos livros e fácil modificação do arrano espacial o espaço ao redor da árvore é constituído de material aparentemente confortável e permite diversas ações como a leitura e brincadeiras, por exemplo. os círculos de leitura na parede são acolchoados e permitem que as crianças deitem neles para ler ou descansar.

Figura 26- Biblioteca de Hjorring Fonte: site Library Buildings Disponívelem: < http://www.librarybuildings.info/denmark/hjorring-library-metropol $>$

Último acesso em: 19 de janeiro de 2017 
o uso de cores fortes e vibrantes nos mobiliários torna o ambiente lúdico, mesmo sem grafismos ou temas

a presença de uma pilha de almofadões dá às crianças a possibilidade de ler, brincar, descansar etc. o objeto aparenta ter revestimento em material de alta durabilidade de ser confortável

observa-se que os ambientes possuem equipamentos e mobiliários de diferentes composições materiais que dialogam entre si

o mobiliário verde que circunda os almofadões azuis dão uma ideia de ilha para o local onde a criança está deitada. ao mesmo tempo, o móvel verde serve como banco para os usuários.

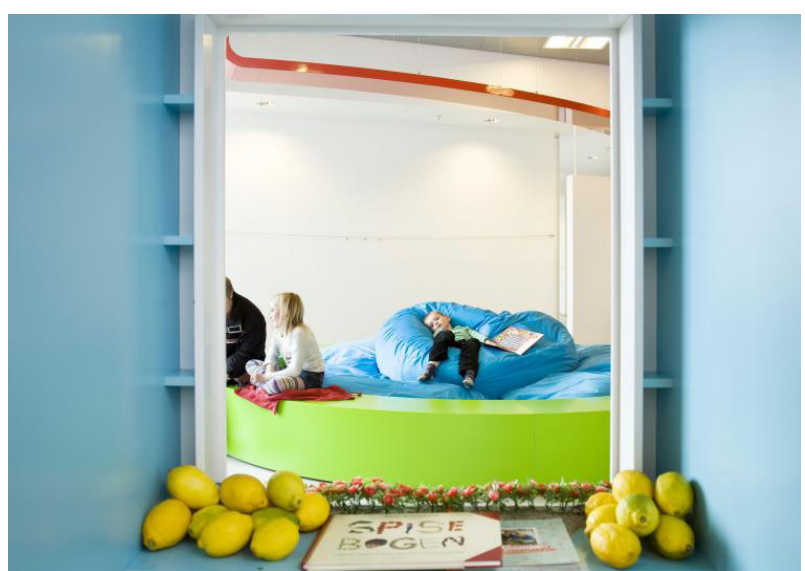

Figura 27- Biblioteca de Hjorring Fonte: site Library Buildings

Disponível em: <http://www.librarybuildings.info/denmark/hjorring-library-metropol >

Último acesso em: 19 de janeiro de 2017

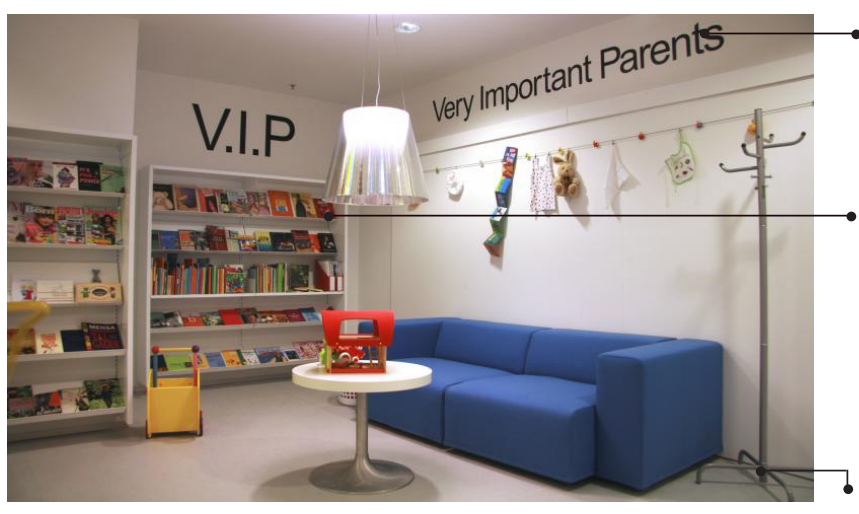

Figura 28- Biblioteca de Hjorring

Fonte: site Library Buildings

Disponível em: <http://www.librarybuildings.info/denmark/hjorring-library-metropol >

Último acesso em: 19 de janeiro de 2017
Sinalização que se traduz como "Pais Muito Importantes" espaço infantil com sensibilização para o papel dos pais, que podem ficar esperando no sofá por seus filhos, por exemplo.

estantes com prateleiras expositoras da capa dos livros reforçam a autonomia das crianças; notou-se que todos os mobiliários expositores que puderam ser vistos são na cor branca, o que possibilita investir em outras coras nos outros equipamentos e mobiliários sem cansar a vista do usuário.

presença de um cabideiro no local provalvemente para que os pais possam deixar suas bolsas ou acessórios

brinquedos no espaço da biblioteca reforçam o pensamento que o espaço é voltado para diversas atividades lúdicas, não apenas a leitura. 


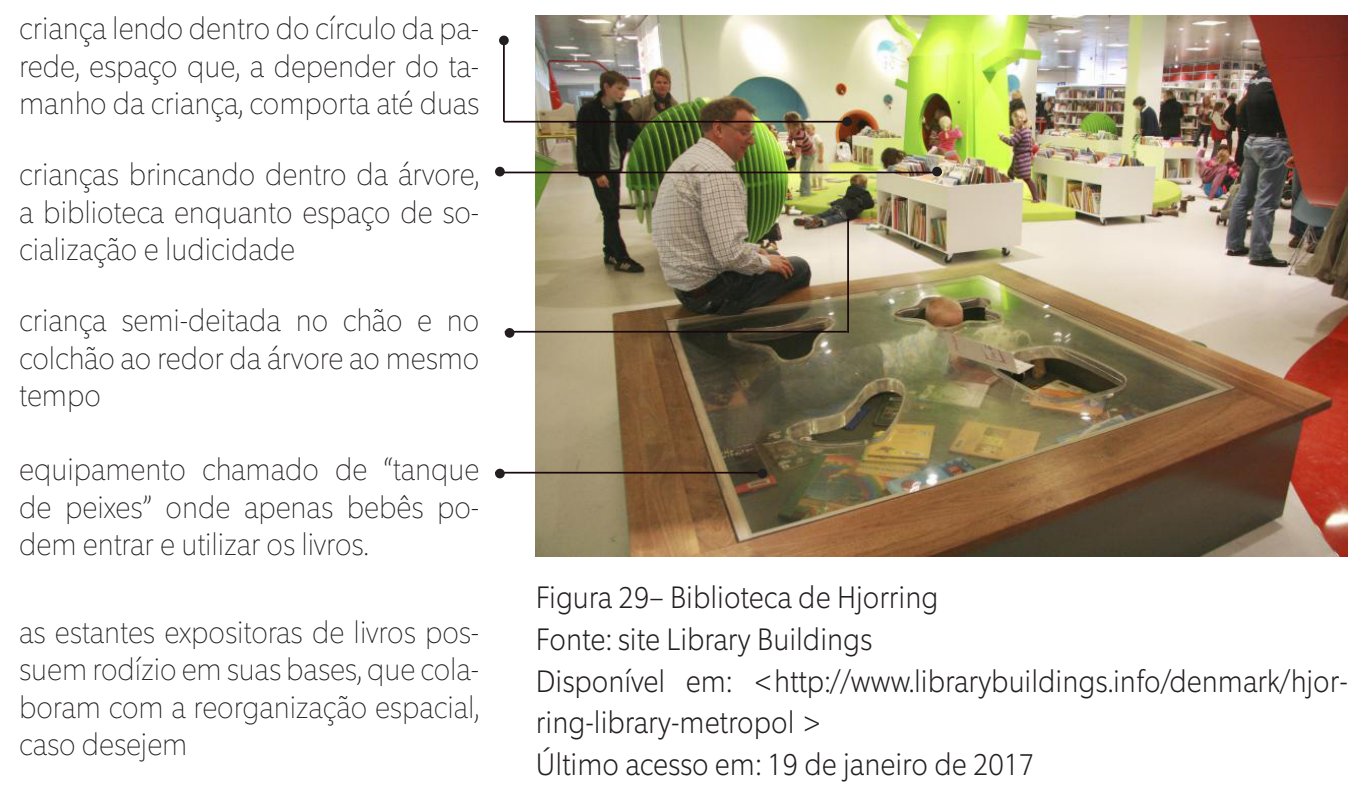

O quadro a seguir expõe de maneira sintetizada os aspectos referentes aos parâmetros selecionados para análise dos ambientes em relação à Biblioteca Hjorring:

\section{QUADRO 5 - ANÁLISE DOS PARÂMETROS NA BIBLIOTECA}

PARÂMETRO 1 - observou-se nas imagens que é possível realizar-se diversas atividades, e que o mobiliário presente possibilita múltiplos arranjos espaciais. o amplo espaço físico desta biblioteca permite a realização de diversas atividades para além da leitura em diversos tipos de ambientes.

PARÂMETRO 9 - não foi possível observar nas fotografias como se dá a delimitação da área voltada para os bibliotecários e outros funcionários. no que diz respeito à iluminação natural, esta foi observada apenas na área voltada para jovens e adolescentes, pois a biblioteca está inserida num complexo de um shopping center, o que dificulta o uso da iluminação natural.

PARÂMETRO 11 - em relação ao uso de tecnologia no local, observou-se a presença, na área infantil de telas planas suspensas em paredes e um totem com uma espécie de tablet com altura que indica ser voltada para uso da criança. não se sabe, no entando a função deste objeto. em outras áreas da biblioteca há espaços voltados para o uso de computadores e outros equipamentos de leitura eletrônicos.

PARÂMETRO 13 - de acordo com as imagens disponibilizadas, notou-se que há diversos assentos (almofadões, bancos, bancadas, sofás, colchonetes) e todos, exceto pela bancada aparentam ser projetados com materiais confortáveis.

PARÂMETRO 14 - o espaço se mostra grande o suficiente para receber uma quantidade considerável de crianças ao mesmo tempo, conforme é possível verificar nas imagens disponibilizadas.

PARÂMETRO 20 - apesar da existência de janelas no local, acredita-se que estas permaneçam fechadas devido ao clima extremamente gélido da Dinamarca, além de que a biblioteca se localiza no interior de um shopping center. 


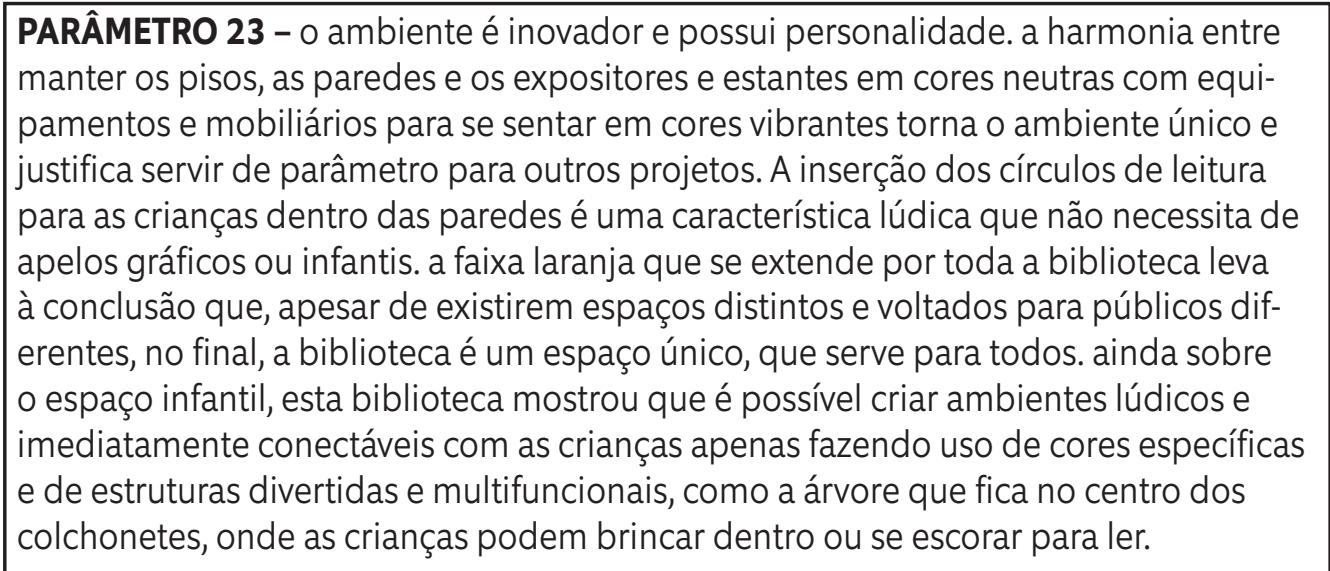

Fonte: Autora

Em relação a esta biblioteca, pode-se concluir que seus aspectos inovadores em termos de projeto, especialmente para o público infantil, justificam sua fama mundial. É interessante notar que, assim como a Biblioteca Niños CONARTE, a ludicidade esta presente sem que se faça uso diretamente de grafismos ou apelos para personagens voltados para o público infantil.

\subsubsection{Biblioteca Pública Ying Yang - Coréia do Sul}

Esta biblioteca foi projetada em 2013 e, de acordo com o site www.designboom.com, busca trazer em seu projeto arquitetônico parâmetros relativos ao sinal filosófico do "yin yang". Assim, o conceito obteve a forma do sinal e também "espacialmente divide o espaço em dois nós funcionais opostos que se complementam, no caso educação e comunicação." Esta biblioteca ganhou o primeiro lugar na categoria de design sustentável do prêmio autodesk, um dos prêmios da Academia Arch-World para 2011-2013.

As imagens a seguir foram extraídas do site www.designboom.com e mostram partes dos ambientes que compõem a biblioteca. A pesquisadora buscou apontar nas imagens a existência ou não de alguns dos Parâmetros de projeto indicados por Kowaltowski (2011) para o projeto escolar, sendo estes adaptados para os ambientes analisados neste capítulo. 
ambientação do teto do espaço com circunferências coloridas que aparentam trazer a ludicidade para o espaço

iluminação natural no ambiente que divide espaço com a elétrica. pontos de luz em altura elevada.

presença computadores na biblioteca pública sendo utilizados por crianças individualmente, demonstra que esta biblioteca já inseriu os equipamento eletrônicos como artefatos de comunicação.

o mobiliário se destaca pela simplicidade das formas e pela harmonia entre as cores das mesas, estantes e cadeiras: sóbrias com detalhes em cores fortes. observa-se que as mesas possuem formato para receber três crianças, indicando que, talvez, o quesito socialização tenha sido levado em consideração no projeto.

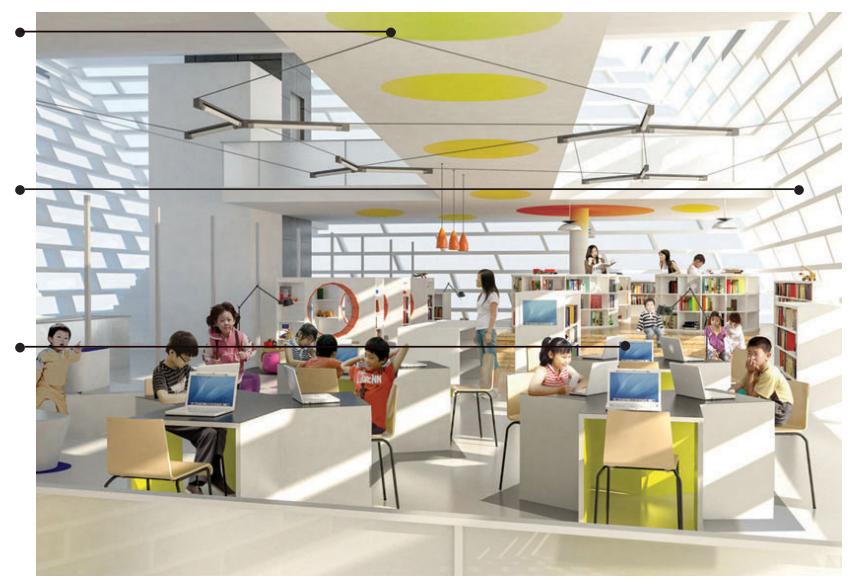

Figura 29 - Biblioteca Pública Yin Yang Fonte: site Design Boom Disponível em: <http://www.designboom.com> Último acesso em: 19 de janeiro de 2017

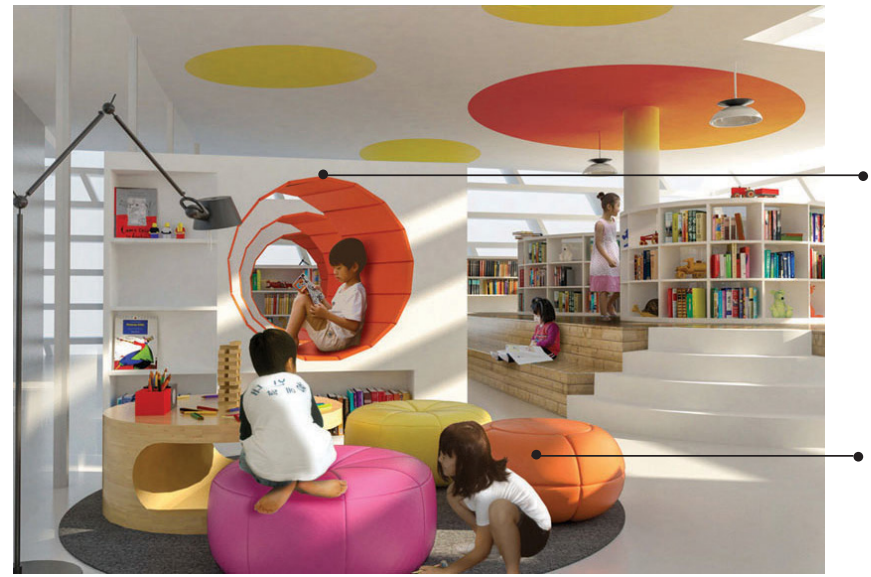

Figura 30 - Biblioteca Pública Yin Yang Fonte: site Design Boom Disponível em: <http://www.designboom.com> Último acesso em: 19 de janeiro de 2017 luminária de piso com iluminação direta para as atividades que acontecem na mesa. nota-se também a presença de jogos e brinquedos na biblioteca.

ambiente de leitura individual semelhante ao da Biblioteca de Hjorring.

as estantes da biblioteca são brancas e a presença da mesinha de madeira e da escadaria numa textura que representa o tijolo dão vida ao espaço.

puffs são uma alternativa de assento. o material aparenta ser confortável para o usuário. as cores vivas colaboram com a ludicidade do ambiente

observa-se com a presença da criança próxima à estante que suas medidas são ideais para o usuário.

O quadro a seguir expõe de maneira sintetizada os aspectos referentes aos parâmetros selecionados para análise dos ambientes em relação à Biblioteca Ying Yang: 
QUADRO 6 - ANÁLISE DOS PARÂMETROS NA BIBLIOTECA

PARÂMETRO 1 - apesar da pouca quantidade de fotografias para análise, observou-se nas imagens que é possível realizar-se diversas atividades, apesar da área voltada para o público infantil não parecer ser muito grande. o mobiliário presente possibilita múltiplos arranjos espaciais. o amplo espaço físico desta biblioteca permite a realização de diversas atividades para além da leitura nos ambientes.

PARÂMETRO 9 - não foi possível observar nas fotografias como se dá a delimitação da área voltada para os bibliotecários e outros funcionários. no que diz respeito à iluminação natural, ela está amplamente presente no espaço em questão, devido ao projeto do prédio, no qual as paredes externas são de vidro.

PARÂMETRO 11 - em relação ao uso de tecnologia no local, observou-se diversos computadores sendo utilizados por crianças em uma das fotografias analisadas. sabe-se que a Coréia do Sul é um país mais avançados na tecnologia digital e com grande número de portadores de eletrônicos, fator que deve impulsionar a presença destes dispositivos em áreas infantis de bibliotecas.

PARÂMETRO 13 - de acordo com as imagens disponibilizadas, notou-se que as cadeiras de madeira não parecem ser confortáveis, do ponto de vista do material que as compõem. o entando, os puffs coloridos aparentam ser projetados com materiais confortáveis.

PARÂMETRO 14 - o espaço se mostra grande o suficiente para receber uma quantidade considerável de crianças ao mesmo tempo, porém não aparenta ser tão espaçoso quanto os espaços destinados ao público infantil das outras duas bibliotecas analisadas.

PARÂMETRO 20 - o ambiente aparentemente não possui ventilação natural

PARÂMETRO 23 - o espaço destinado às crianças nesta biblioteca se assemelha aos outros dois no sentido de ser um espaço amplo que prioriza o lazer e a leitura. no entanto, este ambiente aparenta ser menor que os outros, inclusive pela quantidade de mesas disponibilizada. assim como os outros dois ambientes, a ludicidade fica por conta da inserção de cores vibrantes e alegres em pequenas parcelas, se comparado com a porcentagem neutra das cores das estantes e das mesas. Observou-se que esta biblioteca faz uma composição no ambiente utilizando-se de vários materiais sem tornar o ambiente sobrecarregado ou confuso.

Fonte: Autora

Após a verificação do Estado da Arte para o mobiliário na indústria brasileira como o que existe em termos de referencia mundial em espaços infantis de bibliotecas públicas, será possível tecer análises mais aprofundadas acerca dos estudos de caso que estão presentes no capítulo a seguir. 


$$
\begin{aligned}
& \text { CAPÍTULO } 4 \\
& \text { ESTUDOS DE } \\
& \text { CASO }
\end{aligned}
$$




\subsection{OS OBJETOS DOS ESTUDOS DE CASO}

Esta pesquisa se debruçou em analisar dois estudos de caso, sendo eles uma biblioteca pública infantil e uma biblioteca escolar. A Biblioteca Infantojuvenil Monteiro Lobato, estudo de caso 1, foi selecionada devido a sua importância simbólica para a cidade de São Paulo, pois data de 1936 e foi fundada pelo Departamento de Cultura da cidade de São Paulo, sob o comando de Mário de Andrade num período em que foram feitos grandes esforços para tornar São Paulo referência nacional em cultura. Além disso, é a mais antiga biblioteca pública infantil em funcionamento do país e possui um dos maiores acervos da América Latina. Desta biblioteca foi analisada sua Sala do Acervo Infantil e da Primeira Infância, onde se localiza o acervo voltado para o público desta pesquisa e também onde ocorrem as contações de história nesta biblioteca.

Para manter o sigilo exigido pela Ética na Pesquisa e preservar a identidade dos alunos, conservando sua segurança e integridade, o estudo de caso dois vai se referir à escola que autorizou a análise de suas bibliotecas como Colégio X. O subcapítulo referente a esta escola trará maiores detalhes sobre sua contextualização; mas adianta-se aqui tratar-se de uma escola considerada referência em ensino na cidade de São Paulo e que abriga duas bibliotecas para atender a públicos distintos, sendo uma biblioteca voltada para crianças do Jardim de Infância ao primeiro ano do Ensino Fundamental (a qual chamaremos nesta pesquisa de 
Biblioteca Alfa), e a outra voltada para alunos do segundo ano do Ensino Fundamental em diante (chamada, nesta pesquisa, Biblioteca Beta). Esta pesquisa tem como público crianças entre seis e nove anos fazendo-se necessário, portanto, concentrar suas análises em ambas as bibliotecas desta escola.

A seguir, será apresentado o conceito de Stakeholder Map, método utilizado em ambos os estudos de caso para apontar os grupos que atuam, direta ou indiretamente, para a experiência das crianças nas bibliotecas analisadas.

\subsection{STAKEHOLDER MAP}

A tradicional definição do termo "stakeholder" é "qualquer grupo ou indivíduo que pode afetar ou que é afetado pela conquista dos objetivos da organização" (FREEMAN, 1984). No geral, o conceito trata de como a organização e seus participantes deveriam ser. Em 2004, o autor afirma que a organização em si deve ser feita por meio de um agrupamento de stakeholders e o objetivo da organização, no sentido de empresa ou corporação, deve ser o de administrar seus interesses, necessidades e pontos de vista. Posteriormente, o autor vai aprimorando o conceito de "stakeholder" e, em 2006, define como "os grupos que são vitais para a sobrevivência e para o sucesso da corporação”.

Já Eden \& Ackermann (1998) conceituam "stakeholder" como "pessoas ou pequenos grupos com o poder de obter respostas, de negociar e de mudar o futuro estratégico da organização.”

A importância de se considerar o grupo de stakeholders envolvidos na relação da experiência do usuário com o ambiente estudado advém da "crescente interconexão natural do mundo" (Bryson, 2004, p.23 - tradução nossa). O autor afirma ainda que pensando-se em qualquer problema público, como déficit no desenvolvimento educacional, terrorismo ou aquecimento global, fica claro que o problema envolve ou afeta um grande número de pessoas, grupos e organizações e, portanto, trata-se de um problema complexo, onde vários participantes colaboram e se interrelacionam. 
Assim, esta pesquisa se utiliza do conceito de stakeholder para identificar os agentes que se relacionam direta ou indiretamente com o usuário nas bibliotecas infantis e escolares, tendo como objetivo compreender quem são estes personagens que estão diretamente conectados com a experiência das crianças nos estudos de caso em questão.

Para cada um dos estudos de caso desta pesquisa foi feito um stakeholder diferente que remete as suas conexões com os usuários em questão. Os stakeho/ders foram divididos em dois tipos, que dependem de estar em conexão direta ou não com o usuário. O primeiro grupo, dos stakeholders primários, é formado por grupos de pessoas que se relacionam diretamente com o usuário durante sua experiência nas bibliotecas. Já o segundo grupo, denominado "stakeholders secundários”, são instituições e/ou grupos de pessoas que não se relacionam com o usuário durante sua experiência na biblioteca e que, muitas vezes, nem os conhecem, mas que também são responsáveis pela forma como se dá esta experiência.

Estes stakeholders serão destrinchados de forma mais aprofundada nas sessões pertinentes a cada um dos estudos de caso em particular, resumidos pelo quadro a seguir:

\begin{tabular}{|l|l|l|}
\hline QUADRO 7 - STAKEHOLDERS DOS ESTUDOS DE CASO \\
\hline \multirow{5}{*}{ stakeholders primários } & \multicolumn{1}{|c|}{$\begin{array}{c}\text { Biblioteca Infantojuvenil } \\
\text { Monteiro Lobato }\end{array}$} & \multicolumn{1}{|c|}{ Colégio X } \\
\hline \multirow{5}{*}{ stakeholders secundários } & bibliotecária & bibliotecária \\
\cline { 2 - 3 } & contadora de histórias & contadoras de histórias \\
\cline { 2 - 3 } & pais ou responsáveis & - \\
\cline { 2 - 3 } & professoras & professoras \\
\hline & $\begin{array}{l}\text { arquiteto, designer ou } \\
\text { responsável pela organi- } \\
\text { zação do espaço estudado }\end{array}$ & $\begin{array}{l}\text { arquiteto, designer ou } \\
\text { responsável pela organi- } \\
\text { zação do espaço estudado }\end{array}$ \\
\cline { 2 - 3 } & fornecedores do acervo & fornecedores do acervo \\
\cline { 2 - 3 } & diretora da biblioteca & diretora da escola \\
\hline
\end{tabular}

Fonte: autora 


\subsection{MÉTODOS E FERRAMENTAS}

Com a definição dos stakeholders, foi possível escolher as ferramentas necessárias para coletar os dados referentes a cada um deles. A pertinência na seleção das ferramentas deu-se considerando o tipo de conteúdo a ser coletado, as limitações de base ética na pesquisa e o tempo dedicado a cada uma delas.

Cada um dos estudos de caso necessitou de ferramentas próprias de acordo com seus objetivos de coleta de dados. $O$ quadro a seguir aponta as ferramentas utilizadas para a coleta de dados, indicando para qual stakeholder foram aplicadas.

\begin{tabular}{|c|c|c|c|}
\hline \multicolumn{4}{|c|}{ QUADRO 8 - FERRAMENTAS PARA CADA STAKEHOLDER } \\
\hline Stakeholder & Ferramenta & $\begin{array}{c}\text { Biblioteca Infan- } \\
\text { tojuvenil Monteiro } \\
\text { Lobato }\end{array}$ & Colégio X \\
\hline usuário & Storytelling & & $x$ \\
\hline usuário & $\begin{array}{c}\text { Observação } \\
\text { não-participante }\end{array}$ & $x$ & $x$ \\
\hline bibliotecária & $\begin{array}{c}\text { Entrevista semi-es- } \\
\text { truturada }\end{array}$ & $x$ & $x$ \\
\hline $\begin{array}{l}\text { contadora de } \\
\text { histórias }\end{array}$ & $\begin{array}{c}\text { Entrevista semi-es- } \\
\text { truturada }\end{array}$ & $x$ & $x$ \\
\hline $\begin{array}{c}\text { pais ou responsá- } \\
\text { veis }\end{array}$ & $\begin{array}{l}\text { questionário im- } \\
\text { presso }\end{array}$ & $x$ & \\
\hline
\end{tabular}

Fonte: autora

\subsubsection{Storytelling}

Definido como uma forma de narrativa, o storytelling é uma ferramenta que permite a elaboração conhecimento empático sobre as pessoas por meio de suas experiências pessoais. "Expressando-se por meio do storytelling, o usuário é capaz de descrever seus sonhos e aspirações, ainda que de maneira subjetiva." (KOSKINEN \& BATTARBEE, 2003)

Para esta pesquisa, o uso do storytelling enquanto ferramenta para apurar a forma como as crianças do Colégio X enxergam a biblioteca da instituição foi de suma importância. Com ela, foi possível analisar aspectos subjetivos inerentes às experiências das crianças com o ambiente estudado e seus equipamentos. 
Muitas vezes, elas têm dificuldade em se expressar por meio de entrevistas ou questionário, e o storytelling supre estas dificuldades ao permitir que a criança se debruce sobre o tema da maneira que desejar, sem se sentir pressionada a falar ou intimidada pela presença do pesquisador.

Esta pesquisa utilizou o storytelling com alunos do Colégio $X$, entre seis e nove anos, que levaram a atividade para fazer em casa com o auxílio dos responsáveis. A frase utilizada como base para a atividade foi: "Eu gostaria que a biblioteca da minha escola fosse assim:”.

A pergunta teve como premissa abranger o máximo de conteúdo possível e não ser passível de respostas muito curtas e diretas, que limitasse o potencial de expressão da criança. Além disso, procurou-se desenvolver uma frase que instigasse a criança a trazer dados pertinentes ao estudo de um ambiente construído e os fatores alí implicados, tanto fatores físicos (como o mobiliário e o acervo) quanto fatores mais subjetivos, referentes a conforto, dinâmica e sentimentos da criança para com o ambiente. Na sessão de "Anexos" desta dissertação, encontrasse o documento enviado para os alunos, constando as regras para a aplicação do storytelling.

\subsubsection{Observação Sistemática Não-Participante}

Esta ferramenta de pesquisa implica em um tipo de observação de uma situação em condições controladas, na qual o investigador não interage com seu objeto de estudo enquanto o observa, apresentando-se na cena como um espectador.

Nas observações realizadas no Colégio X, o método apresentou uma distorção em relação à aplicação do mesmo em uma situação ideal. Por estar compartilhando do mesmo ambiente que os alunos, as professoras apresentavam a pesquisadora às crianças, ainda que sem fornecer detalhes sobre a intenção da presença da mesma, muitas vezes apenas justificadas com "A Aline veio ver como é uma aula de biblioteca aqui na escola". Acredita-se, porém, que estas apresentações não tenham influenciado demasiadamente no comportamento dos alunos, pois era raro o desvio da atenção das aulas nas bibliotecas para o local onde a pesquisadora se fixou durante as observações. 
No que diz respeito às observações realizadas na Biblioteca Infantojuvenil Monteiro Lobato (BIJML), pode-se afirmar que a presença da pesquisadora no local das atividades não aparentou influenciar na dinâmica da crianças no local, pois este era muito amplo e a pesquisadora se fixou em um local relativamente longe dos olhares dos usuários.

\subsubsection{Entrevistas Semi-Estruturadas}

Flick (2009, p.149) afirma que ao se realizar entrevistas semi-estruturadas, as perguntas abertas podem ser respondidas com base no conhecimento que o entrevistado possui imediatamente a mão. Além disso, o autor afirma que são feitas perguntas controladas pela teoria e direcionada para as hipóteses.

Nos subcapítulos pertinentes a cada um dos estudos de caso isoladamente, se desdobrará o roteiro utilizado nas entrevistas para os stakeholders, pois a tipologia das bibliotecas foram determinantes no conteúdo das perguntas direcionadas às bibliotecárias e às contadoras de histórias de cada biblioteca.

\subsubsection{Questionário Impresso}

Para a biblioteca de caráter público, foram aplicados questionários com os pais ou responsáveis pelas crianças, com o intuito de compreender a frequência com a qual estas crianças visitam a biblioteca e como os responsáveis enxergam o local e sua dinâmica. Quando permitido pelos responsáveis, foi possível questionar as crianças acerca de sua experiência no passeio à biblioteca e seus elementos preferidos, afim de levantar informações voltadas para a análise do ambiente.

Os critérios estabelecidos para formular as perguntas do questionário e decidir a quantidade de perguntas a serem feitas foram: interferir o mínimo possível na experiência da criança e no momento de lazer com os responsáveis (portanto, foram realizadas perguntas curtas e diretas), não causar constrangimento aos entrevistados (perguntas "leves") e não parecer um questionário longo e cansativo.

A partir daqui, se fará a análise dos estudos de caso de maneira particular, buscando-se utilizar métodos e ferramentas pertinentes a cada um deles. 


\subsection{ESTUDO DE CASO 1 - BIBLIOTECA INFANTOJUVENIL MONTEIRO LOBATO}

O presente estudo de caso buscou investigar a relação da criança entre seis e nove anos com os ambientes da Biblioteca Infantojuvenil Monteiro Lobato (BIJML). Por se tratar de um espaço público, podem ser encontrados usuários de todas as faixas etárias que usufruem da biblioteca de maneiras distintas.

No decorrer dos levantamentos efetuados nas visitas; das observações de uso e atividades, e do desenvolvimento das investigações no local, compreendeu-se que levando-se em consideração a faixa etária estipulada para este estudo, existem dois tipos de usuário que interessam para esta pesquisa: as crianças que visitam a biblioteca em grupos escolares e as que vão acompanhada por seus responsáveis, como pais, avós e babás, por exemplo.

\subsubsection{Sobre a Biblioteca}

A Biblioteca Infantojuvenil Monteiro Lobato recebeu esta denominação em 1955, cinco anos após a inauguração de seu atual prédio. Antes disso, era chamada de Biblioteca Infantil Municipal e foi criada no ano de 1936, na gestão de Mário de Andrade enquanto diretor do extinto Departamento Municipal de Cultura da cidade de São Paulo. Neste sentido, se destaca a relevância desta biblioteca como de vital importância para a história da vida cultural paulistana como já abordado no Capítulo 1 , o que direcionou esta pesquisa para o estudo dos espaços internos do edifício.

A nível de contextualização, os espaços da BIJML abertos para o público serão apresentados a seguir: 


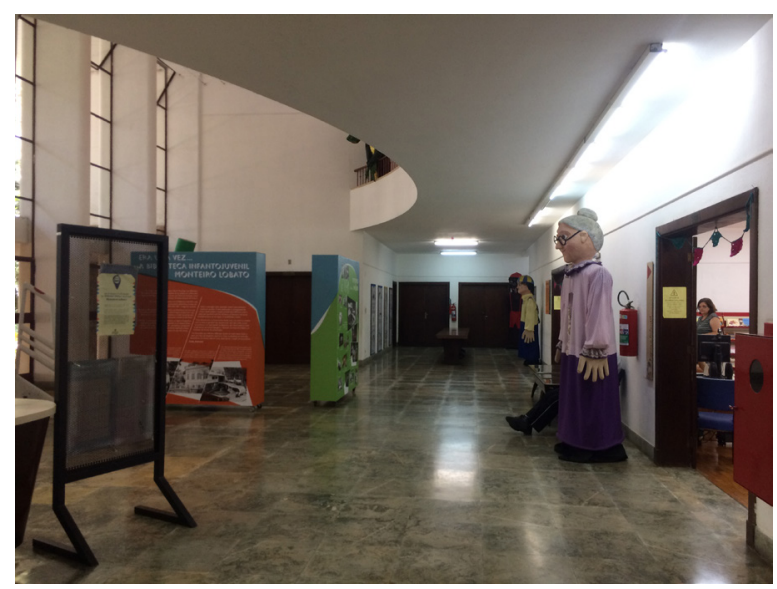

Figura 31 - Biblioteca Infanto Juvenil Monteiro Lobato - Hall de Entrada

Fonte:Autora

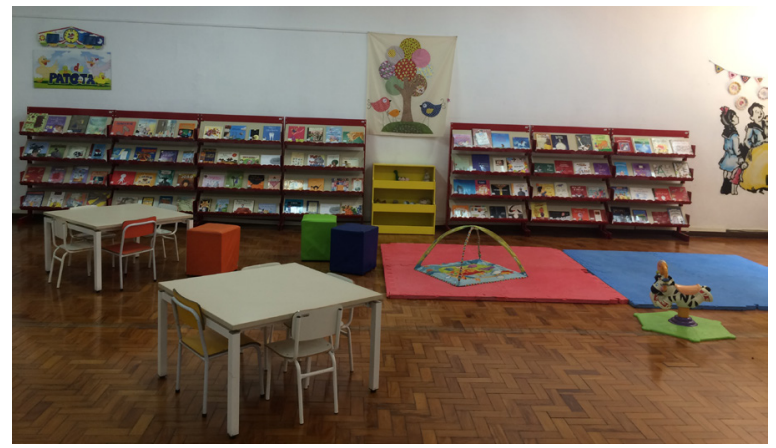

Figura 32 - Biblioteca Infanto Juvenil Monteiro Lobato - Sala do Acervo Infantil e da Primeira Infância (térreo)

Fonte:Autora

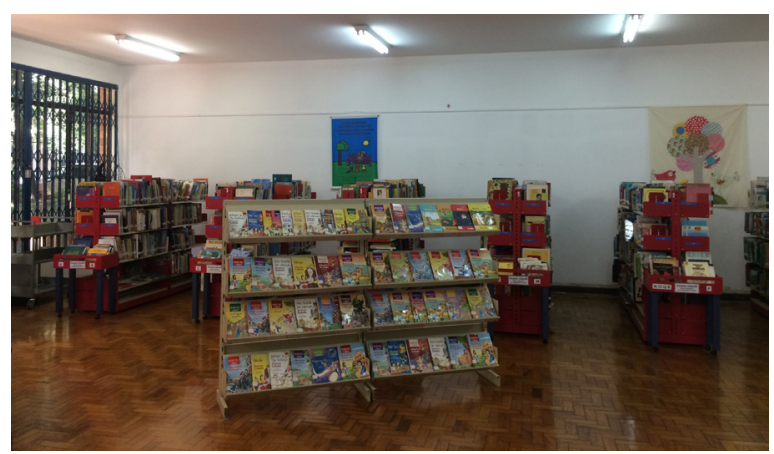

Figura 33 - Biblioteca Infanto Juvenil Monteiro Lobato - Sala do Acervo Infantil e da Primeira Infância (térreo)

Fonte:Autora 


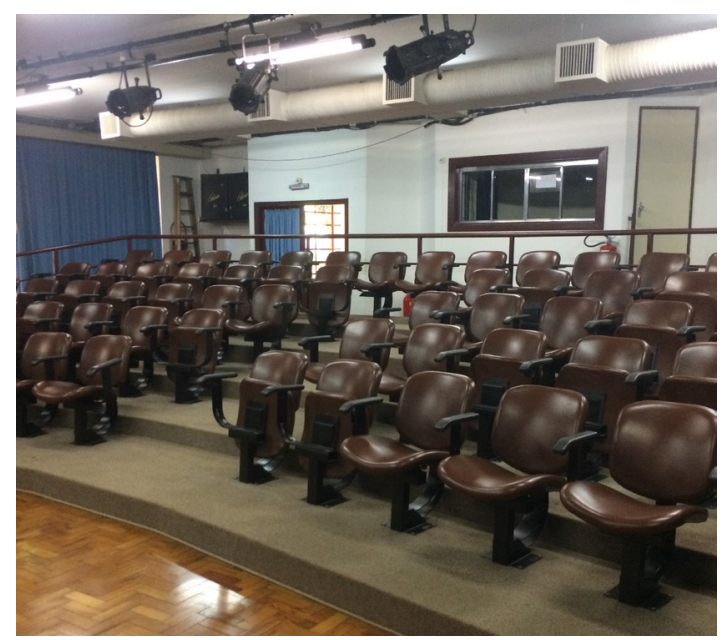

Figura 34 - Biblioteca Infanto Juvenil Monteiro Lobato Teatro e Cinema (térreo)

Fonte:Autora

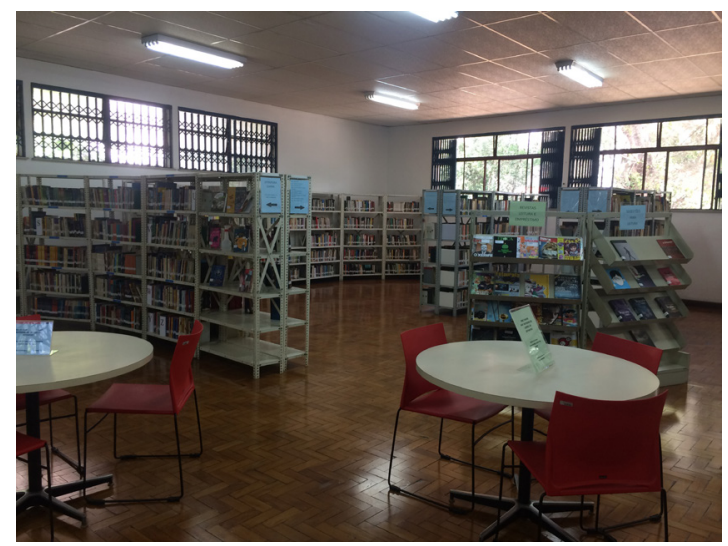

Figura 36 - Biblioteca Infanto Juvenil Monteiro Lobato Sala do Acervo (primeiro andar)

Fonte:Autora

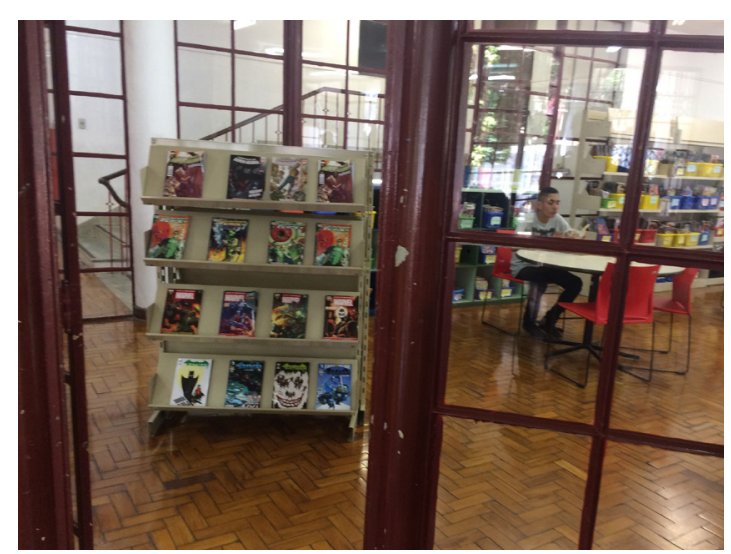

Figura 38 - Gibiteca (primeiro andar) Fonte:Autora

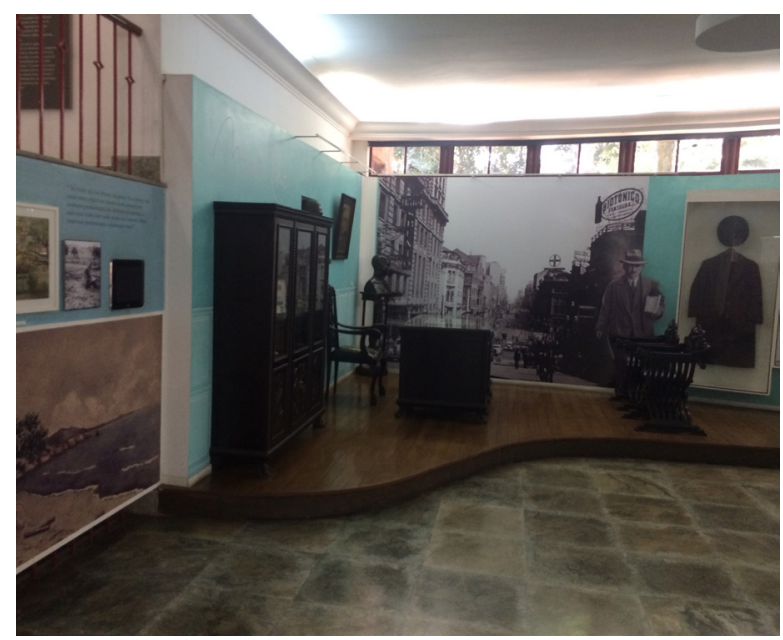

Figura 35 - Biblioteca Infanto Juvenil Monteiro Lobato - Exposição Permanente sobre o escritor Monteiro Lobato (térreo) Fonte:Autora

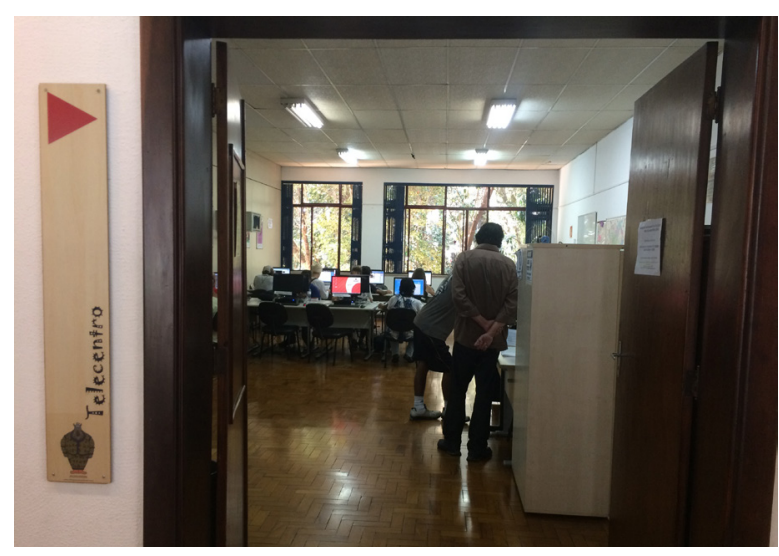

Figura 37 - Telecentro (primeiro andar) Fonte:Autora 
Destes ambientes, o Estudo de Caso 1 se limitará a analisar a experiência da criança na Sala do Acervo Infantil e da Primeira Infância, pois é o local onde o público entre seis e nove anos encontra o acervo pertinente a esta faixa etária e onde se concentram as atividades voltadas para este público.

Em relação aos demais ambientes, como a gibiteca, localizada no primeiro andar do prédio, a grande maioria do acervo desta sala é voltado para adultos e, durando observação da pesquisadora no período investido, a quantidade de crianças na faixa etária pertinente à pesquisa foi irrisória, não permitindo tecer análises acerca do uso deste ambiente por elas.

Quanto ao Telecentro, não é permitido às crianças o uso desta sala, além de que este ambiente foi cedido pela gestão da Biblioteca à Prefeitura de São Paulo, não sendo de responsabilidade da diretoria da Biblioteca Monteiro Lobato.

O teatro e o cinema apenas funcionam quando recebem grupos escolares que agendam previamente uma visita à biblioteca e que desejam assistir a algum filme no local. Durante os meses em que esta pesquisa de campo foi realizada, não houve uso da Sala de Projeção por alunos nesta faixa etária.

Assim, os levantamentos no local tiveram como foco apenas a Sala do Acervo Infantil e da Primeira Infância, onde se localiza todo o acervo de literatura apropriado à faixa etária estudada e abrigam também as atividades de contações de história e as mediações de leitura realizadas pela bibliotecária do local.

\subsubsection{Sala do Acervo Infantil e da Primeira Infância}

O ambiente a ser estudado neste Estudo de Caso é o local da Biblioteca Monteiro Lobato voltado para crianças de zero a 11 anos. Até o primeiro semestre de 2016, a Sala do Acervo Infantil era um espaço destinado apenas a crianças dos seis aos nove anos e a partir de então, passou a abrigar também o acervo e brinquedos voltados para a primeira infância.

A sala não possui paredes internas que separem os espaços ou áreas de influência de atividades dirigidas destinados à primeira infância ou para as crianças maiores, ficando esta divisão a cargo da organização do mobiliário. As imagens a seguir apresentam a Sala do Acervo Infantil e da Primeira Infância: 


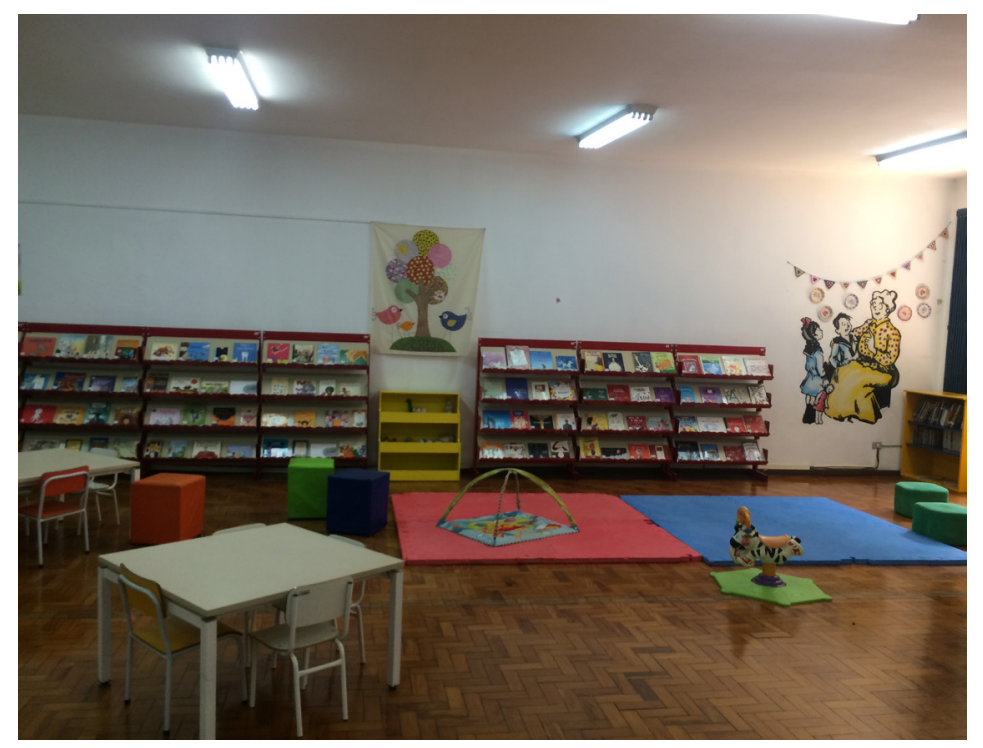

Figura 38 - Sala do Acervo Infantil e da Primeira Infância Fonte:Autora

Neste ambiente percebe-se, na Figura 38, a presença de mesas e cadeiras infantis para uso de crianças de todas as idades. Os puffs são para uso de crianças e adultos. A sala conta com oito módulos de $1 \mathrm{~m} \times 1 \mathrm{~m}$ de tatame, onde ocorrem as contações de história para os grupos escolares. Há também a presença de brinquedos que atendem ao público de bêbes e crianças muito pequenas. Foi feita no ambiente a pintura de dona Benta contando histórias para Narizinho e Pedrinho.

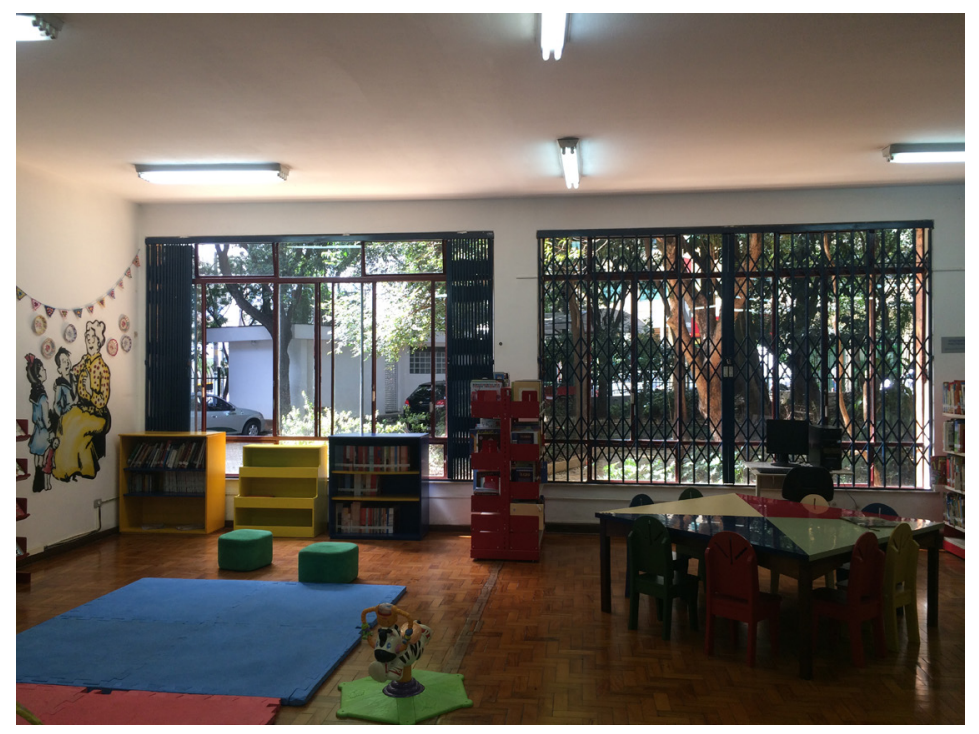

Figura 39 - Sala do Acervo Infantil e da Primeira Infância Fonte:Autora 
A Figura 39 aponta para os tatames já mencionados, onde se realizam as contações de história para as crianças, bem como para as estantes de metal e para as de madeira, que comportamo acervo infantil.

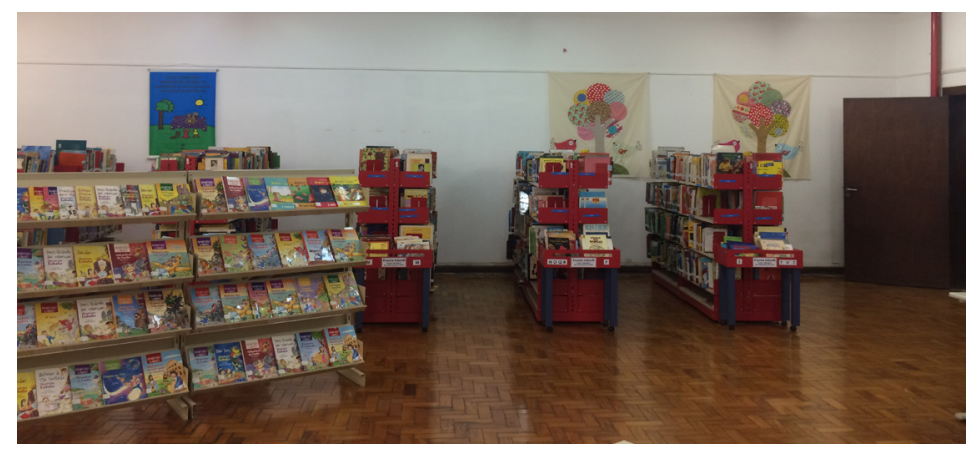

Figura 40 - Sala do Acervo Infantil e da Primeira Infância Fonte:Autora

É possível observar, na Figura 40, as duas estantes mais próximas, que são de metal, comportando apenas o acervo temático Monteiro Lobato. Atrás, é possível ver as estantes vermelhas de metal com o acervo voltado para o público infantil e, a sua frente, expositores vermelhos que comportam o acervo de poesias.

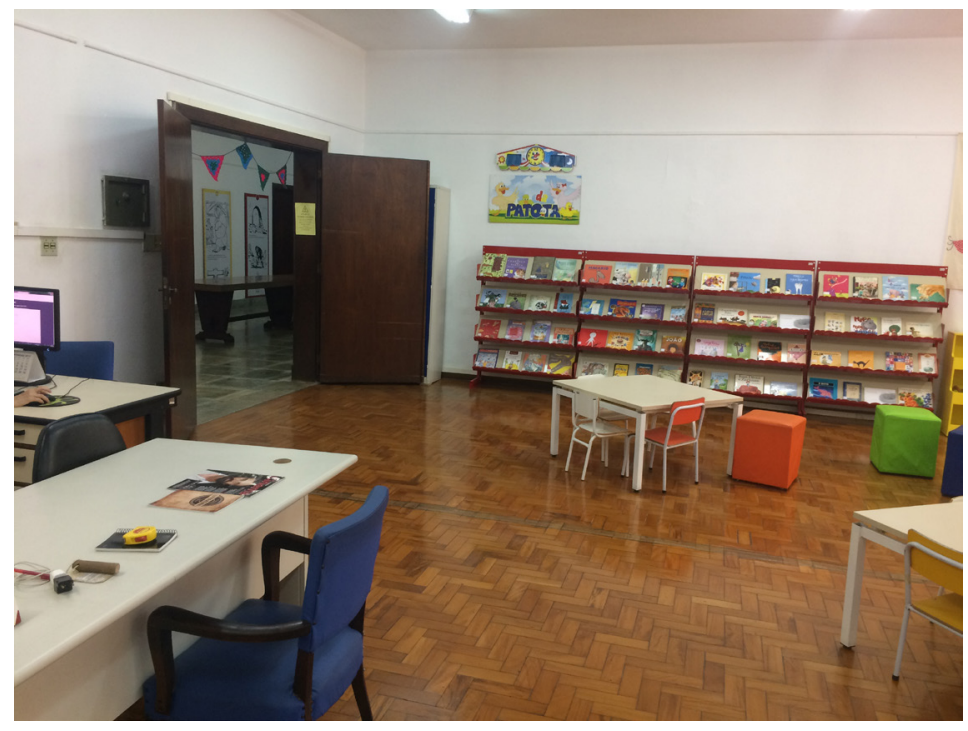

Figura 41 - Sala do Acervo Infantil e da Primeira Infância Fonte:Autora

As Figuras 41 e 42 expõem o espaço voltado para as bibliotecárias na Sala do Acervo Infantil e da Primeira Infância. A Figura 41 permite visualizar uma das portas de entrada ao espaço. 


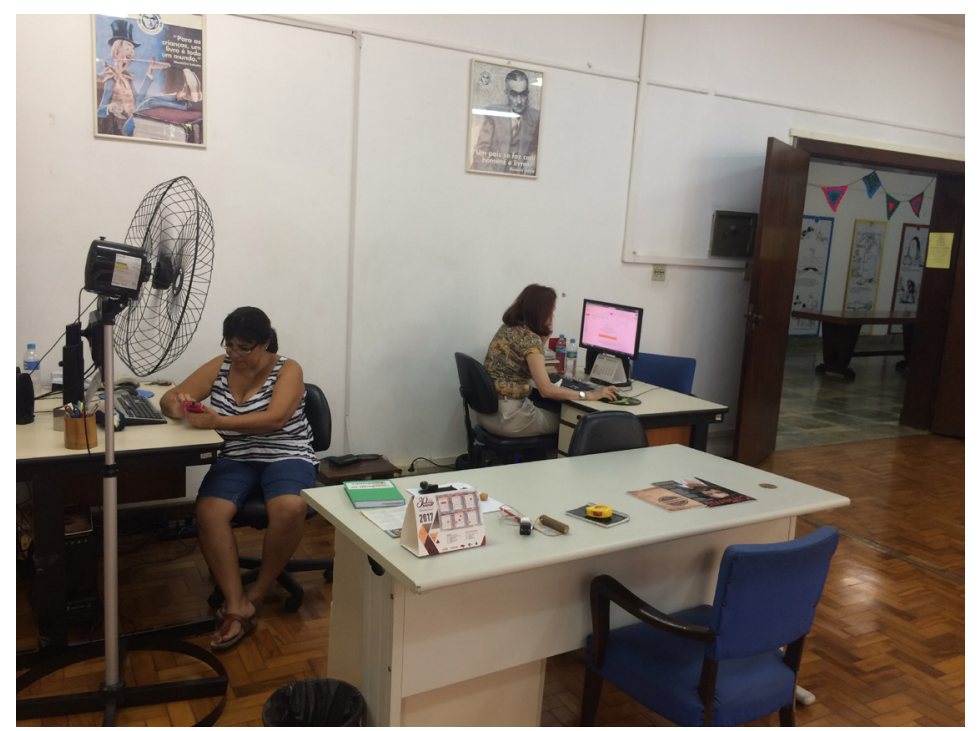

Figura 41 - Sala do Acervo Infantil e da Primeira Infância

Fonte:Autora

QUADRO 9 - RELAÇÃO DE MOBILIÁRIOS E EQUIPAMENTOS DA SALA DO ACERVO INFANTIL E DA PRIMEIRA INFÂNCIA

\section{ESTANTES E EXPOSITORES}

- sete estantes vermelhas de metal com 4 prateleiras cada, para o acervo infantil

- seis estantes expositoras de madeira com 2 divisórias, para o acervo temático poesias

- dois expositores de metal para o acervo temático Monteiro Lobato com 4 prateleiras cada

- duas estantes amarelas e azuis de madeira para o acervo infantil e para guardar brinquedos

- duas estante amarela para guardar brinquedos com 3 prateleiras cada

- sete expositores vermelhos de metal com 4 prateleiras cada para o acervo da primeira infância

\section{MESAS}

- duas mesas brancas para crianças de todas as idades

- uma mesa colorida para crianças de todas as idades

\section{ASSENTOS}

- oito cadeiras coloridas de madeira

- nove cadeiras brancas com estrutura em metal e assento em madeira

- três puffs revestidos com material similar a couro falso

- três puffs verdes revestidos com material similar a camurça

- oito módulos de $1 \mathrm{~m} \times 1 \mathrm{~m}$ de e.v.a. que formam um tatame

\section{MOBILIÁRIO PARA USO DE ADULTOS}

- três mesas para uso da bibliotecárias e dos funcionários

- 3 cadeiras para uso da bibliotecária e dos funcionários

- 2 cadeiras para atendimento ao público

- 1 computador para pesquisa do acervo local

- 1 mesa para o computador

- 1 cadeira para o computador

\section{OUTROS EQUIPAMENTOS}

-2 ventiladores de chão

- 1 carrinho para o acervo (uso aldelto) 
Observa-se que o ambiente é um espaço amplo, sem divisórias estruturais, como paredes, por exemplo, fazendo-se a organização do ambiente em basicamente três grandes grupos: o espaço reservado para atendimento ao público pela bibliotecária, o espaço voltado para a primeira infância e o espaços destinado para crianças maiores.

É possível notar também que não há uma padronização no mobiliário da sala. Os móveis foram adquiridos em épocas diferentes, tendo como pertinência para sua aquisição a necessidade de uma mesa ou uma cadeira, por exemplo, sem levar em consideração a relação estética deste produto como resto do ambiente.

Foi observado que há uma confusão acerca do uso do tatame para os bebês, crianças menores e crianças maiores pois, em certos momentos, todos querem fazer uso deste equipamento, tornando inseguro para os menores dividir o local com as crianças maiores, que às vezes tendem a brincar de correr ou de luta, podendo machucar os menores.

Quanto às estantes voltadas para o acervo infantil, as crianças não têm acesso às estantes de metal vermelhas localizadas no fundo da sala, elas precisam consultar algum funcionário antes de buscar o acervo localizado nestas prateleiras, sob justificativa que eles não sabem colocar na ordem correta de classificação, prejudicando o trabalho dos funcionários quando precisam localizar o acervo.

Notou-se também que a sinalização nos expositores voltados para poesia não são didáticos nem de fácil compreensão para crianças.

Os expositores vermelhos voltados para a primeira infância são os mais procurados por todas as crianças, pois é mais fácil acessá-lo e reconhecer o livro pela capa, conforme está exposto. O mesmo pode ser dito sobre as prateleiras com o acervo Monteiro Lobato, com a diferença que a altura das prateleiras não permite que crianças menores alcancem todo o acervo.

Notou-se que as estantes amarelas estão subutilizadas, com pouco ou nenhum acervo e que as crianças não se interessaram em interagir com estes mobiliários.

As mesas brancas aparentaram servir bem para crianças menores, até os sete anos, tornando-se desconfortáveis para crianças a partir dos oito anos, em geral. Estas mesas e as cadeiras que as acompanham eram menos procuradas pelas crianças que a mesa e as cadeiras de madeira coloridas, que pareciam atender 
melhor o público de faixa etária em torno dos sete e oito anos, mas que também era utilizado por crianças de todas as idades.

Estas considerações foram feitas pela pesquisadora levando em consideração a organização do espaço na maior parte das vezes que o visitou, bem como as observações dos usuários no local, melhor detalhadas no decorrer deste capítulo.

\subsubsection{Stakeholder Map}

A representação gráfica a seguir define o Stakeholder Map com os agentes diretos e indiretos que atuam para viabilizar as atividades referentes à Biblioteca Infantojuvenil Monteiro Lobato, excluindo aqueles ligados ao mercado editorial e autoraL, às atividades de serviços e operação de infraestrutura para a manutenção e conservação do edifício e dos materiais; e os atuantes na política e planejamento publico:

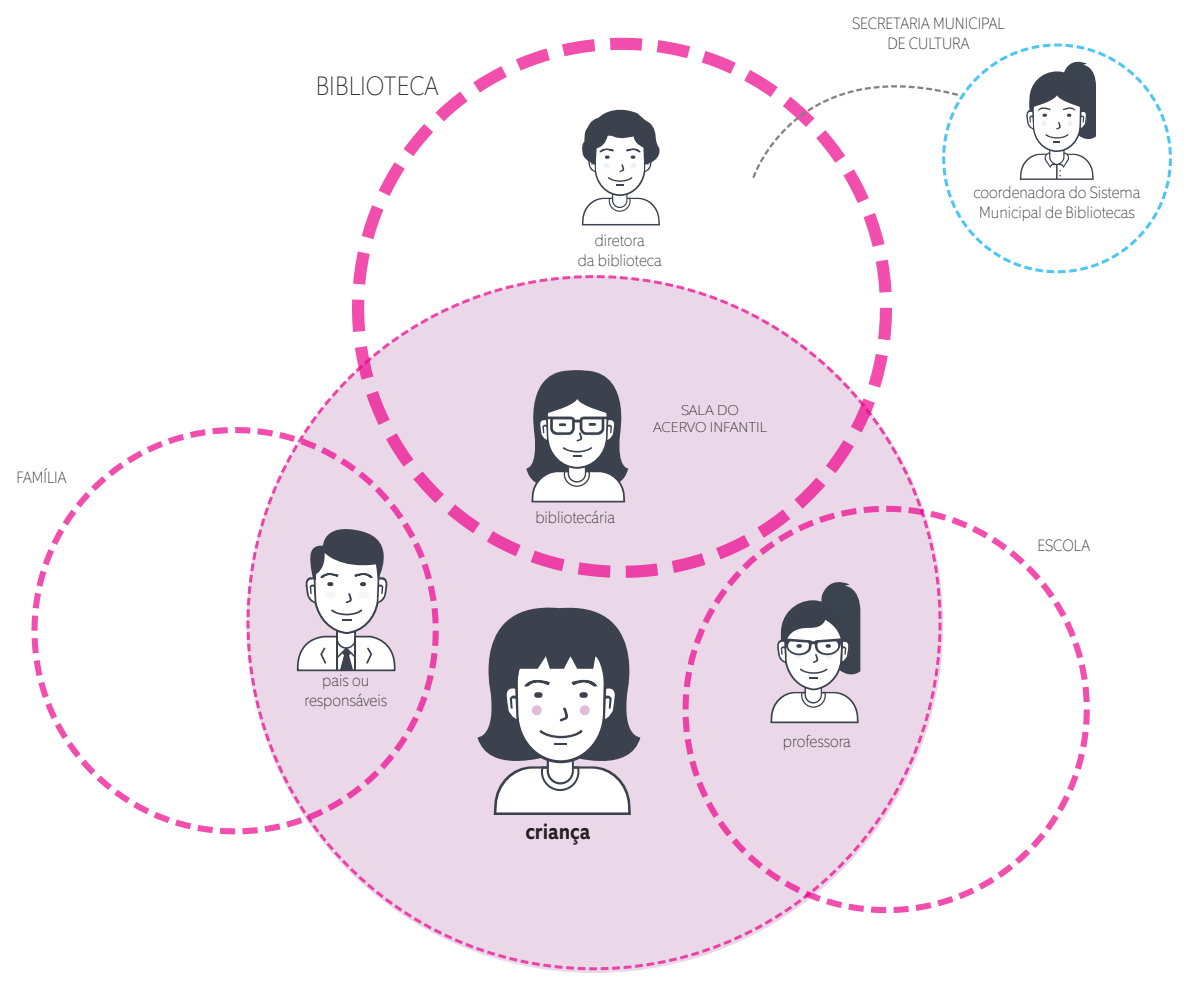

Figura 42 - Stakeholder Map para a BIJML

Fonte:Autora 
Optou-se por contemplar ambos os tipos de usuário que interessam a esta pesquisa (crianças que vão à biblioteca acompanhada de pais ou responsáveis e as que vão por meio de excursão escolar) em um único Stakeholder Map, pois ambos usufruem da mesma Sala do Acervo Infantil, sendo que os distingue são: os tipos de acompanhantes, e na atividade de contação de histórias, que é realizada para os grupos escolares.

A bibliotecária cumpre papel preponderante no contato com as crianças, sendo ela o stakeholder escolhido para investigação pois a diretora apesar de ser a gestora de todo o prédio, usualmente não entra em contato com as crianças. Além disso, questões relativas aos cuidados e manutenção do ambiente aqui estudado são de competência da Secretaria Municipal de Cultura, responsável, dentre outras funções, pela aquisição do acervo infantil e da compra dos equipamentos e mobiliários pertinentes a este ambiente.

As professoras que acompanharam as crianças também não contribuíram para a pesquisa, porque quando abordadas alegaram que precisavam ajudar a conduzir crianças e atividades, sem condições de tempo, atenção ou disponibilidade para fornecer entrevista ou responder a perguntas.

Quanto à coordenadora do Sistema Municipal de Bibliotecas, órgão da prefeitura do município de São Paulo responsável por todas as bibliotecas públicas da cidade, não houve retorno as nossas solicitações de entrevista; respostas a questionário por internet ou possibilidade de contato, inviabilizando acesso aos dados sobre políticas e planejamento da atividade, serviço ou espaços.

\subsubsection{Métodos e Ferramentas}

Foram aplicadas ferramentas distintas para cada um dos stakeholders, com o objetivo de extrair o maior número de informações úteis com qualidade.

\subsubsection{1 - Entrevista com a bibliotecária}

O papel da bibliotecária é de suma importância para a plena experiência da criança na Biblioteca Monteiro Lobato. Suas funções estão relacionadas à gestão da Sala do Acervo Infantil e da Primeira Infância como organização, dis- 
tribuição e empréstimo do acervo, arranjo do layout e distribuição dos moveis e materiais deste ambiente e recepção dos usuários da biblioteca que adentram nesta sala. Além disso, ela também recepciona os grupos escolares que visitam a biblioteca, apresentando as instalações da mesma e é responsável pela atividade de contação de histórias e mediação de leitura para estes grupos.

Para compreender como a bibliotecária atua, foi feita uma entrevista individual semi-estruturada orientada por roteiro previamente elaborado seguindo as etapas de preparação das perguntas, agendamento da entrevista, realização da entrevista com anotações de apontamentos e gravação de áudio autorizada pela entrevistada, transcrição da gravação e análise dos dados obtidos.

Os temas abordaram aspectos relacionados ao espaço, às atividades ali realizadas e ao papel da biblioteca pública infantil para a criança, que podem ser visualizados em sua totalidade no Apêndice Digital, disponível em CD-Room.

\subsubsection{2 - Observação dos grupos escolares}

O procedimento de observação não-participante por parte da pesquisadora se deu entre os meses de junho e setembro de 2016 e ocorreu na Sala do Acervo Infantil e da Primeira Infância. Os grupos escolares foram recebidos pela bibliotecária e faziam um breve passeio pelas dependências da biblioteca antes de entrarem na Sala do Acervo para o momento de contação de história e de leitura livre.

Devido a proibição por parte dos gestores da biblioteca, não foi possível documentar as imagens por fotografias ou filmagens das crianças no momento das atividades. Entretanto, foram feitas anotações e esboços de croquis para representar os principais pontos observados pela pesquisadora.

Durante as observações, a pesquisadora não interagiu com as crianças e permaneceu o mais longe possível destas, visando não distraí-las com sua presença no ambiente. Buscou-se notar aspectos referentes ao comportamento dos alunos durante este momento da visita, sua relação com o mobiliário e com os equipamentos ali presentes, expressões que trouxessem evidências de suas emoções durante as atividades; e a socialização entre as crianças e destas com as professoras e com a bibliotecária. Além disso, tomou-se o cuidado de tentar captar 
e compreender se o layout disponível e os equipamentos ali presentes colaboravam para uma boa execução das atividades propostas.

\subsubsection{3 - Observação das crianças com seus responsáveis}

Também de caráter não-participante, estas observações foram feitas com crianças na faixa etária selecionada que frequentaram a biblioteca acompanhadas por seus responsáveis. Neste caso também as observações foram feitas apenas na Sala do Acervo Infantil, pelas mesmas razões que concernem as observações com os grupos escolares.

O único momento em que a criança foi abordada pela pesquisadora neste caso foi para responder a uma das perguntas do questionário aplicado com os seus respectivos responsáveis, mas não houve utilização de gravador de som ou de vídeo e nem fotografia das crianças.

Buscou-se notar aspectos referentes ao comportamento das crianças na Sala do Acervo, sua relação com o mobiliário e com os equipamentos ali presentes, expressões que trouxessem evidências de suas emoções e comportamentos durante a visita, sua interação com seus responsáveis e/ou com outras crianças presentes. Foram observados também aspectos relativos ao mobiliário e equipamentos ali presentes que corroborassem para o entendimento do papel destes objetos na vivência das crianças neste ambiente.

\subsubsection{4 - Questionário com os responsáveis}

Aplicado com os pais ou responsáveis que acompanharam as crianças à Monteiro Lobato, o questionário tinha como objetivo coletar dados que apontassem a representação da biblioteca infantil para os pais das crianças e perguntas acerca do ambiente da Sala de Acervo Infantil e seus componentes.

As perguntas tinham formato curto e de fácil resposta, que demandassem pouca elaboração em suas respostas, escolha justificada para coletar o máximo de respostas em tempo mínimo, pois em testes anteriores, os adultos se mostraram impacientes para responder questionamentos mais complexos visando se ajustar a disponibilidade dos adultos entrevistados.

O conjunto de perguntas pertinentes ao questionário pode ser encontra- 
do no apêndice deste documento.

\subsubsection{Resultados obtidos}

A seguir serão apresentados os resultados obtidos após as análises dos dados coletados com cada um dos stakeholders:

\subsubsection{1 - Entrevista com a bibliotecária}

Após transcrição na íntegra do áudio desta entrevista e análise do conteúdo obtido, foram criadas categorias que abordavam temas semelhantes para melhor compreender a visão da bibliotecária acerca dos aspectos importantes para esta pesquisa.

\subsubsection{1 - Biblioteca: dispositivo cultural}

A bibliotecária em questão atua em bibliotecas públicas na cidade de São Paulo há aproximadamente 25 anos. Acredita-se que esta experiência com a rotina de bibliotecas públicas dá à profissional credibilidade acerca de sua fala sobre a importância da biblioteca pública na formação da criança.

Para ela, quando a criança frequenta a biblioteca pública, ela entra em contato com outras crianças, o que possibilita a socialização com indivíduos que possuem outra vivência, agregando novas experiências na vida desta criança.

"E quando ela esta aqui, ela aprende a dividir com outras crianças um brinquedo ou ler um livro junto, ou se tem alguém contando uma historia ela pode chegar perto e ouvir com as outras crianças, em grupo e não só na casa dela, na caminha dela com os pais antes de dormir única e exclusivamente para ela. Aqui não, é para todos. Ela vai aprendendo, fazendo amiguinhos, dividindo. Ela pode trazer um livro dela, ela deixa outra criança ver o que é dela."

Além disso, ao retirar livros do acervo público por empréstimo ou ler na própria biblioteca, a criança passa a compreender a existência e a importância do bem público, que pertence a ela e a todas as outras crianças. Desde cedo, é possível ensinar às crianças a noção de bem público. 
"então ela tem que cuidar (do livro), é um bem publico, saber conservar."

A bibliotecária cita também a importância do tamanho e da qualidade do acervo da Biblioteca Monteiro Lobato que, por ser uma biblioteca pública, está disponível para todos os cidadãos.

"E uma biblioteca infantil, de repente sem nem ter ideia, pode já estar construindo esse respeito ao bem publico na cabeça da criança, isso é muito sério."

Outro ponto relevante para esta pesquisa diz respeito ao público que frequenta a biblioteca em questão. A bibliotecária afirma, durante a entrevista, que grande parte dos frequentadores da biblioteca são pessoas de menor poder aquisitivo que desfrutam do acervo, e trabalhadores do entorno que constantemente retiram em empréstimo livros para que seus filhos possam ler em casa, devido à distância entre seus lares e a biblioteca.

\subsubsection{2 - O papel da bibliotecária em relação ao acervo e ao espaço}

Em se tratar do mobiliário pertinente a Sala do Acervo e da Primeira Infância, a bibliotecária afirma que tudo é escolhido e encomendado pelo departamento competente do Sistema Municipal de Bibliotecas. A entrevistada afirmou ainda que ela, responsável por esta sala, não é consultada sobre a escolha dos mobiliários que ali chegam. O mesmo ocorre com o acervo, sobre o qual ela pode opinar e sugerir títulos, mas a escolha dos mesmos fica a cargo do mesmo departamento acima mencionado.

"Não sei se felizmente ou infelizmente nada é perguntado a nós. Quando você vê, a coisa tá chegando. Eles avisam que vem um móvel novo, e tudo bem. Eles que pesquisam, eles que vão atrás, eles que consultam."

Estas informações indicam um abismo entre a realidade do cotidiano, vivido pela bibliotecária em questão e a aquisição do acervo e do mobiliário para esta sala, que é feito por pessoas que não estão familiarizadas com a rotina vivida 
nesta sala, fator este que pode ser uma das razões para a falta de unidade em relação ao mobiliário deste ambiente.

\subsubsection{3 - A organização do ambiente e o mobiliário ofertado}

Conforme explicado no tópico anterior, a bibliotecária não é consultada acerca do mobiliário que chega para a Sala do Acervo Infantil, de modo que ela organiza o espaço da forma que acredita ser a melhor com os móveis oferecidos.

Quando questionada sobre possíveis mudanças que faria no ambiente para que as atividades ali realizadas acontecessem da melhor forma, a entrevistada mencionou que gostaria que o ambiente fosse mais "alegre", o que indica o desejo por novas possibilidades de ambientação voltados para o público infantil.

"...por cuidar de um espaço infantil eu colocaria coisas mais alegres, mais felizes, mais lúdicas, que atraiam mais as crianças..."

Além disso, aponta para a dificuldade que as crianças com mais de seis anos apresentam para lidar com o acervo disposto e visível nas estantes só com a parte da lombada do documento / livro diferentemente do acervo voltado para a primeira infância.

"Esse lado da primeira infância tá legal, a criança pequenininha bate o olho já vê o desenho, vê a ilustração, vê a capa. Mas aqui já tem uma coisa que dificulta muito mais. Para o bibliotecário ou para o adulto tudo bem, mas não para uma criança. Eu modificaria mas não sei ainda como seria isso."

Quando questionada sobre a capacidade física da Sala para receber grupos escolares para contação de histórias, explicou que há momentos em que chegam a receber até 70 crianças de uma vez e que o tatame no qual as crianças são agrupadas para ouvir à história não comporta a quantidade de alunos em questão, apontando para comprometimento da atividade devido a falta de estrutura física para receber o público. 
"O espaço já chegou a ficar bem pequeno. Sessenta ou setenta crianças de uma escola aqui vira um angu de caroço, é uma loucura. Porque você perde até o domínio da situação, de tentar entretê-los e a preocupação com o material, com acervo."

\subsubsection{4 - O uso de suportes de leitura eletrônicos}

Quando questionada acerca do uso de computadores por crianças na biblioteca, a entrevistada afirmou que não existe condições para atender a este tipo de demanda devido à necessidade de contar pessoas responsáveis por monitorar o conteúdo acessado pelas crianças. Além disso, afirmou desconhecer qualquer projeto ou iniciativa para os próximos meses neste sentido.

Sobre o computador que se encontra na Sala, a bibliotecária afirma que é para uso de adultos que queiram realizar pesquisas referentes ao acervo, tanto da Monteiro Lobato quanto de qualquer outra biblioteca do Sistema de Bibliotecas Públicas da Rede Municipal, sendo vetado o uso deste equipamento pelas crianças.

Foi perguntado também se havia alguma possibilidade de ações voltadas para a inserção de tablets ou kindles como forma alternativa de leitura nesta biblioteca. A bibliotecária afirma que também desconhece esta possibilidade para o futuro próximo e que por um lado, acredita que a biblioteca deve se manter como um espaço para o livro impresso, pois seria o momento da criança explorar diferentes texturas, de tocar na ilustração. Por outro ângulo, afirma também que se a biblioteca pública disponibilizasse este tipo de suporte de leitura diferente, crianças mais humildes, com pouco ou nenhum acesso a este tipo de tecnologia poderia usufruir desta forma alternativa de leitura.

\subsubsection{2 - Observação dos grupos escolares}

Entre os meses de junho a novembro de 2016, foram observados seis grupos escolares, cuja faixa etária condizia com o escopo desta pesquisa, que visitaram a Biblioteca Infantojuvenil Monteiro Lobato usando como a observação não-participante, sem que houvesse qualquer contato com os alunos observados durante as visitas.

Com este procedimento, buscou-se coletar evidências que levem a com- 
preender a maneira como a criança que visita a biblioteca em grupo escolar se apropria do espaço da Sala do Acervo Infantil.

Devido a impossibilidade de se utilizar da filmagem, da gravação ou da fotografia como ferramentas para as observações, foram feitas anotações e croquis durante as visitas.

O quadro a seguir sintetiza as informações acerca dos grupos observados, a quantidade de crianças presentes, dentre outras informações pertinentes à contextualização para a compreensão dos resultados obtidos com as visitas. O nome das escolas foi mantido em sigilo para preservar a identidade das mesmas.

\begin{tabular}{|c|c|c|c|c|}
\hline \multicolumn{5}{|c|}{ QUADRO 10 - INFORMAÇÕES SOBRE OS GRUPOS ESCOLARES OBSERVADOS } \\
\hline Grupo & Idade das crianças & $\begin{array}{c}\text { Quantidade de } \\
\text { alunos }\end{array}$ & $\begin{array}{c}\text { Duração da obser- } \\
\text { vação }\end{array}$ & Atividades \\
\hline A & 5 e 6 anos & 33 & 40 minutos & \multirow{4}{*}{$\begin{array}{l}\text { contação de } \\
\text { histórias e leitura } \\
\text { livre }\end{array}$} \\
\hline B & 6 anos & 30 & 25 minutos & \\
\hline $\mathrm{C}$ & 8 anos & 34 & 30 minutos & \\
\hline D & 7 anos & 22 & 25 minutos & \\
\hline
\end{tabular}

Fonte: autora

\subsubsection{1 - As atividades}

Todos os grupos observados realizaram as mesmas atividades na visita à Biblioteca Monteiro Lobato, iniciando com um tour pelas dependências liderado pela bibliotecária que explicava curiosidades sobre o local e parte da história da Monteiro Lobato, seguido de breve lanche antes de entrarem na Sala do Acervo Infantil e da Primeira Infância para a contação de histórias e, posteriormente, leitura livre. O tempo estimado na tabela anterior contabiliza apenas o relacionado a observação das crianças neste dois espaços.

Os resultados obtidos com a observação dos alunos durante as atividades estão divididos em dois grupos, de acordo com as atividades e as condições encontradas nos procedimentos como, por exemplo, durante a contação de histórias os alunos seguiam comandos específicos que limitavam sua liberdade corporal e de atenção, enquanto que no momento de leitura livre, o comportamento das crianças era mais natural, gerando dados de naturezas diferentes. 


\subsection{2 - Contação de histórias}

Na Sala do Acervo Infantil, as crianças eram direcionadas pelas professoras e pela bibliotecária para sentar no tatame de e.v.a., localizado próximo à janela; a atividade durava aproximadamente 10 minutos, sendo realizada pela bibliotecária ou pela chefe de Departamento da Biblioteca.

O quadro a seguir aponta os aspectos que foram analisados durante esta atividade:

\begin{tabular}{|l|}
\hline QUADRO 11 - ASPECTOS ANALISADOS DURANTE A ATIVIDADE \\
\hline $\mathbf{1}$ - Apropriação do ambiente e de seus componentes \\
\hline $\mathbf{2}$ - Conforto físico durante a atividade \\
\hline $\mathbf{3}$ - Interação com a atividade \\
\hline
\end{tabular}

Fonte: autora

1 - Apropriação do ambiente e de seus componentes

Por terem sido instruídas a caminharem em direção ao tatame e sentar para ouvir à história, os alunos, não tiveram a oportunidade de interagir com nenhum elemento presente na Sala do Acervo, apesar de seu nítido interesse em explorar o ambiente e o acervo. Devido à grande quantidade de alunos, observou-se dificuldade por parte das professoras responsáveis em controlar o grupo, retardando o inicio da atividade. Considerando-se que aquelas crianças estavam tendo seu primeiro contato com a biblioteca e com esta sala, local de maior interesse para esta faixa etária, observou-se o desapontamento das crianças por não poderem usufruir do local, ainda que momentaneamente.

2 - Conforto físico durante a atividade

A quantidade de crianças no tatame de e.v.a., cuja área totalizava num retângulo de 8m2, superlotava o espaço disponível para o público em questão.

Desta forma, elas eram orientadas a se sentar com as pernas dobradas. Além disso, verificou-se que a proximidade entre as crianças despertava motivos para desavença ou desconforto entre elas, por estarem com os corpos encostando uns nos outros.

Foi notado que muitos alunos exprimiram semblantes de dor e de cansaço em permanecer sentados dessa forma, e vários tentaram mudar de posição 
com a intenção de ficarem mais confortáveis mas, na maioria dos casos, sem sucesso. Além disso, foi observado o problema da barreira visual que alguns alunos sentados mais a frente causavam em outros que estavam nas filas mais distantes da contadora de histórias.

As imagens a seguir representam as principais posições observadas pelos alunos durante esta atividade:

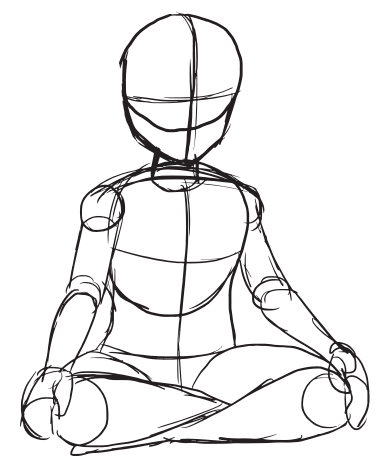

As crianças, de início se sentavam assim, mas não durava muito tempo. Esta também era uma posição de passagem que indicava alongamento do corpo ou concentração em relação à atividade.

Figura 43 - Principais posições realizadas pelas crianças observadas Fonte:Autora

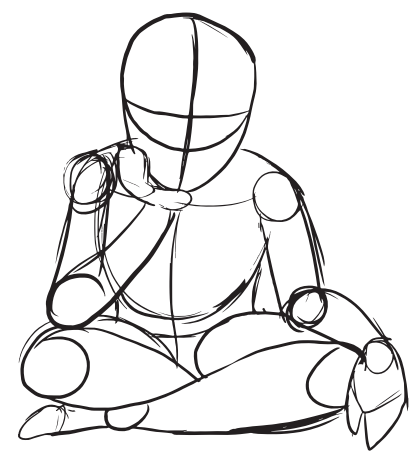

Esta posição foi observada em várias crianças durante boa parte da atividade, principalmente as que estavam sentadas mais próximas da contada de histórias.

Figura 44 - Principais posições realizadas pelas crianças observadas Fonte:Autora

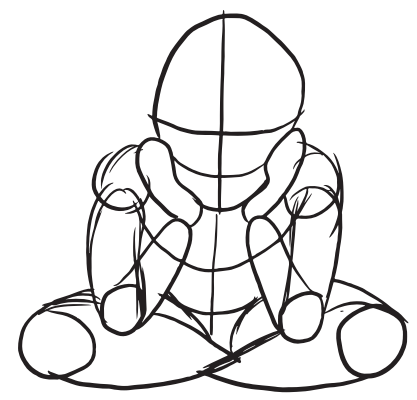

Muitas crianças observadas passaram por esta posição, que demonstrava cansaço e/ou tédio, além da impossibilidade de se sentar de outras maneiras, devido às ordens das professoras e do pouco espaço oferecido para a realização da atividade.

Figura 45 - Principais posições realizadas pelas crianças observadas Fonte:Autora 
Estas observações ressaltam a importância de se ter um ambiente preparado para receber seu público (nas dimensões e aspectos de conforto físico e visual), de forma a permitir que a atividade seja realizada com sucesso. Espaços com déficit em seus equipamentos e mobiliários podem, inclusive, causar danos físicos a seus usuários ou desmotiva-los em relação a atividade a ser realizada ali.

3 - Interação com a atividade

Os alunos demonstraram bastante envolvimento com a contação de histórias, participando ativamente da proposta e se divertindo com a profissional, fato positivo em prol da apropriação do lugar. Esta observação ratifica a a contação de histórias como estratégia de estreitamento de vínculos entre a bibliotecária e as crianças e estimula a permanência dos alunos na biblioteca infantil, além de mostrar a eles a existência das múltiplas possibilidades culturais e educativas da biblioteca pública e infantil. Acredita-se, porém, que em condições espaciais mais favoráveis, a experiência destes alunos teria vindo a ser mais proveitosa.

\subsection{3 - Leitura Livre}

Após a contação de histórias, os alunos tiveram entre 10 e 20 minutos para usufruir da leitura livre na Sala do Acervo, com instruções sobre materiais e organização do acervo nas estantes e expositores: os alunos foram instruíd os a não guardar os livros após retira-los das estantes e também a não mexerem nas estantes que se localizavam no fundo da sala (explicitadas na figura a seguir):

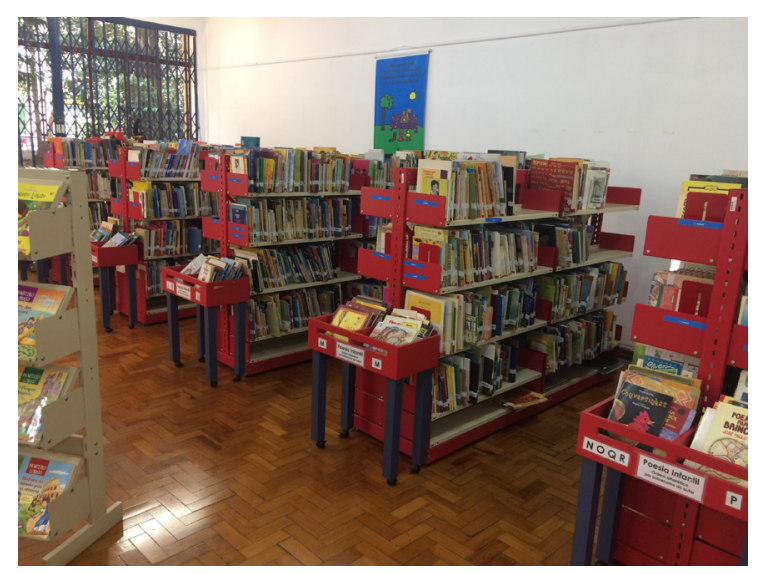

Figura 46 - Estantes proibídas para as crianças Fonte:Autora 
O quadro a seguir aponta os aspectos que foram analisados durante esta atividade.

\begin{tabular}{|l|}
\hline QUADRO 12 - ASPECTOS ANALISADOS DURANTE A ATIVIDADE \\
\hline $\mathbf{1}$ - Apropriação do ambiente e de seus componentes \\
\hline $\mathbf{2}$ - Relacionamento com os colegas e professores \\
\hline $\mathbf{3}$ - Conforto físico durante a atividade \\
\hline $\mathbf{4}$ - Interação com a atividade \\
\hline
\end{tabular}

Fonte: Autora

1 - Apropriação do ambiente e de seus componentes

Durante a leitura, buscou-se observar a intimidade da criança com o ambiente e seus equipamentos. Todos os grupos observados demonstraram comportamento similar, que será discutido a seguir:

- O acervo, estantes e expositores:

Devido à limitação imposta pela gestão da biblioteca acerca das estantes de livre acesso aos alunos, notou-se que parte das crianças demonstraram frustração e curiosidade sobre os livros em outras estantes com os quais não poderiam interagir.

Com a parte do acervo permitida, os alunos não demonstraram intimidação para se apropriar, folheando e escolhendo aleatoriamente os livros nos expositores e nas estantes. Poucos alunos, principalmente os de seis anos, tiveram dificuldade em alcançar livros na prateleira mais alta dos expositores vermelhos destinados ao acervo da primeira infância. Estes ficavam nas pontas dos pés e esticavam os braços para alcançar os livros, mas nem todos conseguiram realizar a ação. O mesmo ocorreu com outros alunos (entre seis e nove anos) em relação às estantes com acervo especial do autor Monteiro Lobato e com as outras permitidas para estas crianças.

Esta dificuldade observada de alcance e manipulação do acervo exposto reforça a necessidade de se pensar o projeto do mobiliário adequado às proporções físicas das crianças.

Observou-se a presença de duas estantes próximas aos expositores da primeira infância que apresentam altura mais compatível com o público em questão. De fato, o expositor é mais eficaz no sentido de apresentar a capa dos livros frontalmente, facilitando o momento de escolha das crianças. 
- Os tatames

Notou-se que poucos alunos preferiram utilizar os tatames da Sala do Acervo Infantil para ler. Os que o fizeram, porém, sentaram e deitaram em diversas posições, ainda que brevemente e demonstraram estar a vontade neste revestimento do plano do piso. Da mesma forma, em todos os grupos observados, em dado momento, várias crianças usaram os tatames para brincadeiras, como luta, adoleta e pega-pega.

Este uso alternativo do tatame aponta para o fato de que a criança esta em constante contato com seu lado imaginativo e da brincadeira, o que lhes dá autonomia para brincar em qualquer lugar. a incluindo a biblioteca, indicio de um espaço onde são livres para brincar e explorar sua imaginação, para socializar com seus amigos e para se divertirem.

- As poltronas

A sala conta com duas poltronas de couro marrons, que foram utilizadas por várias crianças durante a leitura livre. Houve momentos em que as crianças brigaram por querer usar as poltronas, e houve crianças que compartilharam o assento, Chegou-se a observar crianças que deitaram na poltrona para ler e ali dormiram. Este mobiliário é o assento mais confortável deste espaço, mas são só dois exemplares dos mesmo, sendo que ambas razões que podem ter atenuado a disputa entre as crianças para utilizá-las.

- Mesas e cadeiras infantis

Os dois conjuntos de mesas e cadeiras infantis presentes não são da mesma linha de móveis ou têm características formais e estéticas una e compatíveis entre si. Observou-se em todos os grupos que as crianças corriam primeiro em direção à mesa colorida disputando as cadeiras pelas cores. Este fato pode apontar para a importância do desenho do mobiliário infantil levando-se em consideração também aspectos lúdicos, como as cores e o formato destes móveis.

Em relação à usabilidade, estes móveis não apresentaram problemas para as crianças mais novas, porém observou-se que as na faixa dos oito e nove anos tiveram problemas para utilizar as cadeiras infantis, pois alguns deles já tinham 
medidas físico corporais incompatíveis com a altura da mesa, gerando situações desconfortáveis

- Puffs

O ambiente dispõe de oito puffs de diferentes tamanhos, cores e revestimentos. Concluiu-se, a partir das observações à atividade, que este era o assento menos procurado pelas crianças. Algumas professoras sentavam nos puffs para interagir com as crianças, o que em alguns momentos estimulou o uso do objeto pelos alunos. No entanto, observou-se que ao invés de utilizá-lo enquanto assento, as crianças preferiam sentar no chão e apoiar o livro no puff, levando a apontar para a capacidade que as crianças têm em se apropriar dos objetos da forma que melhor convém para realização de suas atividades.

É importante ressaltar que este uso alternativo do puff como suporte para o livro não aconteceu por esta ser a única alternativa das crianças em questão de lugares para apoiar o livro: havia lugares livres nas mesas infantis, se esta fosse a necessidade que gerou a alternativa encontrada por estes alunos.

\section{2 - Relacionamento com os colegas e professores}

Notou-se, em todos os grupos observados, que a maioria das crianças preferia realizar a atividade em conjunto com seus colegas ou com as professoras que os acompanhavam. A escolha dos livros nas prateleiras e nas estantes foi o momento em que as crianças mais colaboravam e interagiam entre si. Muitas, principalmente na faixa etária de seis e sete anos, dividam o mesmo livro ou pediam para uma professora acompanhá-las na leitura dos livros. A troca de informações sobre as histórias também foi observada, muitas crianças liam umas para as outras as histórias.

É importante apontar que este tipo de observação realça a afirmação da biblioteca enquanto espaço de socialização e de união entre as crianças, fator formador de caráter e de cidadania.

3 - Conforto físico

Não foi observada, durante a atividade, nenhuma reclamação das crianças 
em relação à temperatura do local e nem à acústica ou iluminação.

No entanto, em alguns grupos, foi verbalizado por algumas crianças maiores o desconforto físico em relação ao uso das cadeiras e mesas infantis.

Sobre o uso dos tatames para leitura livre, também foi verbalizado por algumas crianças a vontade de que houvesse apoio para a cabeça, quando liam deitados.

4 - Interação com a atividade

As observações realizadas com os seis grupos de estudantes levam a concluir que os alunos estavam imersos na atividade de leitura livre, aparentando felicidade e satisfação em estar realizando a atividade. Devido s diferentes idades observadas, a realização da atividade teve suas peculiaridades em cada caso. Crianças de seis e sete anos, por exemplo, tiveram tendência a folhear os livros mais rapidamente, em observar as imagens e inventar histórias que não eram necessariamente as que estavam no livro, estas crianças se distraiam mais rápido e se movimentavam mais rapidamente, manipulando um maior número de livros. As crianças de oito e nove anos se mostraram mais focadas e seletivas na escolha dos títulos, passavam mais tempo com o mesmo livro, apesar de também demonstrarem interessem em explorar o máximo possível do acervo.

Atividades como o passeio à Biblioteca Monteiro Lobato são de suma importância para a vida cultural da criança, principalmente crianças moradoras de áreas periféricas da cidade, que não teriam a oportunidade de realizar este tipo de atividade que extrapola a função da leitura; instiga a criança a querer voltar; aumenta seu repertório de conhecimento e apropriação de espaços públicos e do cuidado com estes ambientes. Neste aspecto a relação entre escola e biblioteca publica é fundamental.

\subsubsection{3 - Observação das crianças com seus responsáveis}

Da mesma forma que nos procedimentos já descritos, a observação não -participante foi usada para coletar dados sobre como crianças, acompanhadas de adultos e não em grupos escolares, se apropriavam dos dois espaços. Foram realizadas entre os meses de agosto e outubro de 2016 usando como instrumenos apenas anotações e esboços de croquis, devido à restrição de registro de ima- 
gem das crianças que visitam a instituição para resguardar a privacidade do usuário. Buscou-se coletar dados que colaborassem para a compreensão de como a criança interage espaços e com seus equipamentos, mobiliários e com outros agentes envolvidos nesta dinâmica.

Durante as observações, a pesquisadora não entrou em contato com os usuários observados, buscando deixar a criança o mais confortável possível para atuar no ambiente sem que notasse que estava sendo observada. Quando os usuários estavam se dirigindo para fora da biblioteca, a pesquisadora abordou os adultos para perguntar a idade das crianças que os acompanhavam e aplicar o questionário presente no tópico 6.4 deste capítulo.

No total, foram validadas as observações de dez crianças na faixa etária entre seis e nove anos, que geraram dados de interesse a esta pesquisa. O quadro a seguir adianta os dados acerca das crianças observadas, bem como as atividades realizadas por elas:

\begin{tabular}{|c|c|c|c|c|}
\hline QUADRO 13 - DADOS SOBRE AS CRIANÇAS OBSERVADAS \\
\hline Criança & Idade & $\begin{array}{c}\text { Quantidade de } \\
\text { adultos }\end{array}$ & $\begin{array}{c}\text { Quantidade de } \\
\text { crianças }\end{array}$ & $\begin{array}{c}\text { Tempo de obser- } \\
\text { vação }\end{array}$ \\
\hline A & 8 & 2 & 3 & $40 \mathrm{~min}$ \\
\hline B & 6 & 2 & 3 & $40 \mathrm{~min}$ \\
\hline C & 6 & 2 & 3 & $40 \mathrm{~min}$ \\
\hline D & 7 & 1 & 1 & $20 \mathrm{~min}$ \\
\hline E & 8 & 1 & 3 & $25 \mathrm{~min}$ \\
\hline F & 6 & 2 & 3 & $30 \mathrm{~min}$ \\
\hline G & 9 & 2 & 3 & $30 \mathrm{~min}$ \\
\hline$H$ & 9 & 1 & 1 & $20 \mathrm{~min}$ \\
\hline I & 8 & 1 & 2 & $25 \mathrm{~min}$ \\
\hline J & 9 & 1 & 2 & $25 \mathrm{~min}$ \\
\hline
\end{tabular}

Fonte: Autora

A quantidade de adultos se refere ao número de adultos que os acompanharam durante a visita. A quantidade de crianças se refere ao número de crianças que foram juntas à Sala do Acervo, acompanhadas dos meus adultos. As cores utilizadas na tabela são para indicar as crianças que estavam juntas durante as observações.

Após a coleta e análise dos dados, foi possível estabelecer as seguintes categorias de aspectos obtidos, sobre as quais será discorrido: 


\section{QUADRO 14 - ASPECTOS OBTIDOS DURANTE A OBSERVAÇÃO}

1 - Relação com o acervo

2 - Interação com outras pessoas

3 - Interação com mobiliários e equipamentos

Fonte: Autora

1- Relação com o acervo:

- Notou-se que as crianças exploraram o acervo em diversas estantes, principalmente as dos expositores. As escolhas foram, em sua maioria, aleatórias. Apenas a criança "G" perguntou à funcionária da Sala sobre um título específico.

- As crianças "B" e "C", ambas com seis anos, preferiram ouvir as histórias narradas pelos adultos que as acompanhavam. Acredita-se que o fato se deu devido à idade, o que indica que ainda estão em fase de letramento.

- Todas as crianças observadas que foram à biblioteca em companhia de outras crianças, em algum momento compartilharam da leitura do mesmo livro.

- As crianças de nove anos passaram a maior parte do tempo lendo isoladas.

- Nenhuma das crianças observadas devolveu livros que pudessem ter levado emprestados durante a observação.

- Das crianças observadas, apenas a criança "H" retirou livros em sistema de empréstimo durante a observação.

Os dados acima apontam para o fato que apesar da diferença de idade entre as crianças não ultrapassar três anos, a relação desta com a leitura é distinta, pois as mais novas ainda são mais dependentes de adultos para ajudar com a leitura das história, enquanto que os mais velhos, por serem independentes, preferem ler sozinhos. No entanto, conforme previamente mencionado, todas as crianças, em dado momento, interagiram entre si, quando acompanhadas, o que aponta para o fator da socialização que a biblioteca infantil proporciona. 
Destaca-se que de todas as crianças observadas, apenas uma levou um livro emprestado, dando margem para o debate sobre a baixa incidência de uso do sistema de empréstimo nas bibliotecas públicas pelos usuários.

2 - Interação com outras pessoas:

- Todas as crianças que foram à Sala do Acervo acompanhadas de outras crianças, em um dado momento, interagiram entre si, na leitura dos livros ou brincando.

- Todas as crianças observadas tiveram algum momento de interação lúdica com os adultos responsáveis, ainda que fosse apenas para comentar sobre o livro que estava folheando. As crianças "B", "C", "D" e "H" ouviram histórias contadas pelos adultos que as acompanhavam.

- Durante todas as observações havia outras crianças ou bebês presentes na Sala do Acervo. Apenas as crianças "D", "E" e "H" não interagiram com crianças desconhecidas.

3 - Interação com os mobiliários e equipamentos

- As crianças buscavam geralmente sentar-se nas cadeiras coloridas para realizar a leitura individual;

- Não foram observadas dificuldades por parte das crianças em alcançar os livros nos expositores vermelhos.

- Algumas crianças aparentaram apresentar dificuldade em mover as cadeiras coloridas, devido ao peso;

- Crianças de oito e nove anos não aparentavam conforto ao sentar nas cadeiras brancas, pois era muito pequenas para sua altura;

- Para ler com os adultos, as crianças se dirigiam ao tatame, enquanto que para ler com outras crianças, estas se sentavam à mesa. 
Percebeu-se que, apesar da inadequação das mesas e cadeiras para as crianças maiores, estas ainda tentaram utilizar os mobiliários para interagir com as outras crianças. Além disso, o fato de que elas automaticamente separavam momentos com adultos no tatame e com crianças nas mesas infantis, leva a entender que existe, por parte das crianças, uma noção, ainda que intrínseca, de que o espaço está organizado de forma que seja ocupado em suas diferentes regiões de acordo com o usuário em questão.

Os tópicos acima descritos servem para ressaltar a importância da biblioteca pública infantil enquanto espaço propício para a socialização entre crianças de diversas faixas etárias, pois é neste tipo de ambiente que elas podem trocar experiências e se relacionar com crianças desconhecidas, de procedências que podem ser distintas ou semelhantes à sua. Foi observado crianças brincando e se relacionando não necessariamente com o acervo, ressaltando as múltiplas possibilidades do papel da biblioteca infantil para a formação, e a cultura do cidadão.

\subsubsection{4 - Questionário com os responsáveis}

Foram abordados 58 adultos que passaram pela Sala do Acervo Infantil e da Primeira Infância da Monteiro Lobato, entre os meses de agosto a outubro de 2016. Destes, concluiu-se que apenas 47 questionários estavam aptos para fornecer respostas com qualidade para o estudo, descartando-se os demais. Adianta-se que alguns dos responsáveis estavam acompanhados de crianças um pouco mais velhas ou mais novas que as da faixa etária pertinente a esta pesquisa, que foram considerados como respondentes captando dados de uso da biblioteca pública infantil. No entanto, no espaço reservado para a opinião da criança acerca deste ambiente, foram menosprezados os dados colhidos com crianças fora da faixa etária pertinente ao estudo.

O quadro a seguir aponta a quantidade de crianças entre seis e nove anos que acompanharam estes adultos à Sala do Acervo Infantil, divididos por idade: 


\begin{tabular}{|c|c|}
\hline QUADRO 15 - DADOS SOBRE AS CRIANÇAS OBSERVADAS \\
\hline Idade das crianças & Quantidade de crianças \\
\hline 6 anos & 16 crianças \\
\hline 7 anos & 6 crianças \\
\hline 8 anos & 8 crianças \\
\hline 9 anos & 12 crianças \\
\hline
\end{tabular}

Fonte: Autora

O quadro a seguir reúne as respostas acerca da frequência das visitas feitas pelas crianças:

\begin{tabular}{|c|c|}
\hline QUADRO 16 - FREQUÊNCIA DAS VISITAS DAS CRIANÇAS À BIBLIOTECA \\
\hline Frequência & Quantidade de respostas \\
\hline primeira vez & 12 \\
\hline semanalmente & 9 \\
\hline mensalmente & 4 \\
\hline a cada dois meses & 2 \\
\hline anualmente & 5 \\
\hline com frequência & 10 \\
\hline sempre que pode & 5 \\
\hline
\end{tabular}

Fonte: Autora

Apesar da essência qualitativa deste estudo os dados quantitativos acerca da frequência das crianças à biblioteca em questão indicam algumas recorrências significativas. Mesmo frisando que estes dados foram coletados aos finais de semana, pode-se inferir que das 47 respostas adquiridas, 12 pais estavam levando as crianças pela primeira vez à Monteiro Lobato. Considerando-se que nenhum deles era turista e todos habitantes da cidade de São Paulo, este número representa em torno de $25 \%$ dos entrevistados, apontando para um possível desinteresse ou desconhecimento por parte destes adultos da existência ou das possibilidades culturais da biblioteca para o público infantil.

No entanto, das 47 respostas, 21 pessoas afirmaram que as crianças a frequentam semanalmente, mensalmente ou com frequência, número que se aproxima da metade das respostas adquiridas. Assim, pode-se afirmar que existe um público fiel à biblioteca, que vê aquele local como uma possibilidade de passeio e entretenimento para as crianças.

Uma das perguntas que visava investigar a motivação do adulto para levar 
as crianças à Monteiro Lobato teve as seguintes respostas, expostas no quadro a seguir:

\begin{tabular}{|c|c|}
\hline QUADRO 17 - MOTIVOS PARA VISITAR A BIBLIOTECA \\
\hline Resposta & Quantidade de respostas \\
\hline Porque as crianças pedem & 12 \\
\hline Porque moramos perto & 5 \\
\hline Porque é um passeio gratuito & 4 \\
\hline Por causa do acervo & 10 \\
\hline Para realizar pesquisa escolar & 2 \\
\hline Porque ler ajuda no desempenho escolar & 3 \\
\hline Porque nós (os pais) pedimos & 5 \\
\hline Por acaso & 5 \\
\hline Por motivos de lazer & 6 \\
\hline Para conhecer a biblioteca & 4 \\
\hline \hline
\end{tabular}

Fonte: Autora

As respostas desta e das tabelas seguintes, não são excludentes entre si, significando que algumas pessoas deram mais de uma alternativa para a pergunta, por isso a somatória de respostas ultrapassa o número de entrevistados, considerando que algumas respostas se combinam entre si.

Desta forma, percebe-se uma grande quantidade de fatores positivos que motivam adultos a levarem as crianças à biblioteca. Doze pessoas responderam que as próprias crianças pedem para visitar a Monteiro Lobato, apontando para o fato de que gostam de frequentar a biblioteca. Respostas como "por motivos de lazer", "porque é um passeio gratuito" refletem para a característica de entretenimento podendo indicar também possibilidades lúdicas. Já a resposta "para conhecer a biblioteca que é famosa" resgata a importância da Biblioteca Monteiro Lobato em particular como símbolo para a cultura infantil na cidade de São Paulo. Dez pessoas citaram o acervo como razão para visitar a Monteiro Lobato, o que também reforça a importância desta biblioteca pela qualidade e quantidade de livros literários voltados para o público infantil e sua contribuição para a formação intelectual da criança.

Para os adultos, foi ainda perguntado o que eles mais gostavam em relação à Sala do Acervo Infantil e da Primeira Infância da Biblioteca Monteiro Lobato. O quadro a seguir reúne o conjunto de respostas similares: 


\begin{tabular}{|c|c|c||}
\hline QUADRO 18 - O QUE OS ADULTOS MAIS GOSTAVAM EM RELAÇÃO À SALA DO ACERVO \\
\hline Classificação & Resposta & Quantidade \\
\hline acervo & diversidade de livros & 17 \\
\hline \multirow{3}{*}{ mobiliário } & expositores de livros & 8 \\
\cline { 2 - 3 } & as poltronas marrons & 6 \\
\cline { 2 - 3 } & poder usar o tatame com os filhos & 6 \\
\cline { 2 - 3 } & quantidade de cadeiras para crianças & 2 \\
\hline espaço físico & espaço grande que permite socializar & 6 \\
\hline aspectos de caráter decorativo & a decoração & 2 \\
\hline atividades & a contação de histórias & 2 \\
\hline
\end{tabular}

Fonte: Autora

As respostas apresentadas apontam para uma visão utilitária do espaço pelos adultos, de poder usufruir destes ambientes como as crianças.

A diversidade do acervo foi mencionada por 17 pessoas quando levantaram os aspectos positivos referentes a esta sala.

Sobre o mobiliário presente, foram mencionados positivamente as poltronas marrons, por serem confortáveis e os expositores de livros porque facilitam a identificação das obras pelas próprias crianças, dando-Ihes mais independência no local. As pessoas que se referiram às cadeiras infantis da Sala, não verbalizaram o gosto pelas características da aparência (cor, materiais, desenho, estilo etc) ou pelo aparente conforto, apenas mencionando a quantidade, representando a importância de terem onde sentar para realizar as atividades, sem mencionar se estes assentos são apropriados para as crianças. Por fim, os tatames disponíveis para as crianças e seus acompanhantes utilizarem durante a leitura de livros ou para brincadeiras foi citado devido ao seu significado simbólico, pois é possível, estar próximo à criança neste momento. Não foram feitos elogios relativos ao tatame devido ao seu material, formato ou conforto, o que reafirma o valor simbólico implícito na afirmação.

Os entrevistados que mencionaram o espaço físico da Sala do Acervo Infantil como um ponto positivo justificaram suas respostas afirmando que o espaço possui muita área livre para que as crianças possam brincar e mobiliários distintos para leitura (tatame e mesas), o que torna o ambiente um espaço de múltiplas possibilidades. Também permite que as crianças conheçam outras crianças e so- 
cializem entre si (afirmação também extraída de citação dos entrevistados).

Apenas duas pessoas mencionaram aspectos referentes a objetos decorativos, sendo estas respostas referentes aos bonecos gigantes que representam os personagens do Sítio do Pica-Pau Amarelo, mas que não se localizam nesta sala.

Sobre a atividade de contação de histórias, os respondentes manifestam conhecimento prévio ou experiência anterior indicando positivamente esta possibilidade de usufruto. É relevante apontar para a importância de se abarcar atividades lúdicas à programação das bibliotecas infantis, especialmente às públicas, para potencializar o seu caráter educador, lúdico e informacional. Devido ao corte de verbas e mudanças nas gestões municipais, atividades semelhantes à esta foram e estão sendo cada vez mais diminuídas da programação da Monteiro Lobato, o que encadeia para um retrocesso na qualidade deste órgão.

A última pergunta feita aos adultos neste questionário buscou coletar informações acerca dos incômodos mais óbvios que o ambiente da Sala de Acervo ou seus equipamentos pudessem causar. O quadro a seguir compila as respostas dadas, divididas em temas para melhor compreensão didática:

\begin{tabular}{|c|c|c|}
\hline QUADRO 19 - INCÔMODOS DOS ADULTOS ACERCA DA SALA DO ACERVO \\
\hline Classificação & Resposta & Quantidade \\
\hline layout do ambiente & espaço reservado para bebês & 5 \\
\hline \multirow{3}{*}{ acervo } & sistema de renovação do acervo & 8 \\
\cline { 2 - 3 } & proibição de consulta do acervo pelas & 10 \\
\hline \multirow{4}{*}{ mobiliários e equipamentos } & criancas & 15 \\
\cline { 2 - 3 } & estante dos livros infantis & 6 \\
\cline { 2 - 3 } & pisar no tatame calçado & 4 \\
\cline { 2 - 3 } & falta de apoio para a coluna & 5 \\
\cline { 2 - 3 } & poucas poltronas & 10 \\
\cline { 2 - 3 } & cadeiras infantis & 2 \\
\hline \multirow{2}{*}{ estrutura do ambiente } & tomada para carregar eletrônicos & 2 \\
\cline { 2 - 3 } & muito frio no inverno & \\
\hline
\end{tabular}

Fonte: Autora

Sobre a organização espacial da Sala do Acervo Infantil, a única observação feita pelos adultos é que deveria haver um espaço reservado para crianças muito pequenas porque atualmente os bebês e as crianças muito pequenas divi- 
dem o espaço com as crianças maiores e estas ficam impedidas de brincar ou de correr, com receio de machucar as crianças menores. Além disso, os adultos (pais dos bebês) ressaltaram que apesar do lado positivo, que é o de poder estar com os filhos mais velhos e os bebês no mesmo ambiente, existe a preocupação com a segurança das crianças menores, pois estas podem se desequilibrar próximo a algum móvel com quinas pontudas e se acidentarem.

Sobre o acervo, a insatisfação dos adultos está relacionada primeiramente à logística de renovação do acervo, que deve ser feita presencialmente, o que às vezes se torna um transtorno para os responsáveis pela devolução dos livros. Em segundo lugar, foi mencionado por um número considerável de adultos a proibição por parte dos funcionários que as crianças acessem todas as estantes (como as que se localizam mais ao fundo da sala), restringindo a oferta as mais próximas às mesas e aos tatames. Esta proibição se dá pela falta de estrutura para organização do mesmo, pois as estantes que comportam este acervo específico não permitem, devido a altura e posição o manuseio por parte das crianças, o que acaba por prejudicar o trabalho da bibliotecária.

Quanto à aparencia, alguns usaram os termos "improvisada", "feia" e "comum" para falar sobre as estantes. Além disso, uma pessoa mencionou achar que estas estantes "não parecem fazer parte dessa sala, não tem nada a ver, não são infantis".

Sobre o tatame, as reclamações estão relacionadas ao fato de não haver almofadas ou puffs que ajudem a apoiar a coluna ou a cabeça enquanto lêem. Além disso, alguns responsáveis verbalizaram o problema relacionado à saúde porque todos pisam no tatame calçados e muitas crianças e bebês encostam o rosto ou a boca nele, o que pode causar doenças ou alergias.

Os adultos também mencionaram que deveria haver mais poltronas na sala, pois as consideram confortáveis tanto para as crianças quanto para eles próprios. Além disso, mencionaram notar que para crianças um pouco maiores, acima dos sete anos, as cadeiras infantis que fazem parte da Sala do Acervo Infantil já não são satisfatórias

Nenhuma adulto mencionou problemas relacionados à acústica ou à iluminação, porém duas pessoas alegaram que, durante o inverno, este ambiente 
fica muito frio e que não há calefação ou aquecedor para resolver o problema. O único outro problema relacionado à estrutura do prédio diz respeito à falta de tomadas para que os adultos possam carregar seus telefones e tablets enquanto estão no ambiente, mas uma das pessoas mencionou compreender que é mais seguro para as crianças que não fiquem expostas à eletricidade.

Algumas das crianças que estavam acompanhadas pelos adultos que responderam ao questionário, se propuseram a responder à pergunta "De que você mais gosta nesta sala da biblioteca?" As respostas das crianças foram analisadas e compiladas na tabela a seguir, divididas em temas semelhantes:

\begin{tabular}{|c|c|c||}
\hline \multicolumn{2}{|l||}{ QUADRO 20 - PREFERÊNCIA DAS CRIANÇAS ACERCA DA SALA DO ACERVO INFANTIL } \\
\hline Classificação & Resposta & Quantidade \\
\hline generalizado & "eu gosto de tudo" & 5 \\
\hline acervo & dos livros e gibis & 8 \\
\hline \multirow{2}{*}{ atividade } & de brincar com meus amigos daqui & 10 \\
\cline { 2 - 3 } & de ler com meus pais & 15 \\
\cline { 2 - 3 } & de ler com meus irmãos & 6 \\
\hline \multirow{2}{*}{ mobiliário } & das mesas e cadeiras & 4 \\
\hline estrutura & de ler nas poltronas marrons & 5 \\
\hline
\end{tabular}

Fonte: Autora

Das 23 crianças que responderam à pergunta, 3 responderam que gostam de tudo e não quiseram discorrer sobre o assunto. Quase um terço das crianças citou o acervo como o que elas mais gostavam em relação à Monteiro Lobato. "Aqui tem muito livros legais, de muitos tipos. Eu posso ler quantos eu quiser e levar pra minha casa se eu quiser também."

"Essa biblioteca é muito grande, muito bonita. Os livros não acabam nunca, eu amo que tenha todos esses livros aqui."

Um terço das crianças também mencionou que o que elas mais gostam na sala é poder ler com outras pessoas (pais, irmãos ou novos amigos). É importante ressaltar o caráter de espaço socializador que a biblioteca infantil possui, reafirmado com falas como:

"Toda vez que eu venho aqui, eu faço um amiguinho novo, ou uma amiguinha nova. Teve vezes de eu fazer quatro, cinco amigos. A mãe deles leu uma historinha 
pra gente sobre os piratas, foi muito divertido, sabia?”

No que diz respeito a destaques no mobiliário da Sala do Acervo, as menções são feitas para a mesa quadrada com tampo colorido e suas cadeiras coloridas.

"Quando eu venho, sento sempre numa cadeira diferente, da cor que fica igual a ela na mesa, sabe? azul com azul, verde com verde. Quando eu troco de livro, eu escolho outra cor pra sentar, porque aí mudou a história, né?"

A fala acima, de uma das crianças, ressalta a importância da inserção de aspectos lúdicos no ambiente infantil, que motiva a criança a permanecer no local e a se sentir mais confortável naquele ambiente.

Além destes, o mobiliário citado por algumas crianças foi a poltrona marrom, pelas seguintes características:

"Ela é muito grande e fofinha e eu posso deitar nela e ler o quanto eu quiser." "Uma vez eu tava lendo uma historinha e dormi na poltrona, de tão fofinha que ela era."

"As cadeiras de criança são pequenas pra mim, eu fico com as minhas costas doendo e meu joelho bate na mesa. A poltrona é mais confortável."

Extraídos das falas das crianças, os comentários acima levam a entender que as mesas e cadeiras infantis presentes na Sala não servem para todas as crianças que frequentam o espaço; além disso, o quesito "conforto" foi mencionado pelas três crianças que citaram a poltrona, levando a inferir sobre a necessidade de mobiliários que permitam à criança outras possibilidades de se posicionar para a leitura, não apenas a tradicional forma de sentar na cadeira.

O último ponto extraído das respostas das crianças remete à fala de uma criança em particular, que afirma ser a contemplação da área verde externa o fator preferido em relação à Sala do Acervo. Apesar de ter sido mencionado por apenas uma criança, é válido levantar este aspecto de conexão da criança com a natureza enquanto forma de conforto e bem-estar, às vezes esquecido pelos projetistas de ambientes. 


\subsection{ESTUDO DE CASO 2 - COLÉGIO X}

Tendo como um dos escopos desta pesquisa crianças entre seis e nove anos, este Estudo de Caso trouxe a seguinte particularidade: no Colégio X, duas bibliotecas são importantes, pois os usuários de seis anos se encontram, em sua maioria, em um biblioteca, enquanto que os de sete a nove anos se encontram em outra biblioteca. Desta forma, foi necessário subdividir este Estudo de Caso em dois, onde consideramos cada uma destas bibliotecas particularmente. Desta forma, apesar de se tratar de uma única instituiç̧ão de ensino, serão analisadas duas bibliotecas que se assemelham em sua função e atividades, mas com usuários em idades diferentes apesar de próximas e com organização espacial e profissionais distintos entre si, com exceção da bibliotecária.

A imagem a seguir introduz a forma como o estudo de caso 2 foi dividido, de modo que informações pertinentes a ambos as bibliotecas não fossem repetidas. De forma geral, o que é pertinente a ambas as bibliotecas é apresentado primeiro, podendo ser consultado posteriormente caso necessário.

1 COLÉGIOX

apresentação

4

MÉTODOS E FERRAMENTAS

apresentação de cada um dos

métodos e ferramentas utilizados

no Estudo de Caso

Entrevista - bibliotecária contadora

Observações não-participantes

Storytelling - alunos

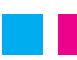

Legenda:

Informações pertinentes à

Biblioteca Alfa

Informações pertinentes à

Biblioteca Beta AULAS DE BIBLIOTECA
definição

5 BIBLIOTECA ALFA

Apresentação - o ambiente em 2015 e em 2016

RESULTADOS OBTIDOS

Entrevista - bibliotecária contadora

Observações não-participantes

Storytelling - alunos
3 STAKEHOLDER MAP

6 BIBLIOTECA BETA

Apresentação - o ambiente

RESULTADOS OBTIDOS

Entrevista - bibliotecária contadora

Observações não-participantes

Storytelling - alunos

Figura 47 - Representação gr'afica do desenvolvimento do estudo de caso.

Fonte:Autora 


\subsubsection{Sobre o Colégio $X$}

Localizado na zona sul da cidade de São Paulo, o Colégio X data da década de 1940 e, até a década de 1970, atendia apenas ao público feminino, vindo a se tornar uma escola mista em meados dessa década. Considerada uma das escolas mais tradicionais da cidade e referência em ensino em São Paulo, o Colégio atende a um público de classe social mais alta, considerando a definição dada pelo critério de renda. Trata-se de uma das maiores escolas em termos de espaço físico.

A escola se divide em três grandes conjuntos educativos, localizados na mesma rua. O primeiro é destinado a crianças do Jardim de Infância até o primeiro ano do Ensino Fundamental, onde se localiza a Biblioteca Alfa. O segundo conjunto está destinado aos alunos do segundo ao nono ano do Ensino Fundamental e abriga a chamada Biblioteca Beta, que atende aos alunos destas séries e aos alunos do Ensino Médio, sendo este ambiente e o anterior pesquisados neste estudo. O último conjunto da escola é voltado para os alunos do Ensino Médio, apenas para salas de aula.

Esta configuração da escola em conjuntos edificados de acordo com os níveis de ensino do infantil ao médio é recente. Até o final do ano de 2015, os alunos do segundo ano do Ensino Fundamental estavam alocados no mesmo conjunto que as crianças do Jardim de Infância A partir do início do ano letivo de 2016, no entanto, foram transferidos para a mesma localização territorial que os outros grupos do Ensino Fundamental.

A escola conta com uma estrutura física que abarca bibliotecas, salas de informática, quadras poliesportivas, sala de música, parque, sala de eventos, ginásio de esporte, auditório, dentre outras facilidades.

Este estudo de caso debruça-se na análise da participação dos alunos nas Salas de Contação de Histórias de ambas as bibliotecas da Escola X, por compreender-se que é neste ambiente especificamente que se concentra praticamente toda a atuação das crianças, em especial as Aulas de Biblioteca.

\subsubsection{Aulas de Biblioteca}

No Colégio $X$, esta atividade é quinzenal e obrigatória, constando na grade curri- 
cular das crianças do Ensino Infantil ao quinto ano do Ensino Fundamental. Elas são levadas em grupos (os mesmos em que assistem às aulas regulares) para a biblioteca e participam da atividade de Contação de Histórias, realizada por uma profissional cuja principal função na escola é a de ministrar as Aulas de Biblioteca.

Atualmente, a escola dispõe de três contadoras de história: uma para os alunos da Biblioteca Alfa, outra para os alunos do segundo ano do Ensino Fundamental, e a última para os alunos do terceiro ao quinto ano do Ensino Fundamental.

As aulas de biblioteca têm duração média de cinquenta minutos e são planejadas semestralmente pelas profissionais em conjunto com a bibliotecária, recebendo aprovação final da orientadora educacional de cada uma das séries. A atividade geralmente consiste de leitura e interpretação de alguma história previamente selecionada, seguida de atividades sobre o tema, com a participação efetiva das crianças.

As responsáveis pelas atividades se utilizam de diversas técnicas de contação de histórias, como leitura em voz alta, interpretação, fantoche, teatro de sombras, além de fazer uso de mídias como a projeção de imagens e vídeos.

É durante as aulas de biblioteca que a grande maioria dos alunos faz o empréstimo e a devolução do acervo e interage com o ambiente da biblioteca, apesar deste espaço estar aberto para todos os alunos durante o todo período de funcionamento da escola, quando não está sendo utilizado para aulas.

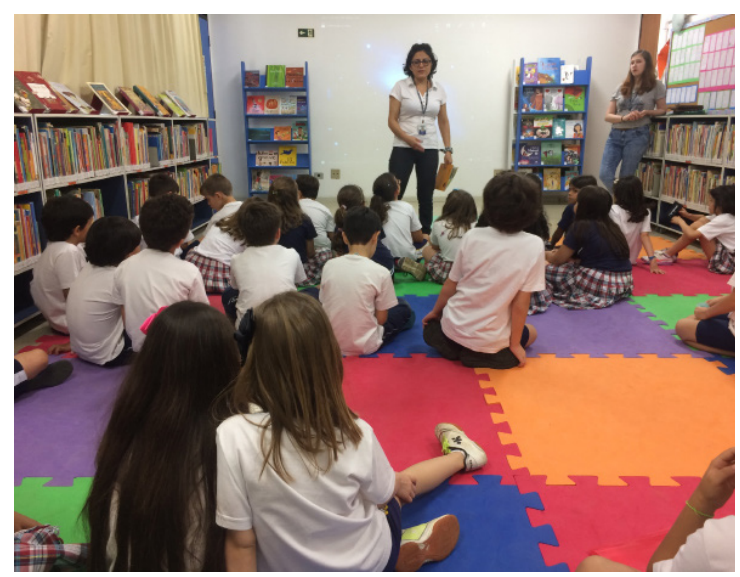

Figura 48 - Aula de biblioteca na Biblioteca Beta do Colégio X. (2016) Fonte:Autora 


\subsubsection{Stakeholder}

A representação gráfica a seguir define os Stakeholders de ambas as bibliotecas do Colégio $X$ :

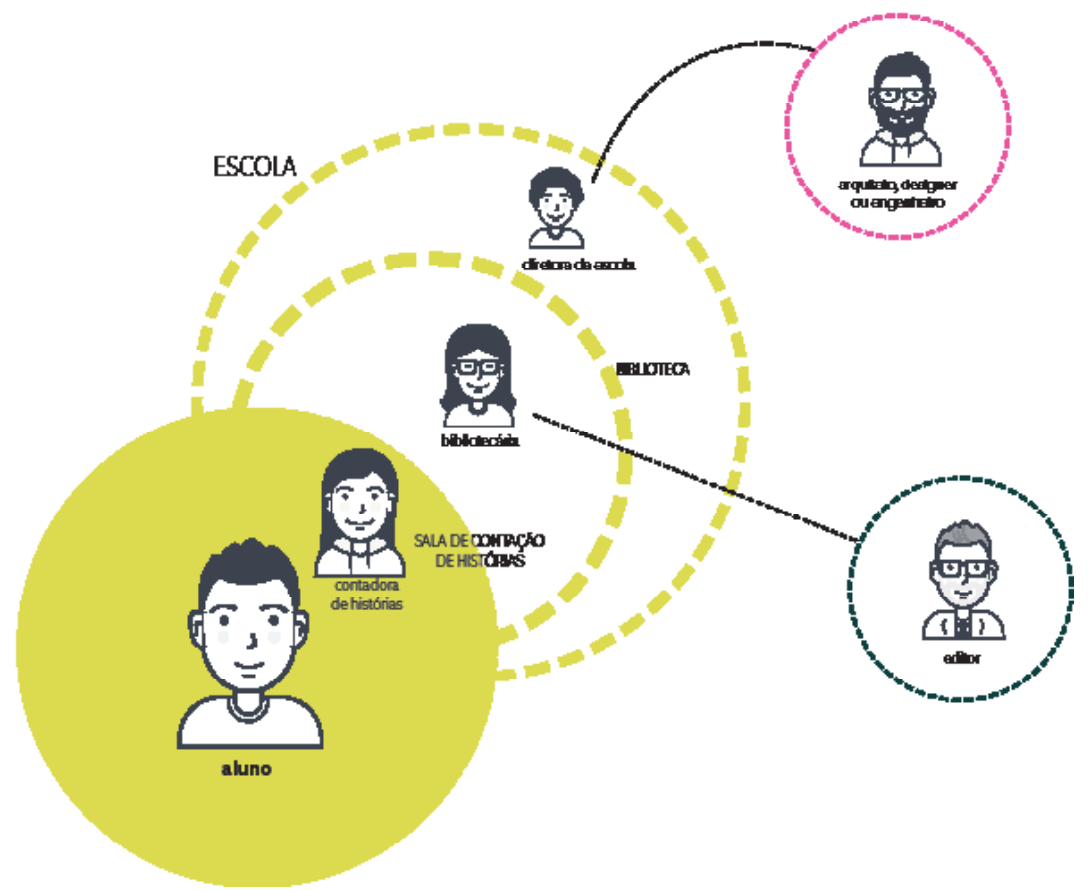

Figura 48 - Stakeholder para as bibliotecas Alfa e Beta. Fonte:Autora

Dos stakeholders apresentados na figura acima, os que não foram abordados neste estudo são: a diretora da escola, o editor e o profissional responsável pela organização do espaço físico da biblioteca.

A diretora da escola não foi incluída na pesquisa porque a bibliotecária supre as responsabilidades pedagógicas das bibliotecas em questão, porém o aval para que a pesquisadora pudesse avançar na pesquisa e obter os dados para a mesma sempre foi dado pela diretora da escola.

O editor é o stakeholder que representa a entrada do acervo na escola, todavia o aval para que os livros levados pelas editoras permaneça nas bibliotecas é dado pela bibliotecária então, para a pesquisa, este stakeholder não é relevante.

Quanto ao designer ou arquiteto, estes se encontram no stakeholder simbolizando o responsável pela organização espacial da biblioteca, porém no caso do Colégio X, a bibliotecária informa a necessidade da aquisição de novos equipamentos e a diretoria compra da indústria. Já os móveis feitos sob medida são pro- 
jetados pelo marceneiro da escola, não havendo então quem executasse o papel de designer ou de arquiteto neste caso.

Desta forma, os stakeholders explorados neste estudo de caso foram para ambas as bibliotecas: o aluno, a bibliotecária e as contadoras de história. Para gerar os dados necessários para a pesquisa foram aplicadas ferramentas específicas para cada um deles, que serão apresentados no subtópico a seguir.

\subsubsection{Métodos e Ferramentas}

As ferramentas foram aplicadas de forma distinta para os stakeholders, levando em consideração a melhor forma de se obter as informações desejadas. Para ambas as bibliotecas foram utilizadas as mesmas ferramentas com os stakeholders da mesma tipologia.

\subsubsection{1 - Entrevista com a bibliotecária}

A bibliotecária nesta escola é responsável pela gestão administrativa e pedagógica da biblioteca. É um stakeholder importante, pois suas funções impactam nas atividades realizadas pelos alunos na biblioteca, tanto nos aspectos pedagógicos (que levam em conta quais serão as atividades e como serão desenvolvidas) quanto os que dizem respeito ao ambiente físico da biblioteca, tendo autonomia para propor mudanças nos equipamentos, acervos e mobiliários da biblioteca.

Para compreender como a bibliotecária atua nesta biblioteca, foi feita uma entrevista individual semi-estruturada orientada por roteiro previamente elaborado, considerando a preparação das perguntas, agendamento da entrevista, realização da entrevista com anotações de apontamentos e gravação de áudio autorizada pela entrevistada, transcrição da gravação e análise dos dados obtidos.

Os temas abordaram aspectos relacionados ao espaço e ao funcionamento das atividades; percepções e praticas sobre o uso, a autonomia e manifestações positivas ou negativas dos alunos em relação à biblioteca.

\subsubsection{2 - Entrevista com as contadoras de histórias}

As contadoras de histórias atuam em contato direto com as crianças, sendo 
responsáveis por todas as atividades desta função, e também por estarem presentes em todos os momentos dos alunos na biblioteca.

O processo para realizar a entrevista de caráter individual e semi-estruturada com a contadora de histórias (também conhecida como professora de biblioteca) se deu de maneira similar à da bibliotecária.

Os aspectos abordados captaram as funções e atividades da profissional, o histórico pessoal na instituição; relato sobre o desenvolvimento das aulas e praticas com os alunos; percepção sobre a apropriação dos dispositivos, materiais, recursos e conteúdos pelos alunos; dados sobre a adequação ou mudanças sugeridas para o espaço.

\subsubsection{3 - Observação não participante das aulas}

O procedimento de observação não participante foi realizado nos meses de novembro e dezembro de 2015 e nos meses de outubro, novembro e dezembro de 2016.

Algumas das aulas de ambas as bibliotecas da escola ocorridas no ano letivo de 2015, através de anotações da pesquisadora como forma de registro das aulas. Em atenção às condições estabelecidas pela escola, somente foram executados registros textuais de fatos, ocorrências e procedimentos em aula, observando as crianças em atividades sem captura de imagens face a proibição em fotografar ou filmar as aulas. Posteriormente a esta ação, foi solicitada autorização à direção da escola a realização de registro fotográfico das aulas, preservando a identidade das crianças participantes, permitindo assim conferir aprofundamento e suporte as observações.

O procedimento das observações consistia na presença da pesquisadora durante as aulas de biblioteca, sentada no fundo da sala, em silêncio, sem participar das aulas e interagindo o mínimo possível com os alunos ou com as contadoras de histórias. Durante as aulas de biblioteca de 2015, a pesquisadora fez apontamentos acerca dos aspectos observados e fez croquis das posições em que os alunos se sentavam ou deitavam no tatame, buscando obter o máximo de informações a cada aula.

Em 2016, a possibilidade de fotografar as aulas, desde que se preservasse a identidade dos alunos, possibilitou colher mais dados e ter mais precisão em rela- 
ção ao comportamento do aluno, pois as fotografias reduziram significativamente o tempo que seria investido em croquis.

Buscou-se coletar com as observações aspectos referentes ao comportamentos dos alunos nas aulas de biblioteca, sua relação com os equipamentos e com os mobiliários ao seu redor, a forma como eles se posicionavam no ambiente, os sentimentos que externavam, a socialização entre si e como os objetos e a forma como o ambiente estava organizado parecia colaborar ou não para o andamento das atividades.

O quadro a seguir sintetizam numericamente no tempo, os registros das observações feitas em ambas as bibliotecas:

\begin{tabular}{|c|c|c|c|c|c|}
\hline \multicolumn{6}{|c|}{ QUADRO 21 - INFORMAÇÕES SOBRE OS REGISTROS DAS OBSERVAÇÕES REALIZADAS } \\
\hline Série & Grupo & Alunos & Ano & Contadora & Instrumentos \\
\hline \multirow{7}{*}{$1^{\circ}$ ano } & A & 9 & 2015 & \multirow{7}{*}{ Beth } & \multirow{4}{*}{$\begin{array}{l}\text { croquis e } \\
\text { anotações }\end{array}$} \\
\hline & $\mathrm{B}$ & 9 & 2015 & & \\
\hline & C & 10 & 2015 & & \\
\hline & D & 8 & 2015 & & \\
\hline & $\bar{E}$ & 12 & 2016 & & \multirow{3}{*}{$\begin{array}{c}\text { fotografias e } \\
\text { anotações }\end{array}$} \\
\hline & $\bar{F}$ & 9 & 2016 & & \\
\hline & $\bar{G}$ & 11 & 2016 & & \\
\hline \multirow{3}{*}{$2^{\circ}$ ano } & $\bar{H}$ & 30 & 2016 & \multirow{3}{*}{ Silmara } & \multirow{3}{*}{$\begin{array}{c}\text { fotografias e } \\
\text { anotações }\end{array}$} \\
\hline & I & 32 & 2016 & & \\
\hline & J & 31 & 2016 & & \\
\hline \multirow{4}{*}{$3^{\circ}$ ano } & K & 29 & 2015 & \multirow{7}{*}{ Cleuda } & $\begin{array}{l}\text { croquis e } \\
\text { anotações }\end{array}$ \\
\hline & $\mathrm{L}$ & 34 & 2016 & & \\
\hline & $M$ & 33 & 2016 & & $\underset{\sim}{\text { fotografias e }}$ \\
\hline & $\mathrm{N}$ & 29 & 2016 & & anotações \\
\hline \multirow{3}{*}{$4^{\circ}$ ano } & 0 & 31 & 2015 & & $\begin{array}{c}\text { croquis e } \\
\text { anotações }\end{array}$ \\
\hline & $P$ & 30 & 2016 & & \multirow{2}{*}{$\begin{array}{c}\text { fotografias e } \\
\text { anotações }\end{array}$} \\
\hline & $\bar{Q}$ & 32 & 2016 & & \\
\hline
\end{tabular}

Fonte: Autora 


\subsubsection{4 - Storytelling com os alunos}

Aplicados com crianças que frequentam ambas as bibliotecas, buscou-se realizá-lo com alunos de diferentes grupos nas turmas em questão. A frase norteadora do storytelling "Eu gostaria que a biblioteca da minha escola fosse assim" foi escolhida pelo potencial que apresenta para instigar nas crianças respostas com grande riqueza de informações para a pesquisa. No apêndice deste documento, é possível conferir o documento enviado para os responsáveis pelos alunos, indicando a forma como a atividade deveria ser conduzida.

As ferramentas apresentadas neste tópico foram aplicadas em ambas as bibliotecas do Colégio X. Os resultados obtidos após a análise dos dados colhidos serão apresentados nos tópicos a seguir, divididos por biblioteca. Por motivos didáticos, deixou-se para apresentar os ambientes das bibliotecas Alfa e Beta juntamente com os Resultados das análises.

\subsubsection{Biblioteca Alfa}

Esta biblioteca atende crianças do Ensino Infantil ao primeiro ano do Ensino Fundamental. Até o ano de 2015, os alunos de uma mesma turma assistiam às Aulas de Biblioteca divididos em dois grupos de aproximadamente quinze crianças cada, porque o espaço da biblioteca não comportava toda a turma de uma vez.

A imagem a seguir retrata a organização do ambiente até o final do ano letivo de 2015, antes da reforma que ampliou a Biblioteca Alfa e tornou este espaço apenas a Sala do Acervo.

Até então, um único ambiente comportava todas as atividades referentes à Biblioteca Alfa: empréstimo e devolução do acervo, contação de histórias e outras atividades pertinentes às aulas de biblioteca. 


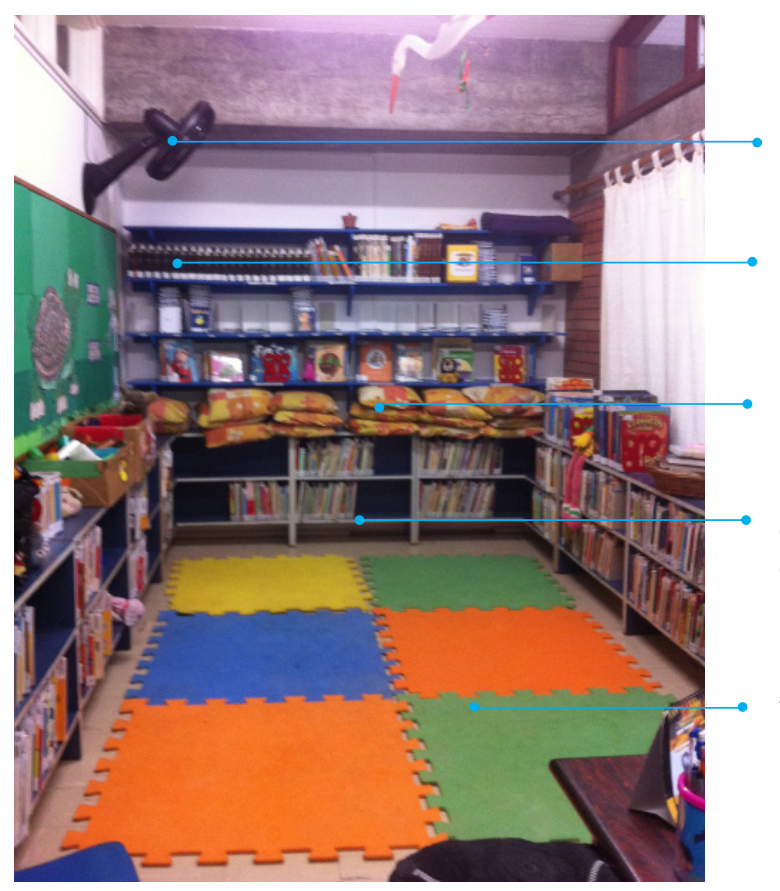

um dos ventiladores fixados à parede

prateleiras de madeira para guardar trabalhos dos alunos

almofadas para os alunos usarem durante as aulas

estantes de madeira com todo o acervo da Biblioteca Alfa

tatame onde os alunos realizam as atividades na biblioteca

Figura 49 - Biblioteca Alfa em 2015. Fonte:Autora

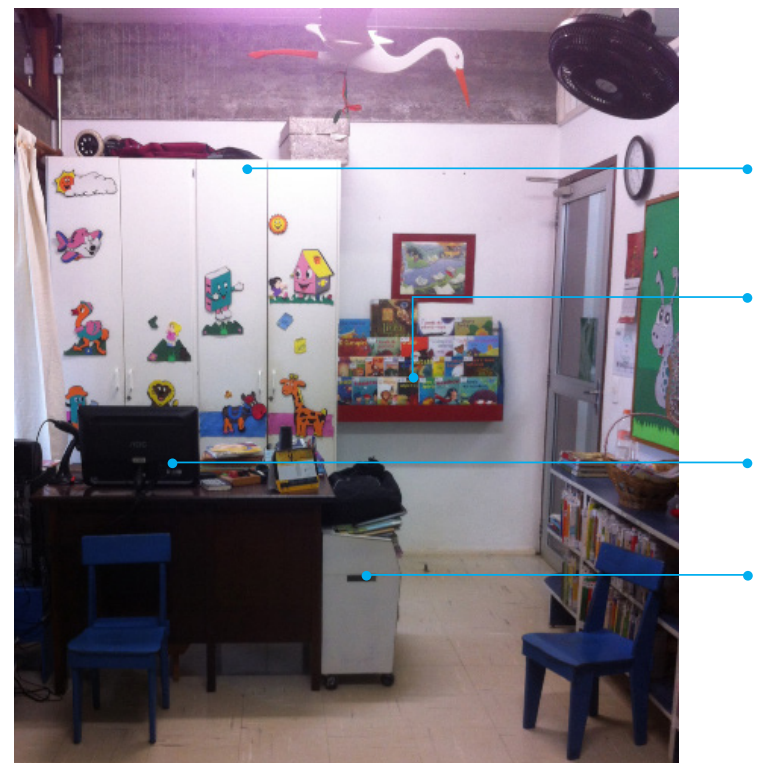

armário para uso das bibliotecárias

expositor para os alunos escolherem os livros para empréstimo

computador da biblioteca

carrinho para receber o acervo de empréstimo

Figura 50 - Biblioteca Alfa em 2015. Fonte:Autora 
QUADRO 22 - RELAÇÃO DE MOBILIÁRIOS E EQUIPAMENTOS DA BIBLIOTECA ALFA (2015)

\section{PARA USO INFANTIL}

- estantes de madeira que circundam 3 paredes da sala, dividindo o acervo de acordo com a série

- um expositor fixado na parede com 4 divisórias

- almofadas para uso durante as aulas de biblioteca

- caixas com bichos de pelúcia para uso durante as aulas de biblioteca

- tatame de e.v.a. constituído por 6 módulos de $1 \mathrm{~m} \times 1 \mathrm{~m}$

\section{PARA USO DE ADULTOS}

- um armário fechado de duas portas

- uma escrivaninha

- uma cadeira de escritório

- um computador de mesa

- quatro prateleiras azuis localizadas na parede do fundo da sala, para guardar projetos dos alunos

- um carrinho com rodízio para receber os livros que voltam de empréstimo

\section{OUTROS EQUIPAMENTOS}

- 2 ventiladores acoplados na parede

-1 mural informativo

Fonte: Autora

Até então, um único ambiente comportava todas as atividades referentes à Biblioteca Alfa: empréstimo e devolução do acervo, contação de histórias e outras atividades pertinentes às aulas de biblioteca.

Antes do início do ano letivo de 2016, esta biblioteca foi reformada e agora conta com dois ambientes distintos em suas funções: uma sala apenas para a contação de histórias e suas atividades, e outra sala onde fica o acervo e onde é realizado o empréstimo dos livros. As imagens a seguir retratam a atual Sala do Acervo da Biblioteca Alfa, que ocupa o mesmo espaço físico da antiga Biblioteca Alfa de 2015 e a nova Sala de Contação de Histórias, localizada em frente à Sala do Acervo. 


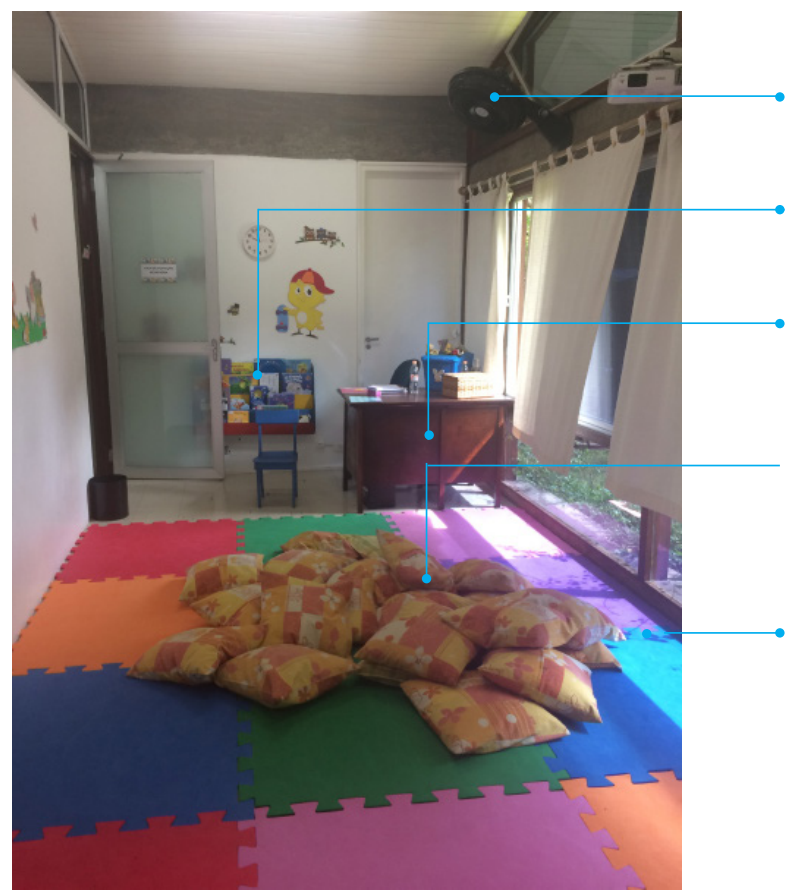

um dos ventiladores fixados na parede

expositor que ficava na biblioteca em 2015

escrivaninha da contadora

almofadas para os alunos usarem durante as aulas

tatame onde os alunos realizam as atividades na biblioteca

Figura 51 - Biblioteca Alfa em 2016 - Sala de Contação de Histórias

Fonte: Autora

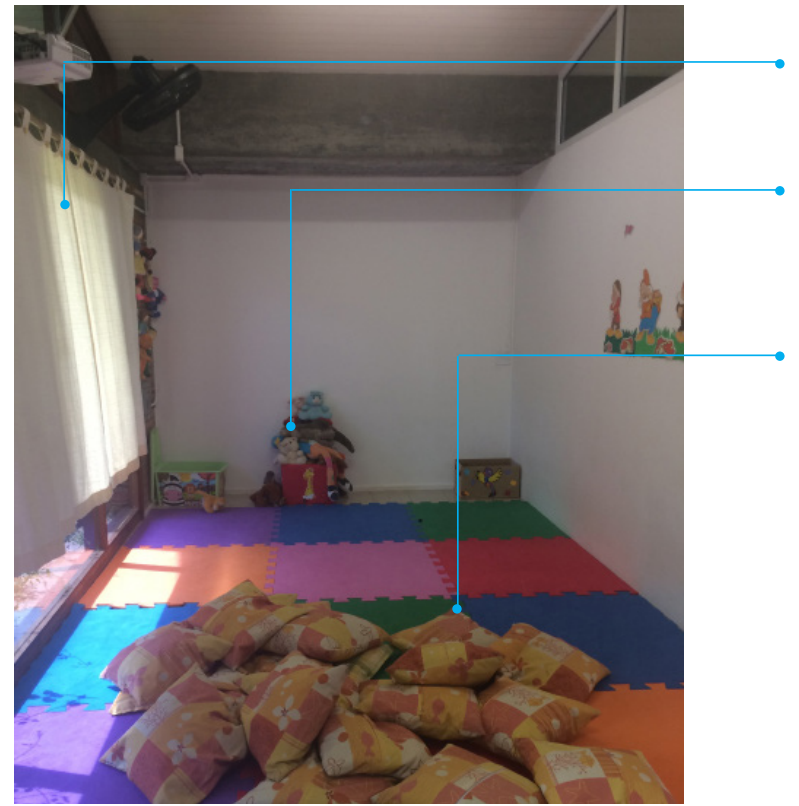

cortinas para bloqueio do sol durante as aulas

caixas que guardam as pelúcias e adereços para as aulas

almofadas utilizadas durante as atividades na sala

Figura 52 - Biblioteca Alfa em 2016 - Sala de Contação de Histórias

Fonte: Autora 


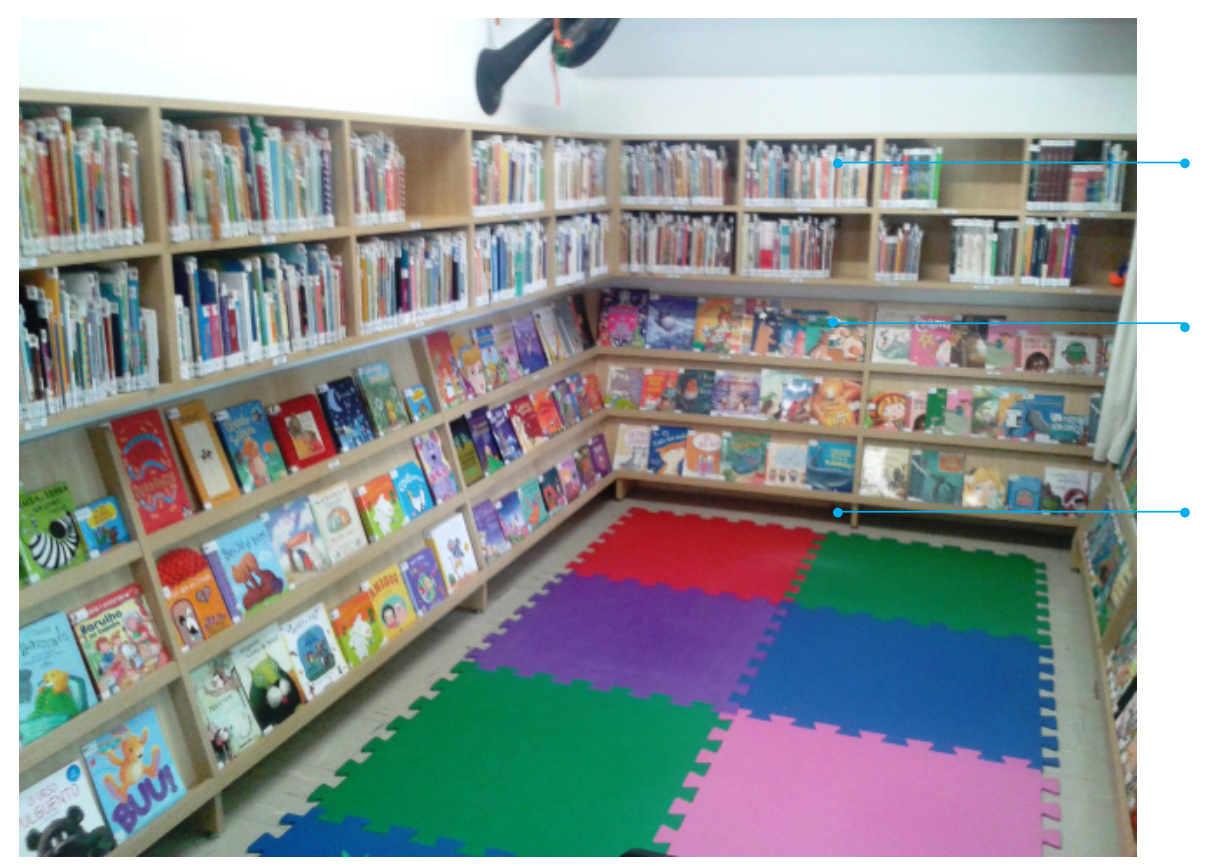

estantes com acervo propositalmente fora do alcance das crianças

expositores com o acervo para as crianças lerem na sala ou levarem em empréstimo

tatames em e.va. para as atividades realizadas na sala

Figura 53 - Biblioteca Alfa em 2016 - Sala do Acervo Fonte: Autora

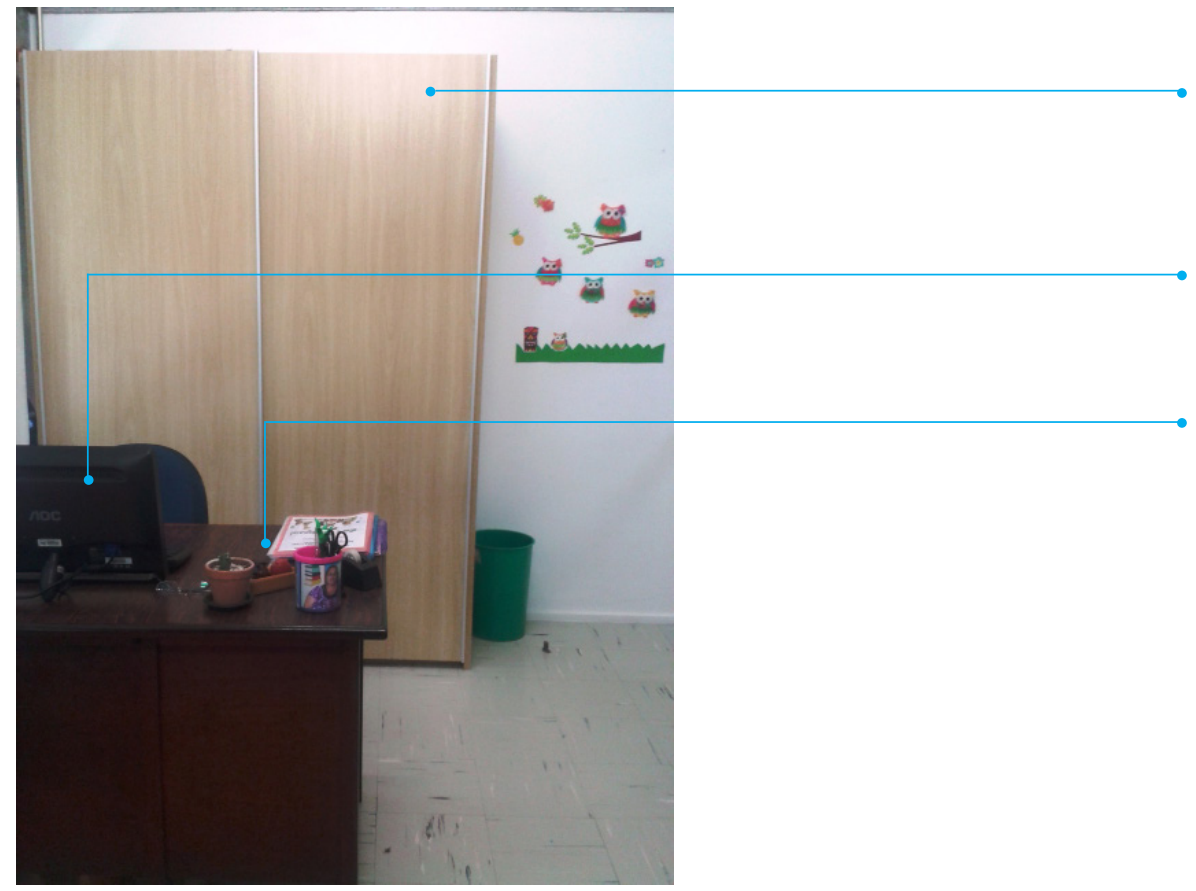

armário com portas corrediças para uso da bibliotecária

computador para uso da bibliotecária

escrivaninha da bibliotecária

Figura 54 - Biblioteca Alfa em 2016 - Sala do Acervo Fonte: Autora 
QUADRO 23 - RELAÇÃO DE MOBILIÁRIOS E EQUIPAMENTOS DA BIBLIOTECA ALFA (2016)

\section{SALA DO ACERVO}

\section{PARA USO INFANTIL}

- expositores de madeira para o acervo, que circundam três paredes da sala, com 3 prateleiras cada

- tatame de e.v.a. com oito módulos de $1 \mathrm{~m} \times 1 \mathrm{~m}$

\section{PARA USO DE ADULTOS}

- um armário fechado de duas portas corrediças

- uma escrivaninha

- uma cadeira de escritório

- um computador notebook

- prateleiras suspensas em duas paredes da sala, para guardar o acervo extra

\section{OUTROS EQUIPAMENTOS}

-2 ventiladores acoplados na parede

\section{SALA DE CONTAÇÃO}

\section{PARA USO INFANTIL}

- almofadas para uso durante as atividades

- tatame de e.v.a. com quinze módulos de $1 \mathrm{~m} \times 1 \mathrm{~m}$

- caixas com brinquedos e acessórios para uso durante as atividades

\section{PARA USO DE ADULTOS}

- uma escrivaninha

- uma cadeira de escritório

\section{OUTROS EQUIPAMENTOS}

- dois ventiladores acoplados na parede

- projetor para exibição de vídeos

Fonte: Autora

Com estas mudanças que ocorreram no espaço físico e nos mobiliários da

Biblioteca Alfa, entre 2015 e 2016, foi possível tecer análises mais profundas sobre como o ambiente influencia na relação do usuário com a biblioteca e seus componentes, devido à oportunidade de comparar a realização das aulas de biblioteca em duas estruturas diferentes para crianças da mesma idade.

\subsubsection{Resultados obtidos}

\subsubsection{1 - Entrevista com a bibliotecária}

Após transcrever na íntegra os áudios desta entrevista, foi possível anali- 
sá-lo, criando-se sub-categorias em decorrência da existência de perguntas com temas semelhantes. Considerando-se que o papel da bibliotecária nesta biblioteca é diferente do das contadoras de história, não foi possível haver comparação das respostas às perguntas com as das outras profissionais.

\subsection{1 - Relação Bibliotecária e Ambiente}

Dentre as funções da bibliotecária, destaca-se a possibilidade de propor mudanças e intervenções nos ambientes e nos equipamentos da biblioteca. Os trechos a seguir enfatizam a preocupação da bibliotecária em melhorar as aulas, bem como sua autonomia para promover mudanças. Quando questionada acerca da futura divisão de salas da Biblioteca Alfa, a profissional responde:

"...a gente ficou com duas salas, eu logo pensei "então faço uma sala só de contação, que aí não vai ter móveis e eu consigo colocar todos os alunos juntos pra ouvirem a história juntos...Coloco o tatame no chão, pra ficar gostoso pra eles sentarem, almofada. Vai ter um projetor, se a gente precisar projetar alguma coisa na parede. E tem espaço na frente pra gente usar fantoche, um teatrinho. Vou comprar também fantasias novas, bichinho de pelúcia que a gente usa também pra contação."

Além de pensar uma logística de ambientes divididos a partir das atividades exercidas neles, a bibliotecária também enxergou a necessidade de modificar as estantes da sala na época.

"Agora eu quero fazer também embaixo só ambiente de expositor, pra eles conseguirem visualizar melhor o livro e escolher por si só, porque as vezes eles ficam muito...é...preso e dependentes das nossas indicações. Porque no formato que tá hoje, eles não conseguem circular e pegar os livros na estantes, eles só conseguem ir num expositor que a gente tem e pegar de lá, que é onde indica. Agora, se eu tiver mais expositores, eu consigo indicar mais coisas, e eles conseguem sozinhos chegar na estante e escolher... você deixa o aluno...qual que é a palavra? Independente!”

É possível notar, portanto, que a profissional enxerga a importância de um 
ambiente bem aproveitado e bem projetado, para que as atividades se desenvolvam com o maior potencial possível.

Ainda sobre o ambiente da Biblioteca Alfa e os artefatos que a compõem, quando questionada acerca de possíveis desconfortos físicos proporcionados pelo ambiente e seus artefatos que pudessem estar incomodando as crianças durante as atividades, a bibliotecária afirma que:

"Sim (ocorria), as perninhas deles não cabiam de to dos dentro do tatame... Equanto ao acervo, que é que acontece, como eles não podiam mexer, eles queriam mexer. Então eles ficavam pegando (no acervo) fora de hora. Não era o momento de fazer isso, mas o ambiente proporcionava isso... Agora não, eles vão ter um ambiente só pra contação de história, então não vai ter acervo pra mexer na hora da contação. E, com os expositores, uma variedade maior de livros pra escolher."

Fica exposta, a partir destes depoimentos, a compreensão por parte da profissional acerca das várias formas que o ambiente e seus componentes (neste caso, o acervo e as estantes) podem colaborar ou não para a realização das atividades por parte do usuário.

A bibliotecária destaca também as mudanças positivas com a troca das estantes que, na época da entrevista, acolhiam o acervo enfileirado, o que dificultava a decodificação do título do livro pela criança, considerando que aos seis anos elas ainda estavam em fase de letramento, além de que o livro infantil costuma ter poucas páginas, o que torna a lombada fina, dificultando a leitura do título. Ela acreditava que as estantes em formato de expositor facilitariam demasiadamente a seleção dos livros pelas crianças, diminuindo o tempo gasto com esta escolha e dinamizando a aula, situação que, de fato, se concretizou.

\subsection{2 - Protagonismo Infantil e Autonomia na Biblioteca}

No que diz respeito à rotina da criança na biblioteca, em termos de atuar no ambiente de forma autônoma aproveitando-se dos recursos que ele tem a oferecer, a bibliotecária explicou que o tempo oferecido para as aulas de contação de história diminuem as possibilidades da criança usufruir do ambiente livremente, 
pois estão sempre sendo direcionados para alguma atividade.

Acerca da questão do protagonismo para explorar o acervo independentemente de adultos, o atual formato de pesquisa de acervo em computadores não é o ideal para crianças de seis anos, que são os usuários desta biblioteca, pois eles ainda estão em processo de alfabetização, tornando inviável pesquisar em computador, não só pela complexidade da atividade, como também pelo fator "tempo versus quantidade de alunos a serem atendidos". Quando querem algum livro em especial, pedem ajuda à contadora de histórias para localizá-lo ficando, desta forma, a mercê do acervo exposto para leitura.

"Na biblioteca infantil, isso seria difícil, porque eles ainda estão em processo de alfabetização... isso seria complicado." (bibliotecária quando perguntada sobre pesquisa do acervo no computador pelas crianças)

\subsection{Apropriação do espaço pelas crianças}

Quando questionada sobre a função das aulas de biblioteca e se elas colaboram para que os alunos passem a frequentar mais este espaço da escola, a bibliotecária afirma que as aulas de biblioteca motivam os alunos a frequentar o espaço, no sentido que, ao menos nesta aula, eles vão estar na biblioteca. Para muitas crianças, esta visita quinzenal à biblioteca é seu único contato com o espaço pois, nesta idade, eles não têm autorização para frequentar os outros espaços da escola sem acompanhamento de um supervisor. Como as aulas de biblioteca possuem caráter de atividade dirigida, dando ao aluno pouca ou nenhuma liberdade para escolher como gostaria de atuar neste espaço, conclui-se que a apropriação dos potenciais da biblioteca ficam diminuídos, neste caso, pois acaba por se tornar um espaço onde a criança tem hora marcada e instruções de como e quando utilizá-lo.

\subsection{Entrevista com a contadora de histórias}

Após transcrever na íntegra o áudio desta entrevista, foi possível analisar as respostas dadas às perguntas feitas à esta profissional, agrupando respostas semeIhantes nas seguintes categorias:

\subsection{0 ambiente, seus equipamentos e as atividades:}


Por se tratar de uma profissional que atua nesta escola há mais de catorze anos, Beth pôde relatar como era a biblioteca no início de sua carreira na escola. Ela afirma que, no início, era um espaço com apenas mesas, cadeiras e uma estante. Por não achar apropriado para um ambiente infantil, ela afirma que houve mudanças para tornar a biblioteca um local mais "gostoso", "um ambiente diferente".

"Vamos tirar as mesas e as cadeiras. Vamos colocar tapete, vamos colocar almofada, pro aluno se sentir mais a vontade. Então, ao longo desses anos, nós fomos mudando o mobiliário da biblioteca. Tanto que agora nós temos duas salas: uma para escolha de livros e uma sala para contação de histórias e realização de atividades. Sempre que possível, a gente muda o mobiliário, a gente muda a textura da tinta, a luminosidade, sempre melhorar cada vez mais esse contato do aluno com a biblioteca e fazer de um jeito que ele se sinta num ambiente diferente, gostoso, onde ele queira voltar mais vezes e onde ele se sinta a vontade pra aprender, pra ficar, né?"

Além disso, a profissional mencionou que o tatame de emborrachado onde as crianças sentam ou deitam durante as aulas e atividades foi escolhido para tentar diminuir alergias que algumas crianças apresentaram quando, ao invés do tatame, a sala dispunha de um tapete. Ela explica também que outras atitudes para melhorar a rotina das crianças na biblioteca foram tomadas. Dentre elas, acrescentar um expositor na biblioteca, para que os alunos conseguissem selecionar meIhor os livros (como a bibliotecária da escola já havia mencionado).

"mudamos a disposição das estantes, mudamos a estante mais pra expositor, até pra criança ter um contato maior com o acervo, coisa que antes não era disponibilizado, até pelo layout da sala ne? A criança não podia muito manusear o acervo."

Outros aspectos que devem ser levados em consideração aqui sobre a forma como o ambiente limita as possibilidades das atividades nele exercidas estão presentes na fala de Beth quando afirma que as crianças eram instruídas a sentar em lugares pré-determinados pela posição das almofadas, devido ao pouco espaço na área reservada para contação de histórias. 
"Eles não podiam escolher o lugar onde queriam sentar. As almofadas já estavam organizadas e eles tinham que sentar ali."

Ao ser questionada acerca de reclamações ou incômodos verbalizados pelas crianças sobre o ambiente em seus diversos aspectos (mobiliário, iluminação, climatização, etc), a profissional relata que era comum as crianças apresentarem queixas por não se sentirem confortáveis fisicamente no espaço, por não poderem, por exemplo, se deitar para ouvir as histórias.

"Era muito apertado e eles não tinham mobilidade. Então, às vezes, tinha uma atividade pra fazer, eles ficavam muito apertadinhos pra fazer a atividade. Ou, às vezes queriam deitar pra ouvir a história, então tinha que ser tudo milimetricamente...'oh, você vai ficar sentadinho aqui, seu amiguinho vai ficar ali' não podia se mexer muito, se não, não caberia."

É válido apontar que a contadora de histórias ressaltou que todas as modificações pertinentes ao ambiente para melhorar a rotina dos alunos foram acatadas pela diretoria da escola como, por exemplo, a instalação de cortinas para bloquear a iluminação natural quando necessária e a instalação de ventiladores nas paredes, o que demonstra a preocupação por parte da direção da escola em providenciar um ambiente o mais confortável possível para os alunos.

\subsection{2 $\mathrm{O}$ aluno enquanto protagonista na biblioteca: autonomia e apropria-} ção

Quando indagada sobre como as aulas de biblioteca colaboravam para que as crianças adquirissem autonomia e se apropriassem do ambiente da biblioteca, a profissional defende que as aulas de biblioteca existem para que os alunos conheçam as possibilidades da biblioteca, e que este tipo de atividade estimula que as crianças, em seu pouco tempo livre, passem a frequentar o espaço para ler se assim desejarem.

Pode-se concluir aqui que a entrevistada não compreendeu a essência da pergunta, pois sua resposta ressalta aspectos positivos acerca das aulas de biblio- 
teca que não necessariamente se relacionam com a apropriação do aluno em relação ao local durante as atividades exercidas na biblioteca, sejam elas em período livre ou não.

\subsection{Biblioteca: dispositivo cultural}

Para esta pesquisa, é necessário compreender como se dá o entendimento do profissional acerca do papel da biblioteca escolar. Portanto, ao analisar as respostas das questões referentes a este tema, chegou-se à conclusão que a profissional enxerga a aula de biblioteca para além do suporte e da colaboração que esta atividade dá à sala de aula tradicional.

Quando prepara as atividades da aula de biblioteca, ela cerca o momento de ludicidade, atraindo a atenção das crianças, que querem participar de todos os momentos da aulas.

"E eles ficam super ansiosos, né, porque tem uma caixa organizadora, que eu enfeito ela, dei o nome de caixa mágica, porque é dali que saem as histórias. Geralmente, eu coloco um bichinho de pelúcia da história dentro da caixa e objetos que me ajudam a compor essa história. Aí eles pegam a almofadinha pra sentar no tatame e sentam pra ouvir a história. Às vezes as crianças participam, fazendo onomatopeias dos animais, da natureza. Cada aula de biblioteca acontece de uma forma diferente. As vezes eu deixo uma dica do que vai ser a próxima aula. 'olha, eu acho que nós vamos para o polo norte' então eles ficam ansiosos, pedem uma dica da história. "

Acredita-se que este tipo de atenção para com as atividades aprofundem a experiência da criança com a aula, fazendo com que desejem passar mais tempo neste lugar e, consequentemente, colaborando para torná-lo um frequentador da biblioteca.

\subsection{Mídias eletrônicas e dispositivos de leitura digital}

A profissional acredita que é positiva a inserção de mídias eletrônicas, como o uso do computador e de projetores enquanto suporte para a realização da contação de histórias e até mesmo para realizar pesquisas escolares. 
"Às vezes eu tenho o som de uma onça, então você coloca a sonoridade do barulho da onça...a história cria vida.”

"O uso do computador nos ajuda na área da pesquisa. Eles procuram no livro, mas completam com o que acham na internet, então eles têm vários recursos para realizar a pesquisa, não apenas um."

Considera-se positivo que a profissional enxergue o uso de mídias como um suporte na realização das atividades exercidas na biblioteca, pois indica abertura para o diálogo com a inserção das mídias nos ambientes escolares e educativos em geral.

Acerca do uso de suportes de leitura digital pelas crianças, a profissional considerou positiva a experiência que teve com os alunos dos primeiros anos do Ensino Fundamental em 2015, relatando que compreende o desinteresse inicial das crianças em relação ao aparelho, mas que acredita que com novas atividades mais constantes, os alunos passem a se acostumar com o tablet enquanto uma alternativa ao livro impresso, não apenas como um aparelho para jogos eletrônicos.

É importante ressaltar que a percepção da profissional acerca dos suportes de leitura digital é importante para motivar um futuro no qual o acervo eletrônico faça parte das bibliotecas infantis e escolares, onde não haverá uma competição entre estes tipos de suporte, mas uma soma de possibilidades. A visão que a criança tem do tablet enquanto objeto voltado para jogos também é um fator que dificulta tornar rotineiro o uso deste aparelho para a realização de leitura de livros por parte das crianças. Desta forma, pode-se concluir que os passos iniciais para trazer os suportes de leitura digital para a biblioteca escolar já foram dados, mas mostrase que para concretizar enquanto rotina, ainda levará tempo.

\subsection{Observação das aulas}

Foram observadas aulas com três planejamentos diferentes, que serão apresentados a seguir:

Contextualização das aulas:

- Grupos A e B - O objetivo desta aula era transmitir aos alunos conhecimentos 
referentes às etapas de criação de um livro. As atividades desta aula foram a devolução dos livros emprestados, aula expositiva e mostra de vídeo. Durante toda a aula, os alunos permaneceram no tatame.

- Grupos C e D - O objetivo desta aula era apresentar o tablet enquanto possibilidade de dispositivo de leitura. As atividades desta aula foram mostra de vídeo, aula expositiva, uso do tablet, leitura de livro impresso.

- Grupos E, F, G - O objetivo desta aula era apresentar aos alunos um conto de fadas adaptado. As atividades desta aula foram a devolução dos livros emprestados, empréstimo de livros, contação de histórias, jogo de mímica.

-> Acesso do aluno ao acervo disponível na sala:

Grupos A, B, C, D:

A maior parte do acervo desta biblioteca, voltado para os grupos que interessam a esta pesquisa, encontrava-se organizada em estantes separado por série e por assunto. As observações dos grupos A, B, C e D apontam que os alunos não conseguiam encontrar sozinhos os livros que queriam, necessitando de instruções das profissionais presentes na biblioteca, tanto no caso de títulos específicos quanto na busca por tema.

Apesar de não conseguirem localizar os livros nas estantes sem a ajuda das contadoras, os alunos apresentaram plena facilidade em alcançar e retirar sozinhos os livros escolhidos das estantes.

Quanto ao mini-expositor da sala, foram observados momentos em que alguns alunos de menor estatura apresentaram dificuldade para alcançar os livros, alguns alunos ficaram suspensos nas pontas dos pés buscando alcançar o acervo do expositor. Além disso, algumas crianças que não conseguiam alcançar os livros e não conseguiam os que queriam, demonstraram frustração e irritação.

GRUPOS E, Fe G

Durante as aulas observadas, notou-se que os alunos não apresentaram dificuldade em devolver os livros que haviam pego emprestados anteriormente, pois 
foram devolvidos em uma caixa situada na entrada da sala do acervo. Todos os alunos observados aparentaram intimidade com as estantes e expositores. Estava permitido que escolhessem qualquer livro dos expositores para levar emprestado, o que se considera uma vantagem em relação ao mobiliário do ano passado, pois como só havia um pequeno expositor que não comportava livros suficiente para todos, eles se amontoavam na frente desse pequeno móvel. Além disso, precisavam pedir ajuda constantemente às contadoras de histórias para poder encontrar nas estantes os livros que gostariam de ler. Nota-se grande independência dos alunos com os novos expositores disponíveis na sala.

-> Apropriação do espaço pelo aluno:

Grupos A, B, C, D:

No que diz respeito à apropriação do espaço pelo aluno, notou-se que os alunos se sentem à vontade para utilizar o espaço nos horários de aula. Não se pode, porém, inferir sobre a apropriação deste local em períodos livres.

Os alunos passaram grande partes das aulas sentados ou deitados no tatame de borracha e.v.a. disponível em ambas as salas de contação de história. Por se tratarem de aulas quinzenais que acontecem durante todo o ano letivo, os alunos já haviam criado a rotina de se encaminhar diretamente para o tatame, ao entrar na sala nos dias em que as observações foram feitas.

Sobre o acervo e outros objetos presentes na sala, tais como almofadas e bichos de pelúcia, os alunos demonstraram plena capacidade de interagir com os mesmos, sem demonstrar receio em retirar livros das estantes ou dos expositores.

Desta forma, pode-se falar da existência de intimidade do usuário com o ambiente, no sentido que se sentem a vontade para fazer uso da sala e manusear os objetos ali presente, pois já frequentam este espaço há, no mínimo, um ano letivo.

Grupos E, F, G:

Em ambas as salas (do acervo e de contação de histórias), os alunos se mostraram a vontade para utilizar o espaço oferecido e para interagir com os componentes destes ambientes, principalmente na sala do acervo, onde a atividade 
dependia apenas da livre escolha dos livros.

Na sala de contação de histórias, os lugares para que eles se sentassem inicialmente já estavam pré-determinados com as almofadas, mas com o decorrer da aula, eles deitaram no tatame e reconfiguraram a organização do espaço, devido às atividades subsequentes.

Faz-se necessário afirmar que o caráter da atividade, que é o momento da contação de história, deixa o aluno livre para que deite no tatame para ouvir a história, mas também pede controle para que eles não mexam com bonecos de pelúcia em horários indevidos ou com instrumentos musicais, por exemplo. Sabe-se que, por ser uma aula, apesar de descontraída, isto influencia na autonomia da criança no espaço, pois limita suas possibilidades de atuação no ambiente. Assim, de forma similar aos grupos previamente observados, pode-se falar de intimidade com o ambiente e seus componentes, no sentido de rotina, porém não se pode tecer conclusões acerca da apropriação do espaço num sentido mais amplo.

-> Conforto durante as aulas assistidas

As posições a seguir foram as mais observadas entre os alunos, no geral, durante as aulas:

Alguns alunos deitaram nesta posição mas não se demoraram. acredita-se que a distância dos olhos à tela pequena do computador que estava a uma altura elevada em relação aos olhos das crianças não permitia que eles visualizassem bem a tela.

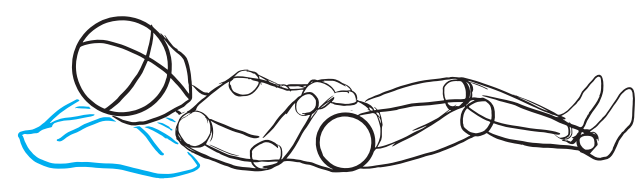

Figura 55 - Principais posições realizadas pelas crianças observadas. Fonte:Autora

Muitos alunos deitaram nesta posição abraçados a um bicho de pelúcia. desta forma, ficaram em silêncio, atentos ao vídeo e não demonstraram desconforto físico.

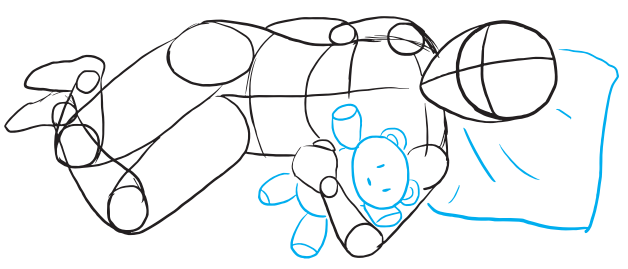

Figura 56 - Principais posições realizadas pelas crianças observadas.

Fonte:Autora 


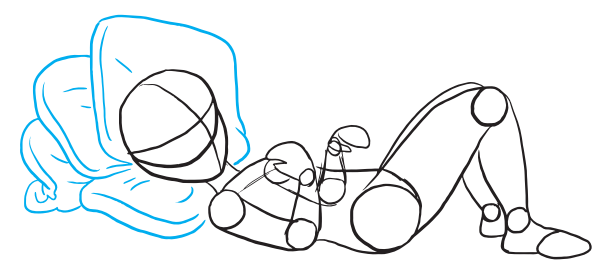

Figura 57 - Principais posições realizadas pelas crianças observadas.

Fonte:Autora

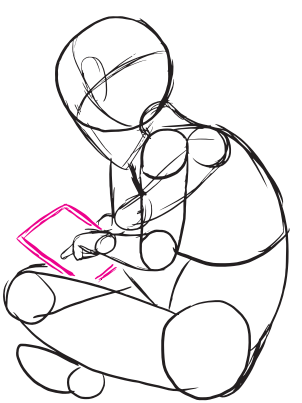

Figura 58 - Principais posições realizadas pelas crianças observadas.

Fonte:Autora

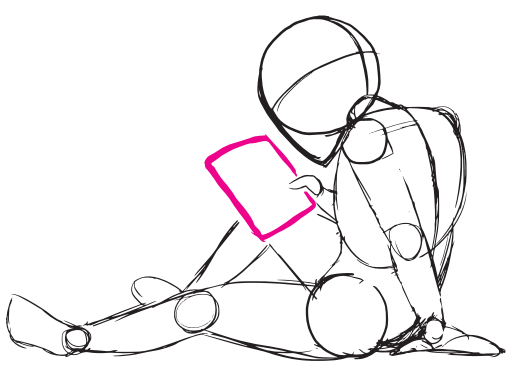

Figura 59 - Principais posições realizadas pelas crianças observadas.

Fonte:Autora

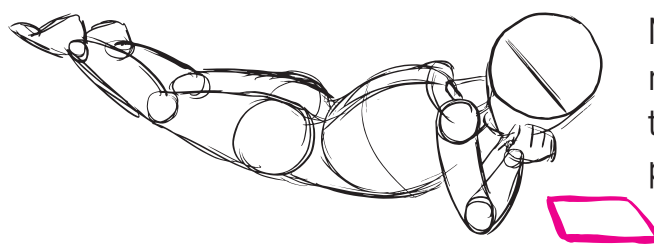

Muitos alunos passaram por esta posição durante a leitura com tablet. a mão apoiada no tatame serviu para descansar o peso do corpo enquanto liam.

Figura 60 - Principais posições realizadas pelas crianças observadas.

Fonte:Autora 
Os alunos que tentaram usar o tablet nesta posição não permaneceram por mais de 2 minutos, devido ao peso do aparelho nas pernas, à falta de suporte para a coluna e à dificuldade para manusear e segurar 0 aparelho ao mesmo tempo.
Alguns alunos chegaram a passar mais de 3 minutos lendo nesta posição, o que leva a acreditar esta seja uma das posições mais confortáveis para eles.
Os poucos alunos que escolheram esta posição, permaneceram assim até o final da leitura do livro.

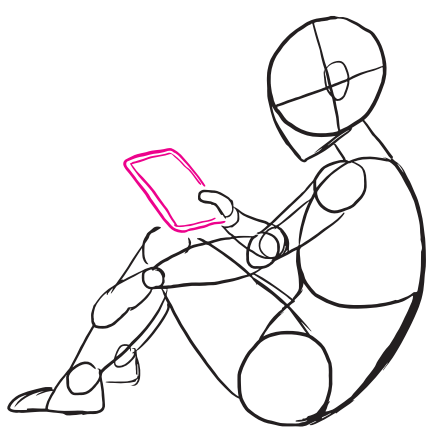

Figura 61 - Principais posições realizadas pelas crianças observadas.

Fonte:Autora

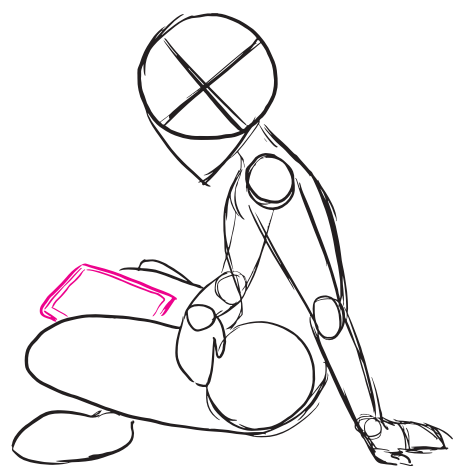

Figura 62 - Principais posições realizadas pelas crianças observadas.

Fonte:Autora

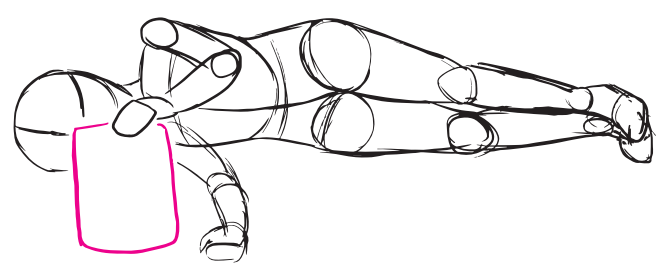

Figura 63 - Principais posições realizadas pelas crianças observadas.

Fonte:Autora

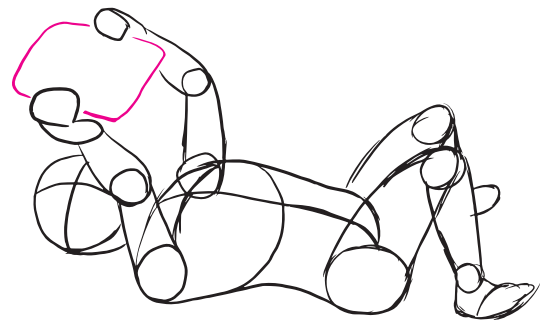

Figura 64 - Principais posições realizadas pelas crianças observadas.

Fonte:Autora 


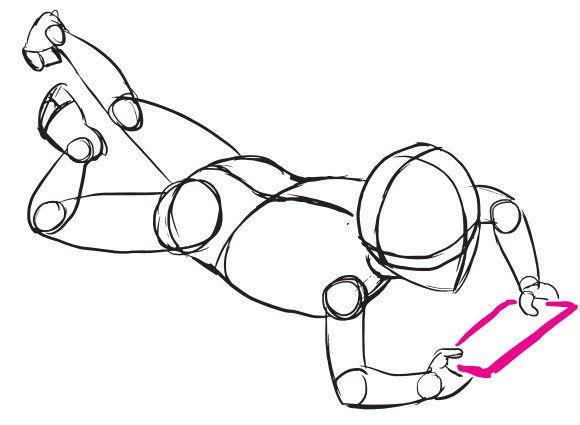

Figura 65 - Principais posições realizadas pelas crianças observadas.

Fonte:Autora

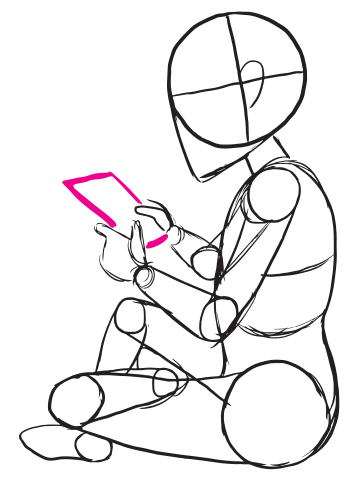

Figura 66 - Principais posições realizadas pelas crianças observadas.

Fonte:Autora
Os alunos não se demoraram assim devido ao peso que o tablet implica aos punhos, dificultando também a mudança de páginas durante a leitura.
Todos os alunos observados passaram por esta posição enquanto liam, apesar de não demorarem muito. acredita-se que o peso do aparelho influenciou na mudança para outras posições. trazer a tela próxima aos olhos ocorreu diversas vezes.

Grupos A, B, C, D:

Os alunos que atuaram nesta biblioteca tiveram a possibilidade de interagir com animais de pelúcia e com almofadas durante as aulas, além da possibilidade de leitura de livros em tablets. Pode-se observar que todos os alunos mudavam de posição constantemente. A falta de apoio para a coluna parecia ser a principal razão, além do fato de, diversas vezes, os alunos quererem interagir e trocar opiniões, fazendo com que mudassem de posição. Os croquis nas figuras abaixo mostram as principais formas de sentar e de deitar no tablado das crianças na biblioteca

Grupos E, F, G:

Percebeu-se, a partir das observações, que os alunos não demonstravam desconforto físico durante as aulas. Além de conseguirem deitar no tatame para ouvir a história, fator impossibilitado pela falta de espaço quando a biblioteca con- 
tava apenas com uma sala, os alunos agora podem realizar atividades e jogos que antes a falta de espaço não permitia, como a piscina de almofadas que ocorreu nas aulas observadas. Os alunos puderam correr, brincar e se movimentar com mais liberdade. Além disso, a contadora de histórias se posicionou a uma distância meIhor dos alunos para que eles pudessem observar as gravuras do livro enquanto ela lia para eles. Na sala anterior, os alunos reclamavam de não conseguirem enxergar as imagens do livro enquanto era narrado.

Depreendeu-se que a falta de espaço físico para comportar o número de alunos nos grupos A, B, C e D com conforto e a falta de assento ou de um apoio para as costas das crianças foram os fatores que mais atrapalharam a execução das atividades.

Outro aspecto observado foi que o uso do computador de mesa, além de não estar bem posicionado em relação à altura dos olhos das crianças, não era o ideal para a quantidade de crianças na sala assistir aos vídeos. Com a criação de uma Sala de Contação de Histórias, em 2016, este problema foi eliminado, com a instalação de um projetor para este tipo de atividade.

-> Relação com o mobiliário durante as aulas

Grupos A, B, C, D:

No que diz respeito a um uso efetivo do mobiliário (considerando-se, neste caso, ações realizadas com o intuito de promover o uso para o qual o mobiliário foi designado), pode-se constatar com as observações que a altura das estantes estava adequada a seu usuário, em ambas as bibliotecas, bem como não aparentaram oferecer riscos de acidente.

Como quase todos os alunos pisavam no tatame de e.va de tênis, ambos os tatames apresentavam marcas das solas dos sapatos, indicando que estes não estão adequados para o uso feito pelas crianças, pois muitas destas se deitam com os rostos nestes tatames, podendo respirar a poeira trazida pelos tênis e desenvolver alergias.

Outro fator observado sobre os tatames é que são formados a partir do encaixe de módulos quadrados, em formato de peças de quebra-cabeça. Portanto, era comum durante as observações, presenciar alunos puxando para cima as bordas das peças com o intuito de desencaixá-las, o que não só distraia outros alunos, como também pode vir a danificar o tatame a longo prazo. 
Grupos E, F, G:

$\mathrm{Na}$ Sala do Acervo, os alunos se relacionaram de maneira íntima com as estantes de livros. Todos foram capazes de alcançar as estantes e os expositores desejados. Quanto ao uso do tatame (único local disponível como assento para os alunos nesta sala), verificasse que este arranjo permite que os alunos se sentem de diversas maneiras, sozinhos ou em grupo. Tanto para esta sala quanto para a Sala de Contação, o tatame é utilizado como espaço para reunião dos alunos, onde estes desenvolvem também as atividades propostas (sejam elas brincadeiras ou exercícios de escrita). Foi observado que as crianças pisam de tênis em ambos os tatames e que se deitam nestes mesmos objetos. Além disso, observou-se também que as crianças encostavam os rostos com frequência no tatame, além de passar as mãos no rosto e na boca após manusear o tatame, ação que pode contribuir para a proliferação de doenças e alergias.

A Sala de Contação também conta com almofadas, que os alunos utilizam para encostar a coluna contra a parede, para deitar a cabeça no tatame ou até mesmo para outras funções em brincadeiras. Constatou-se que a manipulação deste objeto deve ser repensada por questões de higiene relacionadas com o fato de as crianças encostarem as almofadas no chão, no qual pisam de tênis. Os alunos não demonstraram dificuldades em acessar as caixas de brinquedos e acessórios utilizados durante as aulas, que se encontravam no fundo da sala, ao alcance das crianças.

-> Experimentação com tablets

Grupos C e D:

Os alunos puderam experimentar a leitura de histórias em tablets emprestados do departamento de informática da escola. Cada aluno teve direito a um aparelho. Notou-se que a grande maioria dos alunos estava muito ansiosa para realizar a atividade, porém parte deles se desinteressou quando compreendeu que o aparelho seria utilizado apenas para leitura e não para jogos.

Quanto ao manuseio do aparelho pelas crianças, era a primeira vez que todos eles estavam manuseando um tablet com o objetivo de realizar a leitura de um livro. Desta forma, todos precisaram de constante ajuda da profissional para se 
manter na história, para passar as páginas dos livros ou até mesmo para ampliar ou reduzir as ilustrações dos mesmos. Desta forma, a maior parte dos alunos se mostrou angustiada ou frustrada em alguns momentos da realização da atividade, por precisarem constantemente da ajuda da adulta.

Com o passar do tempo, as crianças se mostraram mais à vontade com o aparelho e mais interessadas em fazer uso deles para leitura, apesar de ainda ter havido alguns pedidos para utilizar o tablet para jogos. Quando a contadora anunciou que quem quisesse poderia devolver os tablets e ler o acervo impresso, a maior parte dos alunos devolveu os aparelhos e buscou fazer a leitura dos impressos, individual ou em grupos.

Por se tratarem de crianças pequenas, notou-se também dificuldades físicas para manusear o aparelho, pois era muito pesado e grande para as crianças. Além disso, algumas crianças tentaram manuseá-lo como se faz com o acervo impresso, em posições que não favoreciam a leitura com tablet (assunto discorrido no tópico sobre conforto físico neste capítulo).

Acredita-se que esta rejeição inicial seja compreensível e esperada, pois as crianças estavam lidando com um aparelho que, apesar de conhecerem, não sabiam como utilizar para leitura de livros. Além disso, considera-se a experiência positiva, pois apresentou uma forma alternativa de leitura, juntamente com seus pontos positivos pela profissional no início da atividade. É importante ressaltar também que apesar da maioria das crianças ter realizado a leitura nos tablets de forma individual, algumas se ajudaram a manipular o aparelho e leram algumas histórias juntas, o que desmistifica uma possível introspecção que este tipo de aparelho poderia trazer para a socialização das crianças.

\subsection{Storytellings}

Os storytellings foram aplicados com alunos que frequentaram a Biblioteca Alfa e que se encontravam na primeira série do Ensino Fundamental, pois é série na qual a grande maioria das crianças está na média dos seis anos de idade.

Considerando-se a impossibilidade de aplicar a atividade na biblioteca por que o cronograma das aulas de biblioteca não permitiam, foi pedido aos pais ou responsáveis que direcionassem a atividade às crianças em casa no tempo livre dos 
alunos. O documento enviado instruindo adultos sobre o processo do storytelling encontra-se no Apêndice desta pesquisa.

Os resultados da aplicação dos storytellings com os alunos foram obtidos a partir das análises das representações gráficas produzidas pelas crianças. Buscou-se agrupar em categorias de interesse para a pesquisa os aspectos que mais incidiram nos desenhos. No total, foram analisados 14 desenhos.

A seguir, os aspectos analisados:

\section{Ludicidade:}

Buscou-se aqui analisar se as crianças expressaram em seus desenhos aspectos lúdicos, tanto representando objetos que remetessem ao brincar quanto que ilustrassem objetos ou atividades lúdicas.

Observou-se, em 6 dos 14 desenhos, ilustrações representantes da ludicidade, sendo que, em 4 destes, os bichos de pelúcia apareceram como objeto da biblioteca. A Biblioteca Alfa possui caixas com bichos de pelúcia, que os alunos podem usar para acompanhá-los enquanto escutam a contação da história na aula de biblioteca. Além disso, foram desenhados um baú com fantasias, um navio, jogos de tabuleiro, uma mesa para desenhar e adesivos decorativos na parede.

A presença de elementos como a mesa de desenhar e o baú com fantasias apontam que as crianças veem o ambiente da biblioteca não apenas como local para leitura ou aula, mas como espaço de múltiplas possibilidades e atividades lúdicas.

\section{Conforto corporal:}

Notou-se que muitos dos desenhos traziam diferentes formas de assento para a biblioteca (cadeira, puff, bancos, almofadas, tapetes, sofá), cuja única alternativa real de assento para as crianças é o tatame onde realizam todas as atividades na biblioteca.

Acredita-se que a manifestação do desejo de diferentes formas de assento para a biblioteca seja uma maneira de explicitar a necessidade de mais conforto que é gerada pela ausência destes elementos na biblioteca.

\section{Organização espacial:}


Considerando-se a idade destas crianças, os desenhos desenvolvidos por elas trazem cenas num formato de fachada, onde agrupam todos os elementos que desejam no desenho. Algumas das crianças expressaram no desenho um desejo de organização espacial detalhado, posicionando os elementos e mobiliários no formato que gostariam que fosse na biblioteca.

"Gostaria que a biblioteca fosse maior com 1 sala só." (citação de dois alunos)

"Estantes suspensas do jeito que está." (citação de dois alunos)

"Gostaria que biblioteca fosse maior, com livros na mesma sala da história."

\section{Atividades:}

Percebeu-se que os desenhos traziam múltiplas atividades a serem realizadas na biblioteca: Desenhar, teatrinho, assistir filmes ou vídeos, leitura, interação e diálogo com amigos e com professoras, contação de histórias, observação de quadros.

Uma das crianças apontou em seu desenho um passo-a-passo de como a biblioteca deveria funcionar. Nesta indicação, a criança descreve uma situação em que é possível realizar a leitura individual na biblioteca, tendo como alternativa explorar o acervo, fazer o empréstimo do livro e, caso termine de ler os livros em tempo hábil, existe ainda a possibilidade de a pessoa olhar os quadros pendurados na parede da biblioteca.

\section{Mobiliário e equipamentos}

Dos 14 desenhos, 11 traziam uma leitura da biblioteca com características em sua maioria de caráter tradicional do que se espera de um ambiente deste tipo. Todos os 11 desenhos trouxeram a estante com prateleiras como a maneira de se guardar o acervo.Na maior parte dos casos, estas estantes estão representadas como mobiliário comprido e alto, repleto de livros coloridos. Em dois desenhos, as estantes com livros são os únicos elementos que retratam a biblioteca para a criança.

Também apareceram espaços na biblioteca que seriam voltados para a professora ou contadora de histórias, como escrivaninha com cadeira para a pro- 
fessora de biblioteca e outro caso onde uma mesa e uma cadeira representavam o espaço voltado para empréstimo dos livros.

Os desenhos, em sua maioria, trouxeram diferentes formas de assento e almofadas. Os recursos eletrônicos que apareceram nos desenhos foram o retroprojetor e o computador.

6. Outros:

A iluminação do ambiente apareceu em um dos desenhos apenas, onde a criança desenha dois lustres iluminando a área de leitura e do computador na sala.

Uma das crianças apontou no desenho que "gostaria que a biblioteca fosse um prédio com muitos andares com livros. E que pudesse visitar todos os dias".

Uma das crianças mencionou que gosta da biblioteca como ela está.

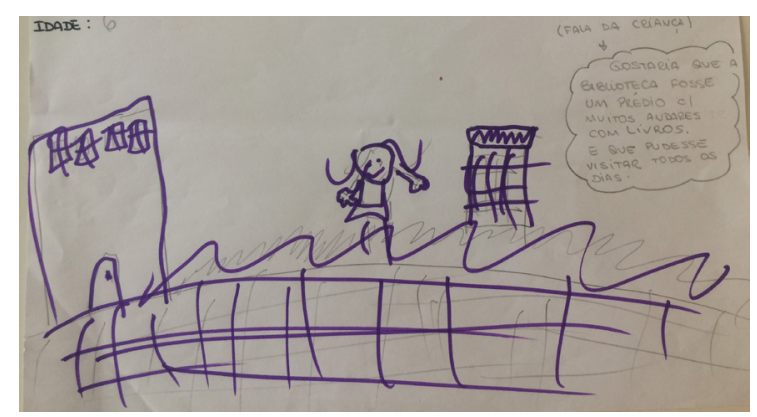

Figura 66 - Um dos storytellings desenvolvido por uma aluna do Colégio X. (2016)

Fonte:Autora

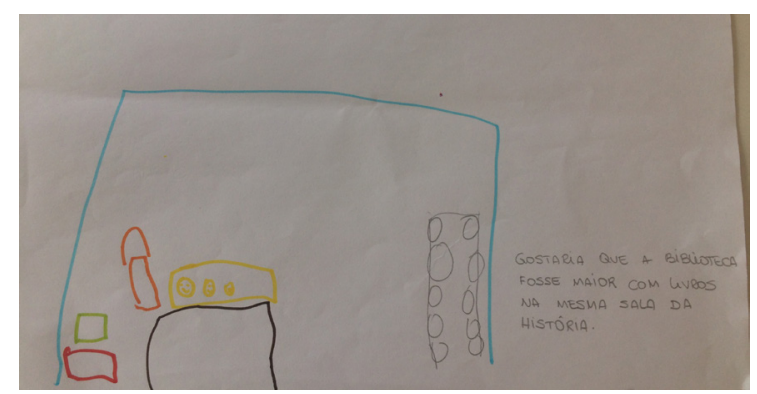

Figura 67 - Um dos storytellings desenvolvido por um aluno do Colégio X. (2016)

Fonte:Autora 


\subsubsection{Biblioteca Beta}

Esta biblioteca atende aos alunos do segundo ano do Ensino Fundamental ao terceiro ano do Ensino Médio. Além disso, o espaço e o acervo estão abertos e disponíveis também para os pais dos alunos, para os funcionários da escola, e para os alunos do curso de supletivo oferecido para moradores da região onde a escola se encontra.

O espaço físico desta biblioteca conta com:

•Balcão na entrada principal (para recepção, empréstimo e devolução do acervo)

- Sala de estudos (para uso individual ou em grupo)

- Estantes no corredor com acervo para alunos a partir do sexto ano do Ensino Fundamental

-Sala de projeção

-Sala de Contação de Histórias (para alunos do segundo ao quinto ano do Ensino Fundamental)

-Banheiros (1 masculino e 1 feminino)

- Hall para exposição temática ou dos trabalhos dos alunos

Para esta pesquisa, foi considerada apenas a Sala de Contação de Histórias pois, além de ser o espaço destinado às atividade de Aulas de Biblioteca, é ali que se encontra também todo o acervo voltado para o grupo de crianças na faixa etária que interessa ao estudo em questão. 


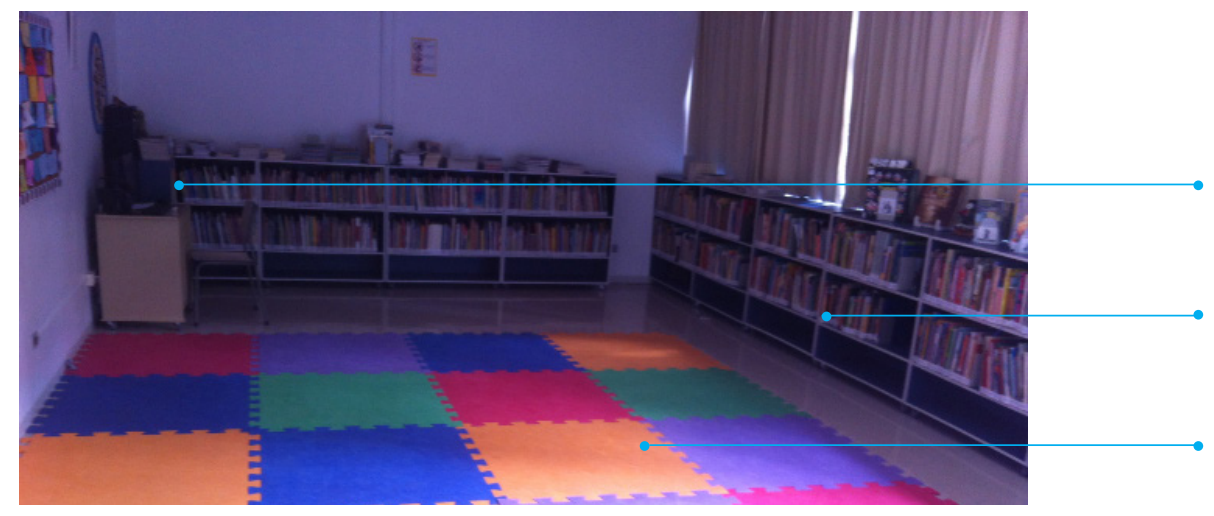

Figura 68 - Biblioteca Beta (2015)

Fonte: Autora computador para pesquisa

estantes com o todo o acervo dos $2^{\circ}$ ao $5^{\circ}$ ano

tatame onde os alunos realizam todas as atividades na sala

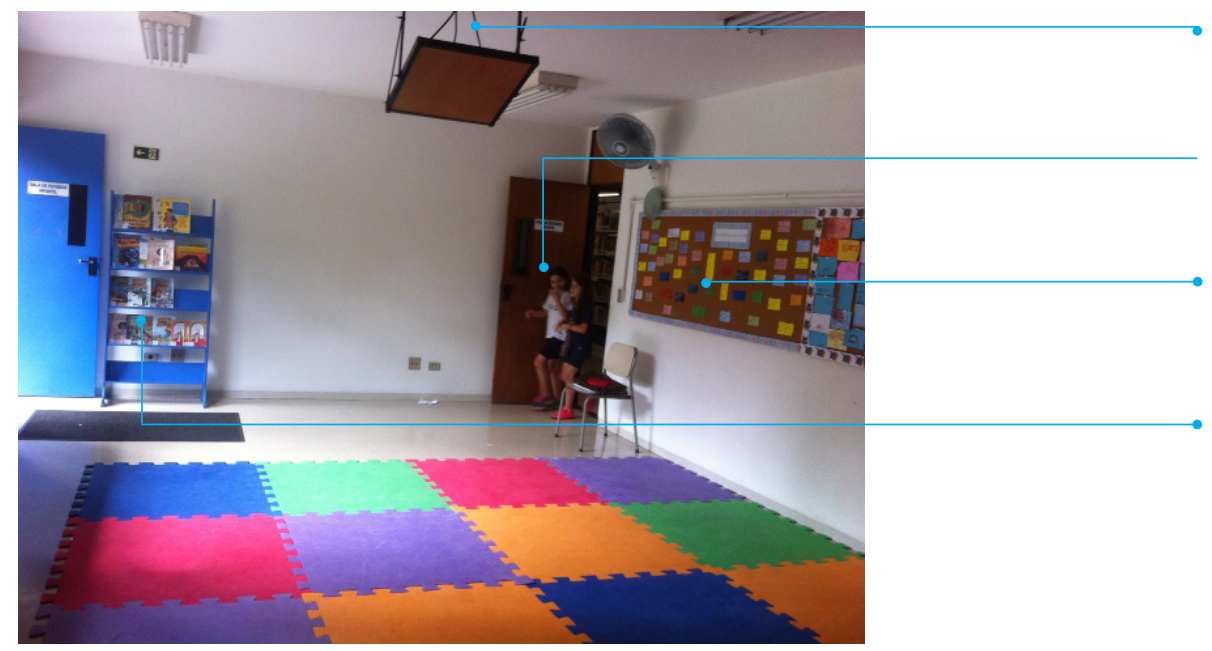

projetor de imagens e vídeos

porta de entrada via interior da biblioteca

mural com avisos e informações

um dos expositores com indicações para empréstimo

Figura 69 - Biblioteca Beta (2015)

Fonte: Autora

\section{QUADRO 24 - RELAÇÃO DE MOBILIÁRIOS E EQUIPAMENTOS DA BIBLIOTECA BETA}

\section{PARA USO INFANTIL}

- estantes de madeira que circundam 3 paredes da sala, dividindo o acervo de acordo com a série

- três expositores com indicações para empréstimo

- computador para pesquisa

- tatame de e.v.a. constituído por módulos de $1 \mathrm{~m}$ x $1 \mathrm{~m}$

\section{PARA USO DE ADULTOS}

- um computador para pesquisa e outras atividades

\section{OUTROS EQUIPAMENTOS}

-2 ventiladores acoplados na parede

-1 mural informativo

- 1 projetor de imagens e vídeos

Fonte: Autora 


\subsubsection{Resultados obtidos}

\subsection{Entrevista com a bibliotecária}

A bibliotecária do Colégio X atua em ambas as bibliotecas analisadas nesta pesquisa. Desta forma, foi realizada apenas uma entrevista com a profissional e parte das respostas adquiridas no processo é pertinente a ambas as bibliotecas. Para a Biblioteca Beta, couberam as seguintes categorias após a transcrição na íntegra dos áudios da entrevista:

\subsection{Relação bibliotecária e ambiente}

A bibliotecária afirma que o espaço físico destinado para a Sala de Contação de Histórias, onde se localiza também o acervo voltado para os alunos entre sete e nove anos, é grande o suficiente para acomodar todas as crianças do mesmo grupo para assistir às aulas de biblioteca.

Além disso, a profissional está satisfeita com os equipamentos e mobiliários que compõem este ambiente, além dos aspectos lúdicos e decorativos envolvidos. A única ressalva levantada pela profissional acerca do ambiente reside na necessidade de mais estantes para acomodar o acervo referente ao $2^{\circ}$ ano do Ensino Fundamental, que a partir de 2016 passou a fazer parte desta biblioteca.

"Eu sinto que o ambiente é adequado. A Sala de Contação é grande, cabe a turma toda." "E o acervo estava muito apertado, então eu senti a necessidade de comprar mais estantes e coube direitinho."

O que se pode depreender da fala da profissional é que sua visão acerca do ambiente da Sala de Contação de Histórias da Biblioteca Beta reside nos aspectos úteis e funcionais da Sala, justificado inclusive por sua função de gestora do local, cuja principal preocupação em relação ao ambiente é de que este esteja em condições para que as atividades aconteçam. Desta forma, é de se esperar que a ludicidade e o conforto físico não sejam prioridades para a profissional. 


\subsection{Autonomia na Biblioteca:}

As respostas da entrevistada às perguntas pertinentes a estes assuntos demonstram que existe uma preocupação por parte da bibliotecária em aumentar ao máximo a autonomia das crianças que frequentam a Biblioteca Beta. Esta afirmação é feita baseada na fala da profissional ao mencionar que, desde de 2016, as profissionais envolvidas com a biblioteca estão tentando aumentar a autonomia da criança em relação à pesquisa do acervo nos computadores da biblioteca. Na Sala de Contação de história há um computador que pode ser utilizado pelos alunos para pesquisa do acervo, porém não há uma tradição de autonomia para que eles realizem esta pesquisa sozinhos, situação que a bibliotecária está tentando reverter. Ela ressalta que compreende que esta é uma atividade que requer tempo e diversas tentativas, mas que eles estão tentando acostumar as crianças a fazerem esta pesquisa sozinhos.

"Vamos, aos poucos ensinando. 'Vem aqui, eu vou te ensinar a pesquisar no computador. E ensinamos. Alguns já começaram a pesquisar sozinhos."

Sabe-se que a questão da autonomia na biblioteca vai muito além da capacidade de localização de determinado livro no acervo, porém a ação da bibliotecária em tentar fazer com que os alunos se emancipem neste sentido já é uma forma de torná-los mais íntimos dos processos pertinentes ao uso da biblioteca.

\subsection{Apropriação da biblioteca pelos alunos:}

A bibliotecária afirma que crianças a partir do $6^{\circ}$ ano do Ensino Fundamental passam a frequentar a biblioteca cada vez menos e acredita que isto se dê porque as aulas de biblioteca só existem para os grupos até o $5^{\circ}$ ano. No entanto, ela relatou que a frequência em horário livre por alunos que possuem as aulas de biblioteca em sua grade curricular é consideravelmente alta. A profissional afirma que, apesar de não haver um espaço na biblioteca voltado para a leitura individual ou atividades semelhantes, a Sala de Contação de Histórias é aberta para uso dos alunos quando não está sendo utilizada para aulas. 
"Porque depois, no sexto ano, o que acontece? Eles não têm mais aula de biblioteca, eles vão lá com o professor quando precisam realizar alguma atividade, mas não têm mais essa obrigatoriedade. E a gente sente que perde os alunos, né? Ficam aqueles que realmente gostam muito de ler."

A partir da fala da bibliotecária, assume-se que a escola deveria repensar a forma como a biblioteca é apresentada aos alunos. De fato, a gestora executa diversas ações para atrair a atenção dos alunos para a biblioteca, como exposição de trabalhos, exposições temáticas, o blog da biblioteca etc. Porém estas ações somadas à obrigatoriedade das aulas de biblioteca quinzenais não são suficientes para despertar o interesse de grande parte dos alunos para se apropriar da biblioteca.

Acredita-se que os alunos desconheçam as inúmeras possibilidades referentes ao uso da biblioteca escolar, que vai muito além da pesquisa didática e da leitura dos livros impostos pela grade curricular. Além disso, é importante mencionar que a falta de espaços voltados para o lazer e para a leitura individual com mobiliários, equipamentos e um senso estético que estimule o uso deste possível ambiente, pode ser um dos fatores que diminuam o interesse das crianças em utilizar a biblioteca em seus horários livres.

\subsection{Entrevista com a Contadora de Histórias}

As perguntas que nortearam a entrevista semi-estruturada para esta profissional foram as mesmas que serviram de apoio para a profissional da Biblioteca Alfa, e tinham como objetivo captar informações acerca da forma como se conduziam as aulas de biblioteca, a relação da criança com os aparatos físicos do espaço, com o acervo e a opinião da profissional acerca do ambiente e dos artefatos que o compõem.

Ao dar sua opinião acerca de como deve ser uma sala de contação de histórias, a profissional afirma que não acredita ter conhecimento suficiente para opinar com muita profundidade sobre o tema, porém relata que, em sua opinião, o aluno deve ter acesso a um ambiente que seja diferenciado do tradicional espaço de leitura, mas que não deixe o aluno muito "solto" para dispersar da aula, dando ênfase ao quesito que, apesar de toda a ludicidade, trata-se de uma aula. 
"A aula de biblioteca tem que ser diferenciada, como eu já falei. Mas também não pode ser confundida com lazer. Tudo tem que ter uma determinada ordem, disciplina. Mas também nada que você tenha que sentar, ficar assim (interpreta com gestos de um corpo rígido) pra ouvir a contação."

A profissional afirma também que os alunos não apresentam dificuldade para alcançar os livros nas estantes, no que diz respeito à altura e posicionamento do mobiliário na sala. Relata também que a dificuldade está em localizar o acervo, por causa da organização do mesmo. Sobre este fato, ela relata que os profissionais da biblioteca estão empenhados em reverter esta realidade de dependência do profissional por parte dos alunos, aos poucos, quando surgem ocasiões que dão a oportunidade.

Sobre problemas relacionados à acústica, climatização ou iluminação, ela afirma que o ambiente atende às expectativas, tanto dela quanto das crianças, pois estas nunca se queixaram em relação a estes aspectos relativos ao ambiente.

Ao ser questionada acerca de possíveis mudanças que ela realizaria naquele ambiente se possível, a única questão levantada pela profissional foi a da ludicidade:

"...essa coisa da ornamentação com um pouquinho mais de ludicidade. Mesmo se tratando de alunos maiores que não querem mais ser crianças, mas por ser uma sala de contação de histórias é esse mundo maravilhoso, né? De encantamento, de magia, que passa por isso também. Então a única coisa que eu solicitei é que a gente faça uma decoração um pouco mais colorida, digamos assim. Eu acho o branco muito sóbrio para a sala."

A necessidade de se oferecer um ambiente lúdico aos alunos reverbera na fala da entrevistada, que nota a ausência ou a pouca presença deste fator na biblioteca em questão, sendo, portanto, um déficit encontrado neste ambiente.

Além de ter comentado durante a entrevista que esta é sua primeira experiência lecionando em uma Sala de Contação de Histórias, a profissional também aponta para sua falta de conhecimento sobre o tema da organização espacial e de mobiliários pertinentes a este tipo de ambiente. No entanto, se mostra satisfeita 
com o ambiente na forma em que se encontra. É interessante atentar para o momento em que ela afirma que as aulas de biblioteca, apesar da essência lúdica não deve ser confundida com lazer. Esta fala da entrevistada aponta para a imposição da aulas de biblioteca enquanto atividade que, com seus objetivos pedagógicos, acabam por se tornar, de fato, uma aula, por mais lúdica que seja. Desta forma, as crianças que apenas vão à biblioteca para assistir às aulas de biblioteca não estão usufruindo deste local no sentido de lazer, que deveria também ser parte da proposta da biblioteca escolar.

\subsection{Observações não- participantes}

As observações não-participantes foram realizadas pela pesquisadora no momento das aulas de biblioteca, conforme citado na sessão 4. Métodos e Ferramentas desta pesquisa, tópico onde podem ser encontradas as descrições acerca do método e informações acerca dos grupos observados.

Contextualização das aulas:

-Grupos H, le J:

Estes grupos tiveram o mesmo conteúdo de aulas de biblioteca. Houve, primeiramente, a devolução dos livros emprestados. Depois, os alunos assistiram à contação de uma história que teve a participação de alguns alunos para encenar a história. Quando a história foi finalizada, os alunos foram divididos em trios e realizaram uma breve atividade no tatame. Finalmente, os alunos puderam escolher alguns livros para levar emprestado, se dirigiram ao balcão de empréstimo e, por fim, saíram da biblioteca acompanhados da professora de sala de aula.

\section{-Grupo K:}

Os alunos entraram na sala e devolveram os livros emprestados, depois sentaramse no tatame para realizar a atividade principal da aula: um debate sobre um livro. A aula utilizou-se do recurso de retroprojeção de imagens e de vídeos para ilustrar a fala. Quando encerrou-se a atividade, os alunos puderam escolher alguns livros para levar emprestado, se dirigiram ao balcão de empréstimo e, por fim, saíram da biblioteca acompanhados da professora de sala de aula. 
- Grupos L, M e N:

Após adentrarem a Sala de Contação de Histórias, os alunos devolveram os livros que haviam levado em empréstimo e sentaram no tatame para o início da aula de biblioteca. A aula consistia na contação de uma história. Houve também um breve debate sobre a história. Por fim, a professora exibiu um vídeo projetado na parede da sala, para expor aos alunos o tema do racismo. Devido à proximidade do final do ano letivo, os alunos não puderam levar livros emprestados para casa e se dirigiram para suas salas de aula ao final da aula de biblioteca.

-Grupo O:

Nesta aula, os alunos entraram na Sala e devolveram os livros emprestados. Os alunos sentaram no tatame para a contação da história, que foi realizada por voluntários. Foi utilizado o recurso de projeção das ilustrações do livro na parede da sala, para que os alunos pudessem acompanhar enquanto a leitura da história era feita. Por fim, houve um debate sobre o tema abordado. Quando encerrouse a atividade, os alunos puderam escolher alguns livros para levar emprestado, se dirigiram ao balcão de empréstimo e saíram da biblioteca acompanhados da professora de sala de aula.

- Grupos P e Q:

Os alunos entraram na Sala e viveram um breve momento de encenação que remetia a momentos de terror, tema abordado com todos os grupos durante a Semana do Horror. Depois, as crianças sentaram no tatame para ouvir a história, que contou com o uso do computador para o recurso de sonoplastia. Ao final da história, os alunos tiveram um breve momento para selecionar nas estantes ou nos expositores livros para empréstimo, realizaram o empréstimo e se dirigiram para suas salas de aula.

Análise dos dados obtidos com as observações levaram aos seguintes resultados:

\section{Acesso do aluno ao acervo disponível na sala}

$2^{\circ}$ ANOS - Grupos H, l e J: 
O que se pôde concluir, a partir das observações dos grupos de alunos atuando no ambiente, é que os usuários não apresentaram dificuldade em alcançar os livros nas estantes da sala. Já nos expositores, os livros que se encontravam nas prateleiras mais altas eram de difícil acesso para algumas crianças de menor estatura. Foi observado que os alunos que não alcançavam as prateleiras mais altas ficavam nas pontas dos pés para tentar pegar o livro e apoiavam o peso do corpo nos expositores.

No que concerne o acesso ao acervo no sentido de localização de determinada obra, percebeu-se que os alunos escolhiam aleatoriamente dentro da gama de livros ofertadas e, caso quisessem um livro específico, perguntavam aos adultos presentes onde encontrá-lo. Além disso, ressalta-se que foi observado uma distinção entre os livros permitidos para os alunos, separados nas estantes de acordo com a série em que se encontravam. Alguns alunos foram advertidos a não mexer em livros de outras séries quando tentaram fazê-lo.

3० ANOS - Grupos K, L, M, N:

Notou-se, durante as observações, que os alunos destes grupos não demonstraram dificuldades relacionadas a aspectos físicos para alcançar os livros das estantes ou dos expositores. No entanto, foi observado também que estes alunos não possuem autonomia para localizar sozinhos os livros desejados nas estantes. Não foi possível concluir se esta falta de autonomia reside na falta de compreensão do significado da sinalização do acervo e das estantes ou por outros motivos. Foi observado também que os alunos se dirigiam com frequência aos adultos para pedir que localizassem no acervo livros específicos.

$4^{\circ}$ ANOS - Grupos O, P, Q:

No que concerne os aspectos relativos ao alcance do acervo por parte do usuário, os alunos observados não demonstraram dificuldades em alcançar os livros nas estantes ou nos expositores.

No entanto, em relação à organização do acervo e à autonomia do aluno para localizar livros de temas específicos ou por título, notou-se que muitas crianças recorriam aos adultos presentes para que estes localizassem os livros nas estantes. 
Foi observado que alguns alunos tentaram pesquisar no computador localizado neste ambiente, títulos no sistema de busca da biblioteca, porém foi observado que nenhum deles tinha autonomia para fazer a pesquisa sozinhos, necessitando sempre da ajuda de um adulto, além não demonstrarem intimidade com o computador disponível na sala para pesquisa.

Conclui-se que no que diz respeito a aspectos de funcionalidade das estantes e dos expositores, apenas foram observadas questões de alcance com algumas crianças dos $2^{\circ}$ anos. Assim sendo, para a grande maioria dos alunos, estes mobiliários cumprem seus quesitos funcionais, necessitando apenas ser repensado em relação aos alunos mais novos, que não alcançaram as prateleiras mais altas do expositor.

Em relação à autonomia dos alunos perante o acervo, conclui-se que a divisão dos livros de acordo com as séries vem a ser um problema pois nas três séries houve casos de alunos que foram instruídos a não mexer no acervo pertinente a outros grupos. Neste sentido, conclui-se que o protagonismo da criança e sua atuação autônoma é diminuído em parte por essa compartimentalização do saber, que restringe os alunos a um grupo limitado de informações. Além disso, observou-se em todas as séries a necessidade de intervenção do adulto para a localização de títulos específicos, fator que também demonstra a dependência do aluno em relação às profissionais da biblioteca, inclusive nas poucas tentativas de alunos do $4^{\circ}$ ano em localizar, via pesquisa do acervo no computador da Sala, as obras que procuravam.

Desta forma, concluiu-se que, apesar do vasto acervo e do incentivo das profissionais para que os alunos realizem empréstimo de livros, é ainda muito rasa a autonomia da criança para se apropriar do acervo, apesar da colaboração que o mobiliário oferece, em termos de funcionalidade.

\section{Apropriação do espaço e de seus componentes pelos alunos}

$$
2^{\circ} \text { ANOS - Grupos H, I e J: }
$$

Percebeu-se, durante as observações, que os alunos se dirigem ao espaço de maneira "ensaiada", que pode ocorrer devido ao costume de realizar atividades semelhantes neste local durante todo o ano letivo. Eles pareciam cientes do fluxo 
que deveriam assumir ao entrar na sala, para onde se dirigir e que atividades realizar. Por exemplo, ao entrarem na sala já assumiram que o próximo passo era a devolução de livros na caixa. Foi observado que a escolha dos lugares no tatame foi direcionada pelas professoras de sala de aula, que organizaram a posição dos alunos levando em consideração que eles se espalhassem pelo tatame sem formar grupos próximos. Houve também, em um dos casos, a intervenção da professora que trocou alguns alunos de lugar para que eles não conversassem durante a aula de biblioteca.

$3^{\circ}$ ANOS - Grupos K, L, M, N:

Os alunos demonstraram se sentir confortáveis em utilizar o espaço e interagir como os componentes oferecidos para as Aulas de Biblioteca, no sentido que se dirigiam direto para o acervo ou para o tatame quando direcionados para as respectivas atividades de empréstimo ou de contação de histórias. Não se pode afirmar sobre a apropriação da biblioteca pelo aluno no que diz respeito ao uso deste espaço em seu tempo livre. Desta forma, em se tratar da apropriação do espaço durante as aulas, os alunos apresentaram pleno potencial de uso, exceto pelo uso do computador, que não foi visto em nenhuma das observações.

$4^{\circ}$ ANOS - Grupos O, P, Q:

Os apontamentos que resultaram das observações realizadas com os grupos desta série são similares aos apontamentos que resultaram das observações realizadas com os grupos do terceiro ano. Deve-se acrescentar aqui que a relação das crianças observadas com a pesquisa virtual do acervo e, consequentemente, com o computador disponível na sala de aula de biblioteca demonstrou-se tímida e frágil. Era notório que as crianças sabiam que o computador servia para pesquisar o acervo, e muitos dos usuários se mostraram empolgados em realizar a pesquisa mas, ao sentar na cadeira para utilizar o computador, a linguagem corporal e as perguntas realizadas pelas crianças demonstravam que estas não dominavam o computador e nem apresentavam intimidade com o sistema de pesquisa digital, gerando frustração e desinteresse em quase todos os casos. O tempo disponível para estas pesquisas virtuais também deve ser levado em consideração, pois esta 
falta de intimidade com a pesquisa digital tornava necessário maior investimento em tempo por parte dos alunos para conclusão da atividade.

Sobre este tema, pode-se concluir que, por se tratar de aulas quinzenais que já ocorriam há meses, os alunos por um lado atuam de maneira ensaiada, no sentido de compreender as ações que precisam executar para desempenhar as atividades rotineiras das aulas de biblioteca. Neste sentido, pode-se afirmar que existe um conforto e intimidade para se apropriar dos elementos existentes no ambiente, como o tatame e as estantes, por exemplo. Não será discutido aqui a relação dos alunos com as estantes e expositores pois este tema já foi abordado no tópico anterior.

Infelizmente, não foi possível tecer uma análise acerca da relação do aluno com a Sala do Acervo da Biblioteca Beta em horários livres, pois a pesquisadora só teve acesso ao ambiente em momentos de aula de biblioteca. Desta forma, fica incompleta a análise acerca da apropriação do aluno em relação a este ambiente de maneira geral, pela impossibilidade de se coletar os dados em questão.

\section{Conforto durante as aulas assistidas}

Adianta-se que a análise feita sobre o conforto diz respeito apenas ao conforto físico dos alunos em relação à postura corporal destes durante as atividades das aulas de biblioteca, devido à não-percepção de problemas acústicos ou de temperatura (não foram observados desconfortos relativos a estes aspectos e os alunos não manifestaram problemas desta natureza durante as observações).

$2^{\circ}$ ANOS - Grupos H, I e J:

Durante as aulas observadas, os alunos permaneceram sentados com as pernas dobradas, em uma posição orientada pelas professoras de sala de aula como sendo "sentar igual a um índio". Acredita-se que esta orientação tenha sido para que todos coubessem no espaço e para que a postura colaborasse na atenção dada a aula. Não foi permitido que se deitassem no tatame durante a contação de histórias e não havia almofadas ou outro tipo de encosto para as costas. Percebeuse que os alunos mudavam constantemente de posição e foi observado também que alguns alunos faziam pequenos alongamentos no local, sobretudo para a lom- 
bar e para o pescoço involuntariamente enquanto ouviam a história contada. 0 desconforto observado não aparentou, porém, causar dispersão da atenção dos alunos para a história.

No momento em que realizaram as atividades em trio, percebeu-se que os alunos imediatamente mudaram da posição inicialmente estipulada, e a maioria deitou -se de bruços no tatame para escrever no papel dado pelas professoras. A realização de atividade escrita no tatame aparentou maior dificuldade pois era grande o esforço para escrever a lápis na folha de papel sem um suporte entre o papel e o tatame de e.v.a.

$3^{\circ}$ e $4^{\circ}$ ANOS - Grupos K, L, M, N, O, P, Q:

O grupo K, observado em 2015, apresentou uma pequena divergência dos grupos observados em 2016, devido ao acréscimo de duas estantes na parede que, anteriormente, ficava vazia e que alguns alunos utilizavam para se encostar e assistir às aulas na época em que o grupo K foi observado. Para este grupo, notouse que as crianças que faziam uso da parede para se encostar permaneciam mais atentas às aulas e mudavam menos de posição, aparentando maior conforto que as outras crianças da sala.

As turmas observadas após o acréscimo das estantes (grupos L, M e N) perderam o acesso a esta parede. Considerando-se que a sala não disponibiliza almofadas ou qualquer outro tipo de apoio para a coluna das crianças durante os 50 minutos de aula, infere-se que a questão da falta de conforto seja latente nestes casos e que também contribua para os momentos de dispersão dos alunos e de desinteresse da aula, apesar de não terem sido muitos. Não houve, nestes casos, orientação das professoras sobre como deveriam se sentar no tatame e alguns alunos até se deitaram, mas apresentavam dificuldade para enxergar a contadora de histórias e de participar das aulas, voltando para a posição sentada posteriormente.

As imagens a seguir compilam as posições mais notadas durante as observações das aulas. Adianta-se que, no geral, o conforto físico relativo à forma como os alunos se posicionam corporalmente pareceu ser afetado devido à falta de apoio para a coluna dos alunos, que eram obrigados a permanecer sentados durante as con- 
tações de história. No caso dos alunos dos grupos H, I e J, houve também a dificuldade para realizar a atividade de escrita, pela falta de apoio para o papel.

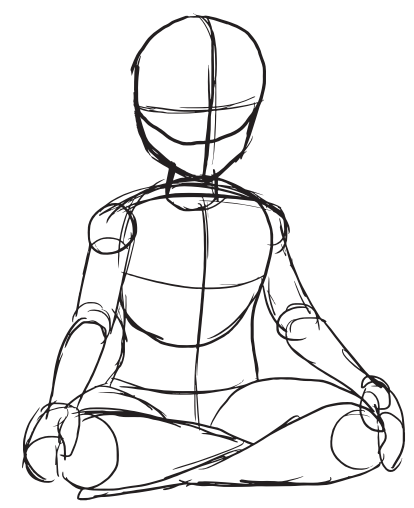

Figura 70 - Principais posições realizadas pelas crianças observadas.

Fonte:Autora

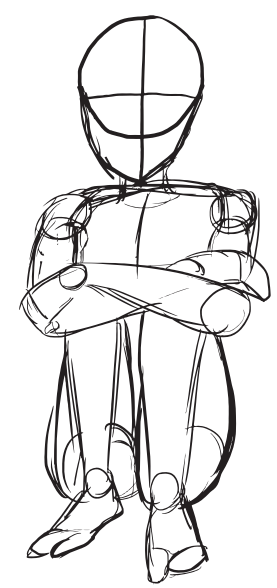

Figura 71 - Principais posições realizadas pelas crianças observadas.

Fonte:Autora

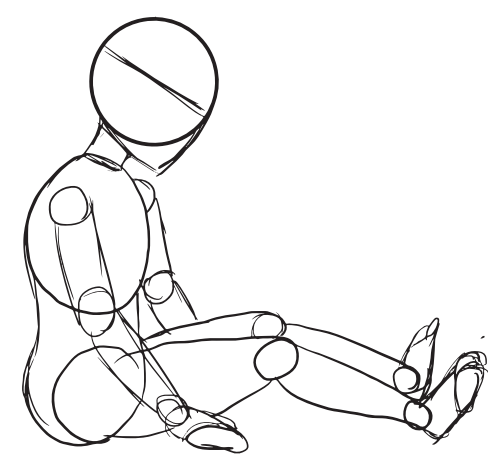

Figura 72 - Principais posições realizadas pelas crianças observadas.

Fonte:Autora
Durante alguns momentos, percebeu-se que alguns alunos sentavam-se nesta posição, com a coluna muito ereta e forçando o pescoço para baixo, por alguns segundos. este movimento reflete uma forma de alongamento do corpo, indicando cansaço e incômodo por parte do aluno.

Outra posição dos alunos que apoiavam as costas na parede lateral disponível na sala. Os alunos passavam poucos minutos sentados assim.

os poucos alunos (entre 3 e 5) que conseguiam apoiar as costas na parede, permaneciam assim por muito tempo 


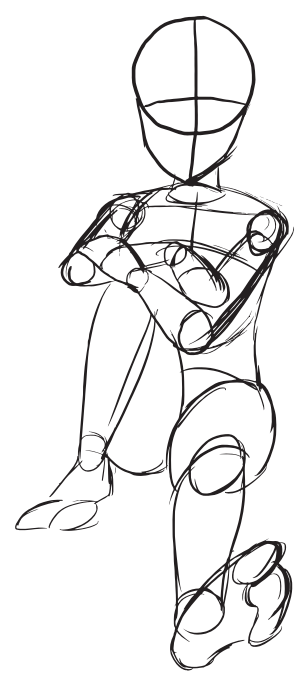

Figura 73 - Principais posições realizadas pelas crianças observadas.

Fonte:Autora

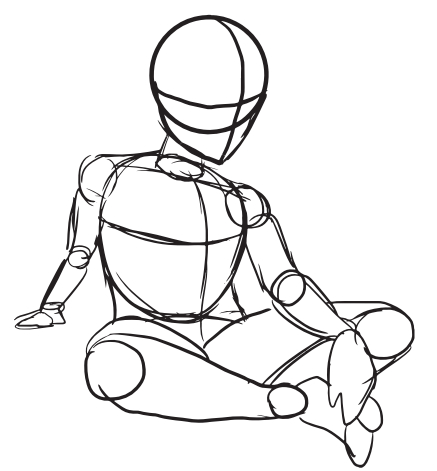

Figura 74 - Principais posições realizadas pelas crianças observadas.

Fonte:Autora

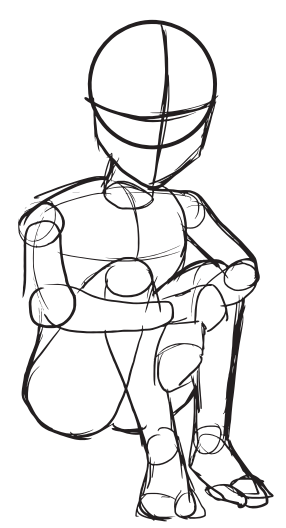

Figura 75 - Principais posições realizadas pelas crianças observadas.

Fonte:Autora
Dentre as formas que os alunos se encostaram na parede, esta pareceu ser a mais confortável, porque alguns alunos passaram quase todo o tempo disponível da aula de biblioteca sentados assim.

Poucos alunos testaram esta posição, mas não se demoravam, pois apoiar o peso do corpo em um dos braços desta forma força o punho do braço em questão.

Muitos alunos se sentaram assim, mas por pouco tempo. também observou-se que esta posição tinham um caráter de alongamento da coluna 


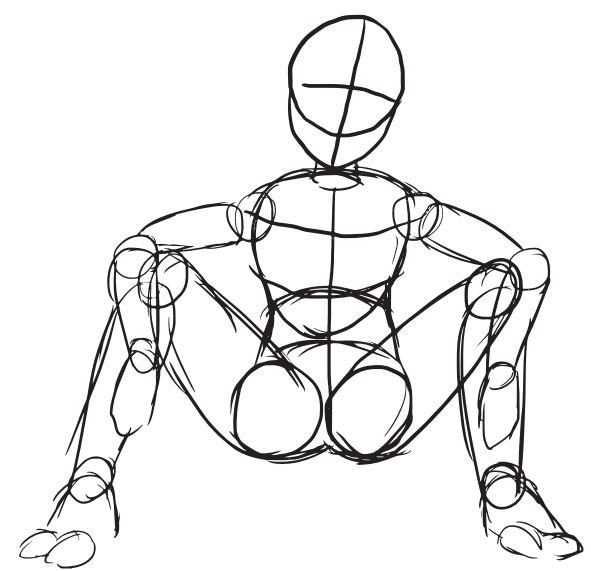

Figura 76 - Principais posições realizadas pelas crianças observadas.

Fonte:Autora

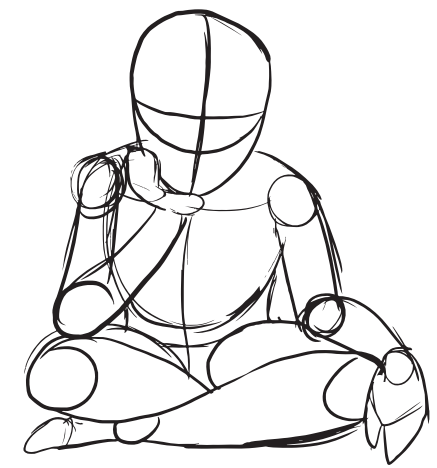

Figura 77 - Principais posições realizadas pelas crianças observadas.

Fonte:Autora

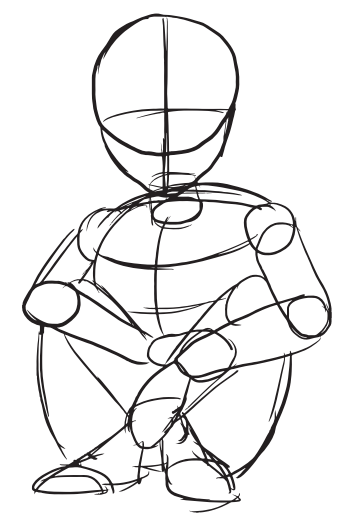

Figura 78 - Principais posições realizadas pelas crianças observadas.

Fonte:Autora
Alguns alunos passaram poucos minutos nesta posição. acredita-se que a dificuldade em sustentar o peso do corpo nesta situação impedia que continuassem sentados assim.

Esta postura foi bastante observada nos alunos que não tiveram acesso à parede para encostar a coluna. acredita-se que devido a possibilidade de descansar o peso do tronco no braço apoiado na coxa estimulava a permanência nesta posição.

Muitos alunos se sentaram assim, mas por pouco tempo. também observou-se que esta posição tinham um caráter de alongamento da coluna. 
Os alunos que tentaram permanecer assim, logo mudavam de posição, pois a falta de apoio para as costas dificulta sentar desta forma por muito tempo.

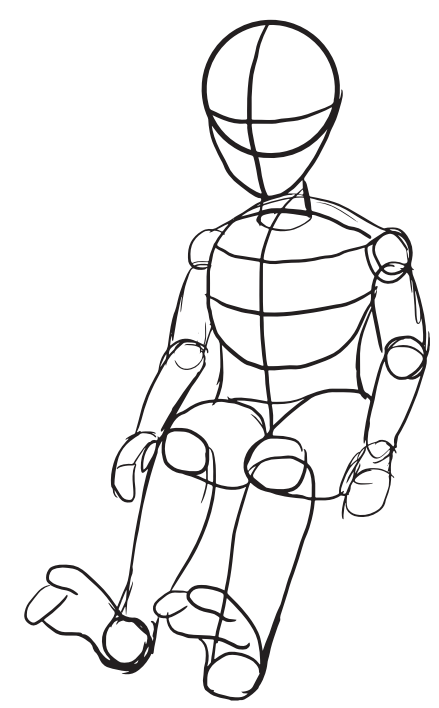

Figura 79 - Principais posições realizadas pelas crianças observadas.

Fonte:Autora

\section{Relação com os equipamentos e mobiliários}

$2^{\circ}$ ANOS - Grupos H, l e J:

Basicamente, os únicos mobiliários com os quais o usuário se relacionou de fato foram as estantes, os expositores e o tatame. Desta forma, foi observado e relatado que, no que diz respeito aos expositores, algumas crianças de menor estatura apresentaram dificuldades em alcançar os livros nas prateleiras mais altas, fato relatado com mais precisão na categoria "1. Acesso do aluno ao acervo disponível". Já em relação ao tatame, observou-se que os alunos pisavam no mesmo espaço onde, posteriormente, deitavam de bruços e seus rostos entravam em contato com o espaço sujo, o que pode vir a acarretar em doenças ou desenvolver alergias.

$3^{\circ}$ ANOS - Grupos K, L, M, N:

As estantes e os expositores se mostraram adequados em relação à altura das crianças e não demonstraram oferecer risco de acidentes. Percebeu-se que a relação dos usuários com estes mobiliários envolvia fortemente características de usabilidade bem resolvidas. Já em relação ao tatame, deve-se apontar as mesmas preocupações concernentes às observações com os grupos das segundas séries: os alunos acessavam o tatame calçados e foram vistos encostando o rosto (e em alguns casos a boca) no mesmo equipamento posteriormente, correndo o risco 
de desenvolver alergias ou de ser alvo de doenças, pela exposição à sujeira. Além disso, os tatames se conectam a partir do encaixe dos módulos e foi observado que algumas crianças puxavam os módulos para cima, enquanto assistiam às aulas, correndo o risco de danificar o material.

$4^{\circ}$ ANOS - Grupos O, P, Q

Sobre este aspecto, os apontamentos que foram feitos para os grupos das segundas e terceiras séries também se aplicam aqui. O que deve ser acrescentado é a relação com a mesa e a cadeira utilizados para pesquisar no computador da sala, que só pôde ser observado com alunos da quarta série. As crianças que fizeram pesquisa no computador e que, consequentemente, utilizaram a mesa e a cadeira, não demonstraram nenhuma dificuldade ao utilizar estes mobiliários. No que diz respeito à funcionalidade, estes equipamentos aparentaram atender às necessidades do usuário.

Sobre este tópico conclui-se que o uso do tatame de e.v.a. responde bem à necessidade de assento no sentido de comportar bem os alunos e de ser um equipamento com pouco desgaste em relação à quantidade de vezes que é utilizado por dia. Por outro lado, como relatado anteriormente, este equipamento acaba por ser pouco higiênico, considerando-se que os alunos realizam ali atividades calçados e foi observado que colocam o rosto, e até mesmo a boca, no tatame. Além disso, acredita-se que o tatame apenas não é suficiente para suprir as questões de conforto corporal dos alunos.

Percebe-se que, na Biblioteca Beta, os mobiliários foram comprados e/ou projetados pensando-se sobretudo na funcionalidade dos mesmos em relação à capacidade de executar as atividades às quais as aulas de biblioteca se propõem. Estes equipamentos deixam a desejam no quesito conforto, alcance (no caso dos expositores para algumas crianças) e ludicidade.

\subsection{Storytellings}

Os storytellings foram aplicados com alunos que frequentaram a Biblioteca Beta e que se encontravam entre o segundo e o quarto ano do Ensino Fundamental, por estarem na faixa etária que interessa a esta pesquisa. 
Considerando-se a impossibilidade de se aplicar a atividade na biblioteca, por que o cronograma das aulas de biblioteca não permitiam, foi pedido aos pais ou responsáveis que direcionassem a atividade às crianças em casa no tempo livre dos alunos. $\mathrm{O}$ documento enviado instruindo adultos sobre o processo do storytelling encontra-se no Apêndice desta pesquisa.

Os resultados da aplicação das storytellings com os alunos foram obtidos a partir das análises das representações gráficas e das frases produzidas pelas crianças. Buscou-se agrupar em categorias de interesse para a pesquisa os aspectos que mais incidiram nos desenhos.

No total, houve o retorno de 70 storytellings, divididos da seguinte maneira: Apenas desenhos - 50 unidades

Apenas frases ou redações - 5 unidades

Ambos desenhos e frases - 15 unidades

Apesar da avaliação geral dos documentos ter sido feita independentemente da série em que se encontram estas crianças, registra-se a seguir a quantidade de storytellings obtidos divididos por série, pois esta classificação colaborou no entendimento de certos fenômenos percebidos durante a análise dos documentos.

\begin{tabular}{|c|c|}
\hline QUADRO 25 - QUANTIDADE DE STORYTELLINGS OBTIDOS \\
\hline Série & Quantidade de Storytellings \\
\hline $2^{\circ}$ ano & 22 unidades \\
\hline $3^{\circ}$ ano & 14 unidades \\
\hline $4^{\circ}$ ano & 24 unidades \\
\hline Sem identificação & 10 unidades \\
\hline
\end{tabular}

Fonte: Autora

A seguir, as categorias que foram identificadas durante a análise dos dados:

- Ludicidade

Durante a análise dos storytellings, os traços de ludicidade que buscou-se encontrar nos desenhos e nas falas das crianças apoiaram-se na presença de brincadeiras, jogos, propostas voltadas para o lazer e para a diversão, atividades que remetessem à fantasia e ao contato com o outro. A expressão do desejo de cores e de objetos decorativos, para além do que se está acostumado a ver em bibliotecas 
escolares, também foi levada em consideração na análise dos documentos.

A figura a seguir expõem os principais aspectos lúdicos encontrados nos storytellings:

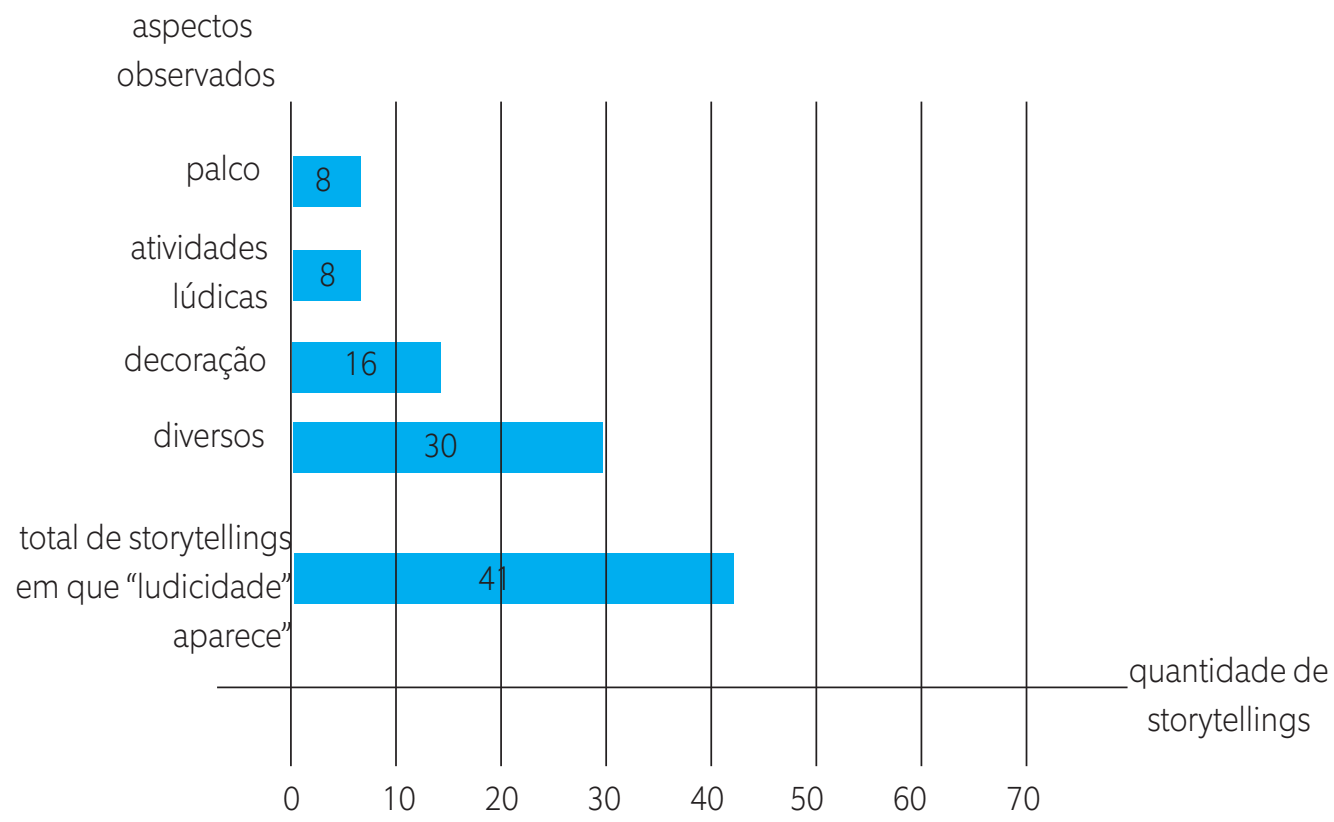

Figura 80 - Síntese gráfica da ludicidade nos storytellings Fonte:Autora

Os aspectos lúdicos apresentados na Figura 80 podem ou não ser encontrados no mesmo storytelling, ou seja, o gráfico apenas separa os aspectos para fins de análise, não significando que eles não possam se combinar entre si. Os números no gráfico representam o número de vezes, em unidade, em que o aspecto em questão se manifestou.

Os principais motivos referentes à ludicidade que foram encontrados nos documentos levam à percepção de que em todas as séries houve forte presença de aspectos lúdicos, que se assemelham nos grupos da mesma série. Por exemplo, o palco esteve presente em um terço dos desenhos de crianças dos $4^{\circ}$ anos, porém não apareceu em nenhum desenho ou redação de crianças em outras séries, o que leva à conclusão que este padrão pode estar relacionado a trabalhos ou projetos realizados por crianças desta série, que talvez tenha levado à necessidade de expressarem o desejo de um palco na biblioteca, para representar ou para dar destaque às pessoas que estejam contando a história. 
Motivos decorativos, como plantas, jarros e ornamentos também estiveram presentes nos desenhos das crianças dos $4^{\circ}$ anos que estão em sua maioria com nove anos de idade, o que pode colaborar para uma capacidade de compreensão maior do entorno, em comparação com crianças de sete e de oito anos, dando ao desenho maior detalhamento e precisão em relação aos seus desejos e necessidades.

Já as crianças dos $2^{\circ}$ e $3^{\circ}$ anos trouxeram a expressão da ludicidade com os jogos de tabuleiro, indicando que a biblioteca pode ser um espaço para além da leitura e do livro. Além disso, foram desenhados gibis e truques de mágica por alunos dos $2^{\circ}$ anos, que também apontam para a visão da biblioteca como um ambiente de múltiplas capacidades de lazer e entretenimento.

- Conforto

Os aspectos referentes ao tema "Conforto" que mais se repetiram e que merecem destaque, estão evidenciados na figura a seguir:

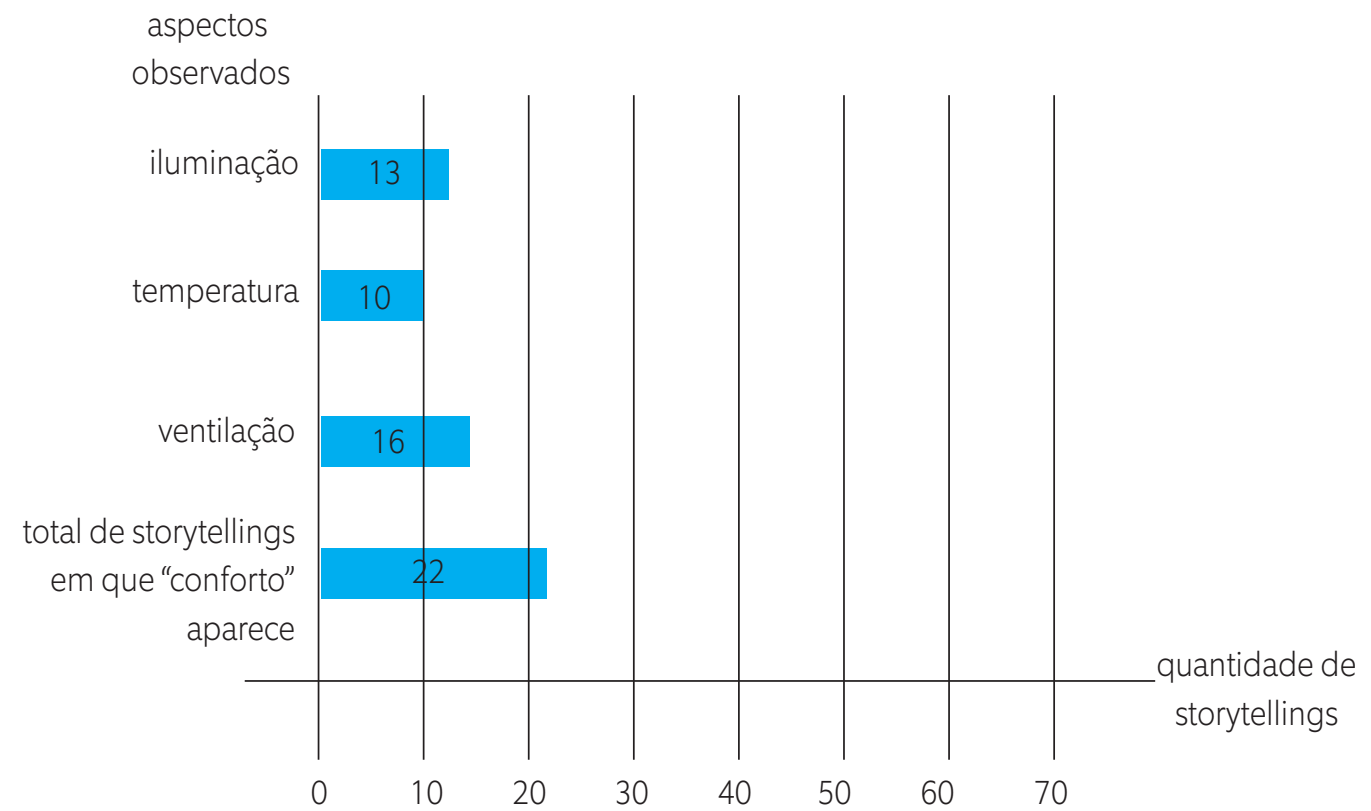

Figura 81- Síntese gráfica do conforto nos storytellings Fonte:Autora 
Os aspectos de conforto apresentados na Figura 81 podem ou não ser encontrados no mesmo storytelling, ou seja, o gráfico apenas separa os aspectos para fins de análise, não significando que eles não possam se combinar entre si. Os números no gráfico representam o número de vezes, em unidade, em que o aspecto em questão se manifestou.

Foram levados em consideração apenas aspectos térmicos e de iluminação no que se entende por tópicos referentes ao nível de conforto do ambiente construído. Isto porque outros aspectos como acústica e conforto visual não puderam ser avaliados nos storytellings obtidos. Além disso, o conforto corporal que pode ser obtido por meio da análise do mobiliário será observado no subtópico "Mobiliários e Equipamentos", que tece análises acerca deste fator.

No quesito "lluminação", foram considerados os storytellings que mencionavam com palavras ou com representações gráficas: janelas, lâmpadas, lustres e abajures. Dos 13 storytellings que continham este aspecto, 7 foram realizados por crianças do $2^{\circ}$ ano, e eram, em sua maioria, janelas. Considerando-se que 7 storytellings significa aproximadamente um terço do total de storytellings obtidos por crianças do $2^{\circ}$ ano, pode-se considerar que é um evento a ser levado em consideração na análise dos mesmos. Acredita-se que esta incidência do desenho de janelas deu-se porque é o primeiro ano destas crianças na Biblioteca Beta e, como as cortinas da Sala de Contação de Histórias desta biblioteca geralmente encontra-se fechada, as crianças perdem o contato com a luz natural durante as aulas de biblioteca. Além disso, muitas destas crianças tiveram aula na Biblioteca Alfa no ano anterior, onde as aulas de biblioteca se dão num ambiente em que a janela fica muito próxima do tatame onde as crianças assistem às aulas. Desta forma, é natural que fique o apelo e a lembrança da janela enquanto parte da biblioteca.

O aspecto "temperatura" está evidenciado porque observou-se a presença do ar-condicionado em 10 dos 70 storytellings. Destes, 9 foram desenhos feitos por alunos do $4^{\circ}$ ano. As janelas não foram inseridas no aspecto "temperatura" porque as aulas de biblioteca acontecem com as janelas da Sala de Contação de História fechadas e geralmente com a cortina fechada. Portanto, apenas os ar-condicionados foram levados em consideração neste quesito. Deve-se investigar mais profundamente as possíveis razões para o ar-condicionado se manifestar em uma quantidade significativa. 
- Mobiliários e Equipamentos

Os Mobiliários e Equipamentos que mais se repetiram e merecem destaque, estão evidenciados na figura a seguir:

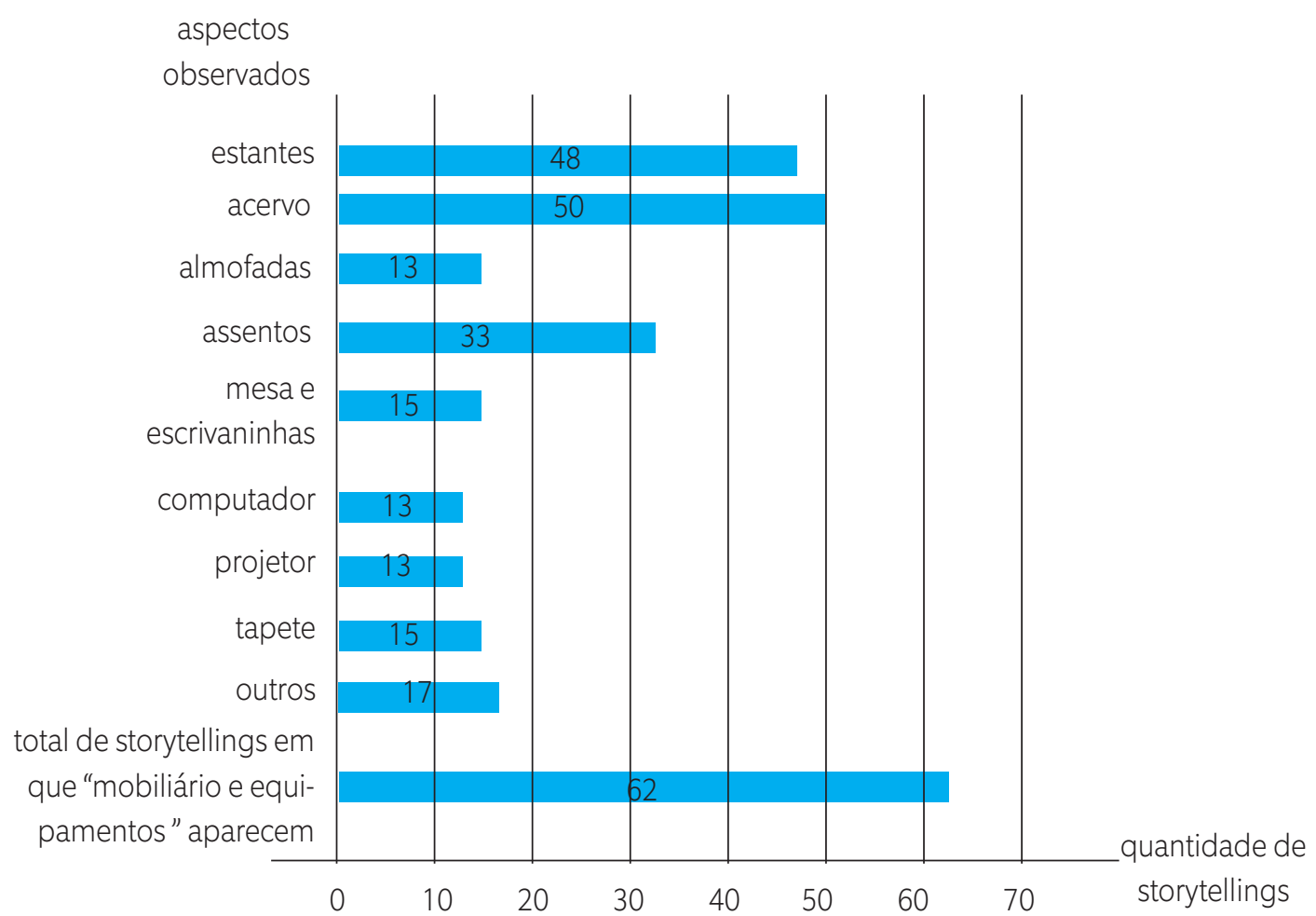

Figura 82- Síntese gráfica dos mobiliários e equipamentos nos storytellings. Fonte:Autora

Os mobiliários e equipamentos apresentados na Figura 82 podem ou não ser encontrados no mesmo storytelling, ou seja, o gráfico apenas separa os aspectos para fins de análise, não significando que eles não possam se combinar entre si. Os números no gráfico representam o número de vezes, em unidade, em que o aspecto em questão se manifestou.

O que se pode depreender de mais significativo nas menções aos mobiliários e equipamentos ou nas representações gráficas dos mesmo nos storytellings é a presença de livros (classificado na Figura 82 como "acervo") na grande maioria dos storytellings. Além disso, as estantes aparentam ser a alternativa que as crianças conhecem para armazenamento dos livros. Em todos os storytellings em que houve a presença de estantes, exceto por um, as estantes são representadas de maneira tradicional e, em sua maioria, similares às estantes da Biblioteca Alfa. 
Além disso, nota-se que a grande maioria dos objetos citados nesta categoria são os mesmo já presentes na Biblioteca Alfa. Exceto pelos itens "mesa e escrivaninha”, todos os outros ítens da Figura 82 podem ser encontrados na Sala de Contação de Histórias da Biblioteca Beta, refletindo a familiaridade das crianças com o ambiente em questão.

Um aspecto identificado com a análise dos storytellings é a menção e/ou representação de mesas e assentos, que indicam que a criança sente necessidade de outros mobiliários compondo o ambiente em questão, seja para realizar atividades específicas que necessitam de mesa e cadeira ou apenas porque enxergam que estes mobiliários são necessários para a biblioteca escolar.

Ainda sobre os assentos, estes foram retratados de diversas maneiras: cadeiras, sofás, bancos e, principalmente, puffs. Acredita-se que os alunos estejam assim expressando a necessidade do assento para a contação de histórias, por se tratar do momento em que elas frequentam a biblioteca. Considerando-se que o tatame é onde elas se sentam durante as aulas de biblioteca, foi importante notar que algumas crianças inseriram adjetivos ou classificações para o tapete que desenharam na biblioteca ideal, como "um tapete fofinho" ou "um tapete de veludo", mais uma evidência do apelo para o conforto. 


$$
\begin{aligned}
& \text { CAPÍTULO } 5 \\
& \text { CONCLUSÕES E } \\
& \text { CONSIDERAÇÕES }
\end{aligned}
$$




\section{1 - CONCLUSÕES E CONSIDERAÇÕES}

Após a realização dos estudos de caso nas bibliotecas Alfa e Beta do Colégio X e na Biblioteca Infantojuvenil Monteiro Lobato (BIJML), com a análise dos resultados obtidos após coleta e tratamento dos dados de cada um dos stakeholders investigados, foi possível confrontar estes resultados com as informações presentes no Capítulo 3, referentes ao Estado da Arte dos mobiliários oferecidos pela indústria e com a organização espacial de bibliotecas infantis consideradas referências por premiação no mundo, buscando investigar a situação das bibliotecas dos estudos de caso em relação ao que se pode encontrar na indústria brasileira e nas bibliotecas consideradas referência.

Além disso, baseando-se no conteúdo presente no Capítulo 2 que envolve o referencial teórico no qual se debruça este estudo, também foi possível buscar elementos que apontem se as bibliotecas Alfa, Beta e BIJML podem ser consideradas apropriadas em relação ao conceito de Infoeducação e os aspectos a ele imbricados.

As considerações foram divididas em tópicos, onde se encontrarão os estudos de caso, por meio de uma triangulação de dados que envolve os conceitos relativos ao campo do conhecimento da Infoeducação, o Estado da Arte dos mobiliários e equipamentos voltados para escolas e bibliotecas e os resultados obtidos com dados colhidos com os stakeholders de cada uma das bibliotecas. 
A seguir, os tópicos que norteiam as análises finais deste trabalho:

- O espaço, sua organização e os equipamentos que o compõem - onde foi levado em consideração se o ambiente está em harmonia com as recomendações técnicas pertinentes ao mobiliário presente e a seus equipamentos, os Parâmetros de Projeto utilizados para analisar bibliotecas no capítulo 3 e a organização espacial de acordo com as atividades ali executadas. Aqui foi levada em consideração também a mudança de ambientes e de mobiliários da Biblioteca Alfa, que trouxe apontamentos acerca das diferenças que ocorreram na dinâmica do usuário com o espaço e com as atividades ali realizadas.

- A biblioteca e seu usuário - leva em consideração a forma como o usuário enxerga a biblioteca e como gostaria que fosse, em relação as bibliotecas Alfa e Beta, onde foi possível ter acesso a este tipo de dado por meio dos storytellings aplicados com as crianças e com a observação dos alunos durante as aulas de biblioteca. Para a BIJML foram levadas em consideração as respostas ao questionário aplicado para tecer análises sobre a opinião do usuário em relação ao ambiente e seus equipamentos.

- O papel da biblioteca: educação e cultura - aqui buscou-se compreender como as gestoras enxergam a biblioteca na qual trabalham, levando em consideração sua responsabilidade na configuração da biblioteca e na disposição de seus equipamentos, as atividades ali realizadas e, a partir das observações feitas pela pesquisadora do uso do local, compreender as implicações que tornam ou não estas bibliotecas dispositivos culturais, de acordo com os preceitos da Infoeducação.

\section{1 - O espaço, sua organização e os equipamentos que o compõem:}

\section{Biblioteca Infantojuvenil Monteiro Lobato}

Devido a fatores relacionados à gestão de ambientes públicos, a organização da Sala do Acervo Infantil da BIJML e seus mobiliários dependem de questões que vão além da vontade da bibliotecária responsável e da diretora da biblioteca. Considerando-se o tombamento do prédio, que impede mudanças estruturais no 
ambiente e a compra do mobiliário estar relacionada ao processo de licitação, é complicado responsabilizar os gestores do local acerca das falhas pertinentes ao ambiente.

Sobre aspectos lúdicos, a BIJML, por ter como tema seu patrono e, em especial, o Sítio do Pica-Pau Amarelo, investe nestes temas para criar um ambiente divertido para as crianças, mas com intenções de preservar a cultura relacionada ao nome da biblioteca. Desta forma, restringe as possibilidades de se aplicar a ludicidade no local. Em comparação às bibliotecas observadas no Capítulo 3 desta dissertação, que investe em cores, mobiliários ousados e formas espaciais diversas, a BIJML permanece na mesmice de investir em desenhos e grafismos para aplicar a ludicidade no local.

Sobre a organização do espaço, na qual ocorre a divisão do ambiente para públicos distintos apenas com a organização dos mobiliários e equipamentos, conclui-se que é importante que crianças de idades distintas utilizem do mesmo espaço, que convivam. Porém, deve-se haver também o mínimo de certeza sobre cuidados com acidentes que podem vir a acontecer neste tipo de relacionamento. Como exemplo, crianças de um ano brincando no mesmo tatame que crianças de nove, pode levar a um acidente. Notou-se que a bibliotecária busca organizar o espaço de forma a melhor atender a todos os usuários, porém recomenda-se investigar outras possibilidades de layout para a sala. Além disso, é aparente o distanciamento proposital das estantes, cujo acervo é proibido para as crianças mexerem sozinhas, evitando que isto aconteça. Desta forma, as crianças ficam limitadas a pedir ajuda para encontrar o livro que desejam ou se conformar em ler o que os expositores apresentam, diminuindo seu protagonismo no uso do espaço.

Além disso, foi verificado que o mobiliário deste ambiente é bastante similar ao oferecido pela indústria brasileira, justificado pela compra por meio de licitação, que impede um projeto único para esta biblioteca. Os móveis que compõem este ambiente não dialogam entre si, são peças que chegam em épocas distintas, tornando o ambiente complexo e destoante.

As mesas e cadeiras além de não dialogarem entre si, em termos de forma e estética, não servem para crianças com mais de oito anos, o que inviabiliza o uso destas peças, por mais que algumas crianças ainda insistam em fazê-lo. 
É necessário rever também o tatame de e.v.a. como alternativa para assento, porque as crianças pisam neste equipamento, onde bebês engatinham e as próprias crianças apoiam o rosto e a boca, podendo acarretar em doenças.

Sobre os parâmetros sugeridos por Kowaltowski no Capítulo 3, concluise que a sala abriga alguns desses parâmetros, porém deixa a desejar em outros, como é o caso do uso da tecnologia pela criança e do mobiliário confortável para sentar.

É necessário reorganizar a Sala do Acervo Infantil da BIJML de modo que os mobiliários e equipamentos além de dialogar entre si e fazer sentido esteticamente, atenda da melhor maneira possível a seu público tão variado.

\section{Colégio X:}

Observou-se que em ambas as bibliotecas do Colégio X, em especial a Biblioteca Beta, a grande questão que move a organização do espaço e a compra do mobiliário ali presente é o de praticidade para realizar as tarefas durante as aulas de biblioteca.

No caso da Biblioteca Beta, a ludicidade quase não está presente, se não por meio de poucos grafismos aleatórios nas paredes e nas cores fortes e alegres do tatame.

Sobre o mobiliário, este também não dialoga entre si. Apesar das estantes terem sido feitas por encomenda, ela não se comunicam visualmente com os expositores e com o mobiliário voltado para o uso do computador (mesa e cadeira).

É preciso também repensar o tatame como única forma de assento nesta Sala, pois as observações dos alunos nas aulas apontaram para um grande desconforto corporal, além da interpretação dos storytellings, onde as crianças pediam por um ambiente mais confortável, principalmente relacionado ao assento.

Sobre os parâmetros sugeridos por Kowaltowski, ficam a desejar em relação ao uso da tecnologia, mobiliário confortável para sentar, a linguagem arquitetônica que expresse os valores da escola e os alunos poderem se movimentar livremente.

\section{Biblioteca Alfa:}

É possível fazer uma comparação entre a situação da Biblioteca Alfa em 
2015 e 2016 pela completa mudança de organização dos espaços e dos mobiliários para atender às crianças.

Com a criação de uma sala apenas para as aulas de biblioteca, o local voltado para o acervo ganhou repaginação completa: a reorganização do espaço permitiu a criação de um expositor que abrange grande área da sala, permitindo que as crianças localizem o livro pela capa, dando-Ihes autonomia. Além disso, as novas estantes altas permitem guardar parte do acervo caso seja preciso. O novo armário para uso das funcionárias dialoga em seu material com os outros mobiliários, além de que as portas de correr permitiram melhor uso do espaço em questão.

Sobre a sala de contação de histórias, agora as crianças conseguem participar das atividades com mais conforto e inclusive realizar atividades e brincadeiras que o tamanho do espaço anterior não permitia.

Em ambas as salas e em ambos os anos, o fator ludicidade ficou a cargo de grafismos que remetem a histórias de princesas ou animais, que não dialogam entre si e que não unificam a biblioteca em um tema. Acredita-se que é de grande importância não só apresentar outras propostas de assento para estas crianças, que não apenas o tatame, mas também trabalhar a ludicidade no espaço em questão de outras maneiras, que dêem ao ambiente uma identidade própria e torne-o mais convidativo ao público em questão.

\section{2 - A biblioteca e seu usuário}

\section{Colégio X:}

Depreendeu-se, após os resultados obtidos com a análise dos dados coletados, em especial com as crianças, que não há dúvidas da boa relação da criança com as aulas de biblioteca ofertadas pela escola, bem como com as funcionárias envolvidas nesta atividade.

A análise dos storytellings feitos pelas crianças que frequentam a Biblioteca Alfa trouxe resultados que apontam para o fato de que a criança parece enxergar a biblioteca, em termos de organização espacial, muito similarmente à própria Biblioteca Alfa, acredita-se que por esta ser sua principal referência de biblioteca. Além disso, muitas crianças expressaram o desejo de maior conforto em relação à biblioteca, por meio do desenho de assentos ou de adjetivos que enaltecem essa 
característica. Uma análise importante que se fez sobre o tema é que estas crianças demonstraram, por meio do storytelling, compreender que a biblioteca é mais que um espaço de leitura, é um ambiente lúdico e de lazer.

Em relação às observações da pesquisadora, compreende-se que as crianças se comportam de uma maneira ensaiada, devido à sua rotina de comparecer quinzenalmente naquele espaço, sabendo exatamente o que devem fazer quando entram no local e para onde se dirigir. Esta forma de se comportar não diminui a importância de seu uso do espaço, mas restringe, no sentido que ficam limitados a escolher livros dos expositores previamente selecionados e a realizar apenas as atividades sugeridas durante as aulas.

Quando aos alunos da Biblioteca Beta, as análises apontam para uma reflexão maior por parte dos alunos das possibilidades que a biblioteca pode vir a oferecer, tanto em relação às atividades quanto aos mobiliários e equipamentos. Os alunos apresentaram questões referentes também à temperatura do local e, sobretudo, pareciam pedir por mais conforto em diversos tipos de assentos, reforçando que as posições observadas pelos alunos durante as aulas de biblioteca indicam que eles realmente não estão confortáveis em passar todo o tempo desta aula no tatame. Estes alunos expressaram também necessidades de ludicidade em seus desenhos, principalmente com a sugestão de se colocar um palco na sala de contação e de jogos de tabuleiro, mostrando também que eles vêem a biblioteca como um local de diversão e lazer, para além das obrigações de aulas.

As observações da pesquisadora levam à conclusão que estes alunos, apesar de sentirem muito prazer em participar das aulas de biblioteca e de, em sua maioria, não ter problemas para alcançar o acervo nas estantes e expositores, poderiam se apropriar melhor do local, pois as aulas de biblioteca acabam restringindo seu potencial de ocupação do espaço e de exploração do acervo.

\section{Biblioteca Infantojuvenil Monteiro Lobato}

Sobre a relação do usuário com esta biblioteca, remetendo-se aos grupos escolares, conclui-se que, apesar de se sentirem bem no local a ponto de ter intimidade para explorar o lugar, durante a contação de histórias os alunos não estavam confortáveis no tatame, devido ao pouco espaço para se distribuírem. Não se pode 
depreender muito sobre essa relação, pelo breve momento que estas crianças passavam no local, além do tipo de atividade (que coloca um grande número de crianças conhecidas no espaço com um tema de visita guiada) que não permite que a criança explore o local por quanto tempo ela quiser, nem realizar empréstimo dos livros, por exemplo, tornando a biblioteca, neste caso, apenas mais um local de passeio escolar.

Sobre as crianças que frequentaram a biblioteca com seus responsáveis, a quantidade de respostas e sua diversidade aponta para o fator de socialização inerente à biblioteca, quando as crianças respondem que gostam de fazer amigos e de ler com os pais. Pelo que se pode compreender com as observações e a pergunta dirigida à criança no questionário, a criança até compreende a importância de se visitar a biblioteca, por diversas razões, e que não se mostrou tímida em utilizar o espaço e seus equipamentos, mas que se deve ressaltar a importância do acesso do usuário a todo o acervo da sala, pois parte dele fica restrito devido ao problema de desorganização do acervo pelas crianças. Aponta-se, aqui a necessidade de se estabelecerem soluções espaciais ou de sinalização voltadas para o público atendido, para que ele possa ter autonomia em relação ao uso do acervo e se apropriar melhor do local.

\section{3 - O papel da biblioteca: educação e cultura}

\section{Biblioteca Infantojuvenil Monteiro Lobato (BIJML)}

A BIJML é um caso particular em relação às bibliotecas públicas infantis no Brasil, devido a carga história que a acompanha e que também influencia, inclusive, porque o prédio é tombado, em como poderia ser organizado. Considerada à época de sua criação uma referência nacional em biblioteca infantil é, ainda hoje, um espaço com valor simbólico, devido a sua relação com a própria história da transformação da Cidade de São Paulo enquanto centro econômico e cultural no país. Desta forma, além de seu valor histórico, a biblioteca conta com um dos maiores acervos infantis de literatura da América Latina.

Infelizmente, verificou-se que a programação cultural ofertada pela biblioteca em questão vem diminuindo cada vez mais, de acordo com os profissionais entrevistados, devido ao corte de verbas para a cultura e educação. 
Esta diminuição acerca das possibilidades de atividades a serem realizadas na BIJML enfraquece sua qualidade em termos de dispositivo cultural do ponto de vista da Infoeducação, que prevê espaços multifuncionais em termos de organização mas também de informações e atividades, considerando-se que a biblioteca contemporânea deve ser um espaço que abriga diversos tipos de saberes e fazeres.

Sobre as informações pertinentes à autonomia da bibliotecária e como sua atuação influencia na qualidade das atividades realizadas, conclui-se que esta tempo pouco ou nenhum poder de decisão acerca da programação referente às atividades realizadas na biblioteca, especialmente na Sala do Acervo Infantil e da Primeira Infância, espaço no qual esta pesquisa se focou. Desta maneira, sua opinião pessoal sobre a importância da biblioteca pública infantil para a formação social, de caráter e educacional da criança serve para sua atuação com o público, não se refletem nas decisões referentes a gestão da biblioteca, que não são de sua responsabilidade. Isto porque, devido ao seu tamanho e complexidade, a BIJML conta com o trabalho de diversos gestores, bibliotecárias, funcionários e diretora, que respondem à prefeitura da cidade de São Paulo, o que diminui sua autonomia de tomada de decisão em relação à biblioteca.

Com as observações realizadas pela pesquisadora no momento das visitas dos grupos escolares, pôde-se chegar à conclusão que estas são de extrema importância para inserir crianças de diversas partes da cidade no cenário cultural local. Sabe-se que a Biblioteca recebe grupos escolares de diversas partes da cidade, de escolas públicas e privadas e diferentes faixas etárias, o que aumenta ainda mais a importância deste momento na formação cultural e educativa da criança.

No entanto, pode-se dizer em relação ainda aos grupos escolares observados que nenhuma daquelas crianças havia visitado a BINML antes, anunciando a fragilidade do acesso do público acerca daquele local. As crianças se mostraram maravilhadas com as contações de histórias realizadas pelas bibliotecárias, ainda que em um espaço muito pequeno e visivelmente desconfortável para o número de alunos recebidos, o que evidencia a necessidade e a importância deste tipo de atividade na vida da criança.

Sobre os momentos de leitura livre, fica a conclusão que as crianças busca- 
ram aproveitar ao máximo aquele momento, interagindo com o acervo e com seus colegas de classe. O papel da biblioteca enquanto agente socializador da criança fica comprovado e evidenciado quando se observa a preferência de grande parte das crianças em ler com os colegas ou compartilhar as histórias com suas professoras.

Ressaltando-se o caráter qualitativo desta pesquisa, não se pode generalizar os resultados obtidos com o questionário aplicado com os pais ou responsáveis que levavam as crianças à BIJML, no entanto, os resultados gerados após a análise das resposta podem levar a indicadores acerca do papel desta biblioteca na vida privada da criança:

Pelas respostas obtidas existe um público fiel à biblioteca, que a visita com certa frequência, ponto importante para validar que, apesar do que foi observado com os grupos escolares, algumas crianças são frequentadoras relativamente assíduas. Apesar disto, foi observado que apenas uma criança se envolveu com a atividade de empréstimo dos livros, o que faz questionar se um dos papéis da biblioteca pública, que é o de empréstimo do acervo para a população, de fato acontece.

As diversas razões que levam as crianças a visitar a biblioteca reforçam as múltiplas utilidades da biblioteca infantil e a menção por parte de alguns pais que levaram as crianças à biblioteca por se tratar de um passeio gratuito reforça a importância de se ter espaços públicos culturais e educativos de lazer voltados para o público infantil. Outros pais responderam que estavam visitando a biblioteca porque as próprias crianças pediram, exibindo-se, assim, traços de prazer por parte das crianças em visitar o local.

Sobre o papel da Biblioteca Infantojuvenil Monteiro Lobato enquanto biblioteca de caráter público voltada para crianças, conclui-se que é inegável seu valor simbólico e histórico para São Paulo, por ter servido de referência para bibliotecas infantis e escolares em todo o país, além de seu papel para a cultura e para a criança na época de sua criação.

Em relação às atividades da Sala do Acervo Infantil e da Primeira Infância, na vida das crianças observadas é que existe uma deficiência de conhecimento do que é a biblioteca pública infantil por parte dos cidadãos que residem na cidade de São Paulo, levando a um número menor de visitas do que o prédio pode comportar. Devido à falta de investimento na oferta de atividades para crianças no local, 
a biblioteca diminui seu caráter de dispositivo cultural com suas possibilidades de oferecimento de saberes de diversos tipos.

O público analisado para esta pesquisa se mostrou amplamente à vontade no espaço em questão, no sentido de se apropriar fisicamente do acervo e do mobiliário e de participar ativamente das atividades propostas, o que enfatiza ainda mais o caráter de preocupação em relação ao potencial desta biblioteca, que fica diminuído devido a fatores relacionados ao investimento em diversidade de atividades para o local.

Referente ao uso de equipamentos eletrônicos na biblioteca em questão, o fato de não existir previsão para a inserção deste tipo de tecnologia no local voltado para uso das crianças, reforça a necessidade de se repensar a biblioteca, considerando-se que estes equipamentos, como o computador e o tablet, são formas de se obter informação que estão sendo negadas aos usuários do local.

Desta forma, conclui-se que a Biblioteca Infantojuvenil Monteiro Lobato permanece um símbolo e uma referencia nacional para bibliotecas de mesma natureza, mas que necessita de reavaliação não só de seu modelo sócio-cultural como também de investimento para que a população venha a saber da existência da biblioteca, isto dito devido ao pouco fluxo de usuários no local nos períodos em que a observadora esteve presente. 


\section{REFERÊNCIAS BIBLIOGRÁFICAS}

ABAURRE \& PONTARA. Literatura Brasileira: tempos, leitores e leituras. São Paulo: Moderna, 2011. p.539.

ANDREOTI, Azilde. O Jornal a Primeira Infância. São Paulo: Paco Editorial, 2015. p.163

ANTUNES apud MACEDO, L. Ensaio Pedagógico: Como cosntruir uma escola para todos? Porto Alegre: Artmed, 2005. p.169

ARIÈS \& DUBY. História da vida privada, Volume 5. São Paulo: Companhia das letras, 2009. p.53.

ARIÈS \& DUBY (Org.). PROST, A. História da vida privada, Volume 5. São Paulo: Companhia das letras, 2009. p.15.

ARIÈS, Philippe. História social da criança e da família. São Paulo: LCT, 1981.p.11.

ARIÈS apud POSTMAN, N. O desaparecimento da Infância. Rio de Janeiro: Graphia, 1999. p.28.

ASSIS, L. Bibliotecas Públicas e Políticas Culturais: A Divisão de Bibliotecas do Departamento de Cultura e Recreação da Prefeitura de São Paulo (1935). 2013. 139 f. Dissertação (Mestrado em Ciência da Informação, Universidade de São Paulo, São Paulo. 2013.

Associação Brasileira de Normas Técnicas. NBR 14006:

Mobiliário Escolar. 1997

BRUNER, Jerome. Atos de Significação. Artes Médicas, 1997 
CAMPELLO, Bernadete. A Biblioteca escolar, temas para uma prática pedagógica. Belo Horizonte: Autêntica, 2008. p.9.

CÂNDIDO, A. (prefácio) DUARTE, Paulo. Mário de Andrade por ele mesmo. São Paulo: HUCITEC, 1985

COADIC, Yves-François. A ciência da informação. Brasília: Briquet de Lemos, 1999. p.4-9

CORSARO, William. Sociologia da Infância. Porto Alegre: Artmed, 2011.

COSTA, A. C. G. Tempo de servir: o protagonismo juvenil passo a passo; um guia para o educador. Belo Horizonte: Universidade, 2001.

DOMINGUES, 2002 apud SZMRECSÁNY. Da Sociedade Moderna a Pós-Moderna no Brasil: permanências e mudanças urbanas, séculos XX-XXI. São Paulo: Annablume, 2011. p.19.

DUARTE, Paulo. Mário de Andrade por ele mesmo. São Paulo: HUClTEC, 1985. p.6-60

EDEN, C. \& ACKERMANN, F. MAKING STRATEGY, The Journey of Strategic Management. Londres: SAGE Publications, 1998.

FERRETI, C.J.; ZIBAS, D.M.L.; TARTUCE G.L.B.P. Protagonismo juvenil na literatura especializada e na reforma do ensino médio. Cadernos de Pesquisa, v.24, n.122, p. 411- 423, São Paulo. Maio/ago.2004.

FLICK, U. Introdução à Pesquisa Qualitativa. Bookman, 2009. p.149.

FRACCAROLI, L. Biblioteca Infantil do Departamento Municipal de 
Cultura. Separata da Revista do Arquivo n.LXIV. Departamento de Cultura de São Paulo, 1940. p.293.

FREEMAN, R. Strategic Management. Cambridge: Cambridge University Press, 2010.

FREITAS, Marcos. História social da Infância no Brasil. São Paulo: Cortez, 2010.

KOSKINEN, I. \& BATTARBEE, K. Empathic Design: User Experience in ProductDesign.TheDesign Journal.Vol.7,2004.Disponívelem:<http:// www.tandfonline.com/doi/abs/10.2752/146069204789338406> Acessado em 14 de janeiro de 2016.

KOWALTOWSKI, Doris. Arquitetura escolar - o projeto do ambiente de ensino. São Paulo: Oficina de Textos, 2011.

La société de l'information: glossaire critique. Paris, 2005

LAFFITTE (1973) prefácio: ARIÈS, Philippe. História social da criança e da família. São Paulo: LCT, 1981. p.11.

Manifesto Unesco/Ifla para a Biblioteca Escolar, p. 419 apud Macedo, p. 168.

MEGGS, Philip \& PURVIS Alston. História do design gráfico. São Paulo: Cosac Naify, 2009. p.91.

MELO, M. \& NEVES, D. A Importância da Biblioteca Infantil. Biblionline, v.1, n.2, 2005. Disponível em: < http://periodicos.ufpb.br/index. php/biblio/article/view/584/422 > Acessado em 20 de novembro de 2015. 
MILANESI, L. Biblioteca. Ateliê Editorial, 2002. p.23 - 56.

MORAES, Ana \& MONT'ALVAO, Claudia. Ergonomia conceito e aplicações. Rio de Janeiro: 2AB, 2009

MORAES, Ana \& MONT'ALVAO, Claudia. Um novo olhar para o projeto. Teresópolis: 2AB, 2011

PANERO, Julius \& ZELNIK, Martin. Dimensionamento humano para espaços interiores. Barcelona: Gustavo Gili, 2002.

PERROTTI,E \& PIERRUCINI, I. Saberes e fazeres na contemporaneidade. 2007. p.53.

PIERUCCINI, IVETE. A ORDEM INFORMACIONAL DIALÓGICA: ESTUDOsobre a busca de informação em educação. São Paulo, 2004. 94f. Tese (Doutorado em Ciência da Informação, Universidade de São Paulo, São Paulo. 2004.

POSTMAN, N. O desaparecimento da Infância. Rio de Janeiro: Graphia, 1999. p.25- 59 .

REIPERT, H. História da Biblioteca Pública Municipal Mário de Andrade. 1972. p.21.

RESENDE, Haroldo. Michel Foucault - O governo da infância. Belo Horizonte: Autêntica Editora, 2015

SANTOS, Maria. Móvel Moderno no Brasil. São Paulo: Editora Olhares, 2015.

SEVCENKO, Nicolau. História da vida privada no Brasil, volume 3.São Paulo: Schwarcz, 2010 
STEINBERG, Shirley \& KINCHELOE, Joe. Cultura Infantil: A construção corporativa da infância. Rio de Janeiro: Civilização Brasileira, 2004

SZMRECSÁNY, Maria. Da Sociedade Moderna a Pós-Moderna no Brasil: permanências e mudanças urbanas, séculos XX-XXI. São Paulo: Annablume, 2011. p.25 - 27.

TARALLI, Cibele. Espaço, mobiliário e comunicação visual. São Bernardo do Campo: Cadernos REBI, 2007. p. 6 - 7

SITES

ARTRIC. Disponível em: < http://www.artriq.com.br/> Acessado em janeiro de 2017.

DESIGN BOOM. Disponível em: <http://www.designboom.com/> Acessado em fevereiro de 2017.

NIÑOS CONARTE. Disponível em: <http://www.conarte.org.mx/NINOS> Acessado em fevereiro de 2017.

DESK MÓVEIS. Disponível em: <http://www.deskmoveis.com.br/> Acessado em janeiro de 2017.

LIBRARY BUILDINGS. Disponível em: < http://www.librarybuildings. info/denmark/hjorring-library-metropol > Acessado em fevereiro de 2017.(último acesso em fevereiro de 2017)

LINEA RICA. Disponível em: < http://linearica.com.br/> Acessado em janeiro de 2017.

METADIL. Disponível em: <http://www.metadil.com.br/> Acessado 
em janeiro de 2017.

MOVESCO. Disponível em: <http://www.movesco.com.br/> Acessado em janeiro de 2017.

MÓVEL ESCOLAR. Disponível em: <http://www.movelescolar.ind. $\mathrm{br} />$ Acessado em janeiro de 2017.

NOVIDÁRIO. Disponível em: <http://www.novidario.com.br/> Acessado em janeiro de 2017.

OMEGA DESIGN. Disponível em: <http://www.omegadesign.com. br/> Acessado em janeiro de 2017. 


$$
\text { APENDICE }
$$




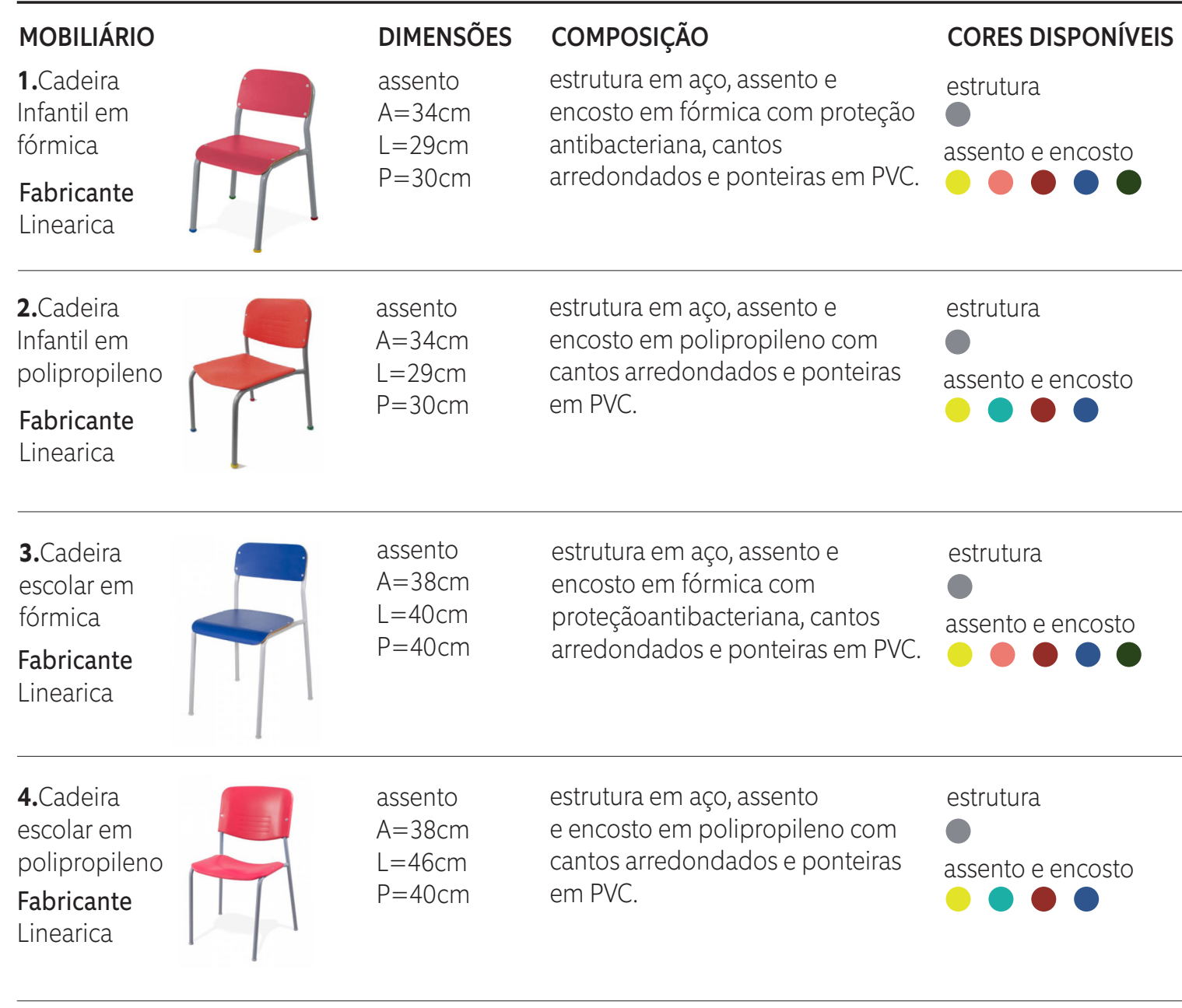

\section{Cadeira fixa} infantil

Fabricante Artric

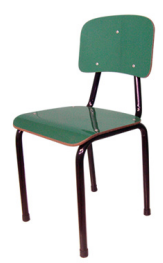

estrutura em tubo redondo com encosto e assento revestido em fórmica estrutura

assento e encosto

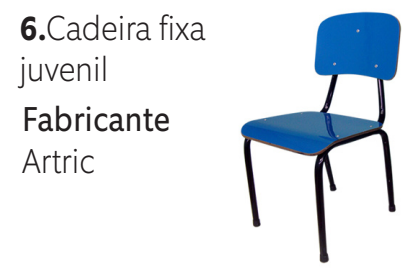

6. Cadeira fixa juvenil

Fabricante Artric

7. Cadeira fixa
juvenil
Fabricante
Artric

estrutura em tubo redondo com encosto e assento revestido em fórmica estrutura

O

assento e encosto estrutura em tubo redondo com encosto e assento revestido em fórmica estrutura

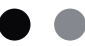

assento e encosto 


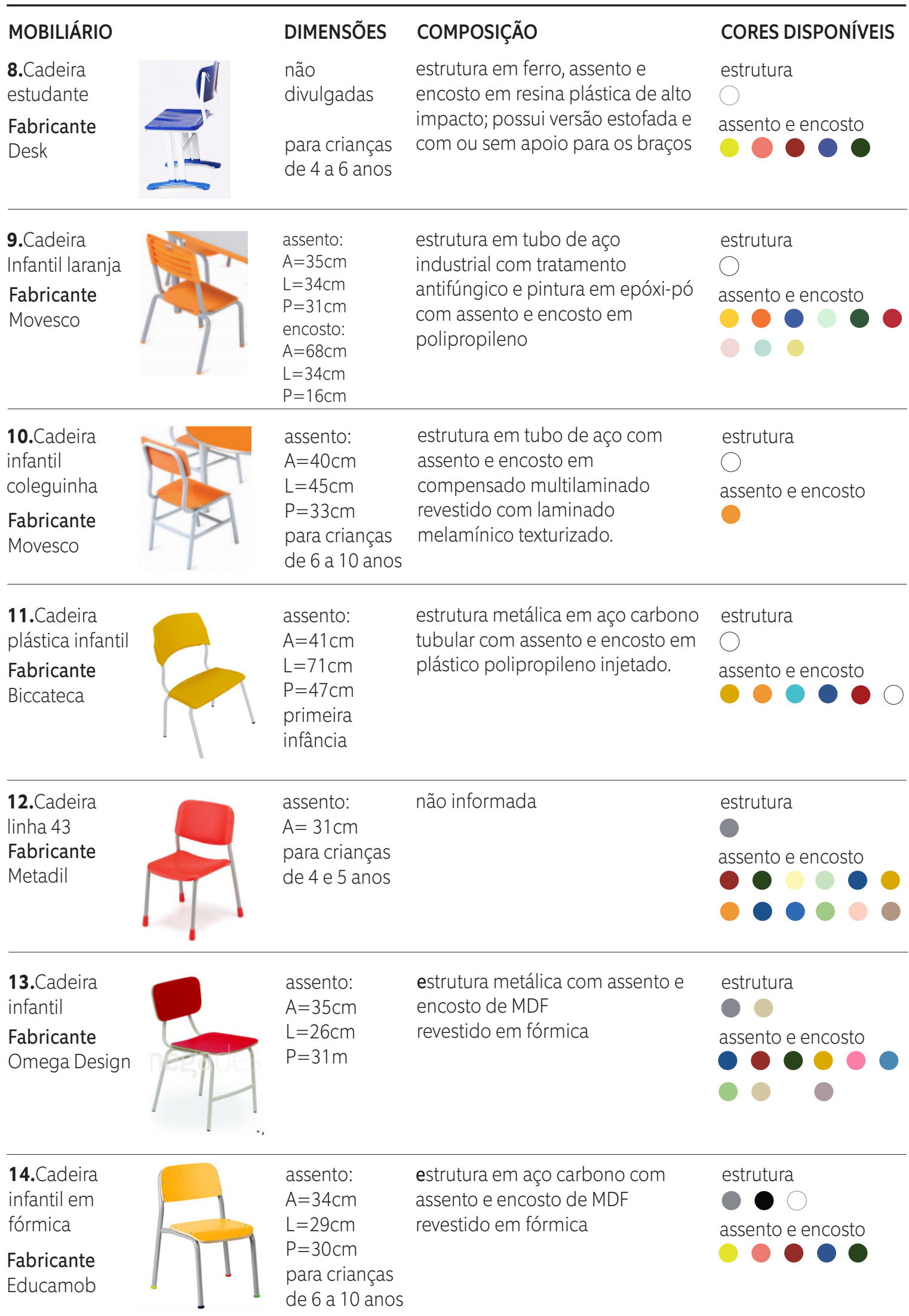




\section{MOBILIÁRIO}

15. Cadeira infantil

Fabricante

Novidário

\section{DIMENSÕES COMPOSIÇÃO}

não

divulgadas

para crianças

do ensino

infantil

madeira

\section{CORES DISPONÍVEIS}

estrutura

assento e encosto

\begin{tabular}{lllll} 
16.Estantes & & $\mathrm{L}=90 \mathrm{~cm}$ & estrutura e prateleiras em MDP e & estrutura \\
biblioteca & $\mathrm{P}=35 \mathrm{~cm}$ & base metálica com acabamento & 0 \\
Fabricante & $\mathrm{A}=40,100$, & em pintura epóxi & \\
\hline Linearica & 140,180 ou & & prateleiras \\
& $210 \mathrm{~cm}$ & & 0 \\
\hline
\end{tabular}

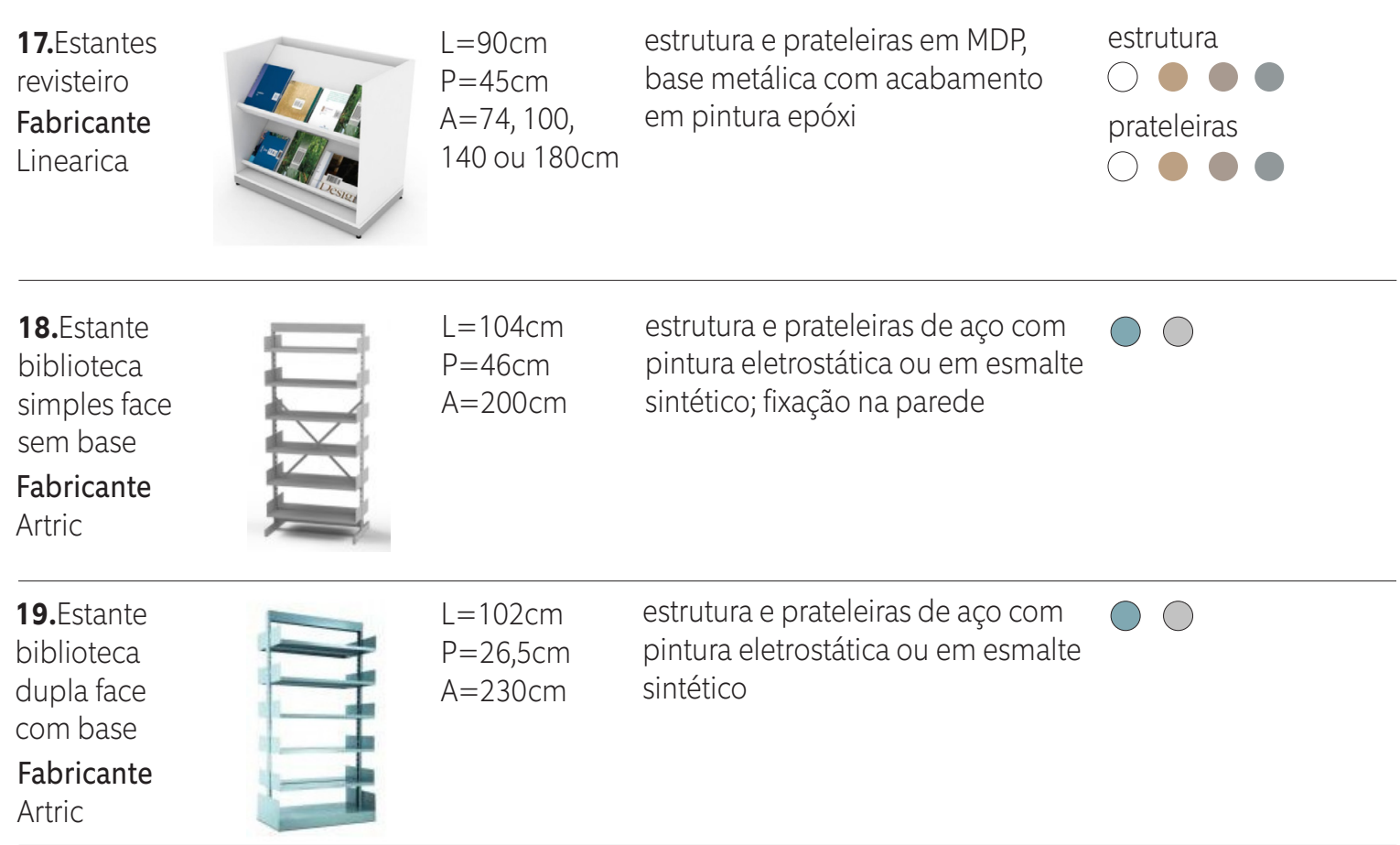

20.Estante de livros fundamental

Fabricante Educamob

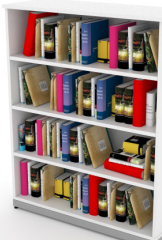

21. Revisteiro fundamental

Fabricante Educamob 


MOBILIÁRIO
22.Estante
infantil I
Fabricante
Desk

DIMENSÕES COMPOSIÇÃO

CORES DISPONÍVEIS

23. Estante de aço para biblioteca

Fabricante Movesco
$A=198 \mathrm{~cm} \quad$ estrutura e prateleiras em chapa de estrutura $L=92 \mathrm{~cm} \quad$ aço com doze prateleiras

$\mathrm{P}=58 \mathrm{~cm}$ prateleiras

0

24. Estante de aço simples arco-íris

Fabricante Movesco
$A=142 \mathrm{~cm}$

$\mathrm{L}=102 \mathrm{~cm}$

$\mathrm{P}=33 \mathrm{~cm}$ estrutura e prateleiras em chapa de estrutura aço com pintura em epóxi pó
25.Armário múltiplo uso colorido

Fabricante Movesco

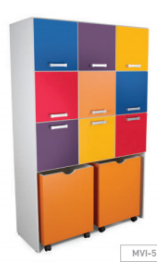

$A=190 \mathrm{~cm}$

$\mathrm{L}=120 \mathrm{~cm}$

$\mathrm{P}=45 \mathrm{~cm}$ estrutura em MDF revestido em melamínico branco, com 9 portas revestidas em melamínico colorido com puxadores; gavetões com rodízio, revestidos em melamínico estrutura

portas

gavetões
26. Armário com 2 portas coloridas

Fabricante Movesco
$\mathrm{A}=120 \mathrm{~cm}$

$\mathrm{L}=120 \mathrm{~cm}$

$\mathrm{P}=45 \mathrm{~cm}$ estrutura em MDF revestido em melamínico branco, com 9 portas revestidas em melamínico colorido com puxadores estrutura

portas

O

(n)




\section{MOBILIÁRIO}

28.Armário para tv e dvd

Fabricante

Movesco

\section{DIMENSÕES}

$A=210 \mathrm{~cm}$

$\mathrm{L}=104 \mathrm{~cm}$

$\mathrm{P}=64 \mathrm{~cm}$

\section{COMPOSIÇÃO}

estrutura em tubo de aço industrial com tratamento anticorrosivo, pintura epóxi pó, revestido em chapa de aglomerado texturizado

\section{CORES DISPONÍVEIS}

estrutura 


\section{MOBILIÁRIO}

36. Estante baixa slit

Fabricante

Biccateca

\section{DIMENSÕES}

$A=150 \mathrm{~cm}$

$\mathrm{L}=100 \mathrm{~cm}$

$\mathrm{P}=32 \mathrm{~cm}$

\section{COMPOSIÇÃO}

estrutura e prateleiras em aço com tratamento anti-corrosivo e fosfatizante e pintura eletrostática em pó
CORES DISPONÍVEIS

prateleiras

estrutura

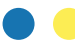

\begin{tabular}{|c|c|c|c|c|}
\hline $\begin{array}{l}\text { 37. Estante } \\
\text { organizadora } \\
\text { Fabricante }\end{array}$ & +9 & $\begin{array}{l}A=73 \mathrm{~cm} \\
L=92 \mathrm{~cm} \\
P=45 \mathrm{~cm}\end{array}$ & $\begin{array}{l}\text { estrutura em MDF com } \\
\text { revestimento em aglomerado e } \\
\text { base metálica }\end{array}$ & $\begin{array}{l}\text { base metálica } \\
\text { estrutura e prateleiras }\end{array}$ \\
\hline Metadil & $\perp a$ & & & \\
\hline
\end{tabular}

$A=99 \mathrm{~cm} \quad$ estrutura em MDF com

$L=92 \mathrm{~cm}$

revestimento em aglomerado e

base metálica

base metálica

$\mathrm{P}=45 \mathrm{~cm}$

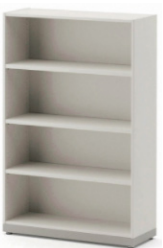

$A=142 \mathrm{~cm}$

$\mathrm{L}=92 \mathrm{~cm}$

estrutura em MDF com

prateleiras

Fabricante

Metadil revestimento em aglomerado e

base metálica base metálica

estrutura e prateleiras

\begin{tabular}{|c|c|c|c|}
\hline $\begin{array}{l}\text { 40. Expositor } \\
\text { de livros }\end{array}$ & $\begin{array}{l}A=142 \mathrm{~cm} \\
L=92 \mathrm{~cm}\end{array}$ & $\begin{array}{l}\text { estrutura em MDF com } \\
\text { revestimento em aglomerado e }\end{array}$ & base metálica \\
\hline $\begin{array}{l}\text { Fabricante } \\
\text { Metadil }\end{array}$ & $P=45 \mathrm{~cm}$ & base metálica & estrutura e prateleiras \\
\hline
\end{tabular}

41. Expositor de livros 2

Fabricante Metadil

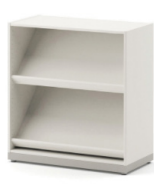

$A=106 \mathrm{~cm}$

$\mathrm{L}=92 \mathrm{~cm}$

$\mathrm{P}=45 \mathrm{~cm}$ estrutura em MDF com

revestimento em aglomerado e

base metálica base metálica

estrutura e prateleiras
42. Expositor de revistas

Fabricante

Omega

Design
$A=120 \mathrm{~cm} \quad$ estrutura em MDF revestido em

$\mathrm{L}=90 \mathrm{~cm} \quad$ aglomerado

$\mathrm{P}=36 \mathrm{~cm}$

estrutura e prateleiras

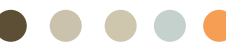




\section{MOBILIÁRIO}

43. Expositor de livros

Fabricante

Omega

Design

\section{DIMENSÕES COMPOSIÇÃO}

$\mathrm{A}=120 \mathrm{~cm}$

$\mathrm{L}=90 \mathrm{~cm}$

$\mathrm{P}=36 \mathrm{~cm}$

aglomerado
CORES DISPONÍVEIS

estrutura e prateleiras

estrutura em MDF revestido em
44. Estante infantil 2

Fabricante

Desk

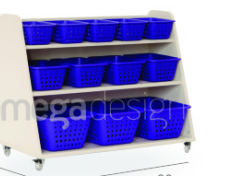

$A=75 \mathrm{~cm}$

$\mathrm{L}=90 \mathrm{~cm}$

$\mathrm{P}=45 \mathrm{~cm}$ estrutura em MDF revestido em aglomerado estrutura e prateleiras

$\bigcirc \bigcirc 00$
45. Expositor de livros

Fabricante

Novidário

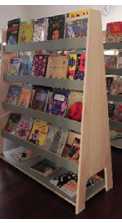

estrutura

prateleiras
46. Expositor de livros 2

Fabricante

Novidário

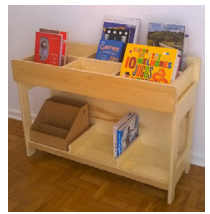

estrutura
47. Mesa colaborativa centopéia

\section{Fabricante} Linearica

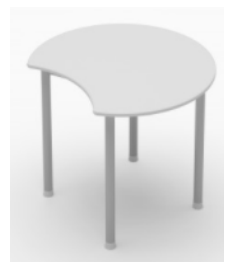
modelo 1:
tampo em MDP revestido com
estrutura
$\mathrm{A}=64 \mathrm{~cm}$
$\mathrm{L}=90 \mathrm{~cm}$
modelo 2:
$\mathrm{A}=44 \mathrm{~cm}$
$\mathrm{L}=170 \mathrm{~cm}$
$\mathrm{P}=60 \mathrm{~cm}$
laminado melamínico brilhante de alta pressão; ponteiras e acaba- mentos da estrutura em PVC, estru- tura em aço com pintura epóx
tampo
48. Mesa colaborativa meia lua
Fabricante Linearica

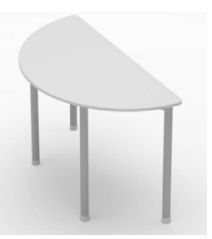
$\mathrm{A}=64 \mathrm{~cm}$
tampo em MDP revestido com
estrutura
$\mathrm{L}=120 \mathrm{~cm}$ laminado melamínico brilhante de alta pressão; ponteiras e acaba- mentos da estrutura em PVC, estru- tura em aço com pintura epóx

49.Mesa colaborativa meia lua 150 Fabricante Linearica

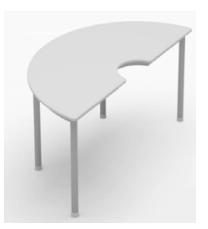

$A=64 \mathrm{~cm}$

tampo em MDP revestido com laminado melamínico brilhante de alta pressão; ponteiras e acabamentos da estrutura em PVC, estrutura em aço com pintura epóx estrutura

tampo 


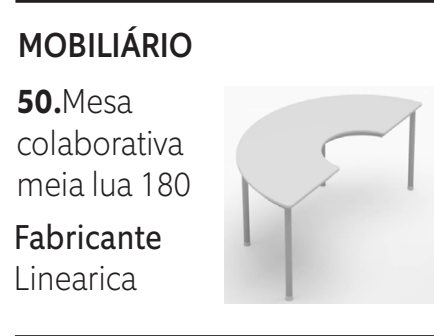

51.Mesa colaborativa retangular Fabricante Linearica

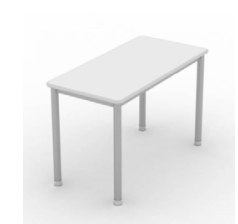

modelo 1

$\mathrm{A}=64 \mathrm{~cm}$

$\mathrm{L}=90 \mathrm{~cm}$

modelo 2 :

$\mathrm{A}=44 \mathrm{~cm}$

$\mathrm{L}=170 \mathrm{~cm}$

$\mathrm{P}=60 \mathrm{~cm}$

52.Mesa
colaborativa
trapézio
curva
Fabricante
Linearica

modelo 1:

$\mathrm{A}=64 \mathrm{~cm}$

$\mathrm{L}=90 \mathrm{~cm}$

modelo 2:

$\mathrm{A}=44 \mathrm{~cm}$

$\mathrm{L}=170 \mathrm{~cm}$

$\mathrm{P}=60 \mathrm{~cm}$

53.Mesa
Colaborativa
Triangular
Fabricante
Linearica

modelo 1:

$A=64 \mathrm{~cm}$

$\mathrm{L}=60 \mathrm{~cm}$

$\mathrm{P}=60 \mathrm{~cm}$

modelo 2:

$\mathrm{A}=44 \mathrm{~cm}$

$\mathrm{L}=170 \mathrm{~cm}$

$\mathrm{P}=60 \mathrm{~cm}$

\section{CORES DISPONÍVEIS}

tampo em MDP revestido com lam- estrutura inado melamínico brilhante de alta pressão; ponteiras e acabamentos da estrutura em PVC, estrutura em aço com pintura epóx tampo

\section{tampo em MDP revestido com lam- estrutura} inado melamínico brilhante de alta pressão; ponteiras e acabamentos da estrutura em PVC, estrutura em aço com pintura epóx tampo modelo 1:

$\mathrm{A}=64 \mathrm{~cm}$

$\mathrm{L}=60 \mathrm{~cm}$

$\mathrm{P}=60 \mathrm{~cm}$

modelo 2:

$\mathrm{A}=64 \mathrm{~cm}$

$\mathrm{L}=90 \mathrm{~cm}$

$\mathrm{P}=90 \mathrm{~cm}$ estrutura

tampo em MDP revestido com laminado melamínico brilhante de alta pressão; ponteiras e acabamentos da estrutura em PVC, estrutura em aço com pintura epóx

tampo

tampo em MDP revestido com lam- estrutura inado melamínico brilhante de alta pressão; ponteiras e acabamentos da estrutura em PVC, estrutura em tampo aço com pintura epóx

tampo em MDP revestido com laminado melamínico brilhante de alta pressão; ponteiras e acabamentos da estrutura em PVC, estrutura em tampo aço com pintura epóx

\section{Linearica}

\section{$A=64 \mathrm{~cm}$} $\mathrm{L}=120 \mathrm{~cm}$ tampo em MDP revestido com lam- estrutura inado melamínico brilhante de alta pressão; ponteiras e acabamentos da estrutura em PVC, estrutura em aço com pintura epóx
Fabricante Linearica

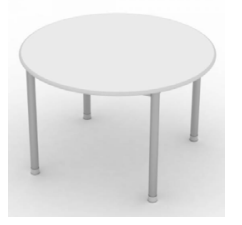

56.Mesa coletiva sextavada Fabricante Linearica

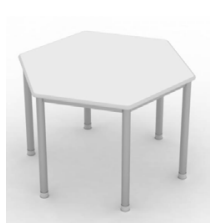

$A=64 \mathrm{~cm}$

$\mathrm{L}=120 \mathrm{~cm}$ tampo em MDP revestido com lam- estrutura inado melamínico brilhante de alta pressão; ponteiras e acabamentos da estrutura em PVC, estrutura em tampo aço com pintura epóx 


\begin{tabular}{lll}
\hline $\begin{array}{l}\text { MOBILIÁRIO } \\
\text { 57.Mesa de } \\
\text { leitura infantil } \\
\begin{array}{l}\text { Fabricante } \\
\text { Artric }\end{array}\end{array}$ & $\begin{array}{l}\text { DIMENSÕES } \\
\mathrm{A}=40 \mathrm{~cm} \\
\mathrm{~L}=100 \mathrm{~cm}\end{array}$ & $\begin{array}{l}\text { COMPOSIÇÃO } \\
\text { tampo revestido em fórmica e } \\
\text { estrutura tubular }\end{array}$
\end{tabular}

59.Mesa escolar coletiva quadrada

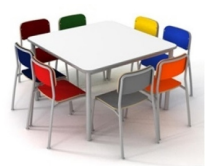

$\mathrm{L}=60 \times 60 \mathrm{~cm}$

ou $90 \times 90 \mathrm{~cm}$

ou $120 \times 120 \mathrm{~cm}$

Fabricante

Educamob

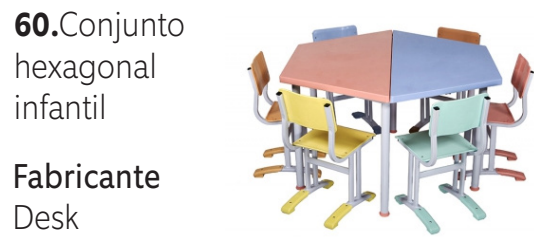

Mesa hexagonal com tampo em resina plástica de alto impacto e 6 cadeiras com assento e encosto em resina de alto impacto.

61.Conjunto coletivo bitrapézio

Fabricante Desk

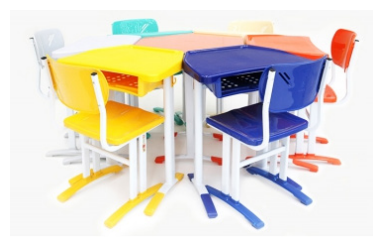

conjunto em resina plástica de alto impacto, com porta mochila e porta livros fechado no fundo e nas laterais.
62. Conjunto coletivo coleguinha

Fabricante Movesco

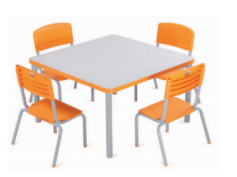

mesa: $A=58 \mathrm{~cm}$ $\mathrm{L}=100 \mathrm{~cm}$ mesa: estrutura em tubo de aço em forma de requadro; tampo em MDF revestido com laminado melamínico; bordas em alumínio tipo "T" boleado e liso estrutura da mesa

tampo

bordas da mesa
63. Conjunto coletivo infantil Fabricante Movesco

\section{mesa:}

$\mathrm{A}=46 \mathrm{~cm}$

$\mathrm{L}=80 \times 80 \mathrm{~cm}$ mesa: estrutura em tubo de aço industrial com pintura em epóxi pó;tampo em MDP ou MDF revestido em laminado melamínico fixado por parafusos estrutura da mesa

tampo da mesa 


\begin{tabular}{|c|c|c|c|c|}
\hline MOBILIÁRIO & & DIMENSÕES & COMPOSIÇÃO & CORES DISPONIIVEIS \\
\hline $\begin{array}{l}\text { 64.Conjunto } \\
\text { coletivo } \\
\text { arco-íris }\end{array}$ & $\begin{array}{l}\text { Fabricante } \\
\text { Movesco }\end{array}$ & $\begin{array}{l}\text { tampo da } \\
\text { mesa: } \\
D=40,3 \mathrm{~cm} \\
A=58 \mathrm{~cm} \\
\text { cadeira: } \\
\text { assento: } \\
A=34 \mathrm{~cm} \\
L=30,5 \mathrm{~cm} \\
P=29,5 \mathrm{~cm} \\
\text { encosto: } \\
A=62,5 \mathrm{~cm} \\
L=30 \mathrm{~cm} \\
P=18 \mathrm{~cm}\end{array}$ & $\begin{array}{l}\text { mesa: estrutura, haste central e } \\
\text { base dos pés em tubo, ponteiras } \\
\text { em resina plástica; tampo em } \\
\text { resina plástica de alto impacto com } \\
\text { recorte sextavado. } \\
\text { cadeira: estrutura em tubo, protetor } \\
\text { de pintura com formato de "U” em } \\
\text { resina plástica. Porta livros, painéis } \\
\text { frontal e laterais em resina plástica } \\
\text { de alto impacto. }\end{array}$ & $\begin{array}{l}\text { estrutura } \\
\text { resina }\end{array}$ \\
\hline $\begin{array}{l}\text { 65.Conjunto } \\
\text { coletivo } \\
\text { girassol }\end{array}$ & $\begin{array}{l}\text { Fabricante } \\
\text { Movesco }\end{array}$ & $\begin{array}{l}\text { tampo da mesa: } \\
d=87 \mathrm{~cm} \\
a=58 \mathrm{~cm} \\
\text { cadeira: } \\
\text { assento: } \\
A=35 \mathrm{~cm} \\
L=31 \mathrm{~cm} \\
P=34 \mathrm{~cm} \\
\text { encosto: } \\
A=68 \mathrm{~cm} \\
L=34 \mathrm{~cm} \\
P=16 \mathrm{~cm}\end{array}$ & $\begin{array}{l}\text { mesa: estrutura em tubo, ponteiras } \\
\text { em polipropileno. tampo em MDF } \\
\text { revestido em melamínico, bordas } \\
\text { boleadas com acabamento em } \\
\text { verniz } \\
\text { cadeiras: estrutura em tubo com } \\
\text { quatro travessas entre as pernas } \\
\text { em tubo. topos com ponteiras em } \\
\text { polipropileno. assento e encosto } \\
\text { em compensado multilaminado } \\
\text { revestido com laminado melamíni- } \\
\text { co texturizado. tratamento anticor- } \\
\text { rosivo e pintura em epóxi-pó. }\end{array}$ & $\begin{array}{l}\text { estrutura } \\
\text { compensado e PP }\end{array}$ \\
\hline $\begin{array}{l}\text { 66.Conjunto } \\
\text { coletivo } \\
\text { primavera }\end{array}$ & $\begin{array}{l}\text { Fabricante } \\
\text { Movesco }\end{array}$ & $\begin{array}{l}\text { tampo da } \\
\text { mesa: } \\
D=98 \mathrm{~cm} \\
A=58 \mathrm{~cm} \\
\text { cadeiras: } \\
\text { assento: } \\
A=34 \mathrm{~cm} \\
L=34 \mathrm{~cm} \\
P=33 \mathrm{~cm} \\
\text { encosto: } \\
A=62,5 \mathrm{~cm} \\
L=33 \mathrm{~cm} \\
P=18 \mathrm{~cm}\end{array}$ & $\begin{array}{l}\text { mesa: estrutura em tubos, pon- } \\
\text { teiras em polipropileno. tampo } \\
\text { em compensado revestido em } \\
\text { laminado melamínico com bordas } \\
\text { em verniz. fixado por parafusos } \\
\text { cadeiras: estrutura e base do } \\
\text { encostoem tubo, ponteiras em } \\
\text { polipropileno. assento e encosto } \\
\text { em resina plástica de alto impacto. } \\
\text { tratamento anticorrosivo e pintura } \\
\text { epóxi-pó. }\end{array}$ & $\begin{array}{l}\text { estrutura } \\
\text { resina }\end{array}$ \\
\hline
\end{tabular}




\section{MOBILIÁRIO}

67. Conjunto coletivo coração

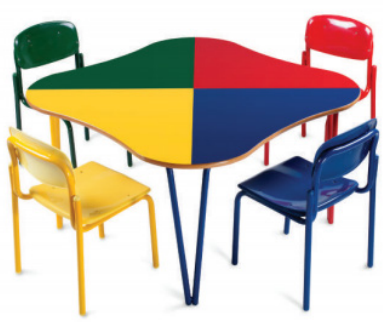

\section{DIMENSÕES COMPOSIÇÃO}

tampo da mesa: mesa: estrutura em tubo em for$\mathrm{L}=80 \mathrm{~cm} x$ $80 \mathrm{~cm}$

$A=58 \mathrm{~cm}$

cadeiras:

assento:

$\mathrm{A}=34 \mathrm{~cm}$

$\mathrm{L}=34 \mathrm{~cm}$

$\mathrm{P}=33 \mathrm{~cm}$

encosto:

$A=62,5 \mathrm{~cm}$

$\mathrm{L}=33 \mathrm{~cm}$

$\mathrm{P}=18 \mathrm{~cm}$ mato de "V", ponteira em polipropileno. tampo em MDF revestido em melamínico em 4 cores, bordas boleadas com acabamento em verniz

cadeiras: estrutura em tubo, ponteiras em polipropileno. assento e encosto em resina plástica PP de alto impacto, alto brilho, anatômico e abas laterais. tratamento anticorrosivo e pintura epóxi-pó.

\section{CORES DISPONÍVEIS}

estrutura

\section{tampo}

\section{Conjunto Fabricante} coletivo 4 cores

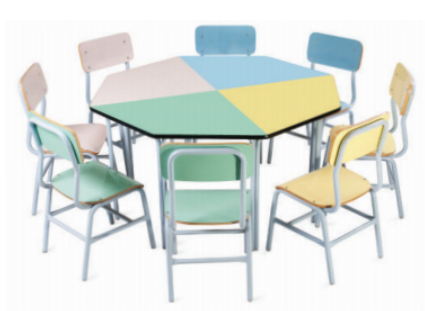

tampo da mesa:

$D=120 \mathrm{~cm}$

$A=58 \mathrm{~cm}$

cadeiras:

assento:

$A=35 \mathrm{~cm}$

$\mathrm{L}=34 \mathrm{~cm}$

$\mathrm{P}=31 \mathrm{~cm}$

encosto:

$\mathrm{A}=68 \mathrm{~cm}$

$\mathrm{L}=34 \mathrm{~cm}$

$\mathrm{P}=16 \mathrm{~cm}$ mesa: estrutura em forma de " $U$ " invertido, pés com ponteiras plásticas; tampo em MDF revestido com laminado melamínico, bordas com perfil PVC

cadeiras: estrutura e travessa entre as pernas em tubo, topos com ponteiras em polipropileno. assento e encosto em compensado multilaminado revestido com laminado melamínico texturizado. ratamento anticorrosivo e pintura epóxi-pó. estrutura

f'órmica

\section{Mesa}

infantil folha, borboleta ou flor

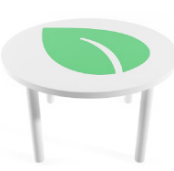

$A=52 \mathrm{~cm}$

$\mathrm{L}=95 \mathrm{~cm}$

$\mathrm{P}=95 \mathrm{~cm}$

Fabricante Biccateca

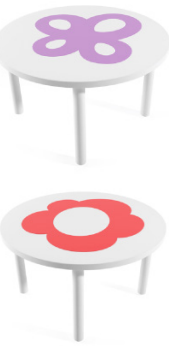

estrutura em aço, tampo em MDF e desenho central em adesivo de alta resistência estrutura da mesa

tampo

adesivos

folha

borboleta

flor 


\begin{tabular}{|c|c|c|c|}
\hline $\begin{array}{l}\text { MOBILIÁRIO } \\
\text { 70.Mesa de } \\
\text { informática } \\
\text { infantil } 1 \\
\text { Fabricante } \\
\text { Metadil }\end{array}$ & $\begin{array}{l}\text { DIMENSÕES } \\
\text { tampo } \\
\begin{array}{l}A=53 \mathrm{~cm} \\
L=70 \mathrm{~cm} \\
P=60 \mathrm{~cm}\end{array}\end{array}$ & $\begin{array}{l}\text { COMPOSIÇÃO } \\
\text { estrutura e tampo em MDP } \\
\text { revestido com laminado } \\
\text { melamínico brilhante }\end{array}$ & $\begin{array}{l}\text { CORES DISPONÍVEIS } \\
\text { estrutura } \\
\text { tampo }\end{array}$ \\
\hline $\begin{array}{l}\text { 71.Mesa de } \\
\text { informática } \\
\text { infantil } 2 \\
\text { Fabricante } \\
\text { Metadil }\end{array}$ & $\begin{array}{l}A=74 \mathrm{~cm} \\
L=80 \times 80 \mathrm{~cm}\end{array}$ & $\begin{array}{l}\text { estrutura metálica com tampo em } \\
\text { MDP revestido com laminado } \\
\text { melamínico brilhante }\end{array}$ & $\begin{array}{l}\text { estrutura } \\
\text { tampo }\end{array}$ \\
\hline $\begin{array}{l}\text { 72.Mesa } \\
\text { retangular } \\
\text { Fabricante } \\
\text { Metadil }\end{array}$ & $\begin{array}{l}\text { A1 }=59 \mathrm{~cm} \\
(6-7 \text { anos }) \\
\text { A2 }=64 \mathrm{~cm} \\
\text { (8-10anos) } \\
\text { Le P depedem } \\
\text { da quantidade } \\
\text { de lugares } \\
\text { desejada }\end{array}$ & $\begin{array}{l}\text { estrutura metálica com tampo em } \\
\text { MDP revestido com laminado } \\
\text { melamínico brilhante }\end{array}$ & $\begin{array}{l}\text { estrutura } \\
\text { tampo }\end{array}$ \\
\hline $\begin{array}{l}\text { 73.Mesa } \\
\text { quadrada } \\
\text { Fabricante } \\
\text { Metadil }\end{array}$ & $\begin{array}{l}\mathrm{A} 1=59 \mathrm{~cm} \\
(6-7 \text { anos }) \\
\mathrm{A} 2=64 \mathrm{~cm} \\
(8-10 \mathrm{anos}) \\
\mathrm{L}=90 \mathrm{~cm} \times 90 \mathrm{~cm}\end{array}$ & $\begin{array}{l}\text { estrutura metálica com tampo em } \\
\text { MDP revestido com laminado } \\
\text { melamínico brilhante }\end{array}$ & $\begin{array}{l}\text { estrutura } \\
\text { tampo }\end{array}$ \\
\hline
\end{tabular}

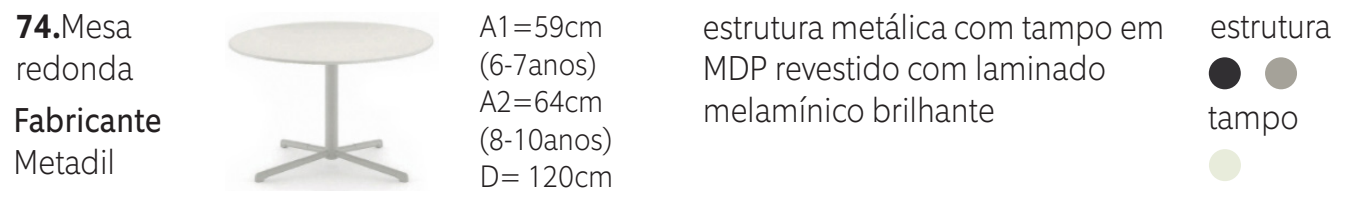

75. Mesa circular

Fabricante Metadil
$A 1=59 \mathrm{~cm}$

(6-7anos)

$\mathrm{A} 2=64 \mathrm{~cm}$

(8-10anos)

$\mathrm{D}=120 \mathrm{~cm}$ estrutura metálica com tampo em MDP revestido com laminado melamínico brilhante

estrutura

O

tampo
76. Mesa meia circular

Fabricante Metadil
$\mathrm{A} 1=59 \mathrm{~cm}$

(6-7anos)

$\mathrm{A} 2=64 \mathrm{~cm}$

(8-10anos)

$\mathrm{L}=120 \mathrm{~cm}$

$\mathrm{P}=60 \mathrm{~cm}$ estrutura metálica com tampo em

estrutura MDP revestido com laminado melamínico brilhante 
MOBILIÁRIO

77.Mesa meia lua

Fabricante

Metadil

\section{DIMENSÕES}

tampo:

$\mathrm{A}=53 \mathrm{~cm}$

$\mathrm{L}=150 \mathrm{~cm}$

$\mathrm{P}=75 \mathrm{~cm}$
COMPOSIÇÃO

estrutura metálica com tampo em

MDP revestido com laminado

melamínico brilhante

tampo

\section{CORES DISPONIIVEIS}

estrutura
78. Mesa hexagonal

Fabricante

Metadil

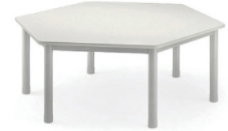

$\mathrm{A} 1=59 \mathrm{~cm}$

(6-7anos)

$\mathrm{A} 2=64 \mathrm{~cm}$

(8-10anos)

$D=135 \mathrm{~cm}$ estrutura metálica com tampo em

MDP revestido com laminado

melamínico brilhante

estrutura

tampo
79.Mesa trapezoidal

Fabricante

Metadil
$\mathrm{A} 1=59 \mathrm{~cm}$

(6-7anos)

$\mathrm{A} 2=64 \mathrm{~cm}$

(8-10anos)

$L=140 \mathrm{~cm}$

$\mathrm{P}=70 \mathrm{~cm}$ estrutura metálica com tampo em estrutura MDP revestido com laminado melamínico brilhante

tampo
$\mathrm{A}=46 \mathrm{~cm}$ ou

$53 \mathrm{~cm}$ ou $59 \mathrm{~cm}$

$\mathrm{L}=80 \mathrm{~cm}$ estrutura metálica com tampo em

MDF

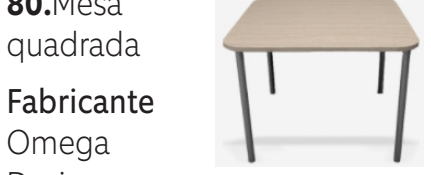

Design
$\mathrm{A}=46 \mathrm{~cm}$ ou

$53 \mathrm{~cm}$ ou $59 \mathrm{~cm}$

$\mathrm{D}=90 \mathrm{~cm}$ estrutura metálica com tampo em

estrutura

MDF redonda

Fabricante

Omega

Design

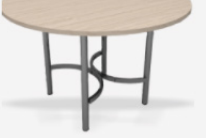

tampo

tampo
82. Mesa

meia lua

Fabricante

Omega

Design
$\mathrm{A}=46 \mathrm{~cm}$ ou

$53 \mathrm{~cm}$ ou $59 \mathrm{~cm}$

$\mathrm{D}=120 \mathrm{~cm}$ estrutura metálica com tampo em

estrutura

MDF

tampo 
QUADRO 0.0

COMPILAÇÃO DE MOBILIÁRIO OFERTADO PELA INDÚSTRIA E POR ESCRITÓRIOS DE DESIGN

MOBILIÁRIO

84. Mesa retangular

Fabricante

Omega

Design

\section{DIMENSÕES COMPOSIÇÃO}

$\mathrm{A}=46 \mathrm{~cm}$ ou

$53 \mathrm{~cm}$ ou $59 \mathrm{~cm}$

$\mathrm{L}=120 \mathrm{~cm}$

ou $160 \mathrm{~cm}$ ou

$200 \mathrm{~cm}$

$\mathrm{P}=80 \mathrm{~cm}$ MDF
CORES DISPONÍVEIS

estrutura metálica com tampo em

estrutura

tampo

(2)

85. Mesa

Fabricante

Novidário

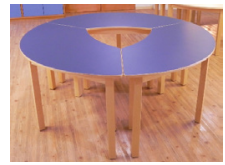

86. Mesa

Fabricante

Novidário

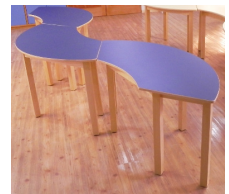

87. Mesa

Fabricante

Novidário

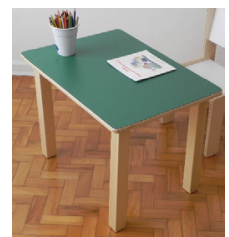

88. Expositor

Fabricante

Novidário

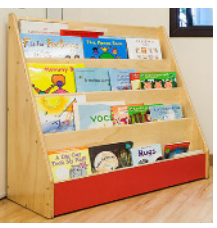

89. Expositor

Fabricante

Novidário

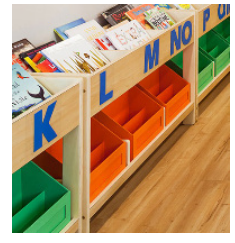

90. Call center infantil

Fabricante

Linearica

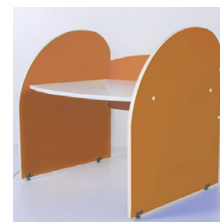

$A=52 \mathrm{~cm}$

$\mathrm{L}=96 \mathrm{~cm}$

$\mathrm{P}=74 \mathrm{~cm}$ tampo e laterais em MDP

laterais

tampo 


\section{MOBILIÁRIO}

91. Carrinho multimídia

Fabricante

Metadil

\section{DIMENSÕES COMPOSIÇÃO}

$A=110 \mathrm{~cm}$

$\mathrm{L}=84,5 \mathrm{~cm}$

$\mathrm{P}=50 \mathrm{~cm}$

\section{CORES DISPONÍVEIS}

estrutura metálica com prateleiras e laterais em MDP, possui rodízios

estrutura

prateleiras e laterais

\section{Placas} para sentar

Fabricante

Desk

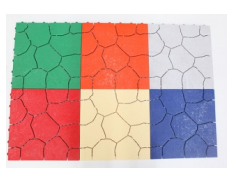

$\mathrm{L}=30 \mathrm{~cm} \times 30 \mathrm{~cm}$ placas acopladas, fabricadas em resina plástica de alto impacto placas

1000
93. Carrinho ergonômico

Fabricante Biccateca

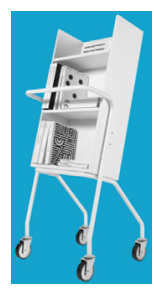

$A=144 \mathrm{~cm}$

$\mathrm{L}=59,5 \mathrm{~cm}$

$\mathrm{P}=57 \mathrm{~cm}$ estrututura e prateleira em aço,

com tratamento anti-corrosivo e

fosfatizante, corpo em MDF estrutura e prateleiras

corpo
94. Escada biblioteca duraline Fabricante Biccateca
$\mathrm{A}=40 \mathrm{~cm}$

$\mathrm{L}=35 \mathrm{~cm}$

$\mathrm{P}=42 \mathrm{~cm}$ aço com pintura eletrostática a pó, tratamento anti-corrosivo e fosfatizante estrutura

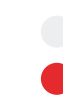

95. Carrinho biblioteca slit Fabricante Biccateca

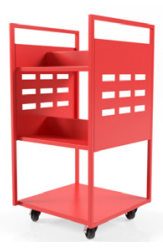

$\mathrm{A}=105 \mathrm{~cm}$

$\mathrm{L}=53 \mathrm{~cm}$

$\mathrm{P}=53 \mathrm{~cm}$ aço com pintura eletrostática a pó, tratamento anti-corrosivo e fosfatizante estrutura

0
96. Carrinho para livros e brinquedos

Fabricante Metadil

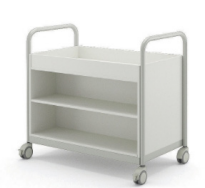

$A=101 \mathrm{~cm}$
$\mathrm{L}=110 \mathrm{~cm}$

estrutura metálica com prateleiras

e laterais em MDP

estrutura

$\mathrm{P}=60 \mathrm{~cm}$ tampo
97.Box brinquedo

Fabricante Omega Design

$A=45 \mathrm{~cm} \quad$ em painel de MDF
$L=45 \mathrm{~cm}$
$P=45 \mathrm{~cm}$

$\mathrm{A}=45 \mathrm{~cm}$

$\mathrm{P}=45 \mathrm{~cm}$ estrutura

\section{OP}


São Paulo, 1 de novembro de 2016

Prezada(o),

Olá! Me chamo Aline e sou aluna do Programa de Mestrado da Faculdade de Arquitetura e Urbanismo da USP. Minha pesquisa se propõe a analisar bibliotecas infantis (públicas e escolares), e como crianças entre 6 e 9 anos se relacionam com estes espaços. Parte da pesquisa necessita do olhar da criança sobre o ambiente. Portanto, peço que, se possível, aplique esta atividade com a sua criança.

Instruções para a atividade:

Dê uma folha de papel sulfite em branco à criança.

Peça que ela preencha a folha com desenho (usando lápis, canetinhas,etc), colagem de recortes de revistas ou outros impressos disponíveis nas sua casa, frases ou palavras, ou até mesmo uma historinha ( pode ser com texto escrito por ela), com o seguinte tema: Eu gostaria que a biblioteca da minha escola fosse assim: Não interfira no processo criativo da criança: deixe que ela estabeleça o tempo necessário para responder a questão. Quando a criança quiser parar, pode dar a atividade por encerrada.

Depois que a atividade acabar, por favor, peça que a criança identifique os elementos que desenhou, escrevendo o(s) nome(s) das partes que compõe o desenho (ou colagem), colaborando para identificar o pensamento dela sobre este tema. Você mesmo pode escrever o que a criança falar sobre o desenho. No verso da folha, identifique a idade da criança e a série em que se encontra. Por fim, é só colocar a folha de volta na agenda para ser entregue a bibliotecária.

Muito obrigada por sua colaboração com minha pesquisa! Para qualquer esclarecimento, fique à vontade para entrar em contato pelo número (11) 98416 5510 ou via e-mail alinepessoaamorim@gmail.com

Atenciosamente,

Aline Pessoa 
1. Com que frequência você visita esta biblioteca?

2. Qual seu grau de parentesco com a(s) criança(s) que você trouxe hoje?

3. Vocês moram perto daqui?

4. Porque vocês vieram visitar a Biblioteca Monteiro Lobato?

5. O que você acha que esta biblioteca tem de melhor? Qual é a sua coisa preferida aqui?

6. O que você acha que poderia ser diferente nesta biblioteca?

A pergunta a seguir é dirigida à(s) criança(s) que acompanham o adulto entrevistado, quando possível:

7. De quê você mais gosta nesta biblioteca? 

